Prepared in cooperation with the

Northeastern San Joaquin Groundwater Banking Authority and California Department of Water Resources

\title{
Groundwater Data for Selected Wells within the Eastern San Joaquin Groundwater Subbasin, California, 2003-8
}

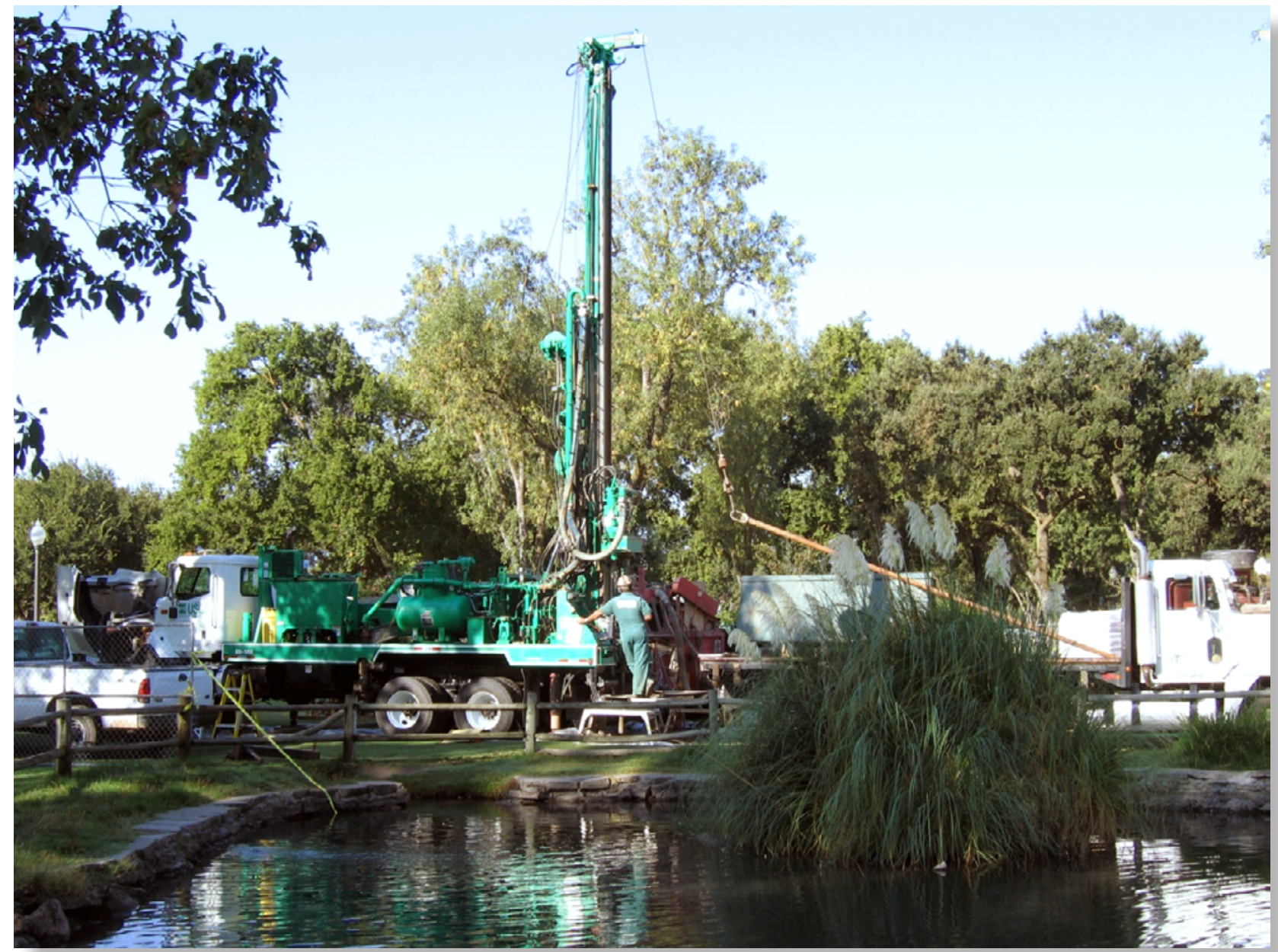

Data Series 696

U.S. Department of the Interior

U.S. Geological Survey 
Cover: Photograph of U.S. Geological Survey drill rig used to install wells 001N006E04J003M, and -04J004M at multiple-well monitoring site STK-4 in Victory

Park, Stockton, California, September 12, 2005. Photograph taken by Rhett Everett, U.S.

Geological Survey, 2005. 


\section{Groundwater Data for Selected Wells within the Eastern San Joaquin Groundwater Subbasin, California, 2003-8}

By Dennis A. Clark, John A. Izbicki, Loren F. Metzger, Rhett R. Everett, Gregory A. Smith, David O'Leary, Nicholas F. Teague, and Matthew K. Burgess

Prepared in cooperation with the Northeastern San Joaquin Groundwater Banking Authority and the California Department of Water Resources

Data Series 696 


\title{
U.S. Department of the Interior \\ KEN SALAZAR, Secretary \\ U.S. Geological Survey \\ Marcia K. McNutt, Director
}

\author{
U.S. Geological Survey, Reston, Virginia: 2012
}

For more information on the USGS - the Federal source for science about the Earth, its natural and living resources, natural hazards, and the environment, visit http://www.usgs.gov or call 1-888-ASK-USGS.

For an overview of USGS information products, including maps, imagery, and publications, visit http://www.usgs.gov/pubprod

To order this and other USGS information products, visit http://store.usgs.gov

Any use of trade, product, or firm names is for descriptive purposes only and does not imply endorsement by the U.S. Government.

Although this report is in the public domain, permission must be secured from the individual copyright owners to reproduce any copyrighted materials contained within this report.

Suggested citation:

Clark, D.A., Izbicki, J.A., Metzger, L.F., Everett, R.R., Smith, G.A., O'Leary, David, Teague, N.F., and Burgess, M.K., 2012, Groundwater Data for Selected Wells within the Eastern San Joaquin Groundwater Subbasin, California, 2003-8: U.S. Geological Survey Data Series 696, 154 p. 


\section{Acknowledgments}

This study was funded by the Northeastern San Joaquin Groundwater Banking Authority (NESJGBA) and the California Department of Water Resources in cooperation with the U.S. Geological Survey. Additional funding for drilling and installation of multiple-well monitoring sites was provided by the City of Stockton. The authors thank the County of San Joaquin, the California Department of Water Resources, and the California State Water Resources Control Board Groundwater Ambient Monitoring and Assessment (GAMA) Program for their assistance with sample collection and analyses. The authors thank the board members of the NESJGBA, local water agencies, and their employees - especially Melvin Lytle and Brandon Nakagawa of San Joaquin County Public Works Department, Anthony Tovar of the City of Stockton Municipal Utilities Department, and Eric Mar of the California Water Service Company-for their support and for access to wells during this study. The authors thank Michael Infurna of the San Joaquin Department of Public Health for his advice on well design and construction as part of the permitting and inspection process. The authors thank residents and business owners who granted permission to collect water levels and water-chemistry samples from their privately owned wells.

The authors also thank Sharon Clark for assistance in preparing and editing the report and Larry Schneider for assistance with scientific illustrations. 
This page intentionally left blank. 


\section{Contents}

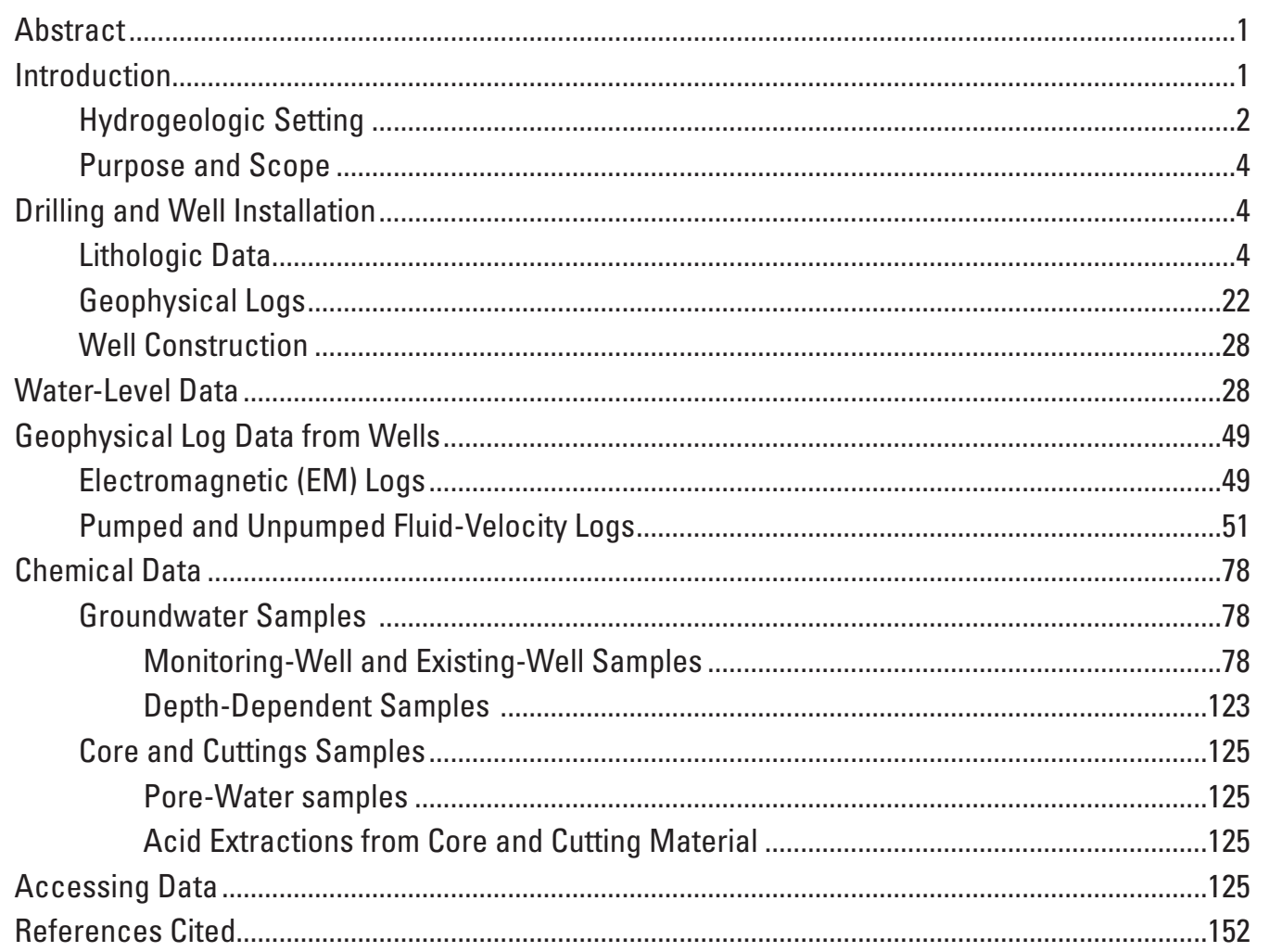




\section{Figures}

1. Map showing location of study area, Eastern San Joaquin Groundwater Subbasin, California

2. Map showing location of the multiple-well monitoring sites, Eastern San Joaquin Groundwater Subbasin, California

3. Photograph of U.S. Geological Survey drill rig used to install wells 001N006E04J003M, and -04J004M at multiple-well monitoring site STK-4 in Victory Park, Stockton, California, September 12, 2005

4. Figure showing piper diagrams of rock-type nomenclature used for description of texture in lithologic logs. Modified from Folk, 1954

5. Diagrams of geophysical logs, lithology, and construction information for multiple-well monitoring site STK-4 (wells 001N006E04J003M, -04J004M, and -04J005M), Eastern San Joaquin Groundwater Subbasin, California

6. Diagrams of geophysical logs, lithology, and construction information for multiple-well monitoring site STK-1 (wells 002N005E01A002M, -01A003M, -01A004M, -01A005M, and -01A006M), Eastern San Joaquin Groundwater Subbasin, California

7. Diagrams of geophysical logs, lithology, and construction information for multiple-well monitoring site STK-5 (wells 002N006E08N001M, -08N002M, and -08N003M), Eastern San Joaquin Groundwater Subbasin, California

8. Diagrams of geophysical logs, lithology, and construction information for multiple-well monitoring site STK-2 (wells 002N006E11H004M, -11H005M, -11H006M, -11H007M and -11H008M), Eastern San Joaquin Groundwater Subbasin, California

9. Diagrams of geophysical logs, lithology, and construction information for multiple-well monitoring site STK-6 (wells 002N006E29H001M, -29H002M, and -29H003M), Eastern San Joaquin Groundwater Subbasin, California

10. Photograph of well development using an air compressor at multiple-well monitoring site 002N006E20E001M, -20E002M, and-20E003M (Swenson Park), Stockton, California, March 27, 2007

11. Graphs showing water levels for multiple-well monitoring site STK-4 (001N006E04J003M, -04J004M, and -04J005M), Eastern San Joaquin Groundwater Subbasin, California, individual wells, and with depth.

12. Graphs showing water-level data for multiple-well monitoring site SPERRY ROAD (001N006E36C003M, -36C004M, and -36C005M), Eastern San Joaquin Groundwater Subbasin, California, individual wells, and with depth...

13. Graphs showing water levels for multiple-well monitoring site STK-1 (002N005E01A002M,-01A003M,-01A004M,-01A005M, and --01A006M), Eastern San Joaquin Groundwater Subbasin, California, individual wells, and with depth

14. Graphs showing water levels for multiple-well monitoring site STK-5 (002N006E08N001M, -08N002M, and -08N003M), Eastern San Joaquin Groundwater Subbasin, California, individual wells, and with depth...

15. Graphs showing water levels for multiple-well monitoring site STK-2 and STK-3 (002N006E11H004M,-11H005M,-11H006M,-11H007M and-11H008M), Eastern San Joaquin Groundwater Subbasin, California, individual wells, and with depth 


\section{Figures}

16. Graphs showing water levels for multiple-well monitoring site SWENSON PARK (002N006E20E001M, -20E002M, and-20E003M), Eastern San Joaquin Groundwater Subbasin, California, individual wells, and with depth.....

17. Graphs showing water levels for multiple-well monitoring site BLOSSOM RANCH (002N006E24P001M, -24P002M, and -24P003M), Eastern San Joaquin Groundwater Subbasin, California, individual wells, and with depth

18. Graphs showing water levels for multiple-well monitoring site STK-6 (002N006E29H001M, -29H002M, and -29H003M), Eastern San Joaquin Groundwater Subbasin, California, individual wells, and with depth

19. Photograph of data collection and transmission platform located at multiple-well monitoring site 002N006E11H004M, $-11 \mathrm{H} 005 \mathrm{M},-11 \mathrm{H} 006 \mathrm{M}$, and $-11 \mathrm{H} 007 \mathrm{M}$ (STK-2), near Morada Lane, Stockton, California, March 26, 2007

20. Map showing locations of study area and well sampling sites for depth-dependent water chemistry coupled with pumped and unpumped fluid-velocity logs, Eastern San Joaquin Groundwater Subbasin, California

21. Photograph of electromagnetic flowmeter logging, City of Stockton well 001N007E31C001M (SSS-5), Stockton, California, March 20, 2008

22. Diagrams of resistivity log, well-bore flow log, well construction, and selected depth-dependent water-quality data from well 001N007E08H002M, Eastern San Joaquin Groundwater Subbasin, California, Febuary 24, 2005

23. Diagrams of resistivity log, well-bore flow log, well construction, and selected depth-dependent water-quality data from well 001N007E20N001M, Eastern San Joaquin Groundwater Subbasin, California, August 2, 2004

24. Diagrams of resistivity log, well-bore flow log, well construction, and selected depth-dependent water-quality data from well 001N007E28F001M, Eastern San Joaquin Groundwater Subbasin, California, July 19, 2005.

25. Diagrams of resistivity log, well-bore flow log, well construction, and selected depth-dependent water-quality data from well 001N007E31C001M, Eastern San Joaquin Ground-Water Subbasin, California, March 26, 2008

26. Diagrams of resistivity log, well-bore flow log, well construction, and selected depth-dependent water-quality data from well 002N006E010001M, Eastern San Joaquin Groundwater Subbasin, California, August 9, 2006

27. Diagrams of resistivity log, well-bore flow log, well construction, and selected depth-dependent water-quality data from well 002N006E040001M, Eastern San Joaquin Groundwater Subbasin, California, July 13-14, 2005

28. Diagrams of resistivity log, well-bore flow log, well construction, and selected depth-dependent water-quality data from well 002N006E05F001M, Eastern San Joaquin Groundwater Subbasin, California, August 3, 2004

29. Diagrams of resistivity log, well-bore flow log, well construction, and selected depth-dependent water-quality data from well 002N006E11H003M, Eastern San Joaquin Groundwater Subbasin, California, June 20, 2007

30. Diagrams of resistivity log, well-bore flow log, well construction, and selected depth-dependent water-quality data from well 002N006E12J001M, Eastern San Joaquin Groundwater Subbasin, California, August 8, 2006 


\section{Figures}

31. Diagrams of resistivity log, well-bore flow log, well construction, and selected depth-dependent water-quality data from well 002N006E24P004M, Eastern San Joaquin Groundwater Subbasin, California, August 5, 2004

32. Diagrams of resistivity log, well-bore flow log, well construction, and selected depth-dependent water-quality data from well 002N006E24P004M, Eastern San Joaquin Groundwater Subbasin, California, January 26-28, 2006

33. Diagrams of resistivity log, well-bore flow log, well construction, and selected depth-dependent water-quality data from well 002N006E27L001M, Eastern San Joaquin Groundwater Subbasin, California, February 16, 2005

34. Diagrams of gamma log, well construction, unpumped well-bore flow, fluid resistivity, fluid temperature, and lithology data from well 001N006E04P002M, Eastern San Joaquin Groundwater Subbasin, California, February 24, 2005

35. Diagrams of gamma log, well construction, unpumped well-bore flow, fluid resistivity, fluid temperature, and lithology data from well 001N006E012A001M, Eastern San Joaquin Groundwater Subbasin, California, February 23, 2005 66

36. Diagrams of gamma log, well construction, unpumped well-bore flow, fluid resistivity, fluid temperature, and lithology data from well 001N007E20N001M, Eastern San Joaquin Groundwater Subbasin, California, July 16, 2005.

37. Diagrams of gamma log, well construction, unpumped well-bore flow, fluid resistivity, fluid temperature, and lithology data from well 001N007E31C001M, Eastern San Joaquin Groundwater Subbasin, California, March 19, 2007 68

38. Diagrams of gamma log, well construction, unpumped well-bore flow, fluid resistivity, fluid temperature, and lithology data from well 002N006E010001M, Eastern San Joaquin Groundwater Subbasin, California, January 18, 2006 69

39. Diagrams of gamma log, well construction, unpumped well-bore flow, fluid resistivity, fluid temperature, and lithology data from well 002N006E040001M, Eastern San Joaquin Groundwater Subbasin, California, June 8, 2005

40. Diagrams of gamma log, well construction, unpumped well-bore flow, fluid resistivity, fluid temperature, and lithology data from well 002N006E05F001M, Eastern San Joaquin Groundwater Subbasin, California, February 17, 2005 .....

41. Diagrams of gamma log, well construction, unpumped well-bore flow, fluid resistivity, fluid temperature, and lithology data from well 002N006E11H003M, Eastern San Joaquin Groundwater Subbasin, California, March 27, 2007.

42. Diagrams of gamma log, well construction, unpumped well-bore flow, fluid resistivity, fluid temperature, and lithology data from well 002N006E12J001M, Eastern San Joaquin Groundwater Subbasin, California, May 25, 2006

43. Diagrams of gamma log, well construction, unpumped well-bore flow, fluid resistivity, fluid temperature, and lithology data from well 002N006E24P004M, Eastern San Joaquin Groundwater Subbasin, California, February 15, 2005

44. Diagrams of gamma log, well construction, unpumped well-bore flow, fluid resistivity, fluid temperature, and lithology data from well 003N006E10A001M, Eastern San Joaquin Groundwater Subbasin, California, February 25, 2005

45. Diagrams of gamma log, well construction, fluid resistivity, and fluid-temperature data, and flow data collected by use of three methods, from well 001N007E31C001M, Eastern San Joaquin Groundwater Subbasin, California 


\section{Figures}

46. Photograph of water-quality sampling using a Keck 2-inch diameter sample pump at multiple-well monitoring site 002N006E20E001M, -20E002M, and -20E003M (Swenson Park), Swenson Park, Stockton, California, April 27, 2004 ... 79

47. Photograph of water-quality sampling using a Grundfos 2-inch diameter sample pump at Sperry Road multiple-well monitoring site 001N006E36C003M and -36C004M, near Sperry Road, Stockton, California, April 29, 2004.

48. Map showing location of the study area and public-supply and private well sampling sites, Eastern San Joaquin Groundwater Subbasin, California

49. Photograph of depth-dependent sampling, City of Stockton well 001N007E31C001M (SSS-5), Stockton, California, March 26, 2008

50. Photograph of hose-reel with small diameter sample pump used for depth-dependent water-quality sampling, March 26, 2008

\section{Tables}

1. Multiple-well monitoring sites, Eastern San Joaquin Groundwater Subbasin, California

2. Lithologic log for multiple-well monitoring site STK-4 (wells 001N006E04J003M, -04J004M, and -04J005M) near Stockton, Eastern San Joaquin Groundwater Subbasin, California, September 2005

3. Lithologic log for multiple-well monitoring site STK-1 (wells 002N005E01A002M, $-01 \mathrm{~A} 003 \mathrm{M},-01 \mathrm{~A} 004 \mathrm{M},-01 \mathrm{~A} 005 \mathrm{M}$, and -01A006M) near Stockton, Eastern San Joaquin Groundwater Subbasin, California, April-May 2005

4. Lithologic log for multiple-well monitoring site STK-5 (wells 002N006E08N001M, -08N002M, and -08N003M) near Stockton, Eastern San Joaquin Groundwater Subbasin, California, May 2006

5. Lithologic log for multiple-well monitoring site STK-2 (wells 200N006E11H004M, -11 H005M, -11H006M, and -11H007M) near Stockton, Eastern San Joaquin Groundwater Subbasin, California, May 2005

6. Lithologic log for unsaturated-zone monitoring site STK-3 (002N006E11H008M) near Stockton, Eastern San Joaquin Groundwater Subbasin, California, September 2005

7. Lithologic log for multiple-well monitoring site STK-6 (wells 002006E29H001M, -29H002M, and -29H003M) near Stockton, Eastern San Joaquin Groundwater Subbasin, California, May 2006

8. Transducer recording dates for multiple-well monitoring sites, Eastern San Joaquin Groundwater Subbasin, California

9. Well-construction data and dates of electromagnetic induction logging for selected multiple-well sites, Stockton, California 


\section{Tables}

10. Analytical methods and reporting limits for water samples submitted to the U.S. Geological Survey National Water Quality Laboratory, Denver, Colorado...

11. Nutrient data for water from selected multiple-well monitoring sites, Eastern San Joaquin Groundwater Subbasin, California, 2004-7

12. Field measurements and water-quality data for water from selected multiple-well monitoring sites, Eastern San Joaquin Groundwater Subbasin, California, 2004-7

13. Isotopic data for water from selected multiple-well monitoring sites, Eastern San Joaquin Groundwater Subbasin, California, 2004-7

14. Nutrient data for water from selected wells, Eastern San Joaquin Groundwater Subbasin, California, 2003-7

15. Field measurements and water-quality data for water from selected wells, Eastern San Joaquin Groundwater Subbasin, California, 2003-7 101

16. Isotopic data for water from selected wells, Eastern San Joaquin Groundwater Subbasin, California, 2003-7

17. Sampling-well sites, Eastern San Joaquin Groundwater Subbasin, California ...... 120

18. Nutrient data for water from selected depth-dependent wells, Eastern San Joaquin Groundwater Subbasin, California, 2004-8

19. Field measurements and water-quality for water from selected depth-dependent wells, Eastern San Joaquin Groundwater Subbasin, California, 2004-8

20. Isotopic data for water from selected depth-dependent wells, Eastern San Joaquin Groundwater Subbasin, California, 2004-8

21. Identification numbers and screen depths for depth-dependent wells, Eastern San Joaquin Groundwater Subbasin, California

22. Selected dissolved ions and isotopes in pore water extracted by pressure from core material from selected multiple-well monitoring sites, Eastern San Joaquin Groundwater Subbasin, California....

23. Selected trace-element composition of acid extracts of pore water from core material and cuttings from selected multiple-well monitoring sites, Eastern San Joaquin Groundwater Subbasin, California 


\section{Conversion Factors}

Inch/Pound to SI

\begin{tabular}{lcl}
\hline \multicolumn{1}{c}{ Multiply } & By & \multicolumn{1}{c}{ To obtain } \\
\hline inch (in.) & Length & \\
foot (ft) & 2.54 & centimeter $(\mathrm{cm})$ \\
mile (mi) & 0.3048 & meter $(\mathrm{m})$ \\
& 1.609 & kilometer $(\mathrm{km})$ \\
\hline square mile $\left(\mathrm{mi}^{2}\right)$ & Area & \\
square mile $\left(\mathrm{mi}^{2}\right)$ & 259.0 & hectare $(\mathrm{ha})$ \\
& 2.590 & square kilometer $\left(\mathrm{km}^{2}\right)$ \\
\hline gallon (gal) & Volume & \\
acre-foot (acre-ft) & 3.785 & liter $(\mathrm{L})$ \\
acre-foot (acre-ft) & 1,233 & cubic meter $\left(\mathrm{m}^{3}\right)$ \\
& 0.001233 & cubic hectometer $\left(\mathrm{hm}^{3}\right)$ \\
acre-foot per year (acre-ft/yr) & Flow rate & \\
acre-foot per year (acre-ft/yr) & 1,233 & cubic meter per year $\left(\mathrm{m}^{3} / \mathrm{yr}\right)$ \\
foot per minute (ft/min) & 0.001233 & cubic hectometer per year $(\mathrm{hm} 3 / \mathrm{yr})$ \\
\hline
\end{tabular}

SI to Inch/Pound

\begin{tabular}{lcl}
\hline \multicolumn{1}{c}{ Multiply } & By & To obtain \\
\hline & Length & \\
\hline centimeter (cm) & 0.3937 & inch (in.) \\
millimeter (mm) & 0.03937 & inch (in.) \\
\hline & Volume & \\
\hline liter (L) & 0.2642 & gallon (gal) \\
liter (L) & 61.02 & cubic inch (in $\left.{ }^{3}\right)$ \\
\hline & Mass & \\
\hline gram (g) & 0.03527 & ounce, avoirdupois (oz) \\
\hline
\end{tabular}

Temperature in degrees Celsius $\left({ }^{\circ} \mathrm{C}\right)$ may be converted to degrees Fahrenheit $\left({ }^{\circ} \mathrm{F}\right)$ as follows:

$$
{ }^{\circ} \mathrm{F}=\left(1.8 \times{ }^{\circ} \mathrm{C}\right)+32
$$

Vertical coordinate information is referenced to the North American Vertical Datum of 1988 (NAVD 88).

Altitude, as used in this report, refers to distance above or below the vertical datum.

Specific conductance is given in microsiemens per centimeter at 25 degrees Celsius $(\mu \mathrm{S} / \mathrm{cm}$ at $\left.25^{\circ} \mathrm{C}\right)$.

Concentrations of chemical constituents in water are given either in milligrams per liter (mg/L) or micrograms per liter $(\mu \mathrm{g} / \mathrm{L})$. Radioactivity in water is given in picocuries per liter $(\mathrm{pCi} / \mathrm{L})$. 


\section{Abbreviations and Acronyms}

Abbreviations and Acronyms

$\begin{array}{ll}\text { ADAPS } & \text { Automated Data Processing System } \\ \text { DWR } & \text { California Department of Water Resources } \\ \text { EM } & \text { electromagnetic } \\ \text { GAMA } & \text { Groundwater Ambient Monitoring and Assessment } \\ \text { GOES } & \text { Geostationary Operational Environmental Satellite } \\ \text { HDP } & \text { heat dissipation probes } \\ \text { LYS } & \text { lysimeters } \\ \text { NESJGBA } & \text { Northeastern San Joaquin Ground Water Banking Authority } \\ \text { NWIS } & \text { National Water Information System } \\ \text { NWISWeb } & \text { National Water Information System Web page } \\ \text { ODEX } & \text { Overburden Drilling and Exploration } \\ \text { PES } & \text { polyethersulfone } \\ \text { PVC } & \text { polyvinyl chloride } \\ \text { SMCL } & \text { Secondary Maximum Contaminant Level } \\ \text { SP } & \text { spontaneous potential } \\ \text { USGS } & \text { U.S. Geological Survey }\end{array}$




\title{
Groundwater Data for Selected Wells within the Eastern San Joaquin Groundwater Subbasin, California, 2003-8
}

\author{
By Dennis A. Clark, John A. Izbicki, Loren F. Metzger, Rhett R. Everett, Gregory A. Smith, David O'Leary, \\ Nicholas F. Teague, and Matthew K. Burgess
}

\section{Abstract}

Data were collected by the U.S. Geological Survey from 2003 through 2008 in the Eastern San Joaquin Groundwater Subbasin, 80 miles east of San Francisco, California, as part of a study of the increasing chloride concentrations in groundwater processes. Data collected include geologic, geophysical, chemical, and hydrologic data collected during and after the installation of five multiple-well monitoring sites, from three existing multiple-well sites, and from 79 selected public-supply, irrigation, and domestic wells. Each multiple-well monitoring site installed as part of this study contained three to five 2-inch diameter polyvinyl chloride (PVC)-cased wells ranging in depth from 68 to 880 feet below land surface. Continuous water-level data were collected from the 19 wells installed at these 5 sites and from 10 existing monitoring wells at 3 additional multiple-well sites in the study area. Thirty-one electromagnetic logs were collected seasonally from the deepest PVC-cased monitoring well at seven multiple-well sites. About 200 water samples were collected from 79 wells in the study area. Coupled well-bore flow data and depth-dependent water-quality data were collected from 12 production wells under pumped conditions, and well-bore flow data were collected from 10 additional wells under unpumped conditions.

\section{Introduction}

Coincident with groundwater pumping and subsequent declines in water levels, chloride concentrations have increased in water from wells in the Eastern San Joaquin Groundwater Subbasin (fig. 1), about 80 miles east of San Francisco, California (Montgomery Watson, Inc., 2000; CDM, Inc., 2001; Northeastern San Joaquin County Groundwater Banking Authority, 2004; Izbicki and others, 2006). Water samples from a number of public-supply, agricultural, and domestic wells in the western part of the subbasin adjacent to the San Joaquin Delta exceed the U.S. Environmental Protection Agency Secondary Maximum Contaminant Level (SMCL) for chloride of 250 milligrams per liter (mg/L) (U.S. Environmental Protection Agency, 2006). Some of these wells have been removed from service.

The areal extent of high-chloride water in the subbasin has been mapped in previous studies (Montgomery Watson, Inc., 2000; CDM, Inc., 2001; Izbicki and others, 2006). However, the vertical distribution of this high-chloride water and its movement through the freshwater aquifers to wells is not known. Potential sources of high-chloride water include surface water from the Sacramento-San Joaquin Delta, porewater within Delta sediments, water from saline aquifers that underlie freshwater aquifers, and irrigation return water. In addition to high-chloride concentrations, some wells in the study area yield water having arsenic (Izbicki, Stamos, and others, 2008) or nitrate concentrations that exceed the Maximum Contaminant Level for these constituents (Northeastern San Joaquin County Groundwater Banking Authority, 2004). Other regional water-quality issues include the presence of organic compounds contributed by anthropogenic sources (Bennett and others, 2006).

The Northeastern San Joaquin Ground Water Banking Authority (NESJGBA) and the California Department of Water Resources (DWR) undertook a study in cooperation with the U.S. Geological Survey (USGS) to better understand the areal and vertical distribution and source of high-chloride water to wells within the Eastern San Joaquin Groundwater Subbasin. Data collection for the study began in August 2003 and ended in September 2008. Data collection included test drilling and multiple-well monitoring site installation; water-level measurements; borehole geophysical data collection, including electromagnetic logging and coupled well-bore flow and depth-dependent sample collection; and water-quality sample collection and analysis. 


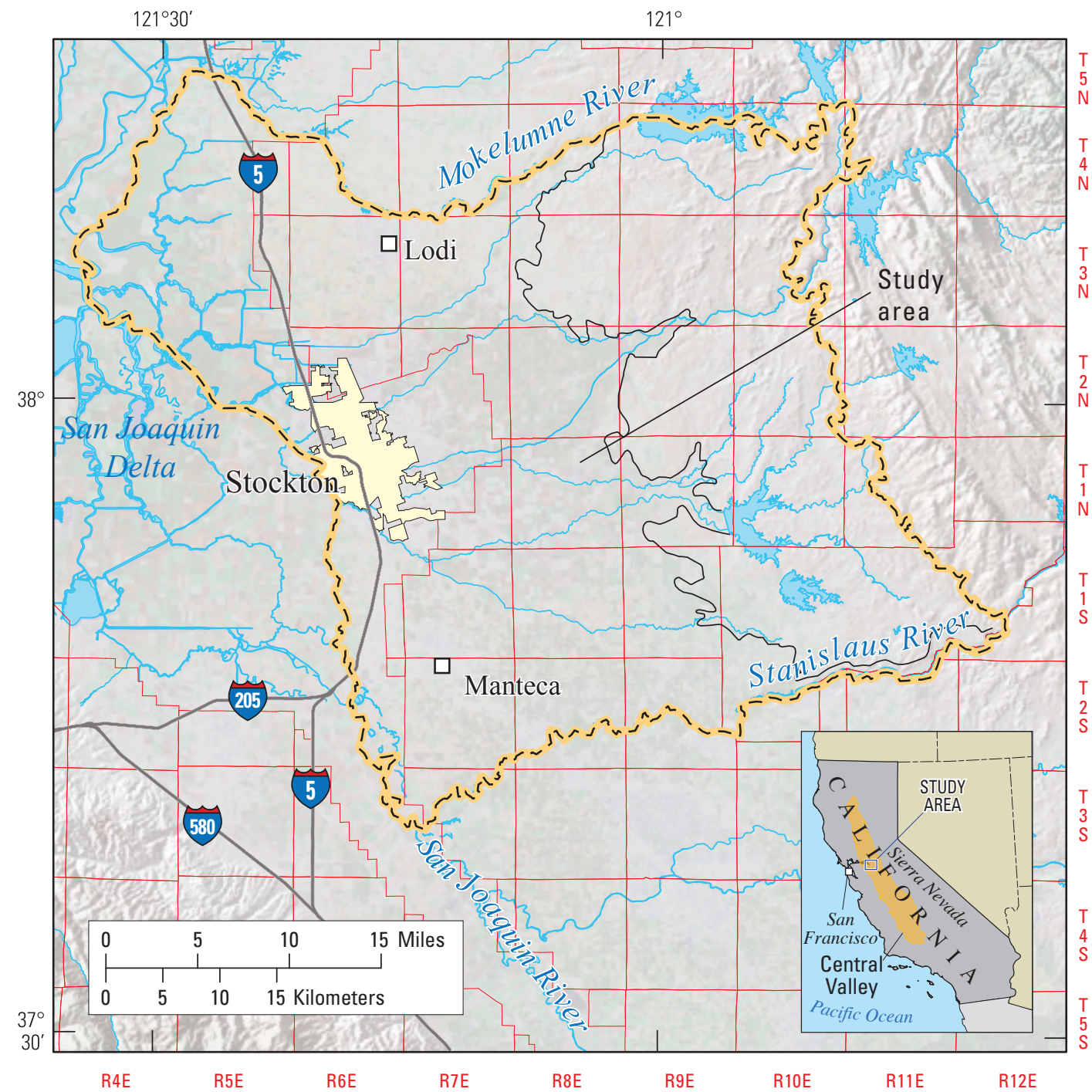

\section{EXPLANATION}

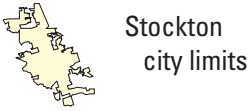

Eastern San Joaquin Groundwater Subbasin
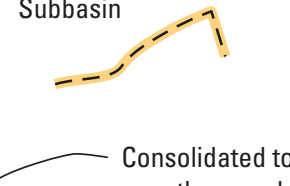
partly consolidated rock boundary

Figure 1. Location of study area, Eastern San Joaquin Groundwater Subbasin, California.

\section{Hydrogeologic Setting}

The study area is the Eastern San Joaquin Groundwater Subbasin near Stockton, Calif. (fig. 1), about 80 miles east of San Francisco. The groundwater subbasin is about 1,100 square miles (California Department of Water Resources, 2006) and is part of the larger San Joaquin Groundwater Basin that occupies the southern two-thirds of the Central Valley of California. The climate of the area is characterized by hot, dry summers and cool, moist winters. Average annual precipitation ranges from 10 to 18 inches (Soil Conservation Service, 1992). Precipitation is greater in the Sierra Nevada to the east of the study area. Runoff from the Sierra Nevada, primarily as snowmelt, helps sustain flow in rivers and streams that cross the study area. The largest of these, the Mokelumne and Stanislaus Rivers, bound the study area to the north and south, respectively. The San Joaquin River, which drains the San Joaquin Valley from the south, bounds the study area to the west, and the foothills of the Sierra Nevada form the eastern boundary (fig. 1). In 2000, the population within the study area was about 580,000 . The population is expected to increase to more than 1.2 million by 2040 (CDM, Inc., 2001). 
The study area is underlain by several thousand feet (ft) of consolidated, partly consolidated, and unconsolidated deposits (California Department of Water Resources, 1967). The deeper, more consolidated deposits are of marine origin. Water in these deposits is saline (Mendenhall, 1908) and is not extensively used for water supply. However, these deeper deposits have been explored for oil and gas and for the potential storage of waste. These deeper marine deposits are separated from the overlying alluvial-fan and delta deposits of the San Joaquin River and tributaries by volcanic deposits.

Volcanic sands within the Mehrten and Valley Springs Formations are the oldest fresh water-bearing deposits commonly pumped for water supply in the study area. These consolidated to partly consolidated sands crop out on the east side of the subbasin and are an important source of supply in that area (California Department of Water Resources, 1967). The Mehrten Formation also contains low-permeability pyroclastic deposits, lahars, and debris flows (Curtis, 1954). Alluvium eroded from the volcanic sands blankets these low-permeability volcanic deposits that form the effective base of freshwater in the study area, about 800 to $1,000 \mathrm{ft}$ below land surface near Stockton (California Department of Water Resources, 1967).

The overlying alluvial deposits are composed of varying amounts of sand, silt, clay, and gravel—eroded from crystalline rock in the Sierra Nevada. These deposits include recent alluvium along stream and river channels, the Victor Formation (California Department of Water resources, 1967) and Arroyo Seco Gravel of Pleistocene age, and older alluvial-fan deposits of the Modesto (California Department of Water resources, 1967), Riverbank, and Laguna Formations (California Department of Water Resources, 2003). The Modesto, Riverbank and Laguna Formations were largely eroded from the same source material, have similar lithology, and are almost indistinguishable on the basis of test drilling data (Piper and others, 1939), except where characteristic soil horizons have developed during long periods when deposition was not occurring (Burow and others, 1997; Jurgens and others, 2008). The contacts between the formations represent the surfaces of different alluvial fans established by uplift and changing climatic conditions in the Sierra Nevada. The surfaces of the fans have been dissected and backfilled by alluvial deposits from subsequent fan building. Buried stream-channel deposits produced in this manner often yield large quantities of water to wells (Burow and others, 1997). The degree of consolidation increases with age and depth of the deposits; their water-yielding properties generally decrease with increasing depth and consolidation (Piper and others, 1939).

Deposits underlying the present floodplain and Delta of the San Joaquin River are fine-grained and rich in organic material. These deposits interfinger with the alluvial deposits in the study area. Since Tertiary time, deposition in the Delta area has been controlled in part by uplift in the Sierra Nevada and Coastal Ranges and subsequent deepening of the California Trough along the axis of the Central Valley (Mendenhall, 1908; Piper and others, 1939). The fine-grained delta deposits yield only small amounts of water to wells, and in places water from wells is saline.

Under predevelopment conditions, groundwater movement in the alluvial deposits was from the base of the Sierra Nevada, northwest to the groundwater discharge area near the eastern edge of the Delta (Mendenhall, 1908). Groundwater that discharged to surface water, springs, and seeps in this area was fresh and low in dissolved minerals (Mendenhall, 1908). Surface water also infiltrated from the upper reaches of rivers and streams into underlying alluvial deposits and discharged along the lower reaches of these streams, sustaining baseflow during dry periods (Piper and others, 1939). Along the western margin of the study area, groundwater movement was from southeast to northwest along the axis of the San Joaquin Valley. This water also discharged to the Delta. (Mendenhall, 1908).

Groundwater in deep wells in the western part of the study area was artesian. Water from most deep artesian wells near Stockton was saline (Mendenhall, 1908); as a consequence, this water was not commonly used for agricultural or public supply. Saline water extracted during natural gas production from marine deposits in the Stockton area was discharged at land surface and "allowed to waste" (Mendenhall, 1908), or was used for recreational purposes because of its warm temperature.

The alluvial deposits currently are pumped extensively for water supply by using large capacity wells as deep as $780 \mathrm{ft}$, with an average depth of about $350 \mathrm{ft}$ (California Department of Water Resources, 2006). Groundwater pumping in excess of recharge caused water levels in the alluvial deposits east of the Delta to decline below sea level beginning in the late 1940s (California Department of Water Resources, 1967). The resulting cone of depression in the water table expanded and shifted eastward in recent years as pumping shifted eastward with population growth and with increasing chloride concentrations in the alluvial deposits near the Delta. With the exception of drought years in the late 1980s and early 1990 s, the minimum altitude of the pumping depression has increased in recent years as pumping for public supply has been distributed farther from the center of Stockton, and the size (volume) of the pumping depression expanded during this period. Groundwater recharge to the alluvial deposits within the study area is about 900,000 acre-feet per year (acre-ft/yr); in 2004, the total estimated overdraft was about 150,000 acre-feet. (CDM, Inc., 2001). 


\section{Purpose and Scope}

The purpose of this report is to present data collected from 2003 through 2008 in the Eastern San Joaquin Groundwater Subbasin as part of a study to better understand the increasing chloride concentrations and to estimate groundwater recharge in the area. Data in this report include geologic, geophysical, water chemistry, and hydrologic data collected at multiple-well monitoring sites installed as part of this study, geophysical data collected from existing wells in the study area, and water-chemistry data from pre-existing multiple-well monitoring sites and from public-supply, irrigation, and domestic wells sampled as part of this study.

\section{Drilling and Well Installation}

Five multiple-well monitoring sites, containing three to five 2-inch diameter polyvinyl chloride (PVC) monitoring wells in a single borehole, were installed as part of this study (table 1, fig. 2). These multiple-well sites included 001N006E04J003M-04J005M (1N/6E-4J3-5, Victory Park, STK-4), 002N005E01A002M-01A006M (2N/5E-1A2-6, Oak Grove Park, STK-1), 002N006E08N001M08N003M (2N/6E-8N1-3, Sandman Park, STK-5), 002N006E29H001M-29H003M (2N/6E-29H1-3, Atherton Park, STK-6), and 002N006E11H004M-11H007M (2N/6E-11H4-7, Morada Lane, STK-2). The five sites were drilled by the USGS Western Research Drilling Operation team to depths ranging from about 600 to $966 \mathrm{ft}$ by using the hydraulic mud-rotary method (fig. 3 ). The diameter of the boreholes ranged from 12.25 inches in the upper part of some boreholes to 5.25 inches in the lower part of some boreholes. Drill cuttings were collected at 20-ft intervals from the mud discharge at land surface using a \#120 sieve and from the screen on the shaker tank during drilling. Additional cuttings were collected where lithologic changes were observed during drilling. Drill cores also were collected from selected depths in selected boreholes. Geophysical logs were collected in open boreholes after drilling was completed and before wells were installed. Field descriptions of drill cuttings and geophysical logs were used to guide well design and installation.

An additional borehole 002N006E11H008M (STK-3) containing one 2-inch diameter PVC monitoring well, three lysimeters (LYS), and three heat dissipation probes (HDPs) was drilled adjacent to the 11H4-7 multiple-well site to provide data near the water table (fig. 2). HDP data are not presented in this report; however, the data are stored in San Diego USGS California Water Science Center. The borehole was drilled by a USGS drill rig and crew using the ODEX (Overburden Drilling and Exploration) air-hammer method, also known as the under-reamer method (Driscoll, 1986; Hammermeister and others, 1986). When this technique is used, mud is not used as a drilling fluid and disturbance to the aquifer material near the borehole is minimized. During drilling, the borehole is stabilized by the emplacement of steel casing in the hole as the drill bit advances into the ground. Drill depth was $120 \mathrm{ft}$ and the borehole diameter was 8.75 inches. Cuttings were collected at $1-\mathrm{ft}$ intervals from the cyclone discharge during drilling.

\section{Lithologic Data}

Cuttings collected during test drilling were initially described in the field during drilling, and more detailed descriptions were done in the office after drilling. The cuttings are archived at the USGS office in San Diego, Calif. Detailed lithologic logs were compiled from descriptions of drill cuttings, core material, and observations recorded during drilling in the field and in the office (tables 2-7). The textures of drill cuttings and core material were determined by using a method developed by Folk (1954; fig. 4), and the particle-size distributions were described by using the National Research Council (1947) classification. This approach allows general grain-size descriptions (such as sand) to be correlated to size limits in millimeters or inches. Color, determined on moist cuttings from the hydraulic rotary boreholes and on dry cuttings from the ODEX borehole, was described according to numerical designations in the Munsell Soil Color Chart (Munsell Color, 1975, 1994). 
Table 1. Multiple-well monitoring sites, Eastern San Joaquin Groundwater Subbasin, California.

[Site locations are shown in figure 2. Depths are below land surface. State well number, see well-numbering diagram in text. Well names beginning with STK were drilled by the U.S. Geological Survey. Abbreviations: ft, feet; HDP, heat-dissipation probe; LSD, land surface datum; LYS, suction-cup lysimeter; NAVD88, North American Vertical Datum of 1988; USGS ID, U.S. Geological Survey identification number: the unique number for each site in USGS National Water Information System (NWIS) database]

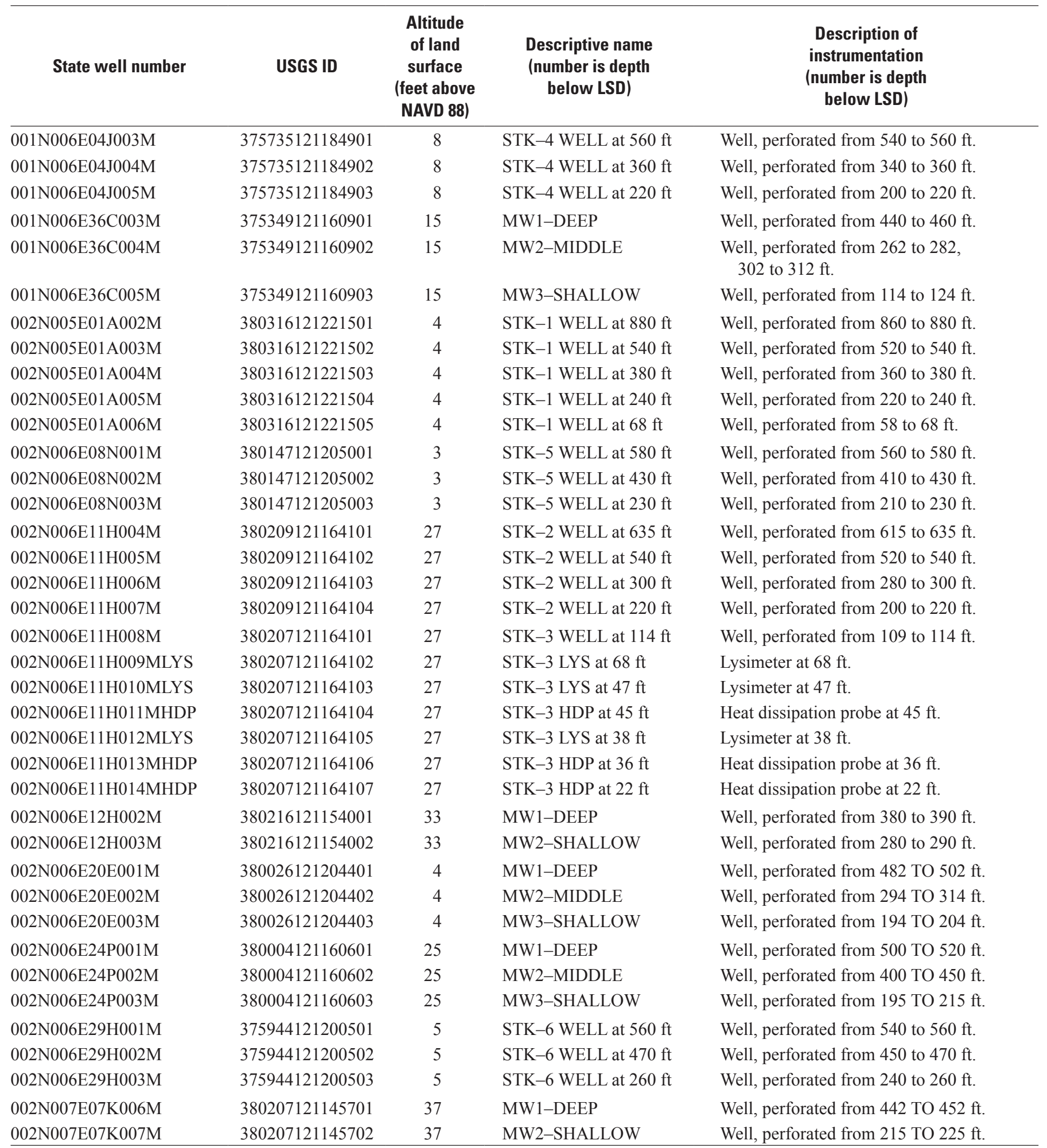




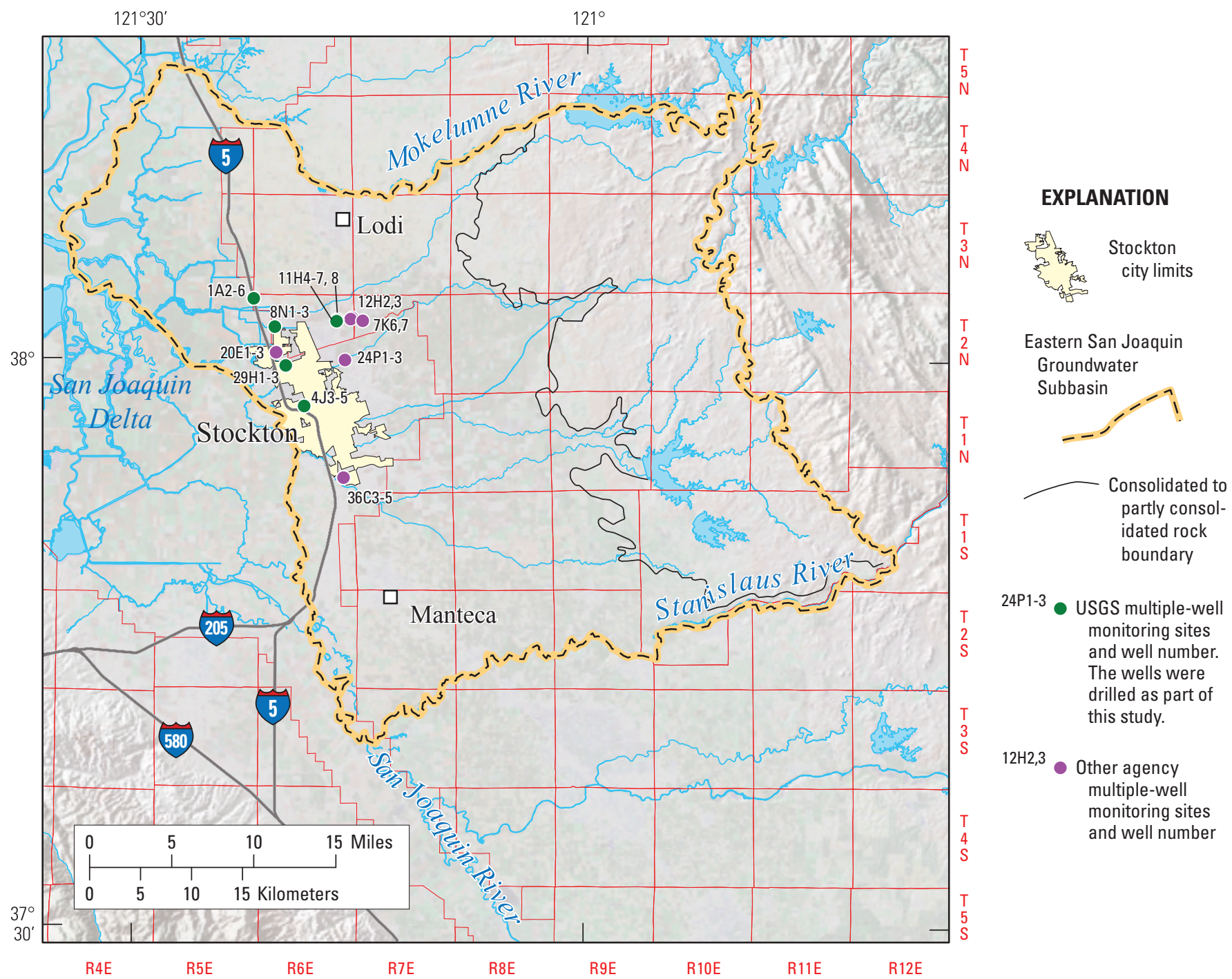

Figure 2. Location of the multiple-well monitoring sites, Eastern San Joaquin Groundwater Subbasin, California. 


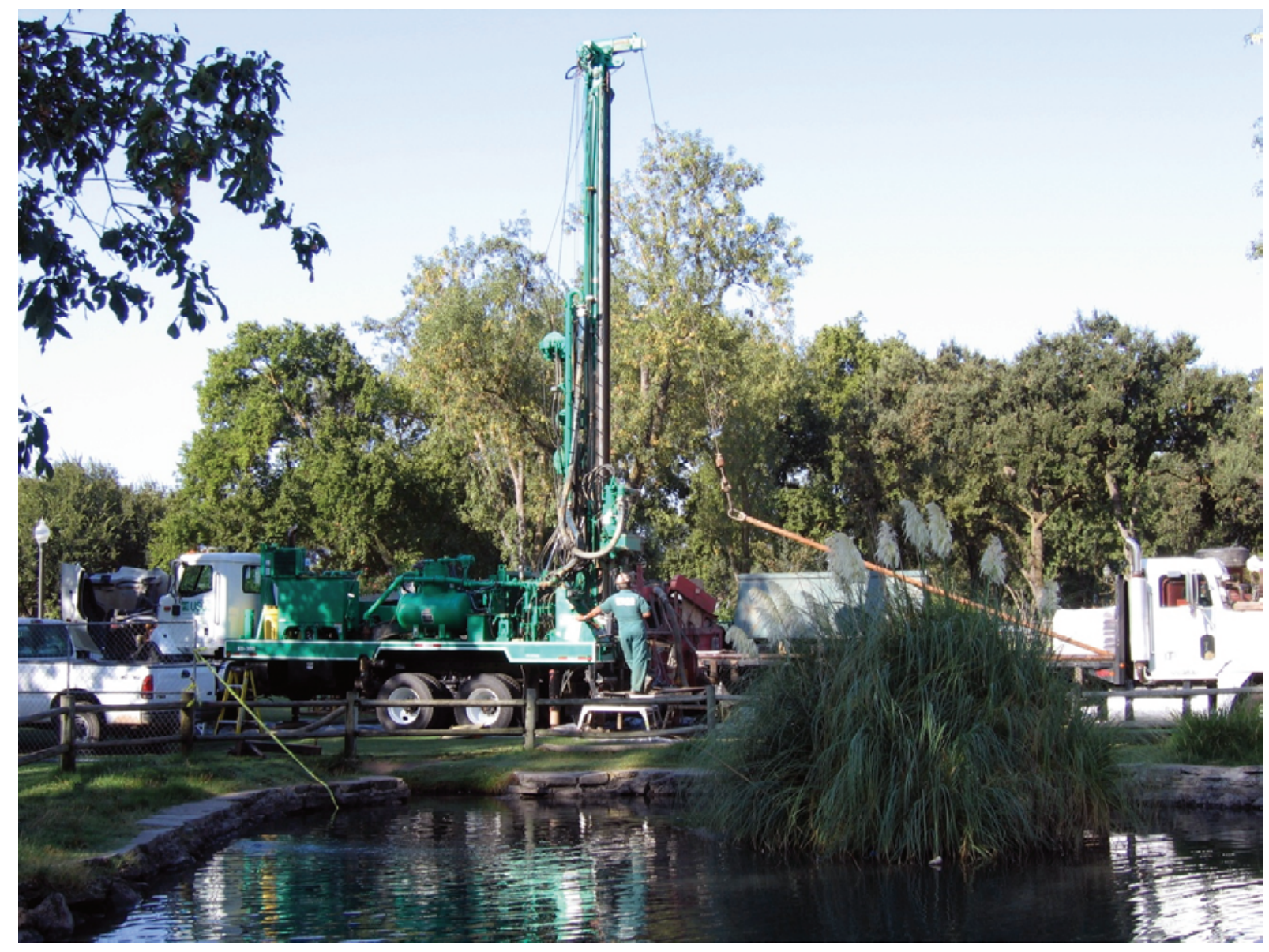

Photograph by Rhett Everett, U.S. Geological Survey, 2005

Figure 3. U.S. Geological Survey drill rig used to install wells 001N006E04J003M, and -04J004M at multiple-well monitoring site STK-4 in Victory Park, Stockton, California, September 12, 2005. 

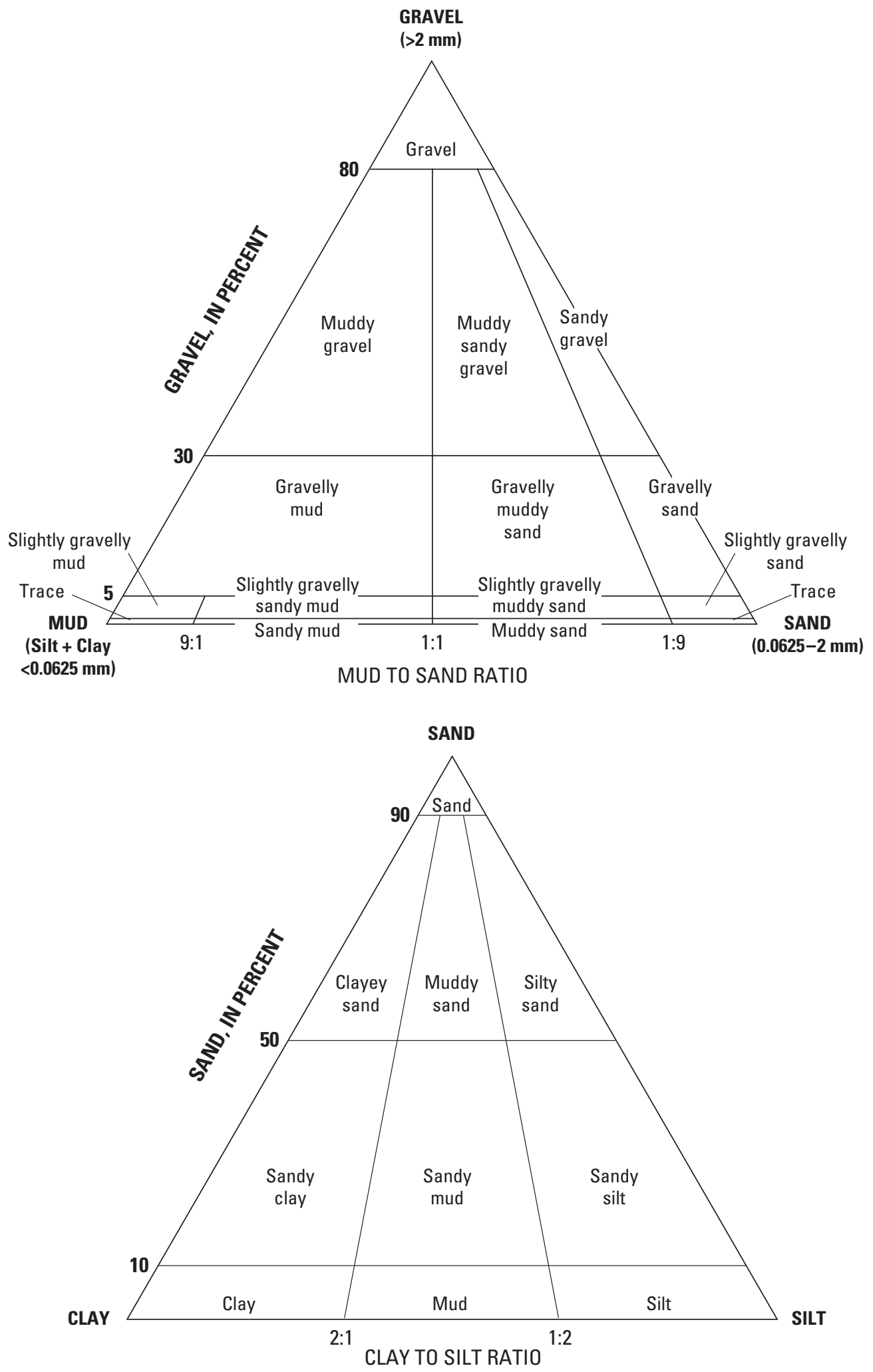

Figure 4. Piper diagrams of rock-type nomenclature used for description of texture in lithologic logs. Modified from Folk, 1954. 


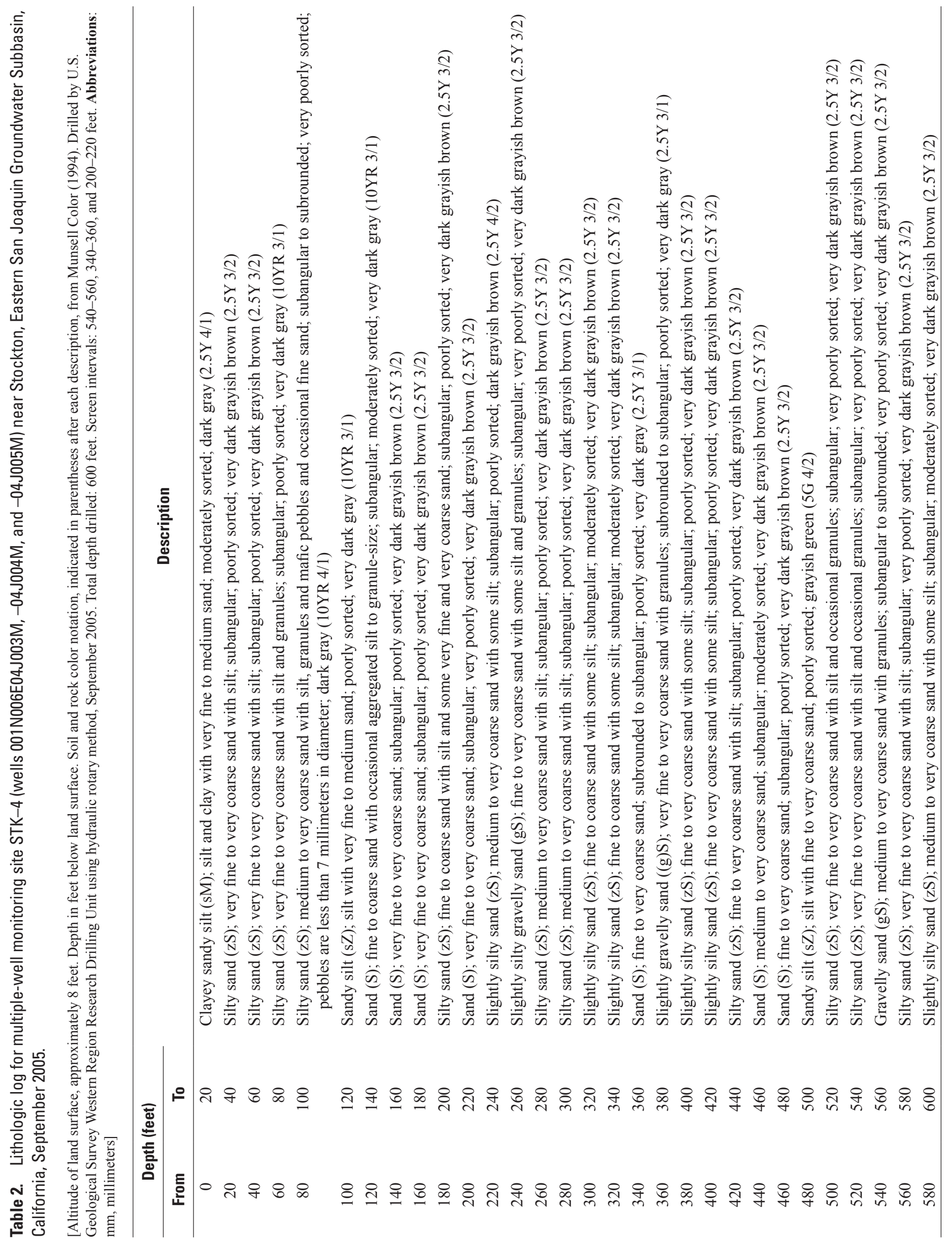




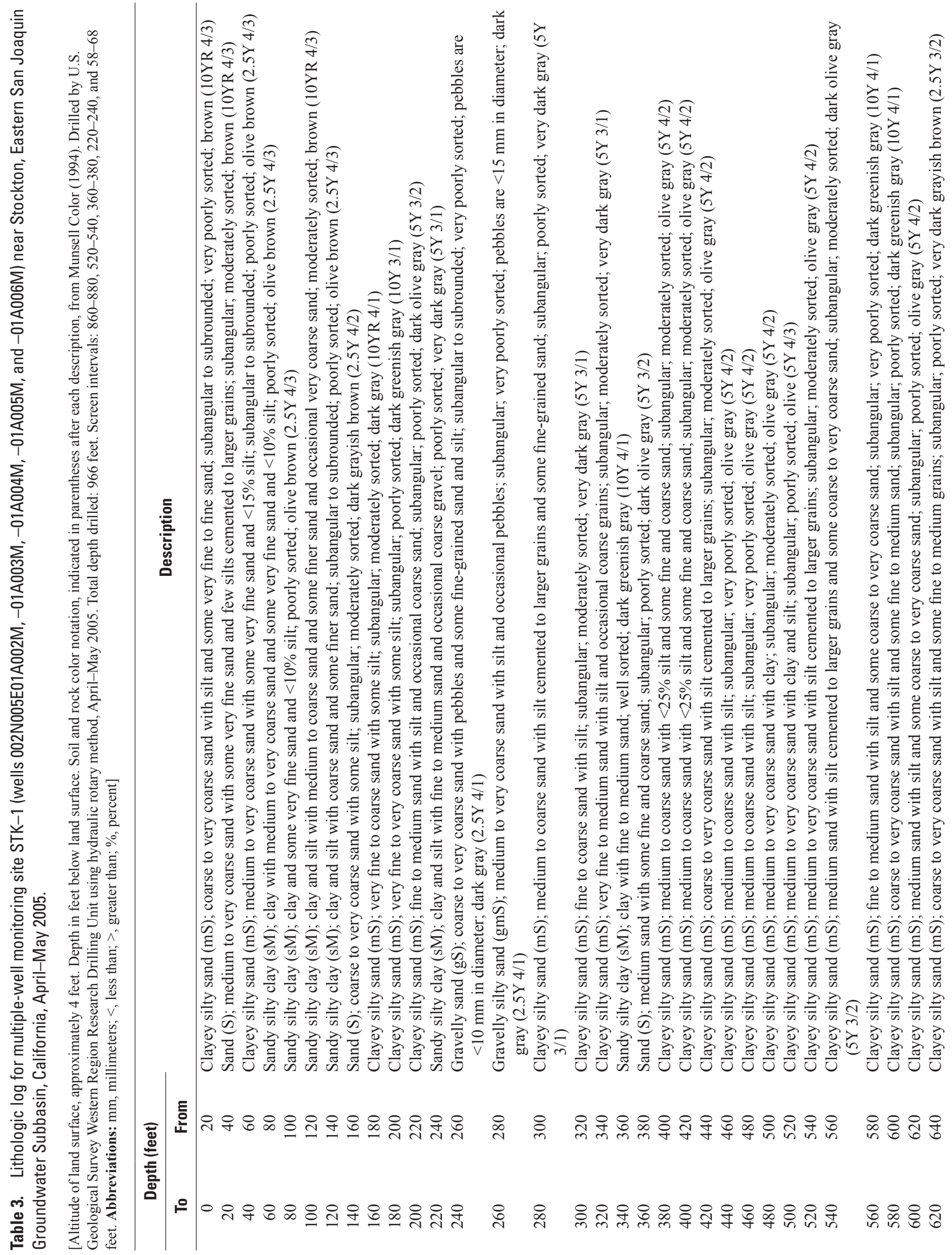




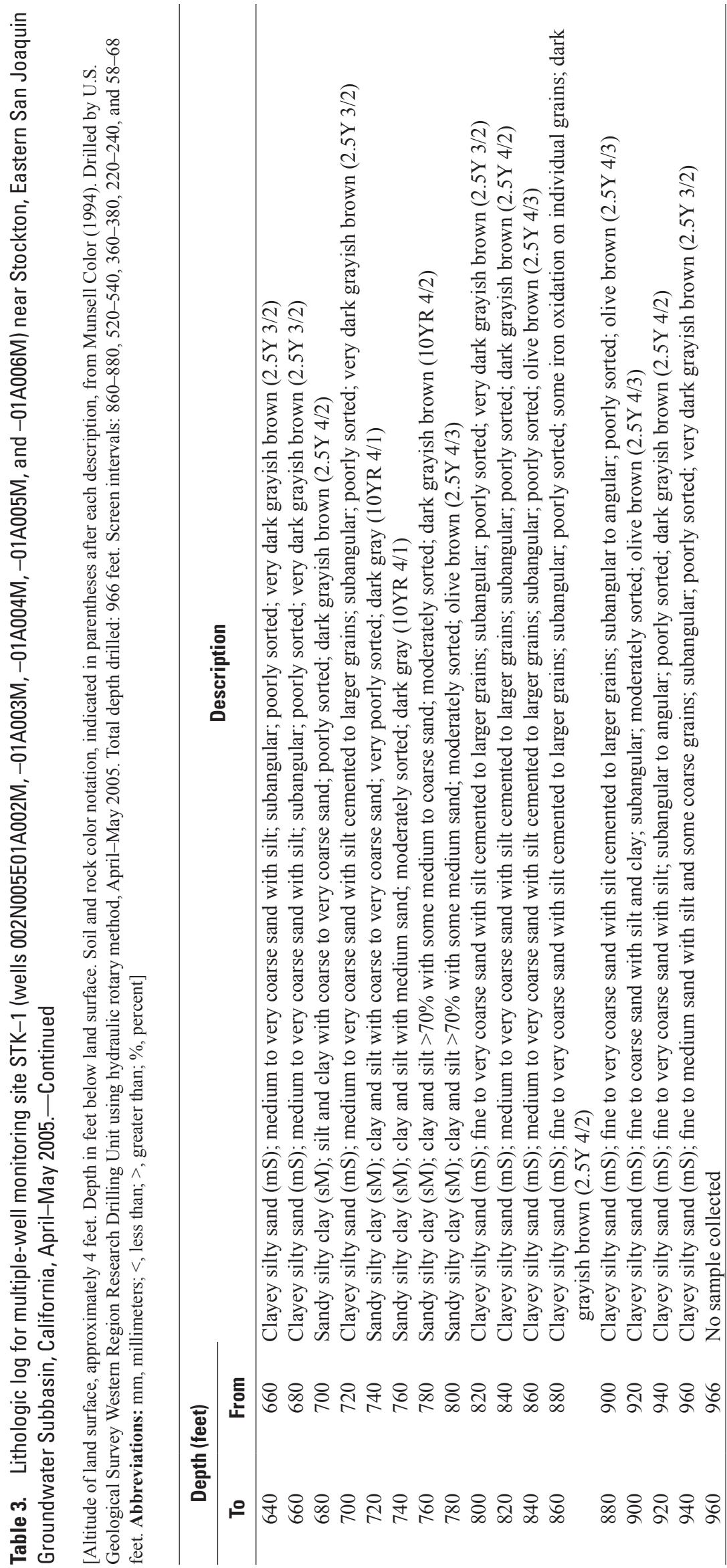




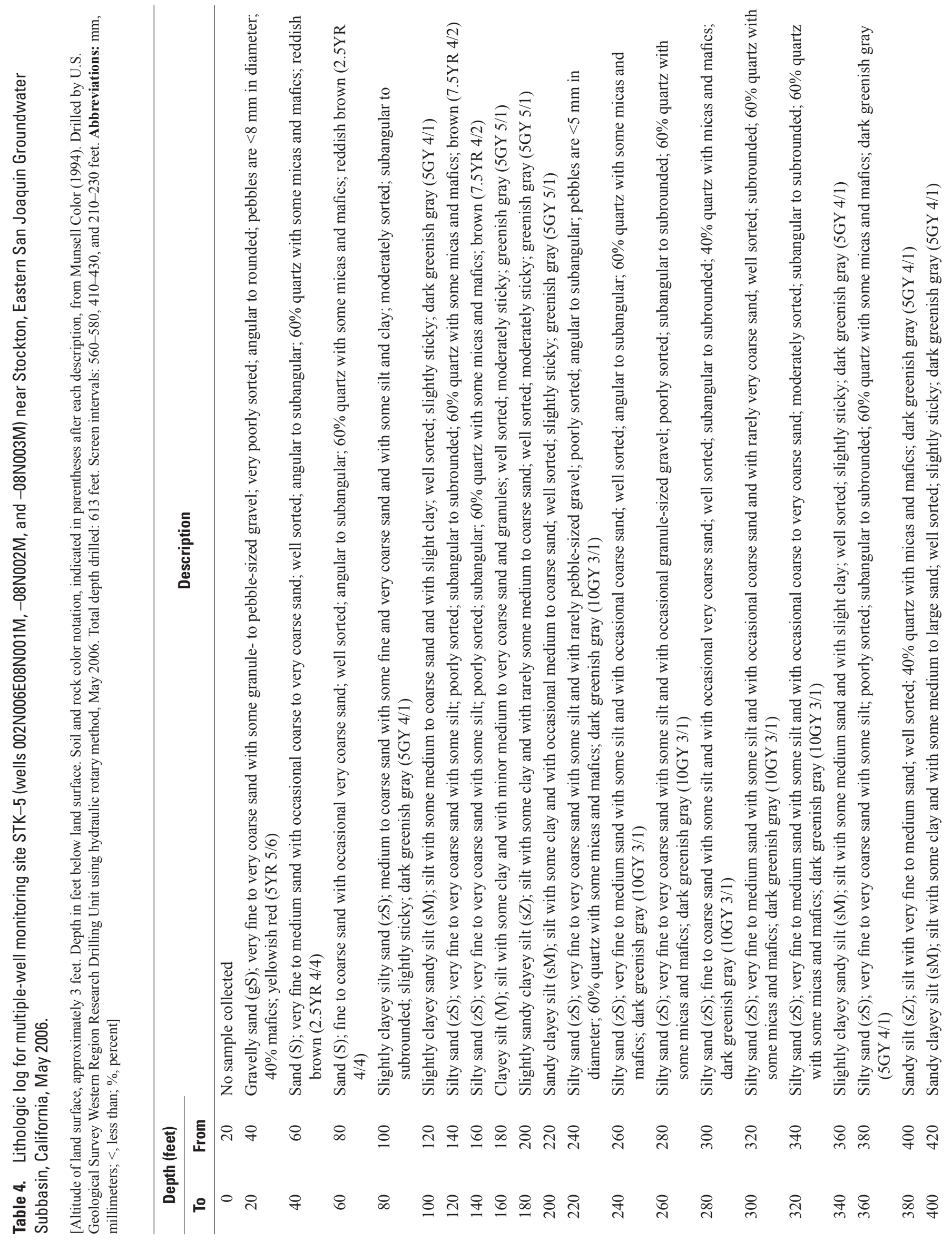




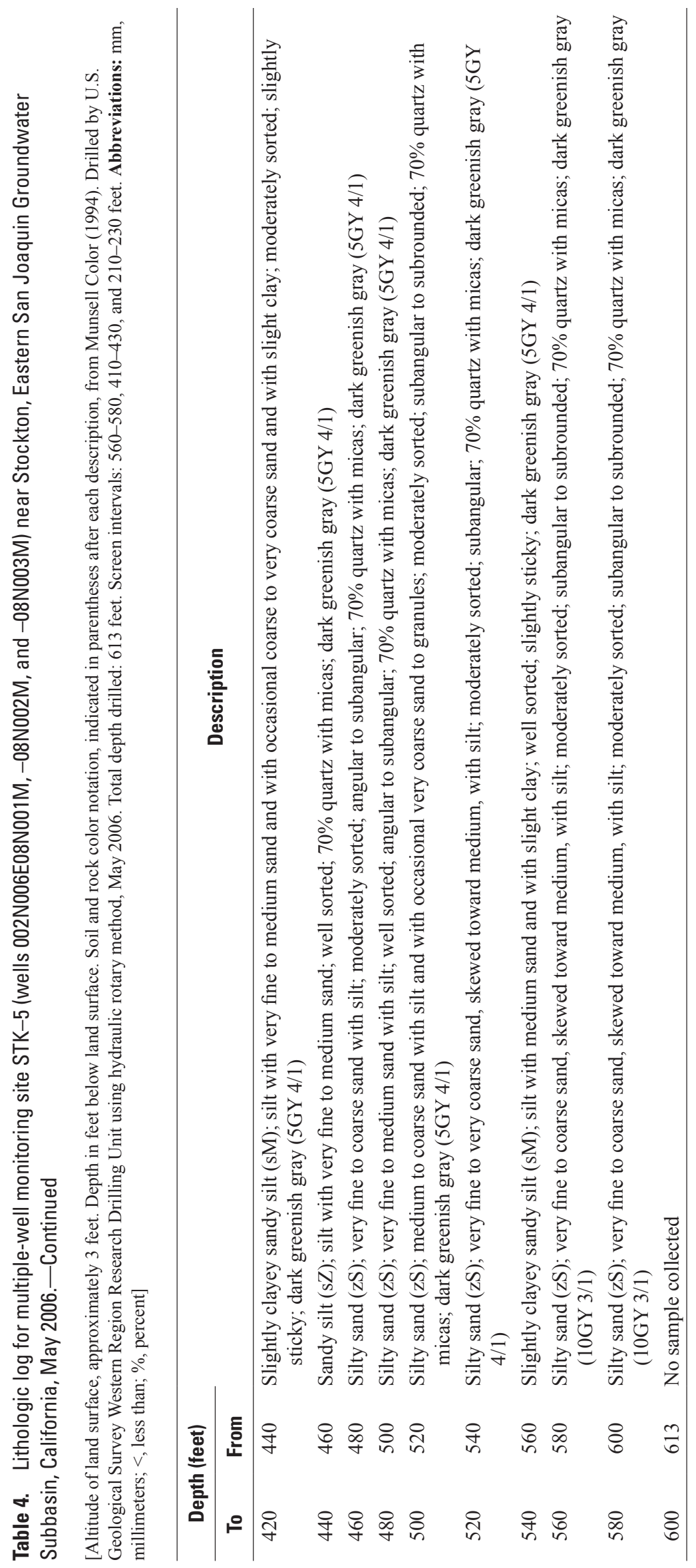




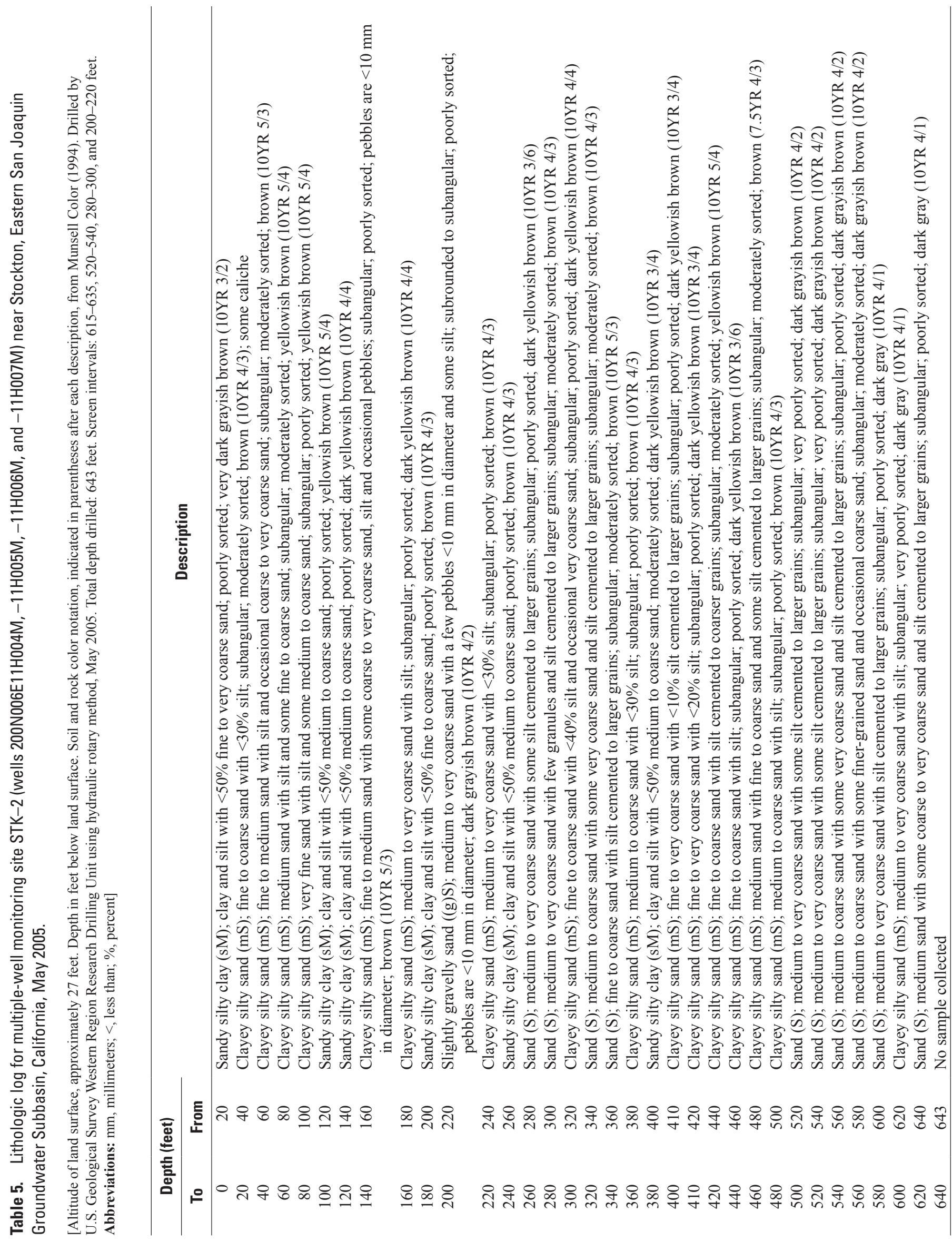




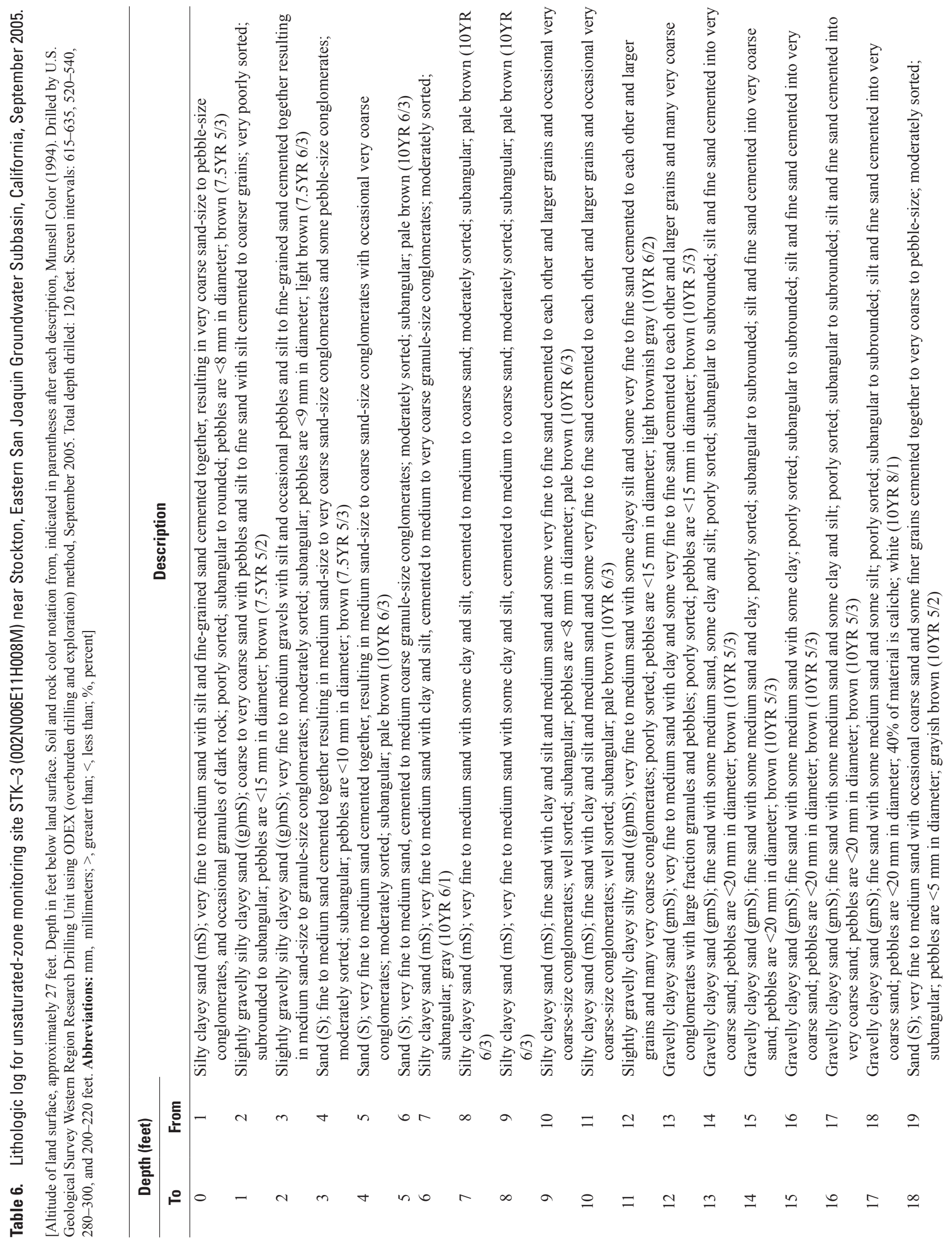




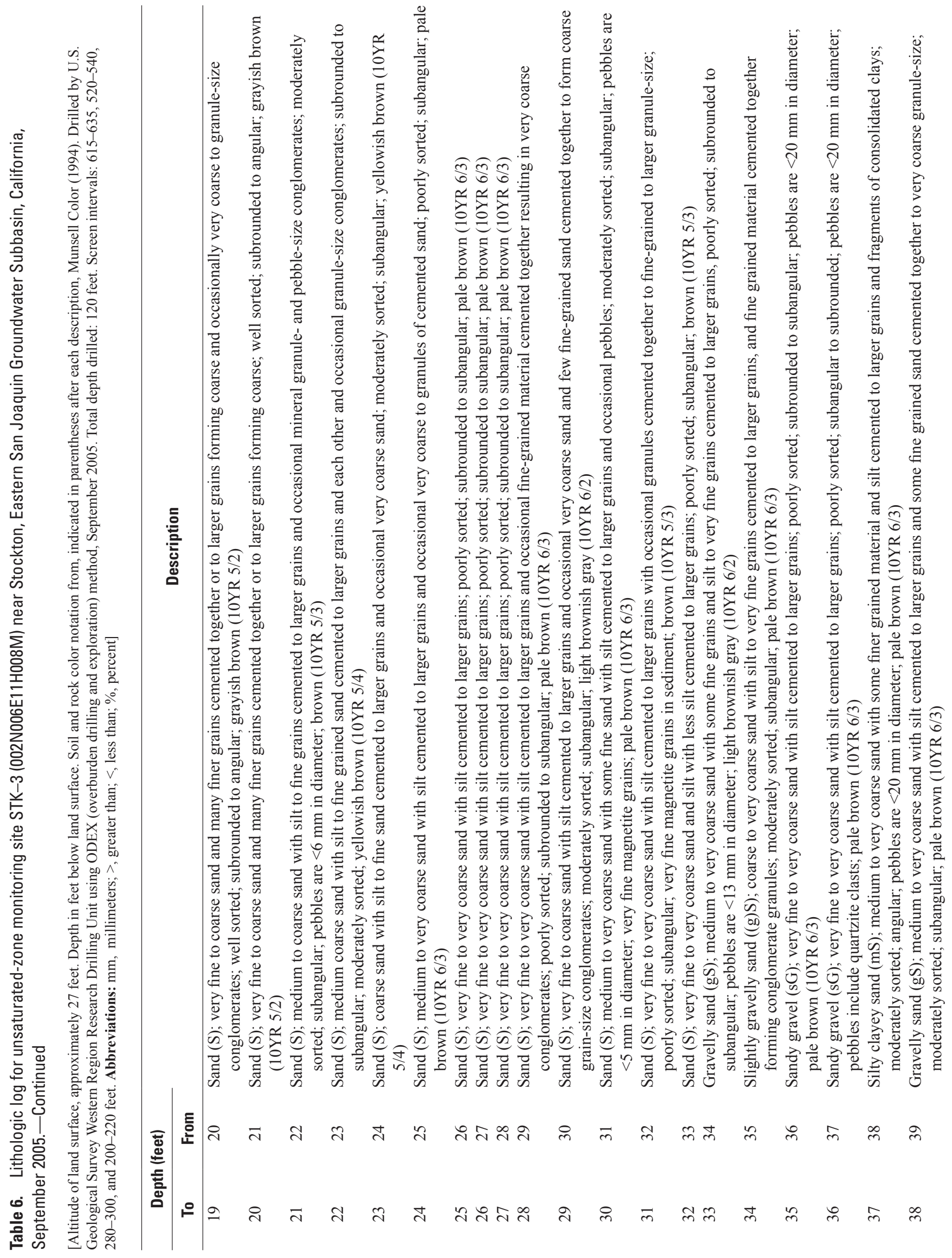




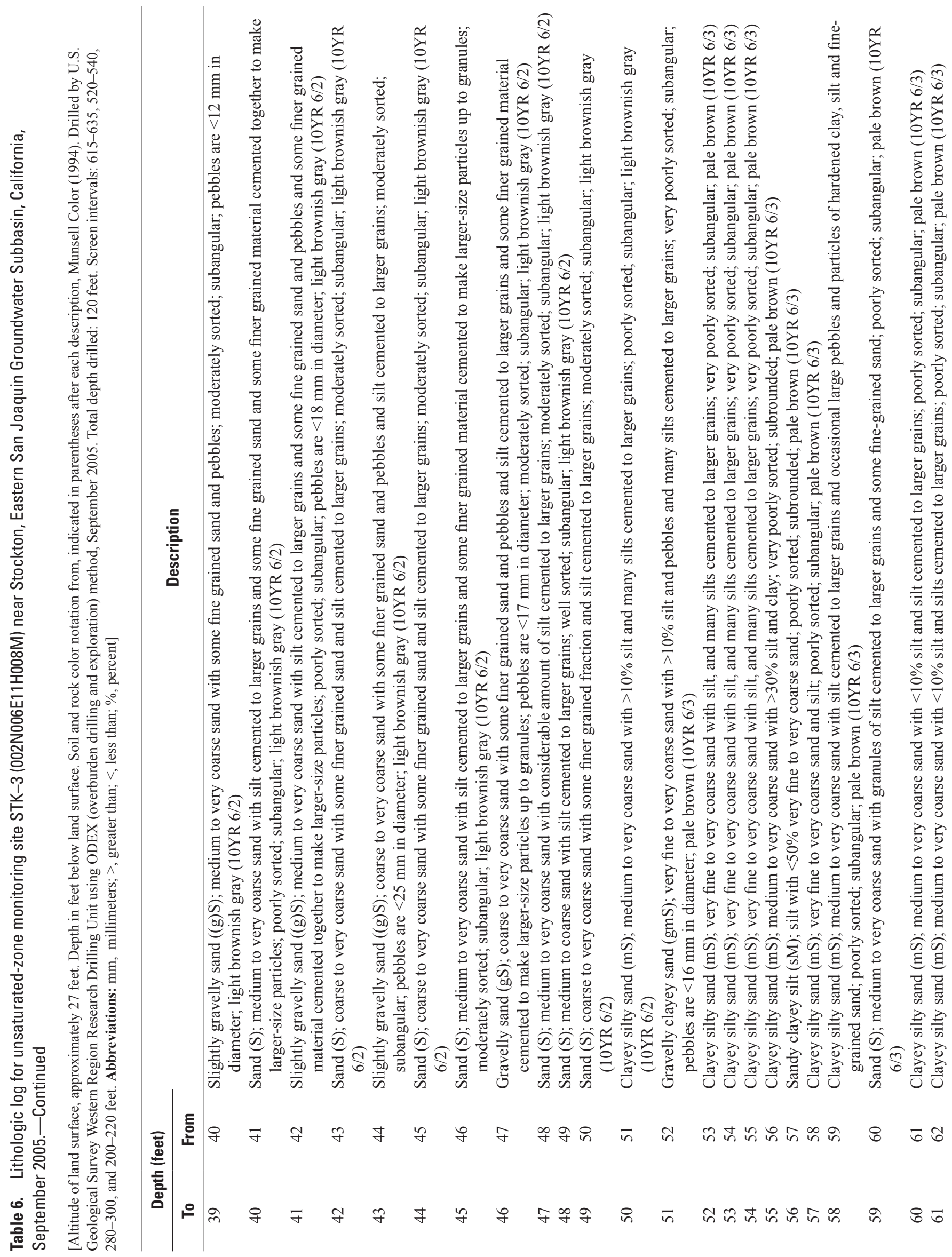




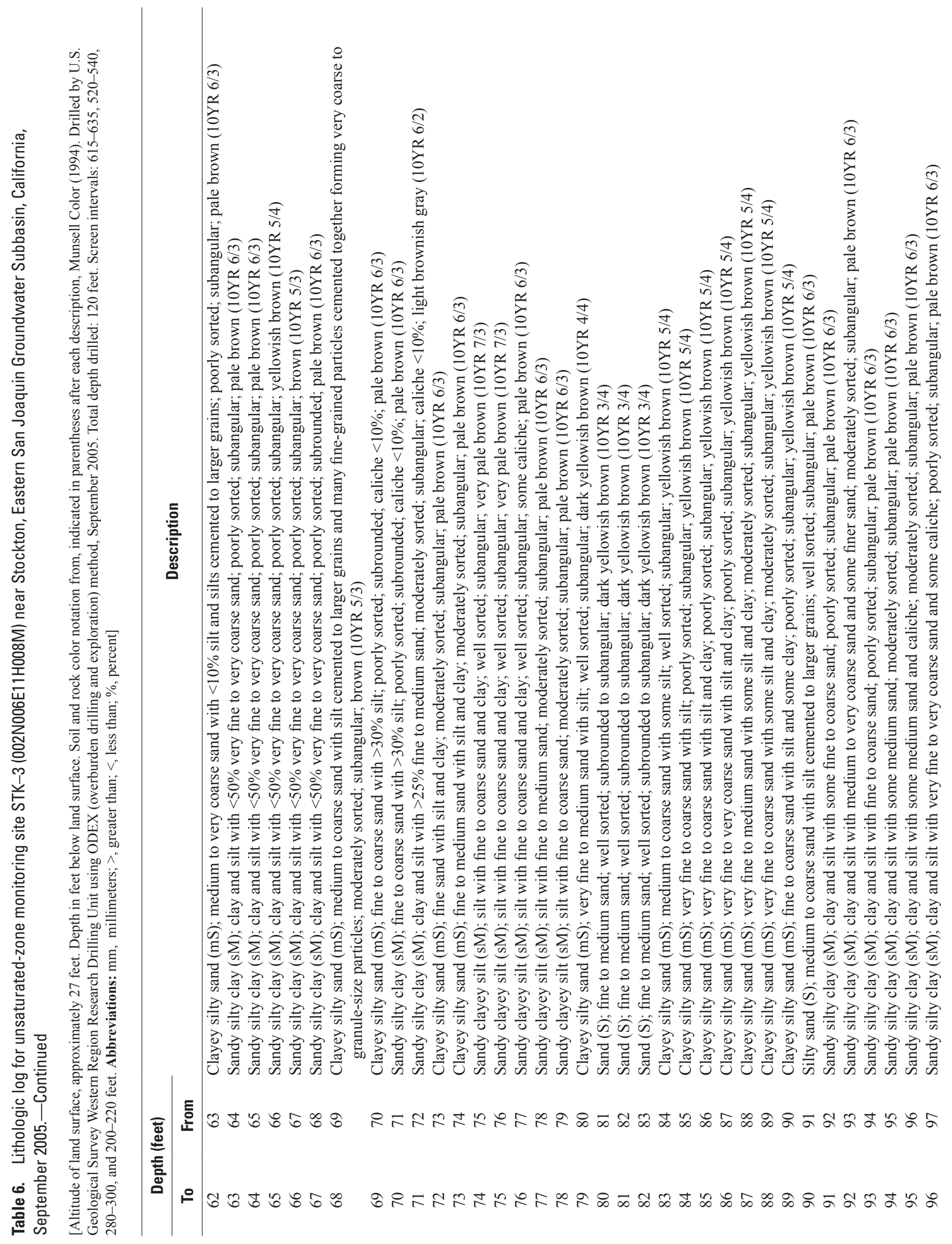




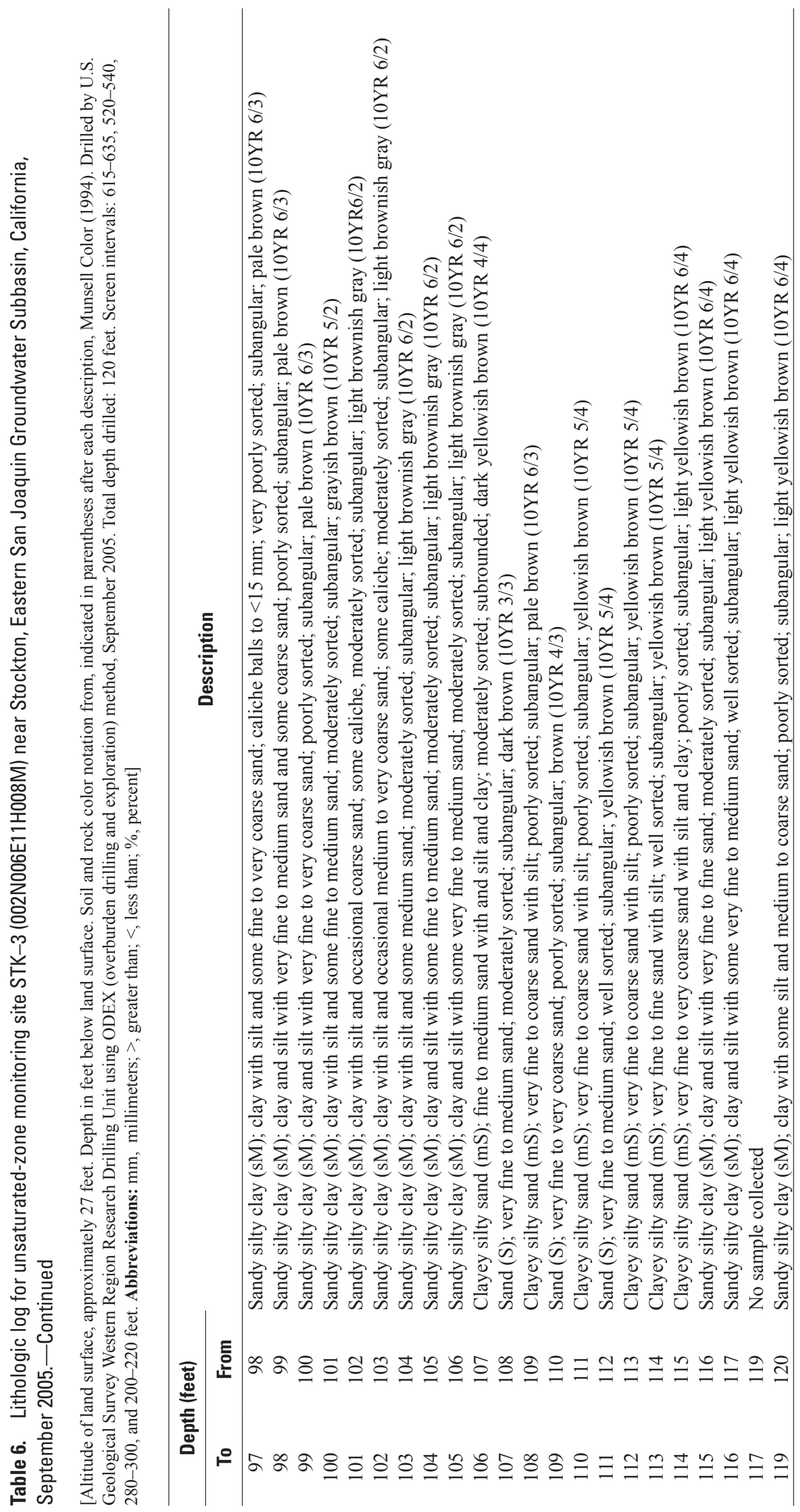




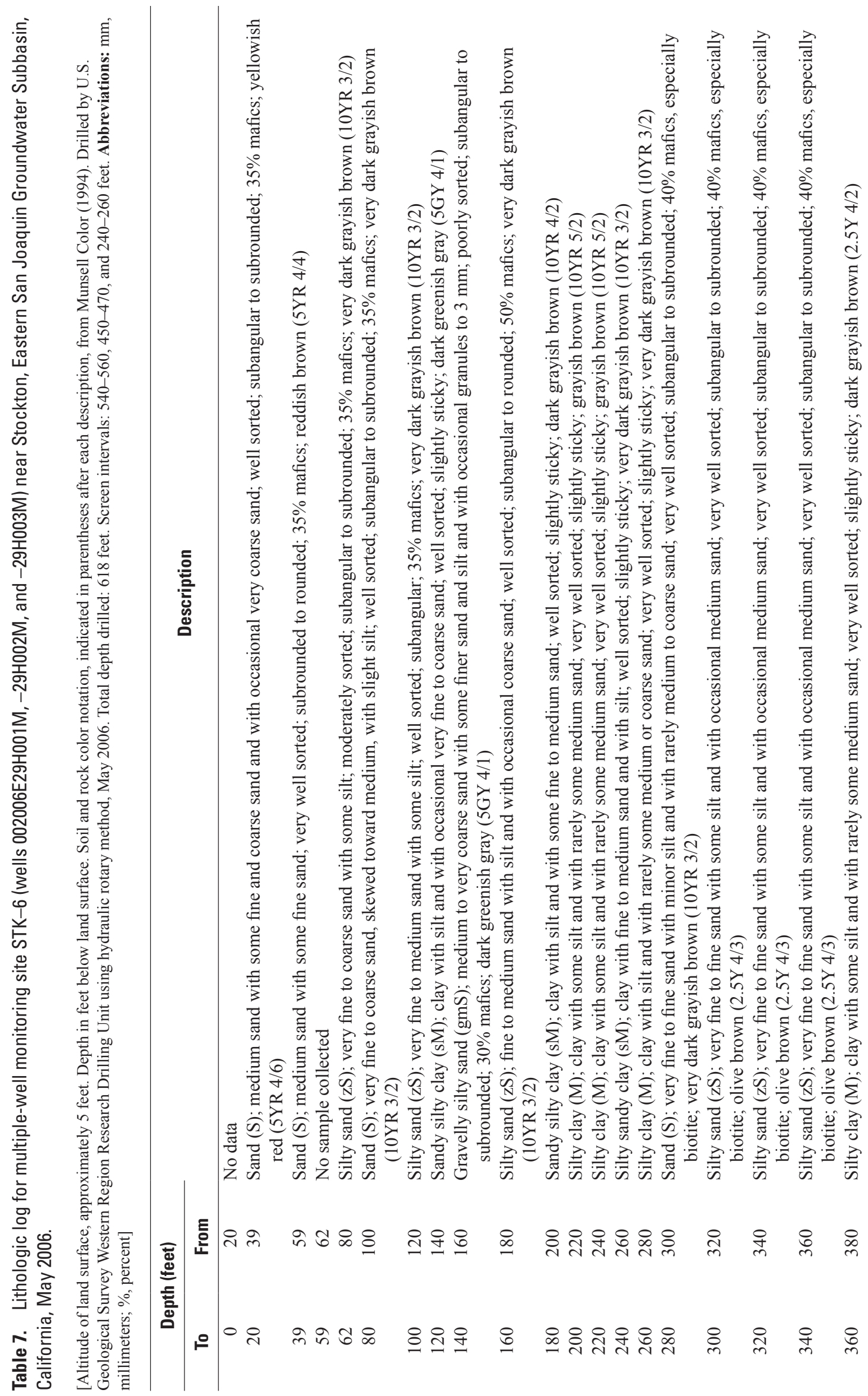




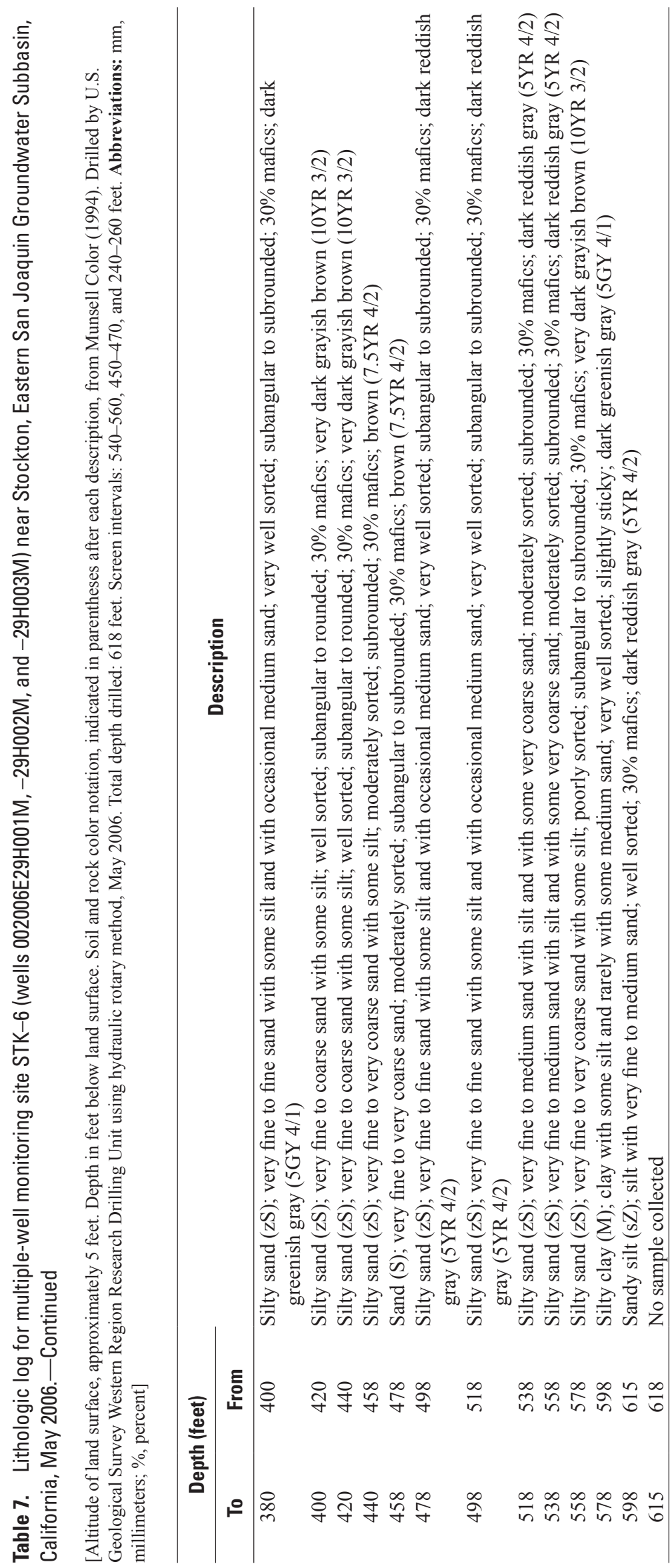




\section{Geophysical Logs}

Borehole geophysical logs for each multiple-well monitoring site were collected from uncased fluid-filled boreholes after drilling and prior to well installation to provide information on the lithologic units and chemical characteristics of the groundwater encountered during drilling. Geophysical logs for selected multiple-well sites are shown in figures $5-\underline{9}$. The geophysical logs generally included: caliper, natural gamma, spontaneous potential (SP), 16-inch and 64-inch electrical resistivity (also known as short or 16-N, and long or 64-N, normal resistivity logs, respectively), and electromagnetic (EM) resistivity logs. These logs are archived in the USGS internal data base, Logarchiver, and are available in electronic form upon request. Only the natural-gamma log could be collected through the steel pipe used to stabilize the borehole after ODEX drilling at the 11H8 site. This log is not shown in this report but is on file at the USGS office in San Diego, Calif.

The caliper tool measures the diameter of the borehole, which changed as the diameter of the drill bit was decreased with increasing drill depth. Unexpected increases in borehole diameter may indicate depths where poorly consolidated sand and (or) gravel have come loose from the sides of the borehole during drilling. These changes may commonly occur at geologic contacts between different aquifer or formation layers. Decreases in borehole diameter may indicate depths where clay has swelled into the borehole or where overlying material that has fallen into the borehole has bridged and partly closed the borehole. This information is needed for placement of well screens, backfill material around well screens, and bentonite seals between well screens during well construction.

The natural-gamma tool measures the intensity of gamma-ray emissions resulting from the decay of naturally occurring radioactive isotopes, which include potassium-40, uranium, and thorium (Schlumberger, 1972). Natural-gamma logs are used to help define lithology, geologic correlation between wells, and the thickness of aquifer layers. Clayrich deposits and feldspar-rich gravels generally emit higher intensity gamma ray than silts or sands. Comparison of the gamma $\log$ and the lithologic $\log$ is necessary to distinguish between clay and gravel deposits that have similar gamma-ray emissions.

The SP tool measures voltage differences that exist between nonporous and porous beds. An SP log usually has a baseline that corresponds to impermeable beds such as clay or shale. Deflections to the left of this baseline correspond to the positions of permeable strata if the formation water is less resistive (more saline) than the drilling mud. Deflections to the right of the baseline correspond to the positions of permeable strata if the formation water is more resistive (less saline) than the drilling mud (Schlumberger, 1972). SP logs can be used to help determine bed thickness, chemical and physical properties, clay content, lithology, and correlation of lithologic units between wells.

The short (16-N) and long (64-N) normal electrical resistivity tools measure the apparent resistivity of a volume of rock under the direct application of an electric current (Keys and MacCary, 1983). These logs are used to determine formation and fluid resistivity and to estimate formation porosity. In an alluvial aquifer system, low resistivity generally indicates water higher in dissolved solids, or fine-grained deposits such as silt, clay, and shale, or both; whereas, high resistivity indicates water lower in dissolved solids, or coarser material, such as sand or gravel, or both. Therefore, resistivity data (coupled with lithologic data) can be used as an indicator of water quality - in general, as dissolved-solids concentration increases, resistivity decreases. For example, the presence of high dissolved-solids water in alluvial deposits could result in a low value of apparent resistivity even if the deposits are composed of sand and gravel. The difference between the short and long normal logs is the separation distance between the electrodes in the tool. As the separation distance increases the volume of aquifer material measured by the tool increases. Comparison of short- and long-normal resistivity values can provide an estimate of the extent to which drilling fluid has entered aquifer deposits during drilling, an indication of the permeability of the aquifer deposits.

The EM tool measures the apparent resistivity of a volume of rock under an induced electromagnetic field. EM logs yield information on lithology of a formation and on chemical characteristics of pore water (McNeil and others, 1990). In alluvial aquifers, EM logs can be interpreted in a manner similar to electrical resistivity logs, where high EM conductivity generally indicates water higher in dissolved solid or fine-grained deposits such as silt, clay, and shale, or both, and low EM conductivity indicates water lower in dissolved solids or coarse-grained material such as sand or gravel, or both. EM logs also can be used to identify changes in water quality in the aquifer outside PVC-cased wells. The application of EM logs for this purpose is discussed later in this manuscript.

The sonic tool, also known as the acoustic or acoustic-velocity tool, is used to measure consolidation and porosity of geologic materials. A sonic log was collected at multiple-well site 002N005E01A002M-01A006M. This log is not presented in this report but is on file at the USGS office in San Diego, California. 


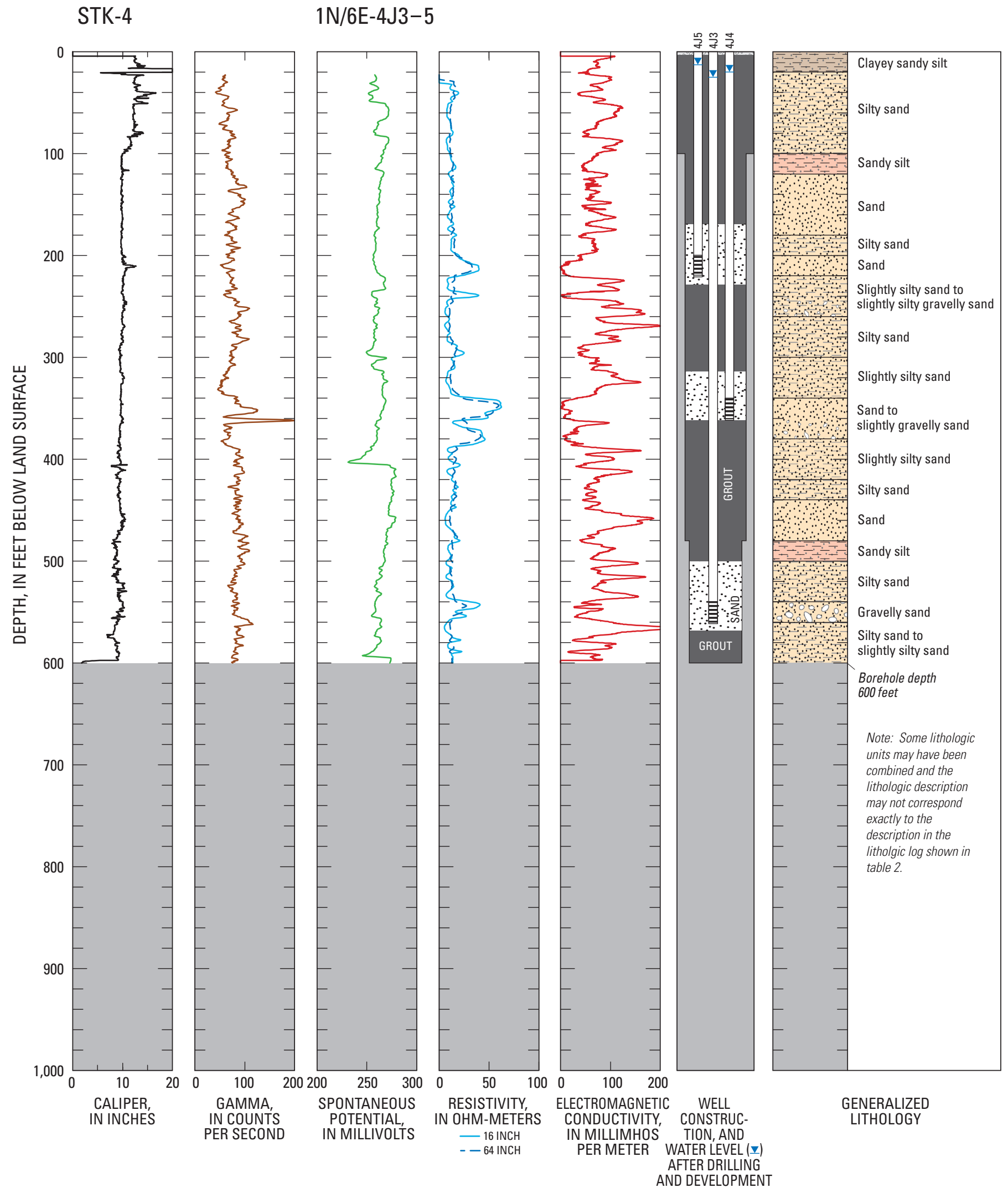

Figure 5. Geophysical logs, lithology, and construction information for multiple-well monitoring site STK-4 (wells 001N006E04J003M, -04J004M, and -04J005M), Eastern San Joaquin Groundwater Subbasin, California. 


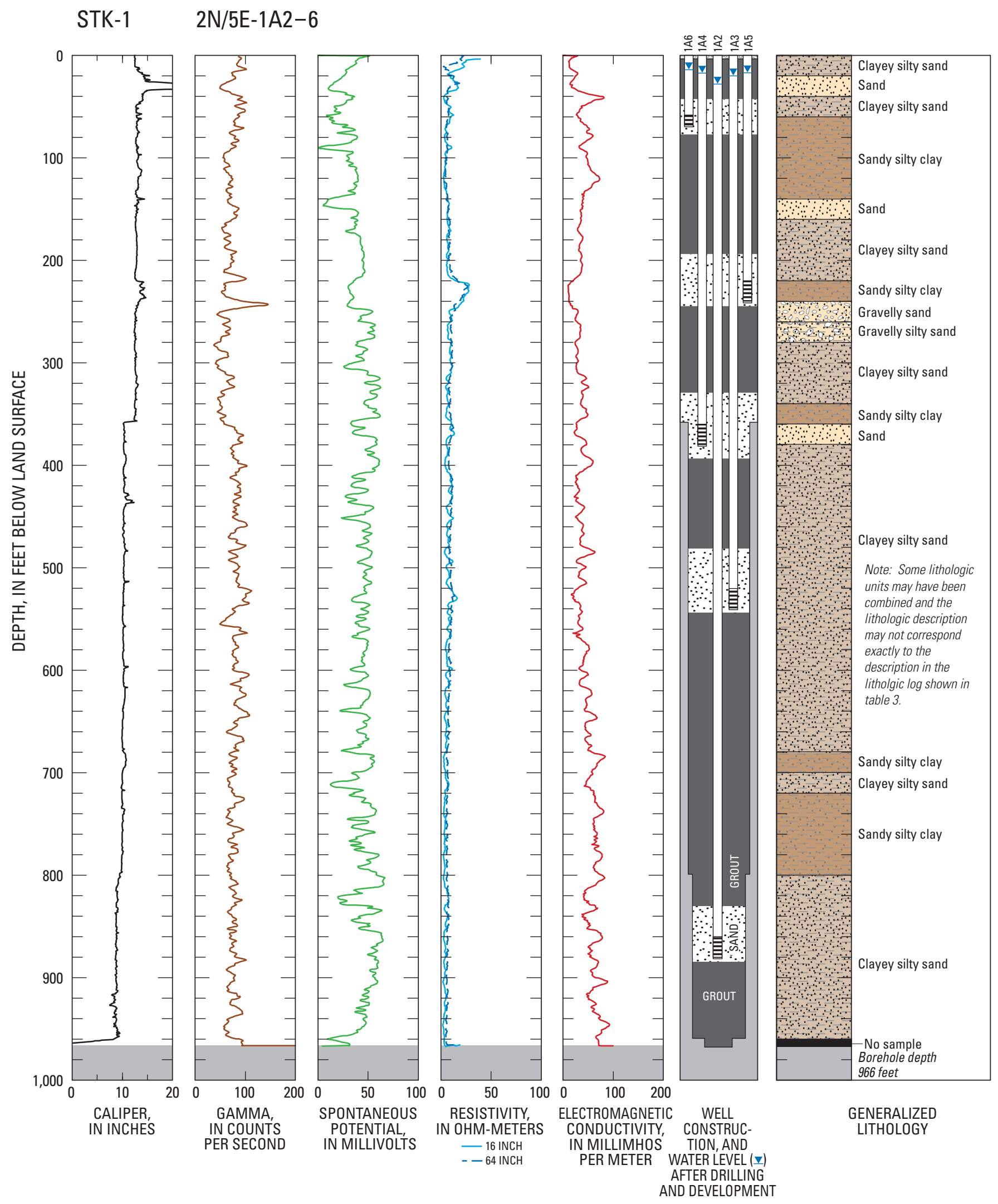

Figure 6. Geophysical logs, lithology, and construction information for multiple-well monitoring site STK-1 (wells 002N005E01A002M, -01A003M, -01A004M,-01A005M, and -01A006M), Eastern San Joaquin Groundwater Subbasin, California. 


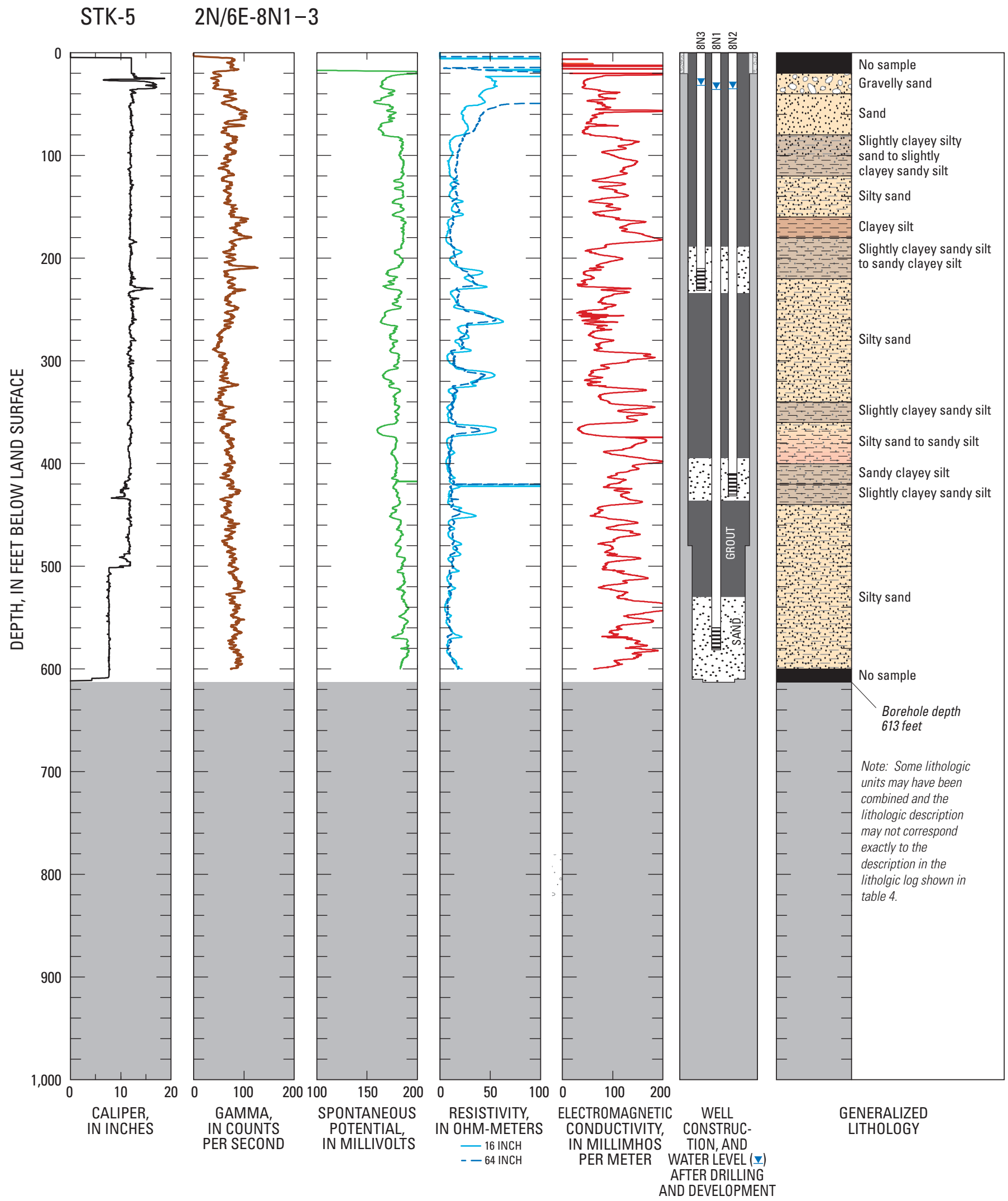

Figure 7. Geophysical logs, lithology, and construction information for multiple-well monitoring site STK-5 (wells 002N006E08N001M, -08N002M, and -08N003M), Eastern San Joaquin Groundwater Subbasin, California. 


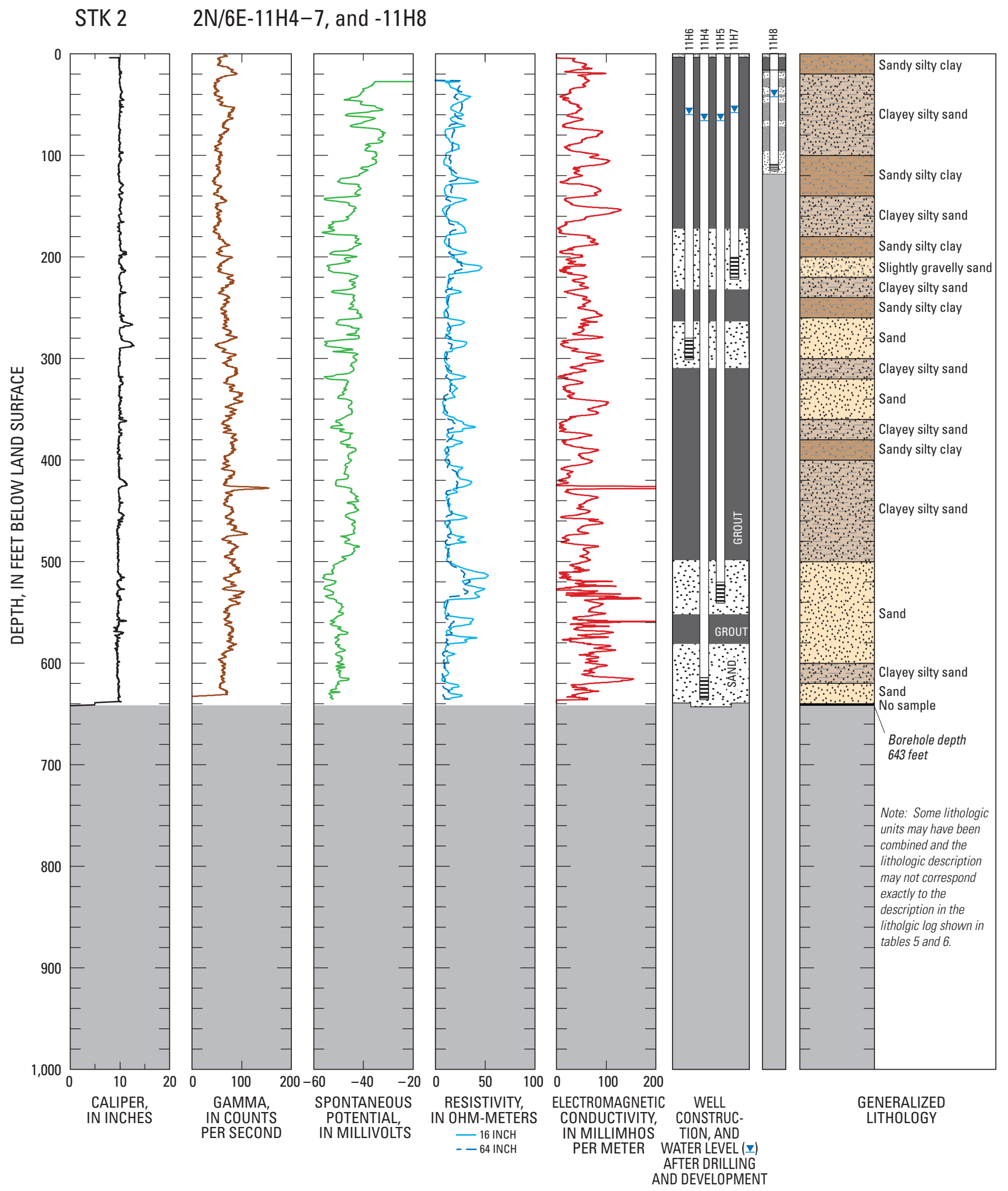

Figure 8. Geophysical logs, lithology, and construction information for multiple-well monitoring site STK-2 (wells 002N006E11H004M, -11H005M,-11H006M,-11H007M and -11H008M), Eastern San Joaquin Groundwater Subbasin, California. 


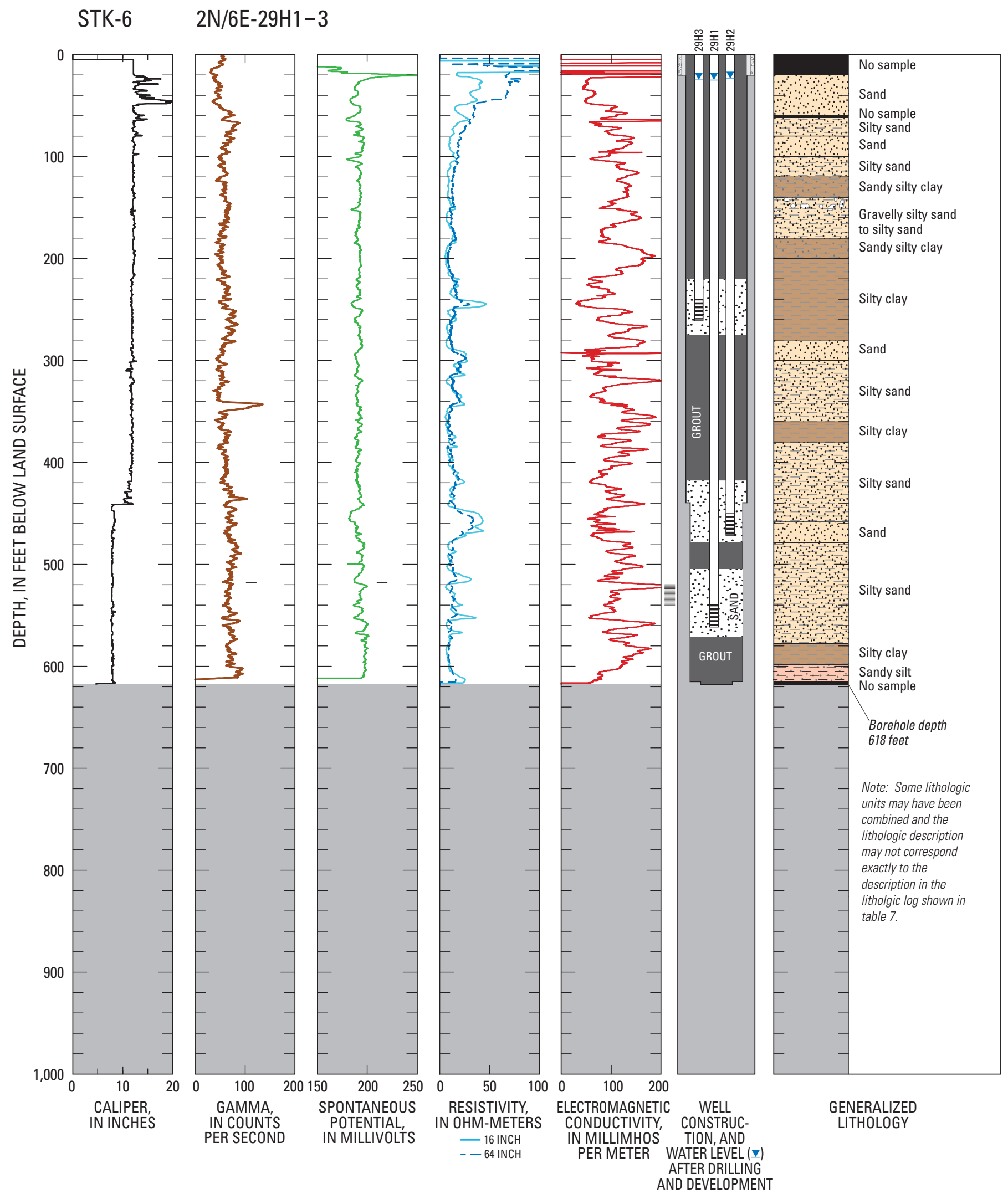

Figure 9. Geophysical logs, lithology, and construction information for multiple-well monitoring site STK-6 (wells 002N006E29H001M, -29H002M, and -29H003M), Eastern San Joaquin Groundwater Subbasin, California. 


\section{Well Construction}

The design of each multiple-well site was based on field notes, inspection of cuttings in the field and office, and analysis of geophysical logs collected after drilling. Multiple-well sites were constructed by installing several 2-inch diameter PVC wells, one at a time, in a single bore-hole. The length of the screened interval of the wells ranged from 10 to $20 \mathrm{ft}$ and consists of 0.02 -inch slots on 0.125 -inch spacing. The total open area for this 2 -inch diameter well screen is 7.6 square inches per foot. Graded sand (Monterrey Sand \#3) was used as the filter pack for well screens at all multiple-well sites. The filter pack was emplaced through a 1-inch diameter tremie pipe. After the filter pack was installed, bentonite grout was pumped into the borehole above the filter pack through a tremie pipe by using a grouter. The process was repeated for each well in the borehole to provide a bentonite seal between wells that prevents water movement vertically through the borehole. Following installation of the uppermost well and filter pack, the borehole was filled with bentonite grout to about $50 \mathrm{ft}$ below land surface, and then the remainder of the borehole was filled with concrete to provide a sanitary seal. Centralizers were used at multiple-well sites 001N006E04J003M-04J005M, 002N006E08N001M-08N003M, and 002N006E29H001M$29 \mathrm{H} 003 \mathrm{M}$ to ensure wells were centralized within, the borehole, and to insured that bentonite seal between individual well casings prevented vertical water movement. Wells were constructed in accordance with County of San Joaquin Public Health Department ordinances and guidelines (San Joaquin County Ordinance Code Section 9-1115.6), and all wells were inspected during drilling and at completion by a county inspector. Well-construction data for multiple-well sites installed as part of this study and for other existing multiple-well sites in the study area are provided in table 1. Well-construction diagrams for five multiple-well monitoring sites installed as part of this study are shown in figures 5-9.

After installation, the individual wells were developed by using compressed air to remove the drilling mud from the well and the aquifer surrounding the well (fig. 10). Development continued until water from the well contained no discernible drilling fluid and the specific conductance of the water had stabilized.

\section{Water-Level Data}

Groundwater levels from 28 wells at 8 selected multiple-well monitoring sites (figs. 11-18) were monitored continuously using pressure transducers at some period of time between January 2006 and August 2008. The sites included wells drilled as part of this study and as part of previous work by the DWR (2003) and by the City of Stockton. Gaps within the hydrographs indicated time periods when the pressure transducer or datalogger were not functioning (table 8).

The data show seasonal differences in water levels with depth and shorter term differences in water levels with depth in response to pumping from nearby wells. Data from multiple-well sites 001N006E04J003M-04J005M, 002N005E01A002M-01A006M, and 002N006E11H004M$11 \mathrm{H} 008 \mathrm{M}$ were transmitted by Geostationary Operational Environmental Satellite (GOES; fig. 19) to the USGS National Water Information System (NWIS) database where they were available for near real-time public access through the USGS National Water Information System Web page (NWISWeb). Data from multiple-well sites 001N006E36C003M-36C005M, 002N006E08N001M-08N003M, 002N006E20E001M20E003M, 002N006E24P001M-24P003M, and 002N006E29H001M-29H003M were retrieved manually during routine servicing and posted to NWIS after field collection. During routine servicing, water levels were measured to an accuracy of $0.01 \mathrm{ft}$ using a calibrated steel tape or a calibrated electric tape. Measured water levels were used to check instrument accuracy and correct for instrument drift, if necessary, prior to posting of the data on NWIS.

All continuous water-level data and measurements collected during routine site servicing are stored in the U.S. Geological Survey Automated Data Processing System (ADAPS) and may be viewed via NWISWeb. 


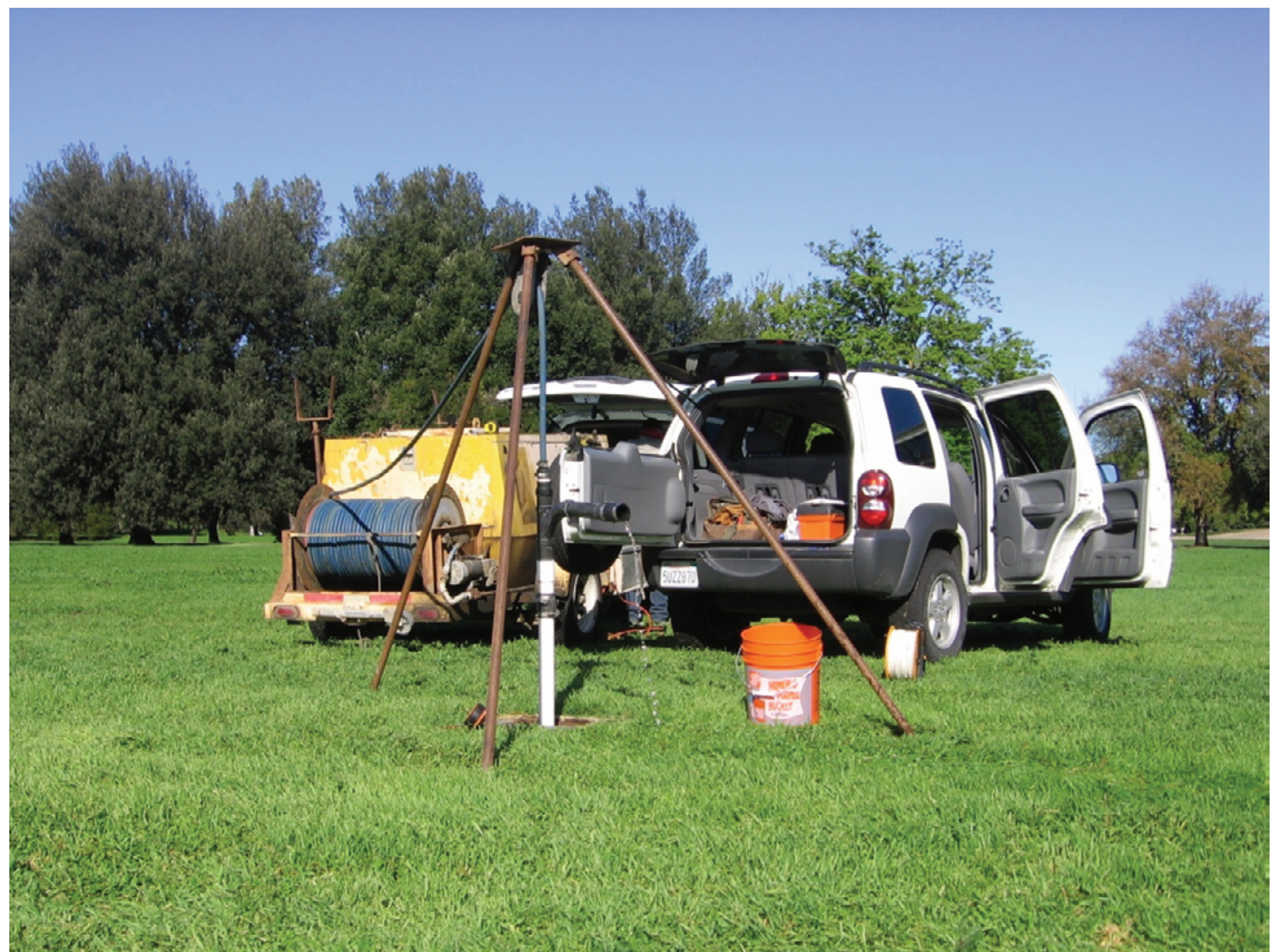

Photograph by Loren Metzger, U.S. Geological Survey, 2007.

Figure 10. Well development using an air compressor at multiple-well monitoring site 002N006E20E001M, -20E002M, and -20E003M (Swenson Park), Stockton, California, March 27, 2007. 
$A$

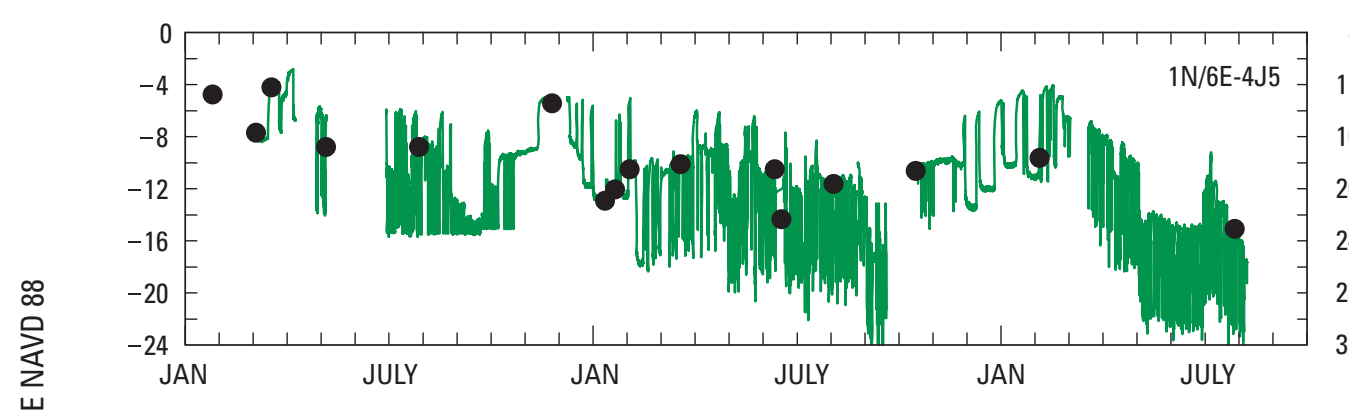

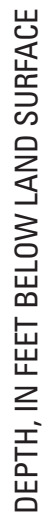

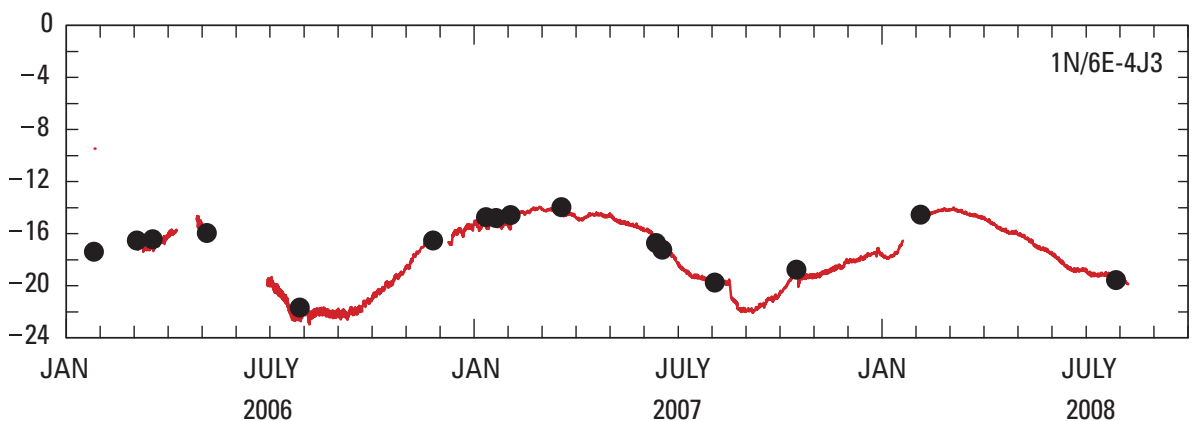

12

16

20

24

DATE

\section{EXPLANATION}

Well number Pressure transducer data Screen interval, in feet below land surface

- Measured water-level data
$4 \mathrm{~J} 5$
200 to 220
$4 \mathrm{~J} 4$
340 to 360
$4 \mathrm{~J} 3$
540 to 560

Figure 11. Water levels for multiple-well monitoring site STK-4 (001N006E04J003M, -04J004M, and -04J005M), Eastern San Joaquin Groundwater Subbasin, California, $(A)$ individual wells, and $(B)$ with depth (grouped on one graph). 


\section{B}

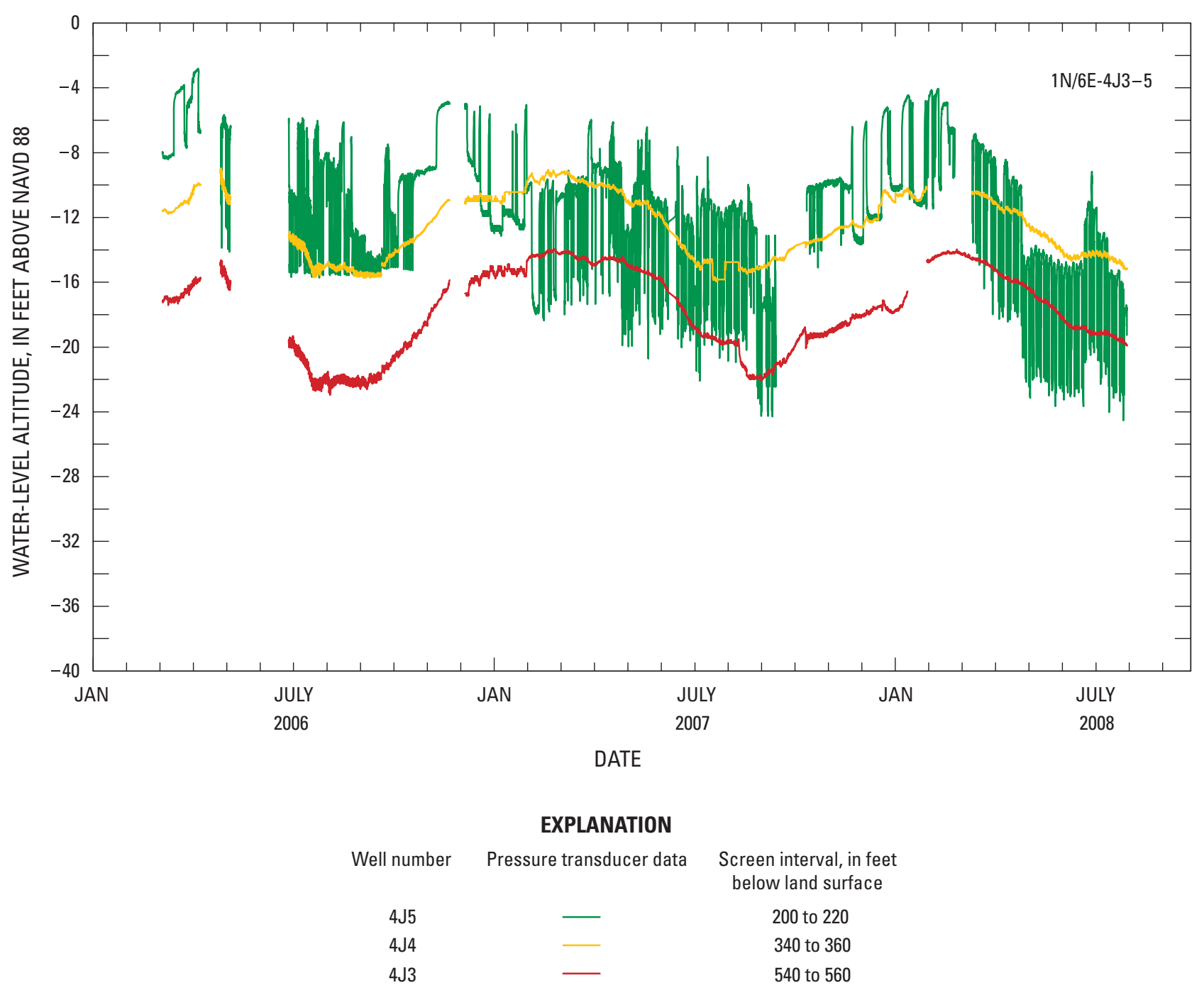

Figure 11.-Continued 
$\boldsymbol{A}$

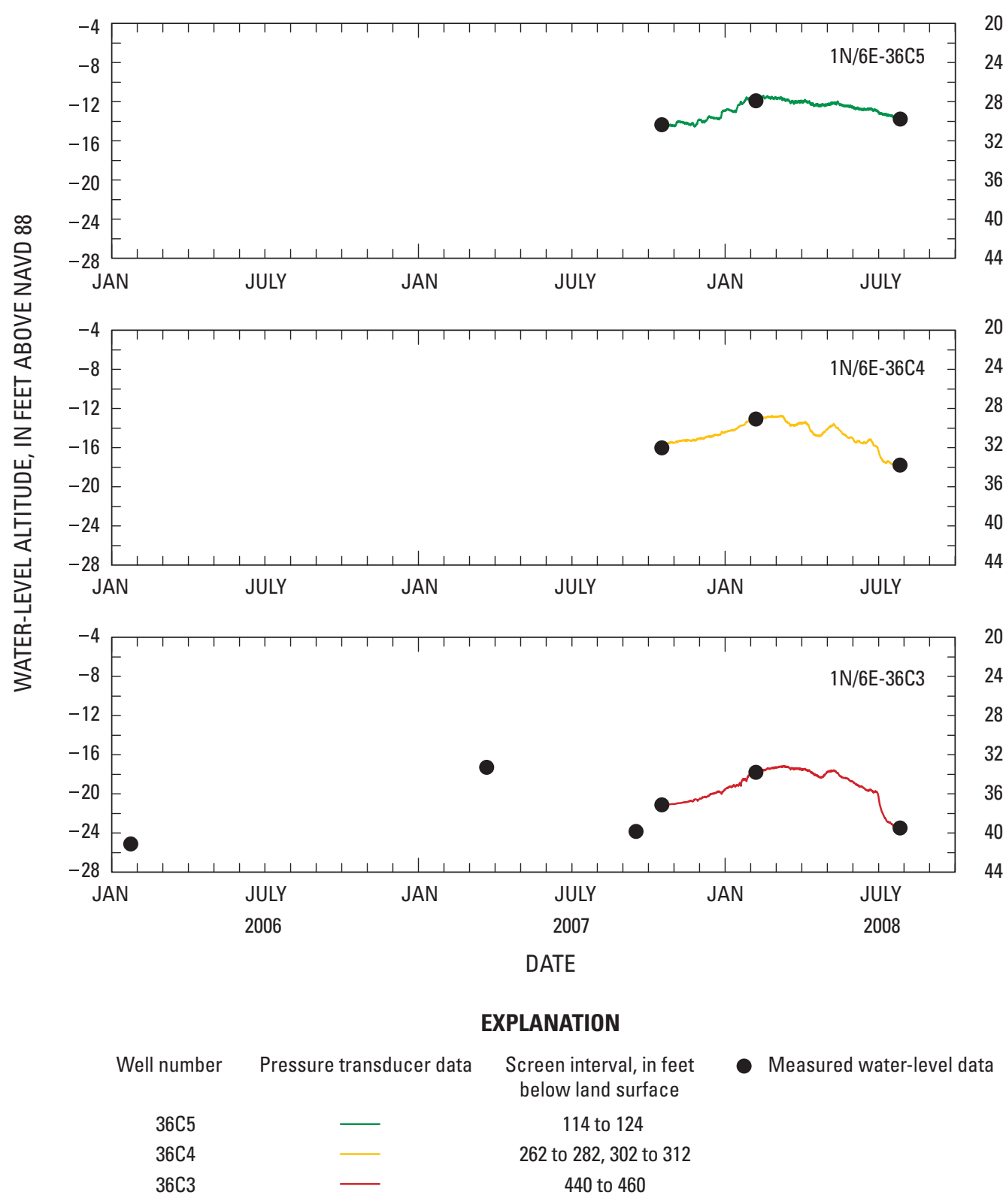

Figure 12. Water-level data for multiple-well monitoring site SPERRY ROAD (001N006E36C003M, -36C004M, and -36C005M), Eastern San Joaquin Groundwater Subbasin, California, $(A)$ individual wells, and $(B)$ with depth (grouped on one graph). 
B

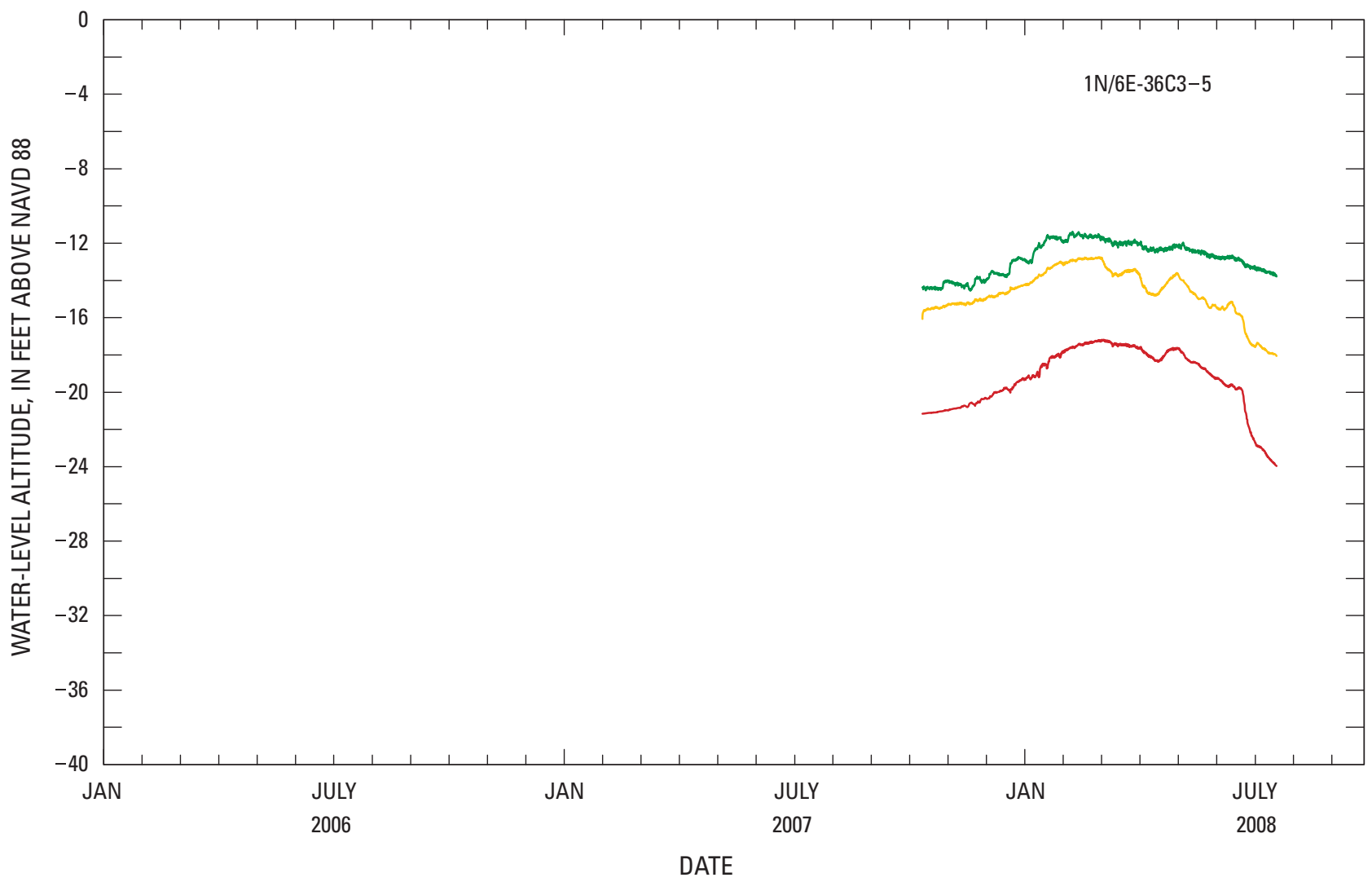

$\begin{array}{ccc}\text { EXPLANATION } & \\ \text { Well number } & \text { Pressure transducer data } & \begin{array}{c}\text { Screen interval, in feet } \\ \text { below land surface }\end{array} \\ \text { 36C5 } & - & 114 \text { to } 124 \\ \text { 36C4 } & - & 262 \text { to } 282,302 \text { to } 312 \\ \text { 36C3 } & - & 440 \text { to } 460\end{array}$

Figure 12.-Continued 


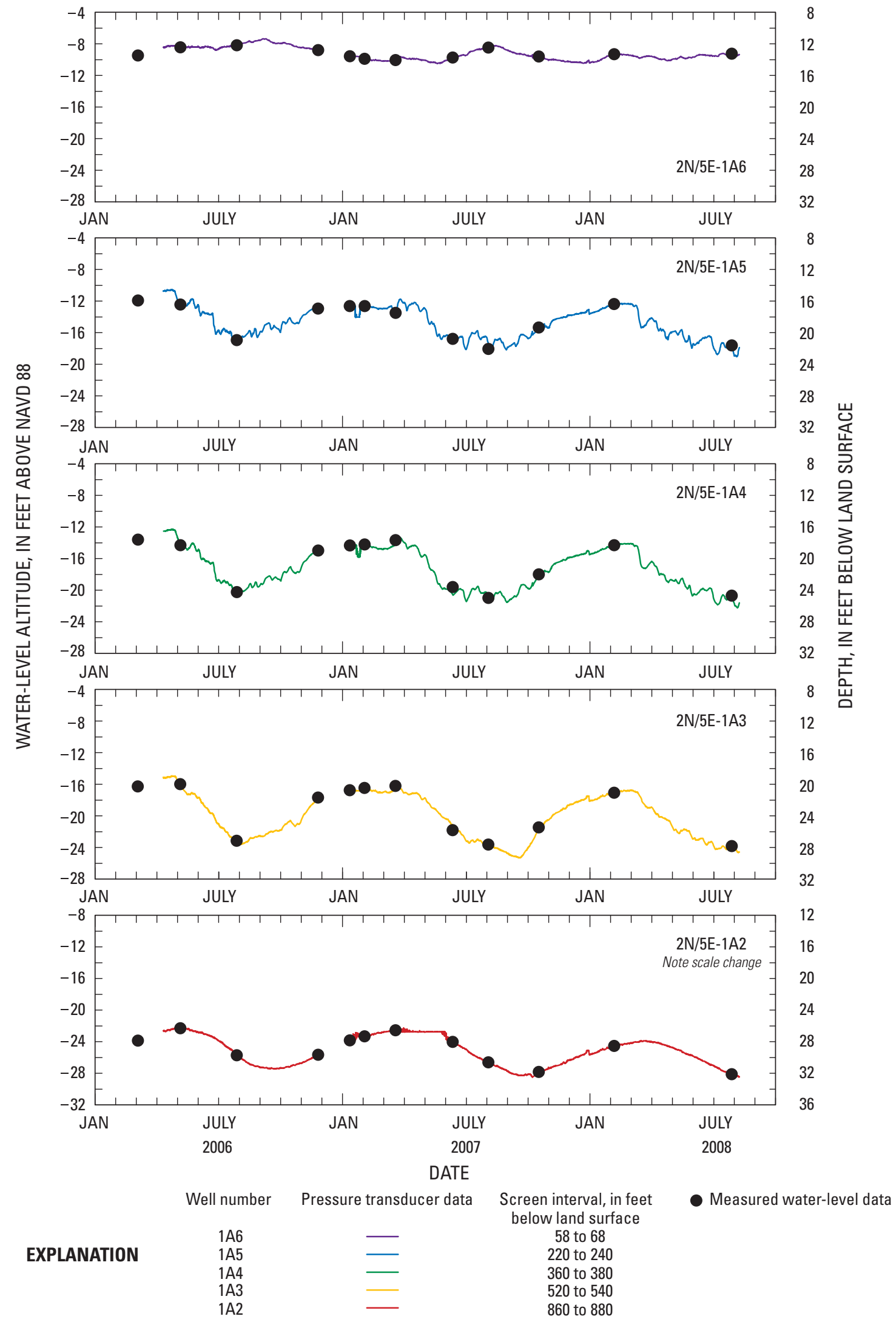

Figure 13. Water levels for multiple-well monitoring site STK-1 (002N005E01A002M, -01A003M, -01A004M, -01A005M, and --01A006M), Eastern San Joaquin Groundwater Subbasin, California, $(A)$ individual wells, and $(B)$ with depth (grouped on one graph). 


\section{B}

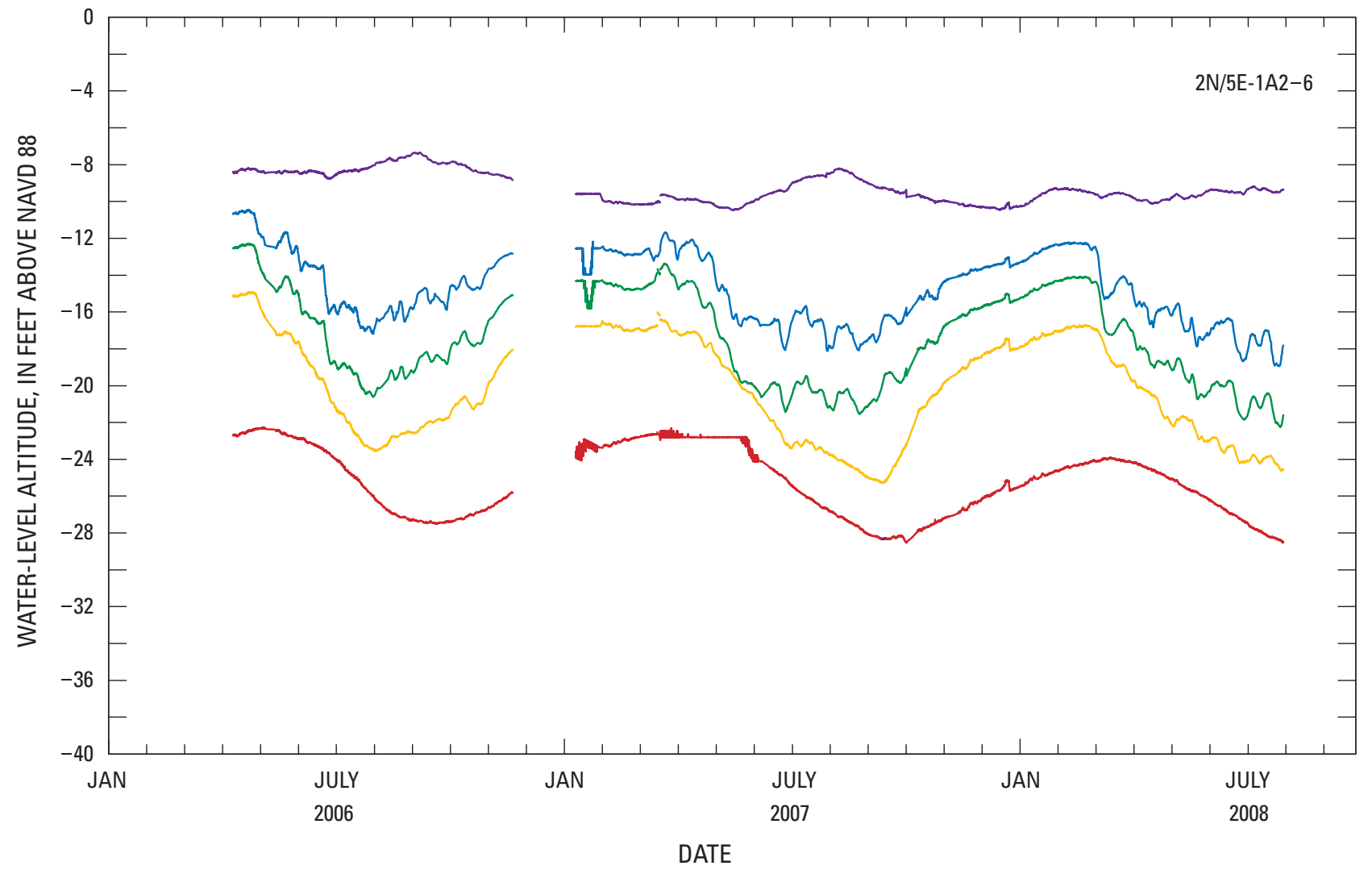

EXPLANATION

Well number Pressure transducer data Screen interval, in feet below land surface

$\begin{array}{llc}\text { 1A6 } & - & 58 \text { to } 68 \\ \text { 1A5 } & 220 \text { to } 240 \\ \text { 1A4 } & - & 360 \text { to } 380 \\ \text { 1A3 } & 520 \text { to } 540 \\ \text { 1A2 } & - & 860 \text { to } 880\end{array}$

Figure 13.-Continued 
A

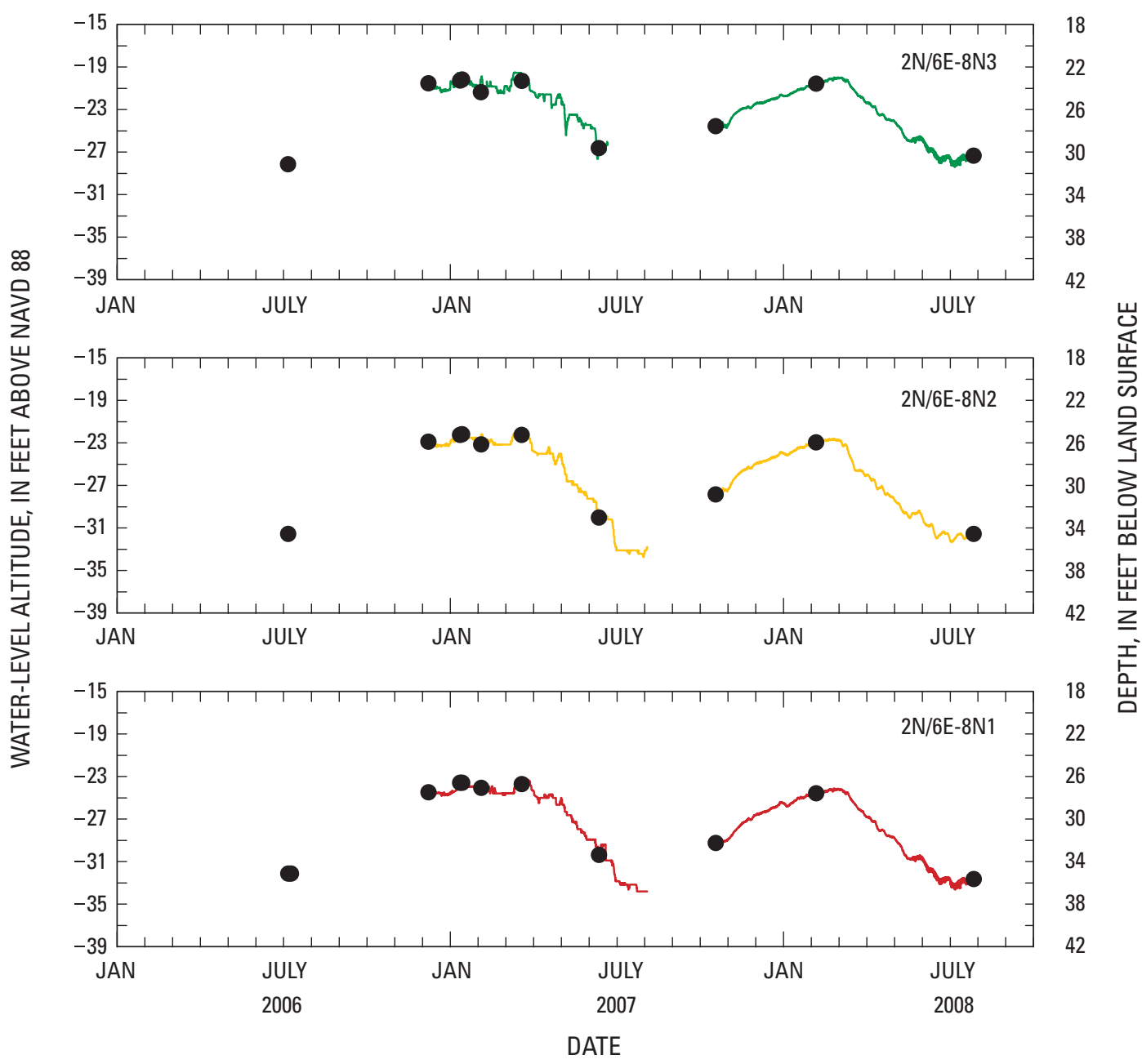

EXPLANATION

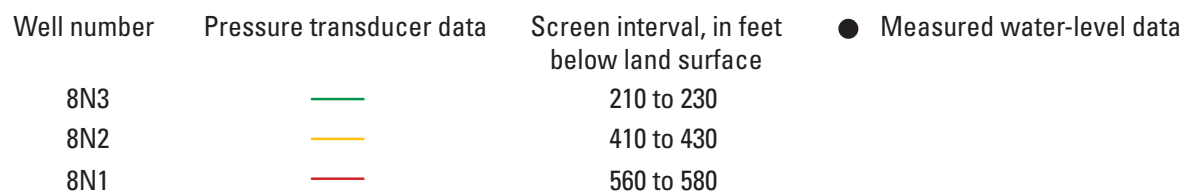

Figure 14. Water levels for multiple-well monitoring site STK-5 (002N006E08N001M, -08N002M, and -08N003M), Eastern San Joaquin Groundwater Subbasin, California, $(A)$ individual wells, and $(B)$ with depth (grouped on one graph). 
B

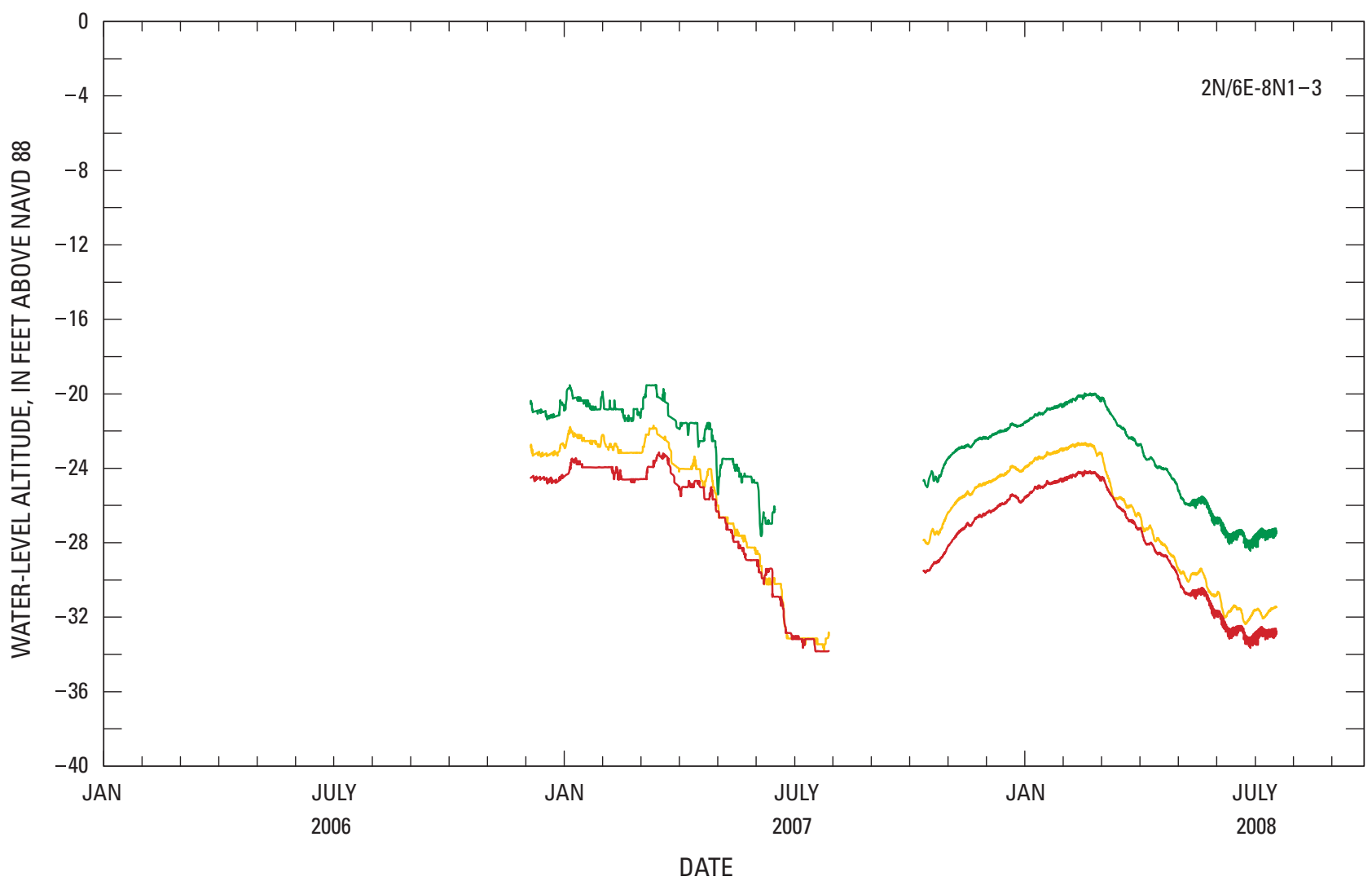

EXPLANATION

Well number Pressure transducer data Screen interval, in feet below land surface

$\begin{array}{lll}8 \mathrm{~N} 3 & - & 210 \text { to } 230 \\ 8 \mathrm{~N} 2 & - & 410 \text { to } 430 \\ 8 \mathrm{~N} 1 & - & 560 \text { to } 580\end{array}$

Figure 14.-Continued 


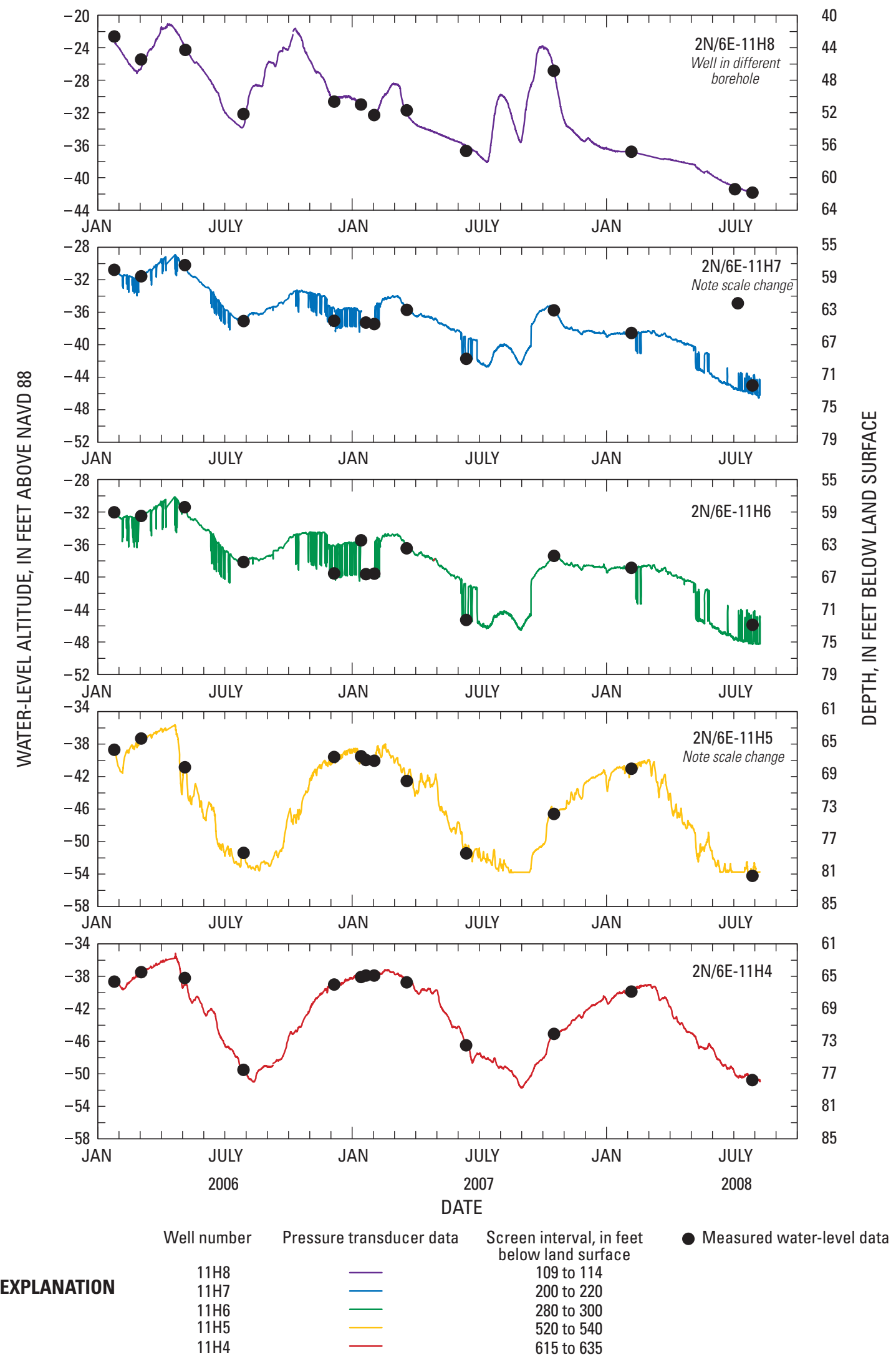

Figure 15. Water levels for multiple-well monitoring site STK-2 and STK-3 (002N006E11H004M, -11H005M,-11H006M,-11H007M and -11H008M), Eastern San Joaquin Groundwater Subbasin, California, $(A)$ individual wells, and $(B)$ with depth (grouped on one graph). 


\section{B}

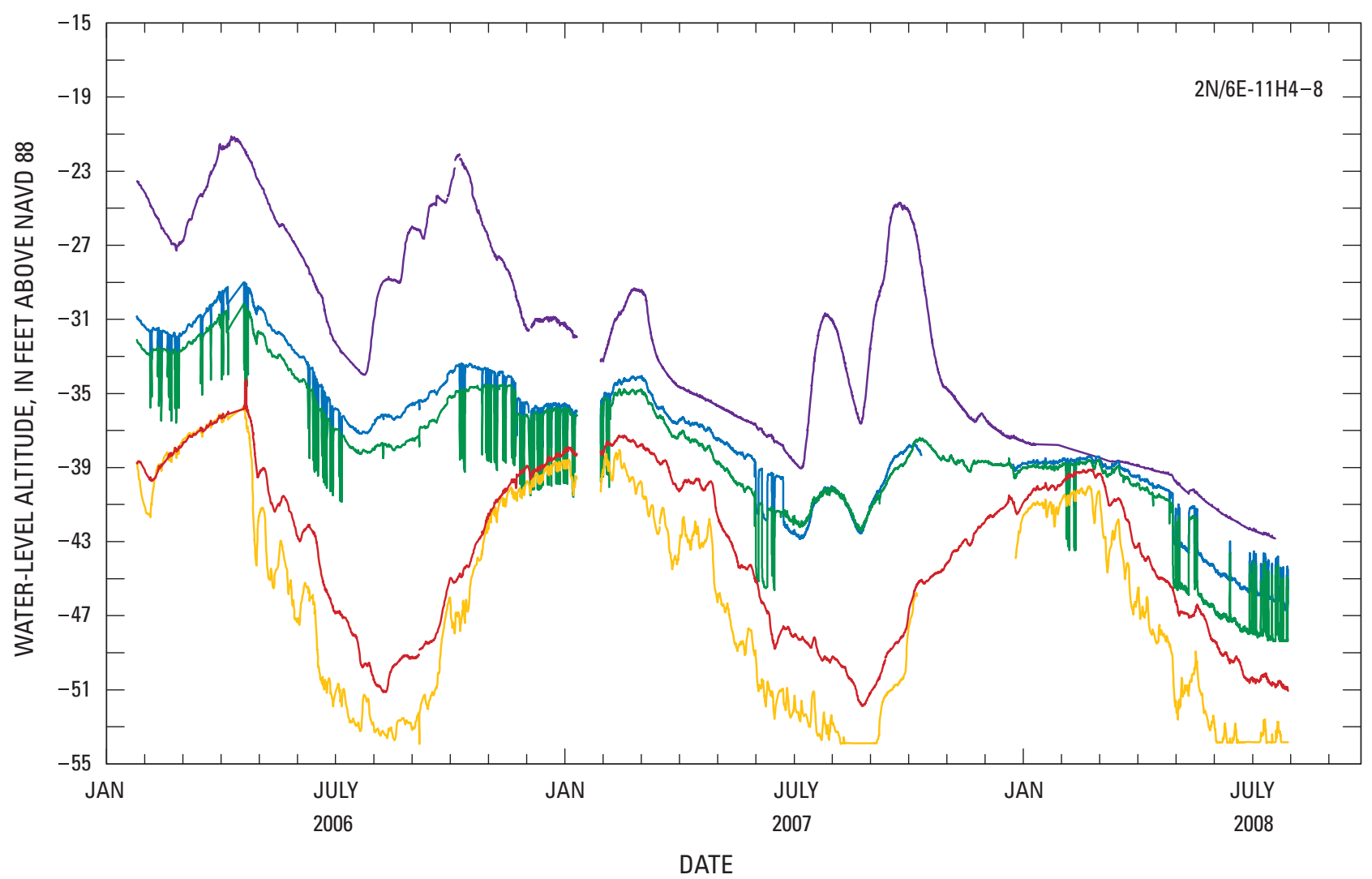

EXPLANATION

$\begin{array}{ccc}\text { Well number } & \text { Pressure transducer data } & \begin{array}{c}\text { Screen interval, in feet } \\ \text { below land surface }\end{array} \\ 11 \mathrm{H} 8 & - & 109 \text { to } 114 \\ 11 \mathrm{H} 7 & - & 200 \text { to } 220 \\ 11 \mathrm{H} 6 & - & 280 \text { to } 300 \\ 11 \mathrm{H} 5 & - & 520 \text { to } 540 \\ 11 \mathrm{H} 4 & - & 615 \text { to } 635\end{array}$

Figure 15.-Continued 
A

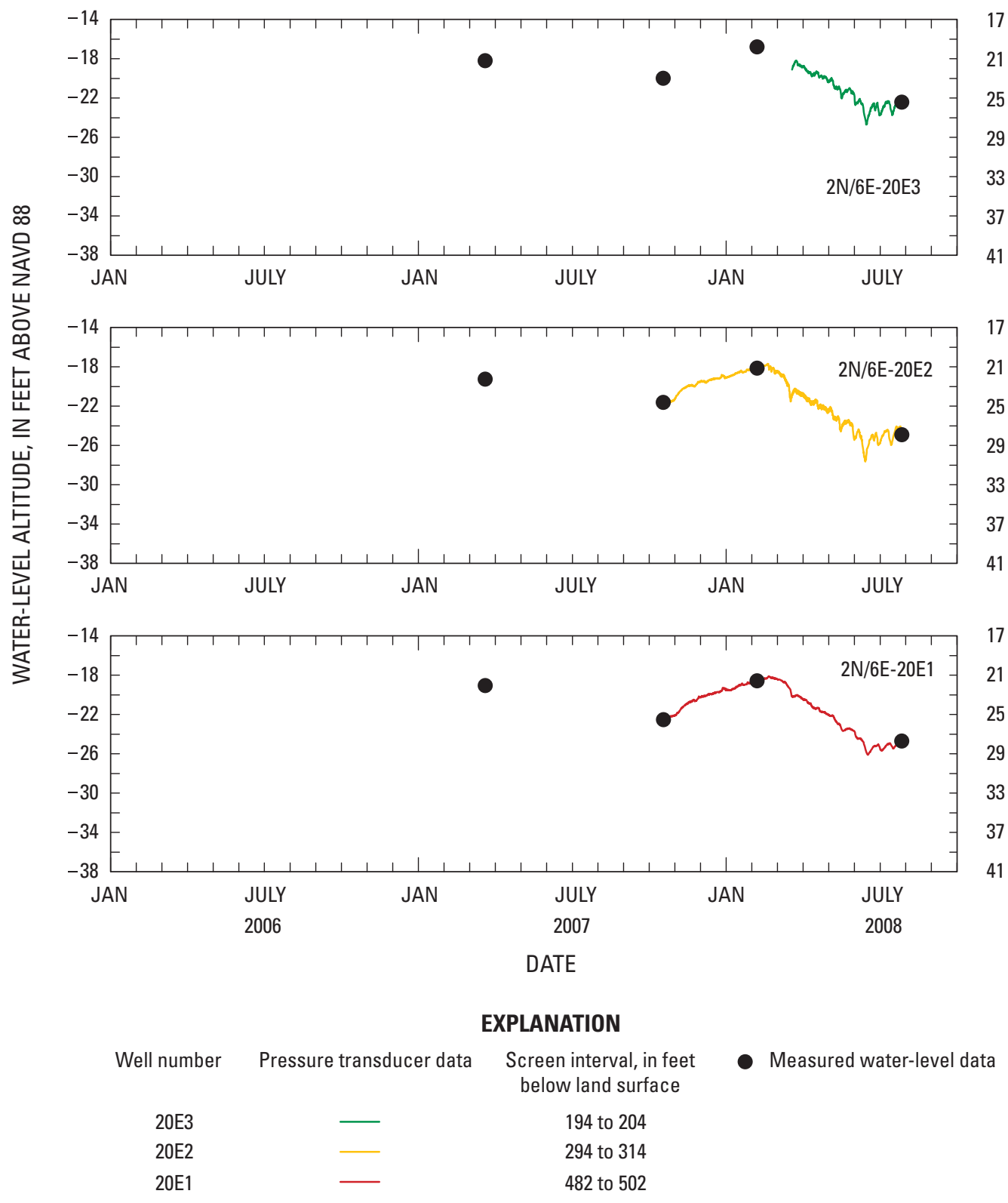

Figure 16. Water levels for multiple-well monitoring site SWENSON PARK (002N006E20E001M, -20E002M, and-20E003M), Eastern San Joaquin Groundwater Subbasin, California, $(A)$ individual wells, and $(B)$ with depth (grouped on one graph). 


\section{B}

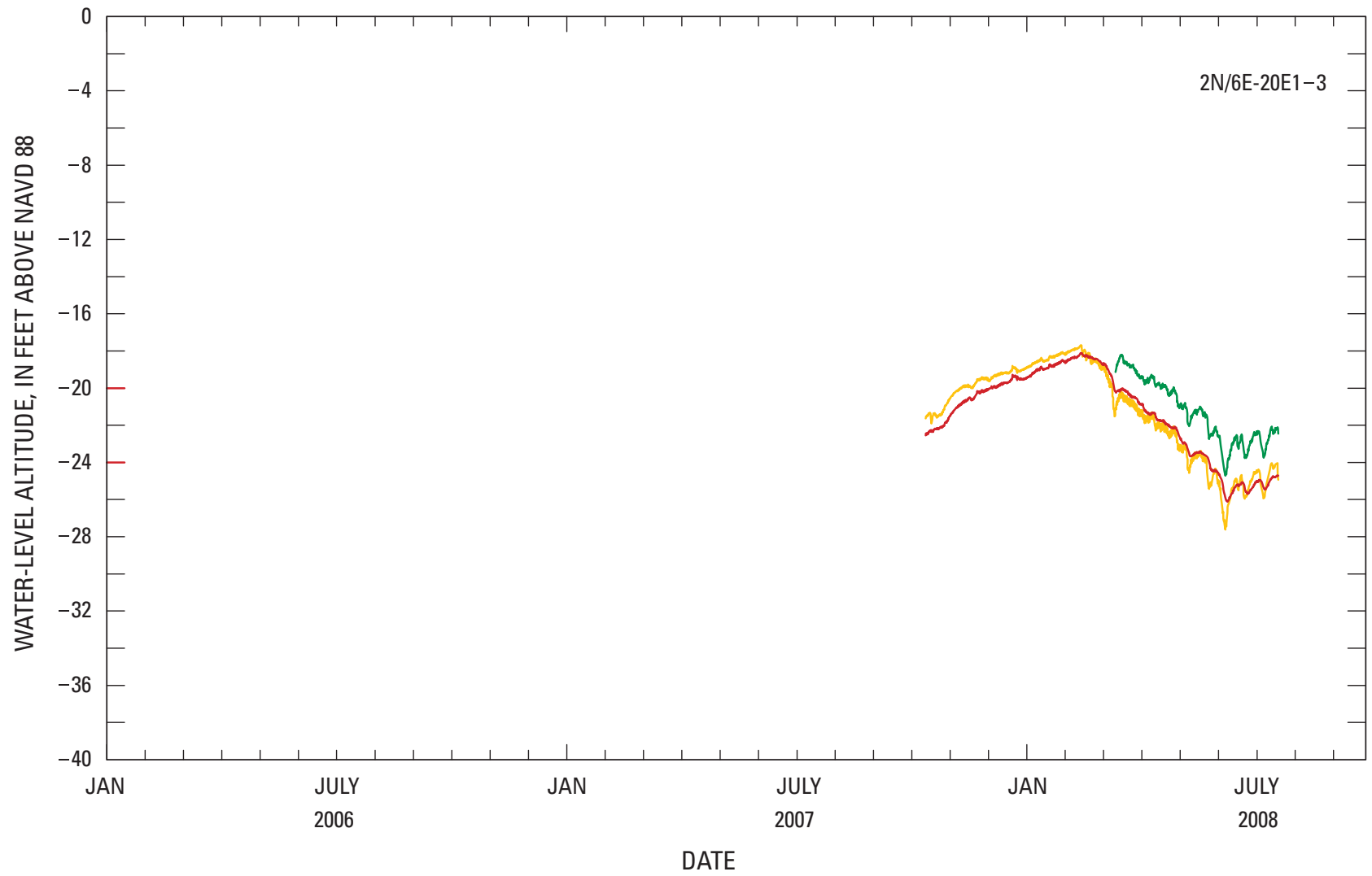

\begin{tabular}{ccc}
\multicolumn{3}{c}{ EXPLANATION } \\
Well number & Pressure transducer data & $\begin{array}{c}\text { Screen interval, in feet } \\
\text { below land surface }\end{array}$ \\
$20 \mathrm{E} 3$ & - & 194 to 204 \\
$20 \mathrm{E} 2$ & - & 294 to 314 \\
$20 \mathrm{E} 1$ & - & 482 to 502
\end{tabular}

Figure 16.-Continued 
A

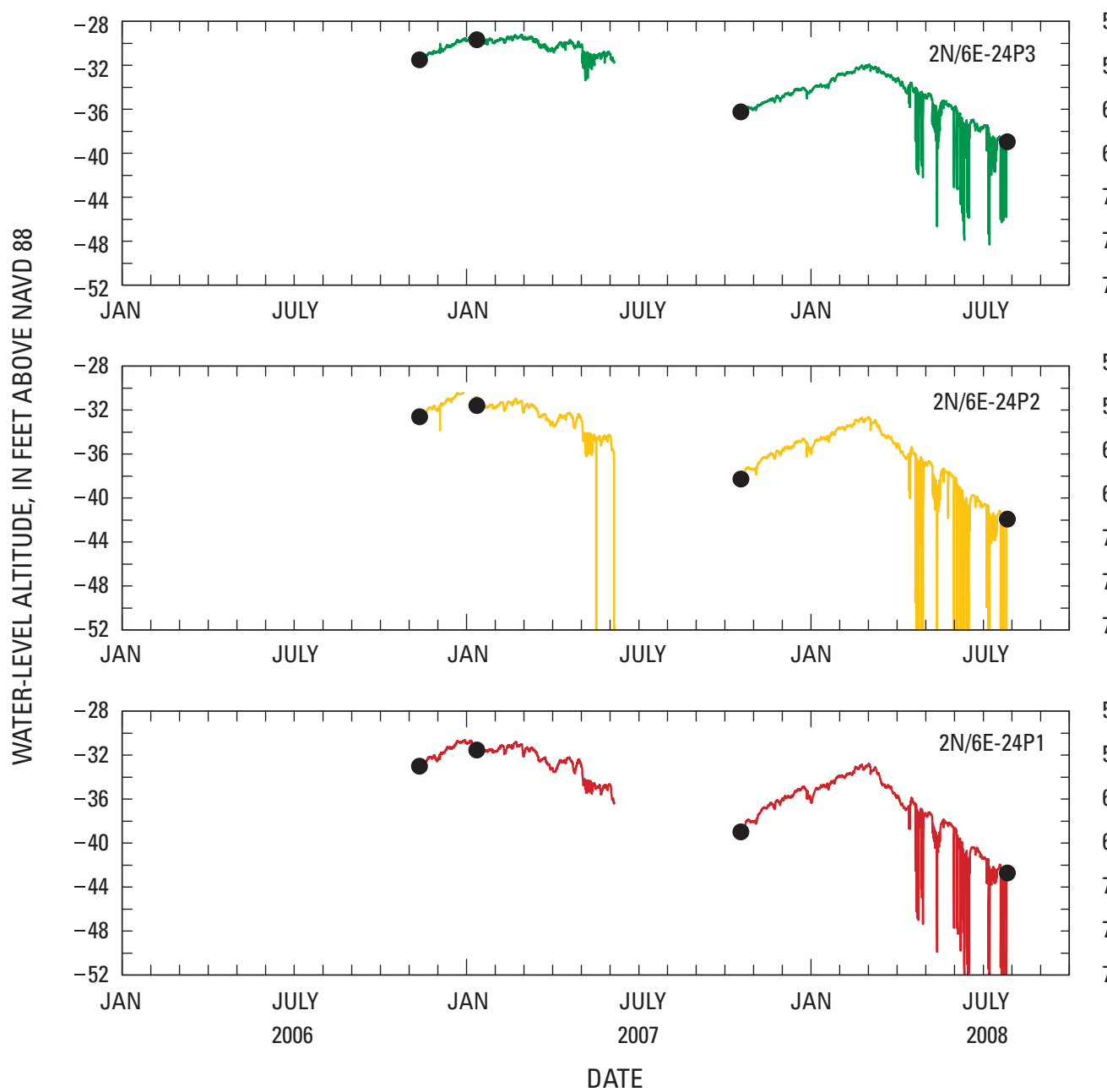

54

58

62

66

70

74

78

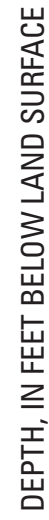

EXPLANATION

Well number Pressure transducer data Screen interval, in feet below land surface
$24 \mathrm{P} 3$
195 to 215
$24 \mathrm{P} 2$
400 to 450
24P1
500 to 520

Figure 17. Water levels for multiple-well monitoring site BLOSSOM RANCH (002N006E24P001M, -24P002M, and -24P003M), Eastern San Joaquin Groundwater Subbasin, California, $(A)$ individual wells, and $(B)$ with depth (grouped on one graph). 


\section{B}

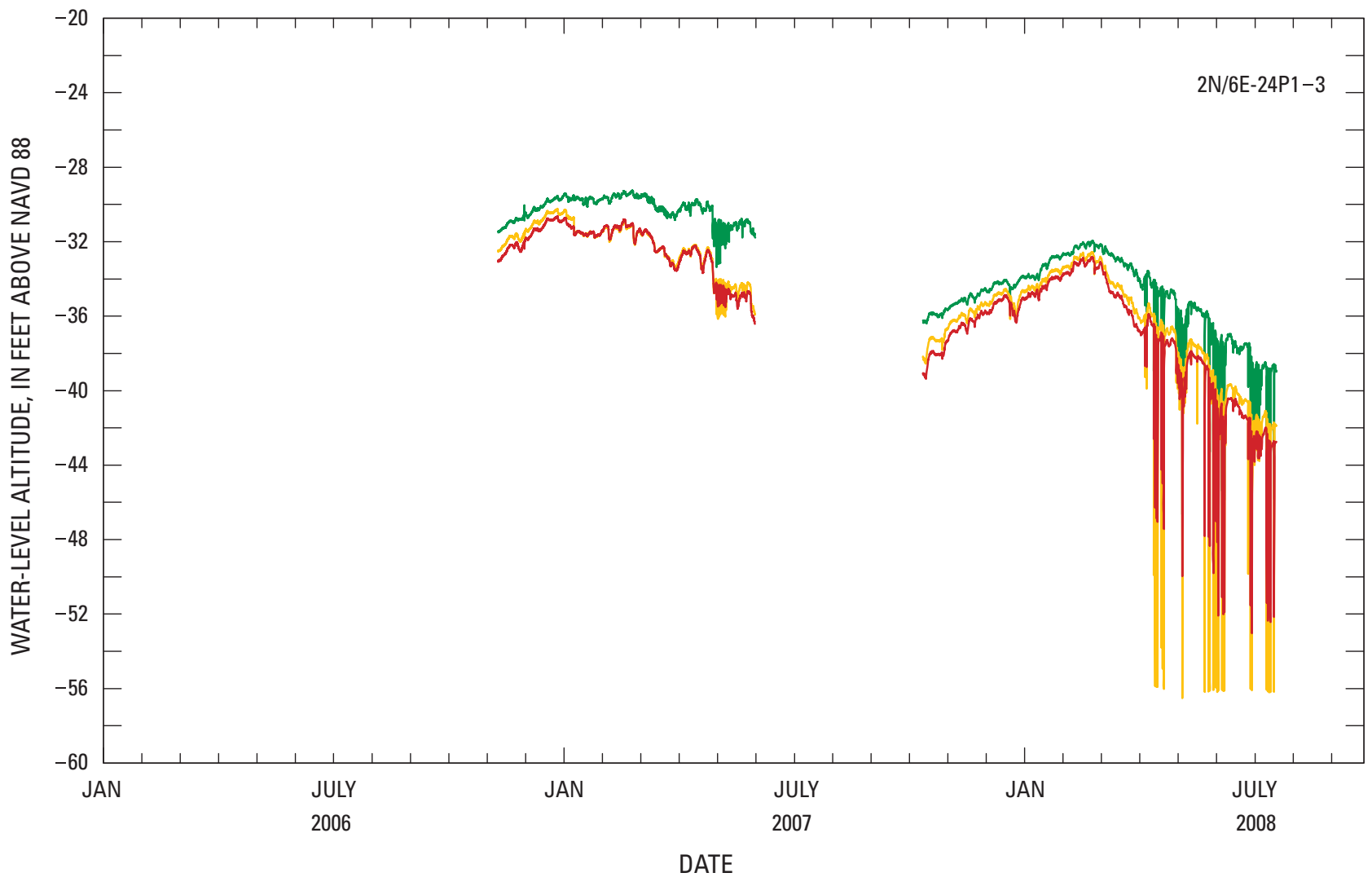

EXPLANATION

Well number Pressure transducer data

Screen interval, in feet

below land surface

$\begin{array}{lll}24 P 3 & & 195 \text { to } 215 \\ 24 P 2 & 400 \text { to } 450 \\ 24 P 1 & - & 500 \text { to } 520\end{array}$

Figure 17.-Continued 
$A$

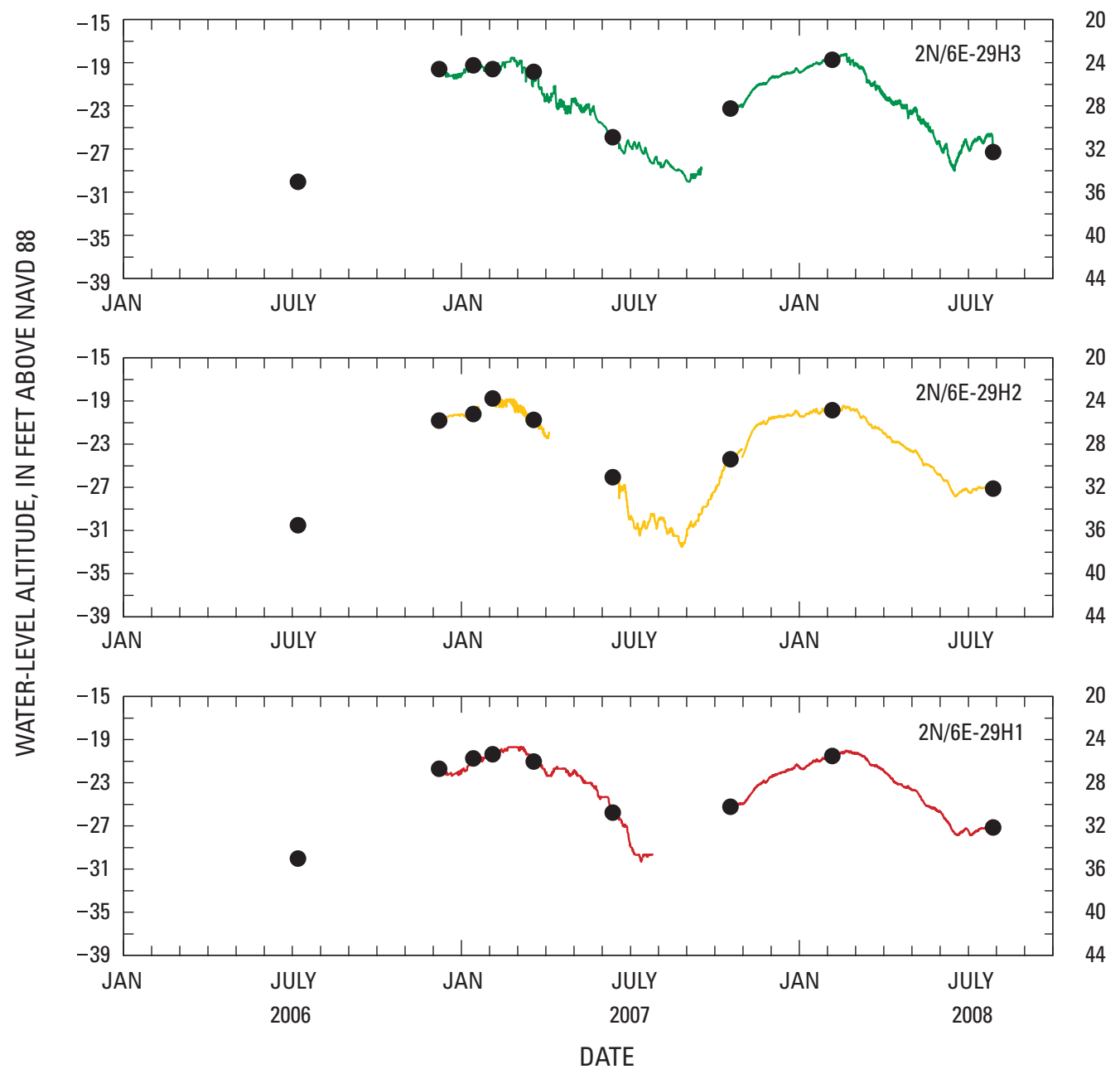

EXPLANATION

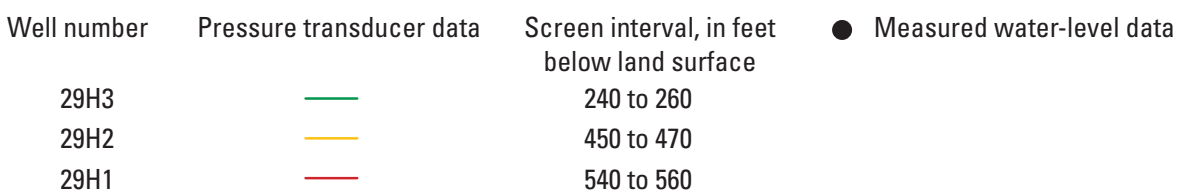

Figure 18. Water levels for multiple-well monitoring site STK-6 (002N006E29H001M, -29H002M, and -29H003M), Eastern San Joaquin Groundwater Subbasin, California, $(A)$ individual wells, and $(B)$ with depth (grouped on one graph). 
B

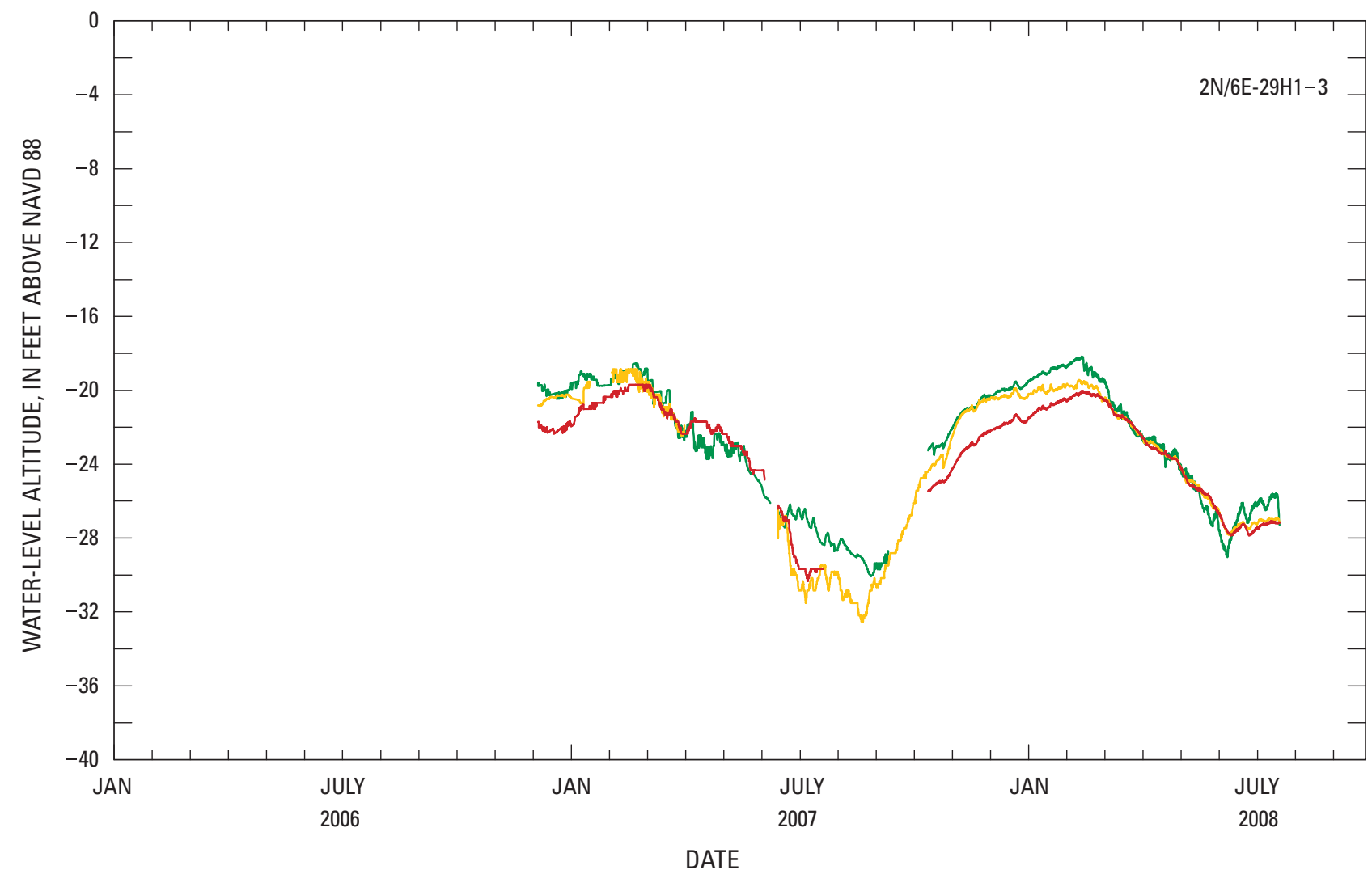

\section{EXPLANATION}

Well number Pressure transducer data Screen interval, in feet below land surface

$\begin{array}{lll}29 \mathrm{H} 3 & - & 200 \text { to } 220 \\ 29 \mathrm{H} 2 & - & 340 \text { to } 360 \\ 29 \mathrm{H} 1 & - & 540 \text { to } 560\end{array}$

Figure 18.-Continued 
Table 8. Transducer recording dates for multiple-well monitoring sites, Eastern San Joaquin Groundwater Subbasin, California.

[Site locations are shown in figure 2. Depths are below land surface. State well number, see well-numbering diagram in text. Well names beginning with STK were drilled by the U.S. Geological Survey. Abbreviations: ft, feet; mm/dd/yy, month/day/year; USGS ID, U.S. Geological Survey identification number: the unique number for each site in USGS National Water Information System (NWIS) database]

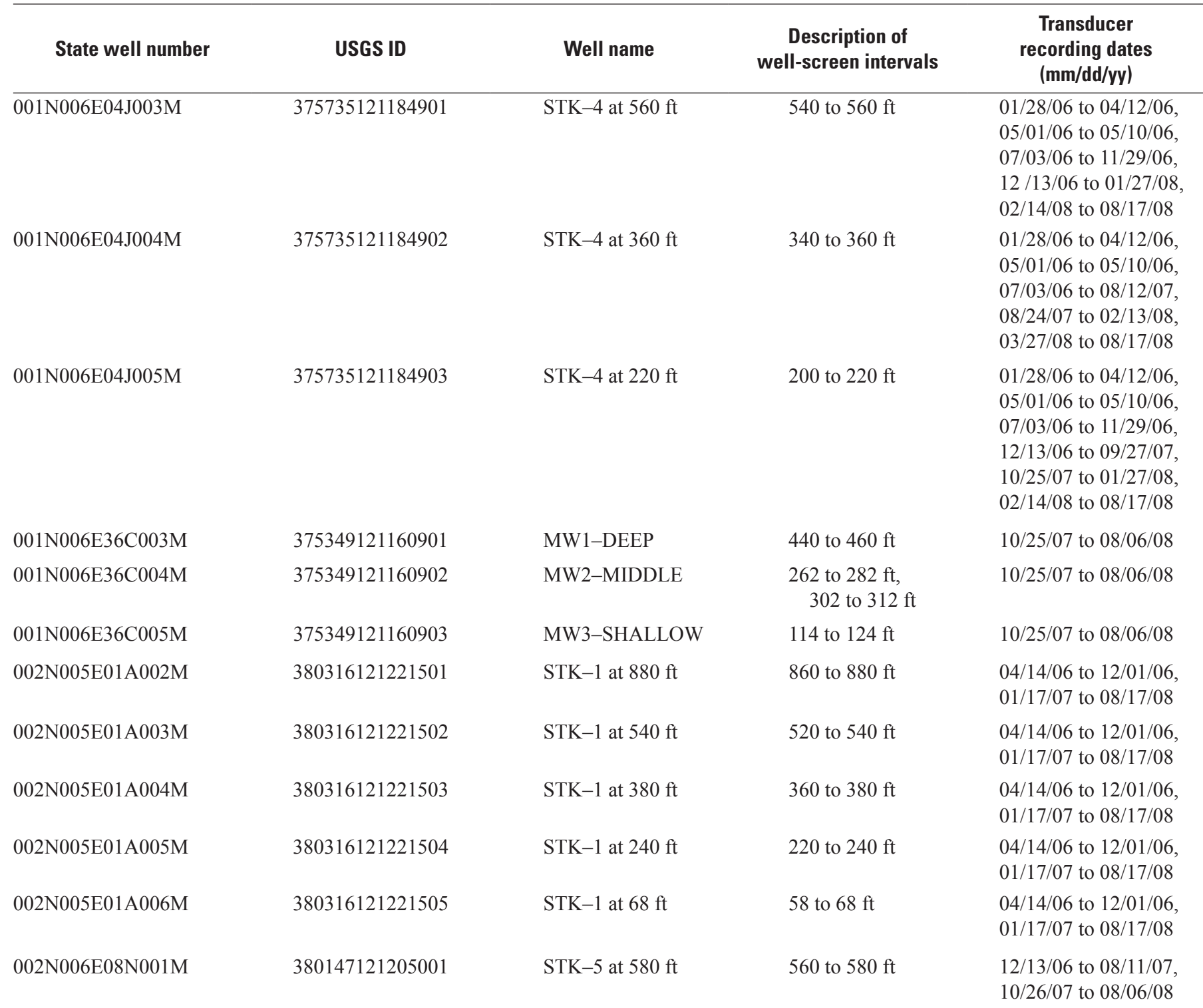


Table 8. Transducer recording dates for multiple-well monitoring sites, Eastern San Joaquin Groundwater Subbasin, California.Continued

[Site locations are shown in figure 2. Depths are below land surface. State well number, see well-numbering diagram in text. Well names beginning with STK were drilled by the U.S. Geological Survey. Abbreviations: ft, feet; mm/dd/yy, month/day/year; USGS ID, U.S. Geological Survey identification number: the unique number for each site in USGS National Water Information System (NWIS) database]

\begin{tabular}{|c|c|c|c|c|}
\hline State well number & USGS ID & Well name & $\begin{array}{c}\text { Description of } \\
\text { well-screen intervals }\end{array}$ & $\begin{array}{l}\text { Transducer } \\
\text { recording dates } \\
\text { (mm/dd/yy) }\end{array}$ \\
\hline 002N006E08N002M & 380147121205002 & STK -5 at $430 \mathrm{ft}$ & 410 to $430 \mathrm{ft}$ & $\begin{array}{l}12 / 13 / 06 \text { to } 08 / 11 / 07 \\
10 / 26 / 07 \text { to } 08 / 06 / 08\end{array}$ \\
\hline 002N006E08N003M & 380147121205003 & $\mathrm{STK}-5$ at $230 \mathrm{ft}$ & 210 to $230 \mathrm{ft}$ & $\begin{array}{l}12 / 13 / 06 \text { to } 08 / 11 / 07 \\
10 / 26 / 07 \text { to } 08 / 06 / 08\end{array}$ \\
\hline 002N006E11H005M & 380209121164102 & STK -2 at $540 \mathrm{ft}$ & 520 to $540 \mathrm{ft}$ & $\begin{array}{l}01 / 27 / 06 \text { to } 01 / 19 / 07 \\
02 / 07 / 07 \text { to } 08 / 07 / 08\end{array}$ \\
\hline 002N006E11H006M & 380209121164103 & $\mathrm{STK}-2$ at $300 \mathrm{ft}$ & 280 to $300 \mathrm{ft}$ & $\begin{array}{l}01 / 27 / 06 \text { to } 01 / 19 / 07 \\
02 / 07 / 07 \text { to } 08 / 07 / 08\end{array}$ \\
\hline 002N006E20E001M & 380026121204401 & MW1-DEEP & 482 to $502 \mathrm{ft}$ & $10 / 26 / 07$ to $08 / 06 / 08$ \\
\hline 002N006E20E002M & 380026121204402 & MW2-MIDDLE & 294 to $314 \mathrm{ft}$ & $10 / 26 / 07$ to $08 / 06 / 08$ \\
\hline 002N006E20E003M & 380026121204403 & MW3-SHALLOW & 194 to $204 \mathrm{ft}$ & $03 / 28 / 08$ to $08 / 16 / 08$ \\
\hline 002N006E24P001M & 380004121160601 & MW1-DEEP & 500 to $520 \mathrm{ft}$ & $\begin{array}{l}11 / 17 / 06 \text { to } 06 / 12 / 07 \\
10 / 26 / 07 \text { to } 08 / 06 / 08\end{array}$ \\
\hline 002N006E24P002M & 380004121160602 & MW2-MIDDLE & 400 to $450 \mathrm{ft}$ & $\begin{array}{l}11 / 17 / 06 \text { to } 06 / 13 / 07 \\
10 / 26 / 07 \text { to } 08 / 06 / 08\end{array}$ \\
\hline 002N006E24P003M & 380004121160603 & MW3-SHALLOW & 195 to $215 \mathrm{ft}$ & $\begin{array}{l}11 / 17 / 06 \text { to } 06 / 12 / 07 \\
10 / 26 / 07 \text { to } 08 / 06 / 08\end{array}$ \\
\hline
\end{tabular}




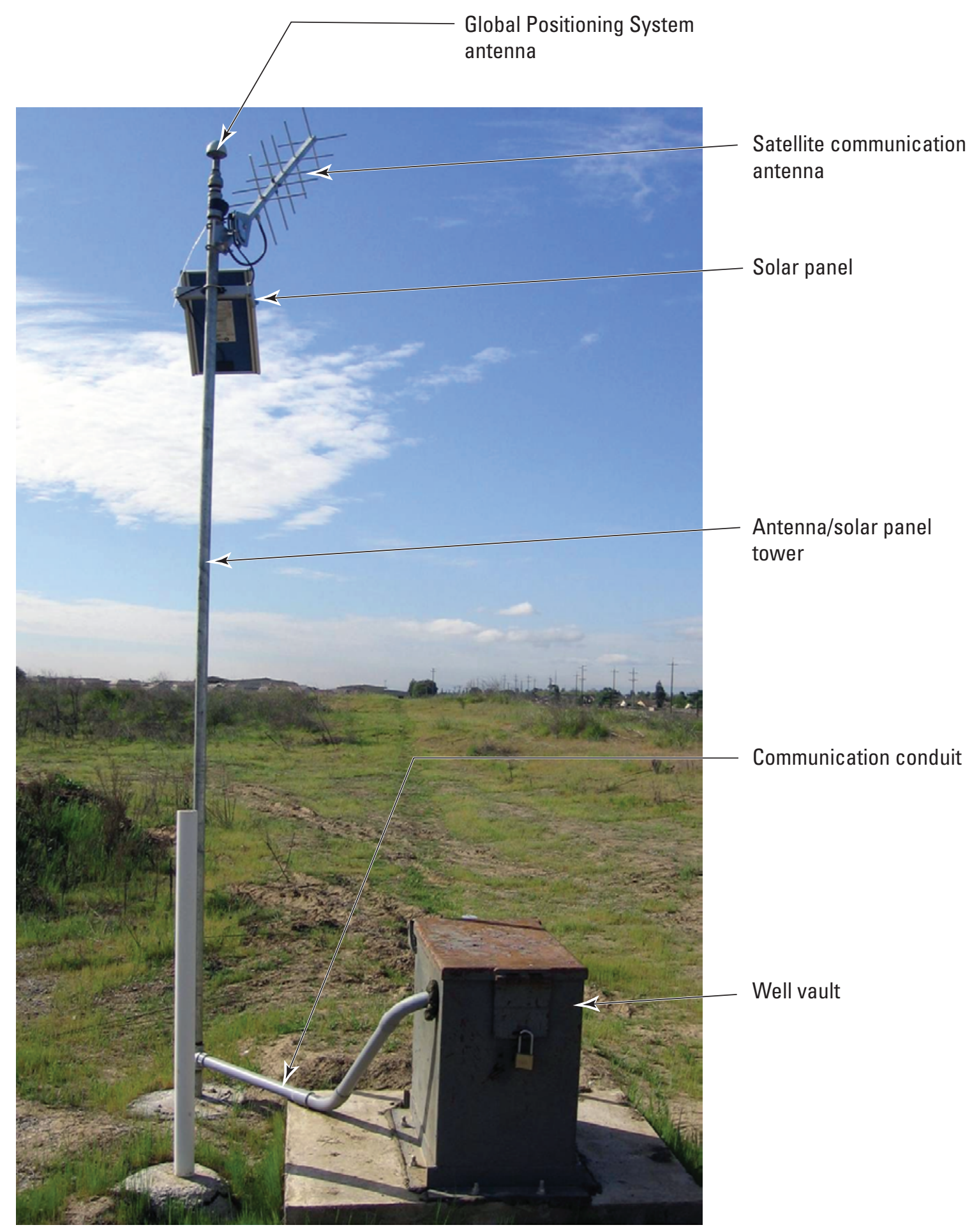

Photograph by David O'Leary, U.S. Geological Survey, 2007.

Figure 19. Data collection and transmission platform located at multiple-well monitoring site 002N006E11H004M, -11H005M, -11H006M, and -11H007M (STK-2), near Morada Lane, Stockton, California, March 26, 2007. 


\section{Geophysical Log Data from Wells}

EM logs were collected from selected PVC-cased monitoring wells to estimate changes in groundwater chemistry at intervals not screened by monitoring wells. Fluid-velocity logs (including fluid temperature and fluid-resistivity logs) were collected from existing public-supply wells under both unpumped and pumped conditions. Fluid-velocity logs collected from wells under pumped conditions were coupled with depth-dependent water-chemistry data collected from discrete depths within the well. Coupled fluid-velocity log data and depth-dependent water-chemistry data were used to evaluate differences in water chemistry with depth.

\section{Electromagnetic (EM) Logs}

Only a limited number of wells screened over selected intervals can be installed at multiple-well monitoring sites. As a consequence, changes in water quality are not measured directly through much of the aquifer thickness. To address this issue, the deepest well at multiple-well sites was used as an access tube for repeated measurement of electromagnetic resistivity through the entire aquifer thickness penetrated by the well. EM logs collected through the PVC casings of monitoring wells are sensitive to lithology and to the resistivity of the pore fluids within the deposits of the formation (McNeil and others, 1990). Because the lithology remains constant with time, repeated EM logs differ only if the fluid resistivity changes as a result of the movement of water of differing quality at depth (Williams and others, 1993). The volume of aquifer material measured by the EM logging tool is a donut-shaped torus having an inner diameter of about 10 inches and an outer diameter of about 50 inches. As a result, the tool is relatively insensitive to borehole fill material adjacent to the well (McNeil and others, 1990). These properties make repeated EM resistivity logs from the same well collected over periods of time suitable for identifying changes in water quality, particularly changes in salinity, at depth intervals from which groundwater samples cannot be collected directly.

The range of conductivity that can be measured using the EM logging tool is 5-3000 millimhos per meter $(\mathrm{mmho} / \mathrm{m})$ with an accuracy of plus or minus 5 percent at $30 \mathrm{mmho} / \mathrm{m}$ (Century Geophysical Corp., 2008). Electromagnetic induction measurements may be affected by borehole size, washouts, and metallic minerals or well construction components such as centralizers (Century Geophysical Corp., 2008). Metal centralizers installed at approximately $29-$ to $59-\mathrm{ft}$ intervals during construction of wells $001 \mathrm{~N} 006 \mathrm{E} 36 \mathrm{C} 003 \mathrm{M}$ and $002 \mathrm{~N} 006 \mathrm{E} 20 \mathrm{E} 001 \mathrm{M}$ created signal interference over approximately 15 percent of the depth of each well, including the bottom 29 and $20 \mathrm{ft}$, respectively. Data from these intervals were omitted prior to data processing and analysis of the EM logs.

To ensure comparability between logs collected at different times, calibration was checked at each site prior to logging by using a 2-point calibration technique. When this technique was used, the tool was suspended upside down in air, and EM resistivity values were measured using free air as the zero value and a calibration-ring sleeve, placed over the bottom end of the inverted tool, having a conductivity of $705 \mathrm{mmho} / \mathrm{m}$. Adjustment to the tool calibration was required if the measured resistivity values exceeded 10 percent of the expected values (Century Geophysical Corp., 2008). At sites where signal interference from nearby cultural artifacts such as overhead power lines, metal fences, and underground utilities made calibration difficult, existing calibration settings from previous logs were retained.

Wells were logged at a speed of about 30 feet per minute $(\mathrm{ft} / \mathrm{min})$ in the upward direction so as to maintain tension on the draw-works cable and to reduce signal noise. The deepest well at each of the multiple-well sites was logged four to five times during the course of the study (table 9). At multiple-well site $002 \mathrm{~N} 006 \mathrm{E} 08 \mathrm{~N} 001 \mathrm{M}-08 \mathrm{~N} 003 \mathrm{M}$, an obstruction in well $002 \mathrm{~N} 006 \mathrm{E} 08 \mathrm{~N} 001 \mathrm{M}$ necessitated the use of the second deepest well at the site (002N006E08N002M) for logs collected in May and September 2007. EM logs collected from PVC-cased wells as part of this study are archived in the USGS internal database, Logarchiver, and are available in electronic form upon request. EM logs collected from fluid-filled boreholes after completion of drilling but prior to installation of the wells were not comparable to logs collected within PVC-cased wells.

Duplicate logs collected over multiple years were collected at 001N006E04J003M in 2006 and in wells 001N006E36C003M, 002N006E08N001M, 002N006E08N002M, 002N006E20E001M, and $002 \mathrm{~N} 006 \mathrm{E} 29 \mathrm{H} 001 \mathrm{M}$ in 2007 to verify the repeatability of measurements (table 9). The R-squared value and coefficient of variation ranged from 0.993 to 0.997 and from 2.32 to 4.46, respectively. 


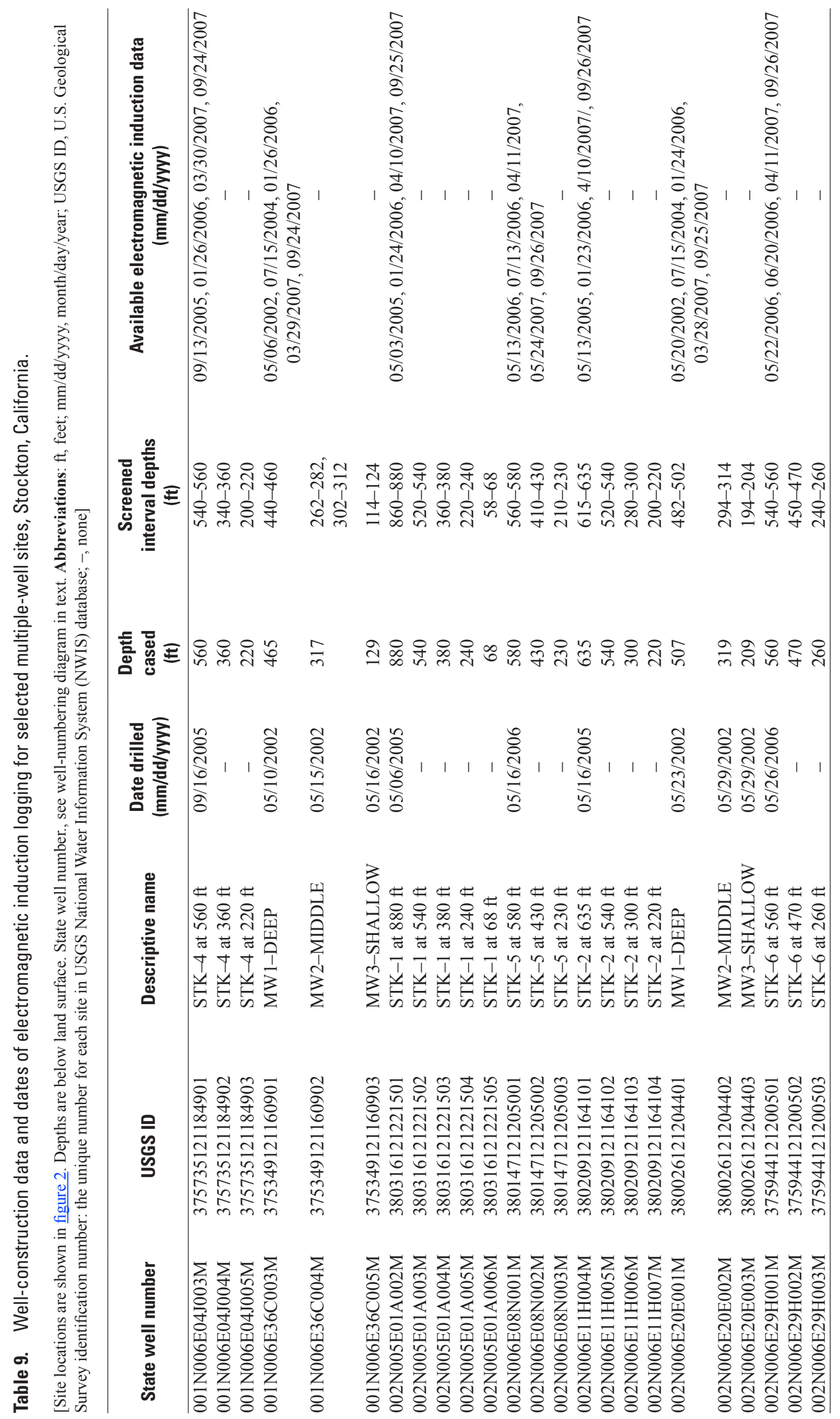




\section{Pumped and Unpumped Fluid-Velocity Logs}

Twenty-three fluid-velocity logs were collected from 14 existing production wells (fig. 20) by using different techniques depending on access to the well. These techniques included (1) commercially available impeller or vertical-axis velocity meters (also known as a spinner tool; Hill, 1990), (2) electromagnetic (EM) velocity meters (Paillet, 2000), or (3) the tracer-pulse method for wells having limited access (Izbicki and others, 1999). Figure 21 shows a typical field setup for collection of a fluid-velocity log using an $\mathrm{EM}$ velocity meter. After collection of the fluid-velocity $\log$, depth-dependent water-chemistry data were collected from selected wells under pumping conditions by using a small-diameter (less than 1 inch) gas-displacement pump (Izbicki, 2004). These data are discussed later in this report in the section titled "Depth-dependent sample collection." Wellbore flow and selected depth-dependent water-quality data was collected while individual wells were pumped and are shown in figures 22-33. Data for unpumped conditions are shown in figures 34-44. On these figures negative flow values represent downward flow within the well and positive values represent upward flow.

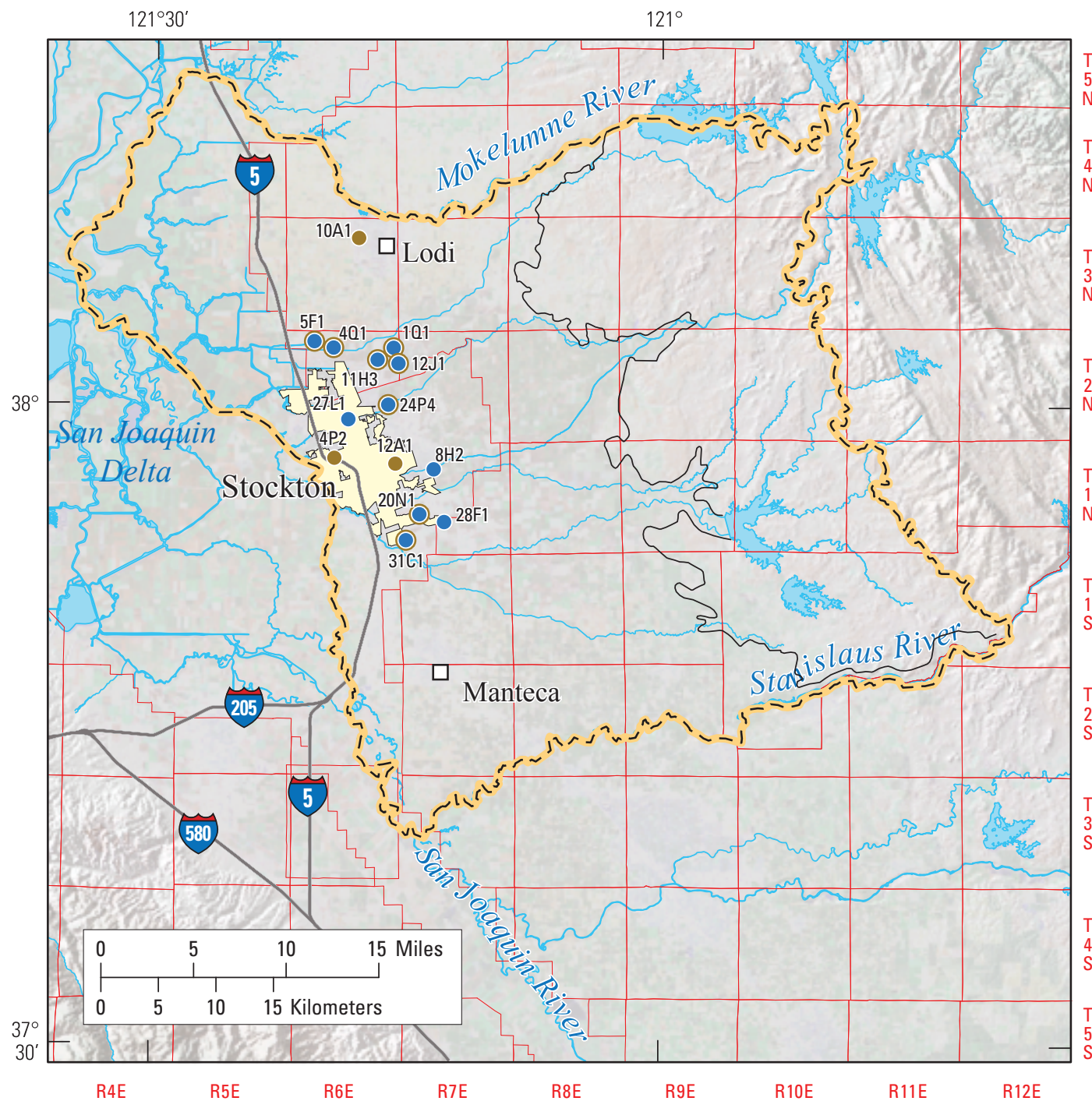

\section{EXPLANATION}

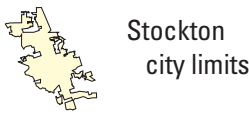

Eastern San Joaquin

Groundwater

Subbasin
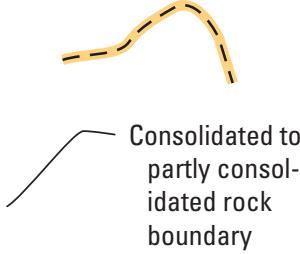

$11 \mathrm{H}_{3} \bigcirc$ Pumped well and well number

12A1 Unpumped well and well number

24P4 $\bigcirc$ Pumped/unpumped well and well number

Figure 20. Locations of study area and well sampling sites for depth-dependent water chemistry coupled with pumped and unpumped fluid-velocity logs, Eastern San Joaquin Groundwater Subbasin, California. 


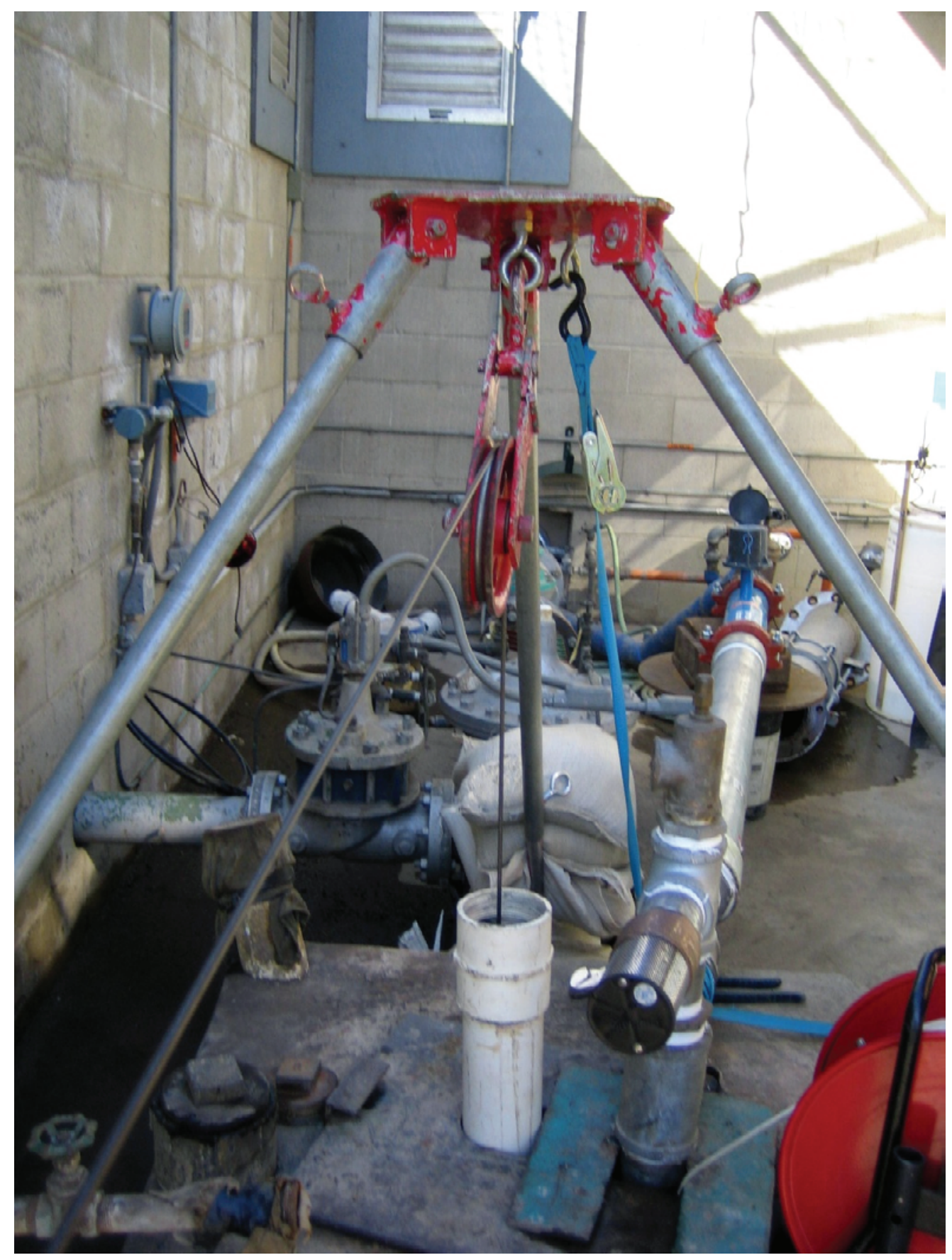

Photograph by Loren Metzger, U.S. Geological Survey, 2008.

Figure 21. Electromagnetic flowmeter logging, City of Stockton well 001N007E31C001M (SSS-5), Stockton, California, March 20, 2008. 

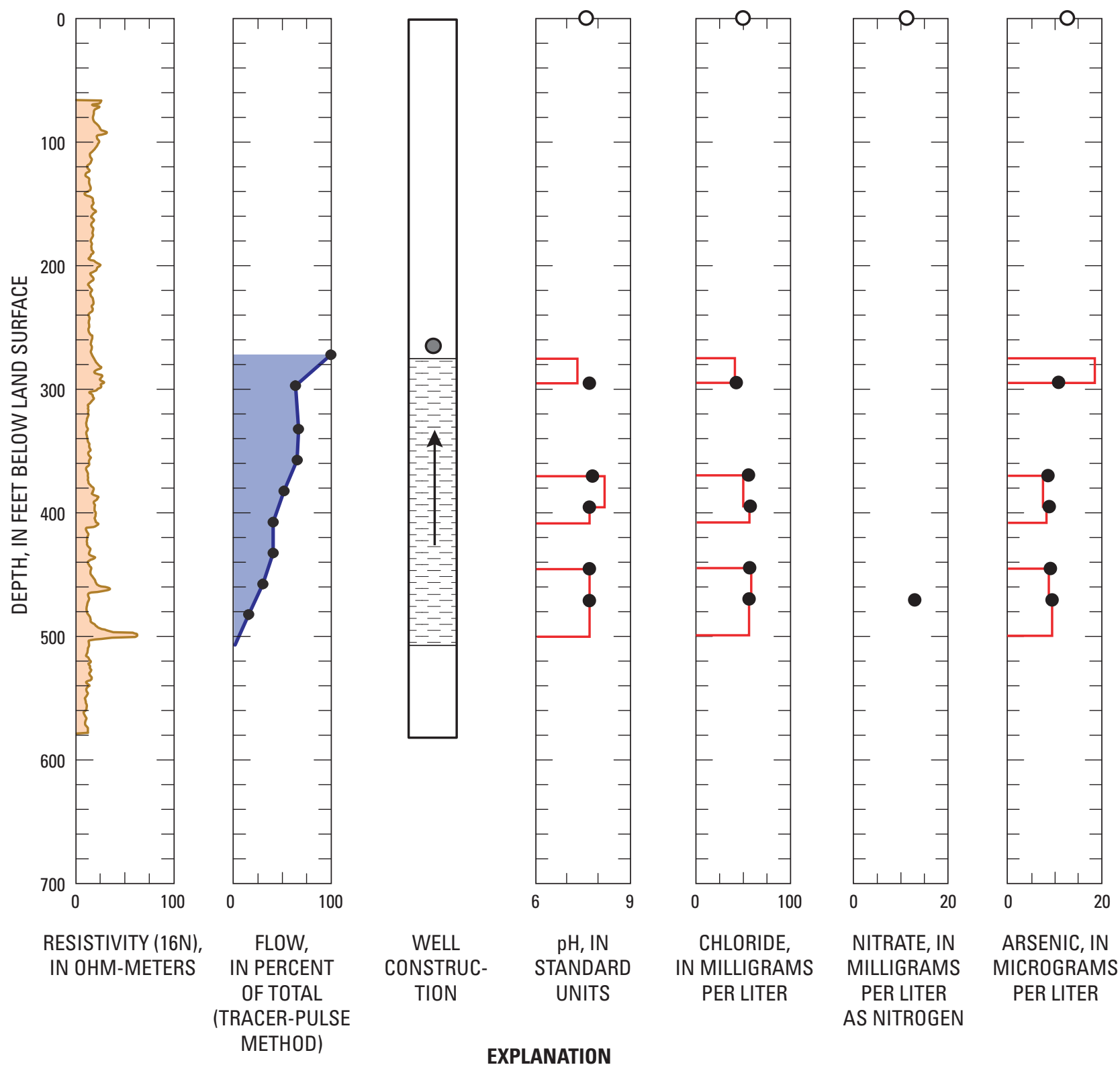
CHLORIDE, IN MILLIGRAMS PER LITER

NITRATE, IN

ARSENIC, IN MICROGRAMS MILLIGRAMS PER LITER PER LITER EXPLANATION

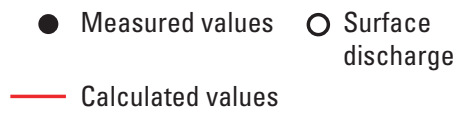

Pump intake

NOTE: Data for pumped and unpumped water levels not available.

Figure 22. Resistivity log, well-bore flow log, well construction, and selected depth-dependent water-quality data from well 001N007E08H002M, Eastern San Joaquin Groundwater Subbasin, California, Febuary 24, 2005. 

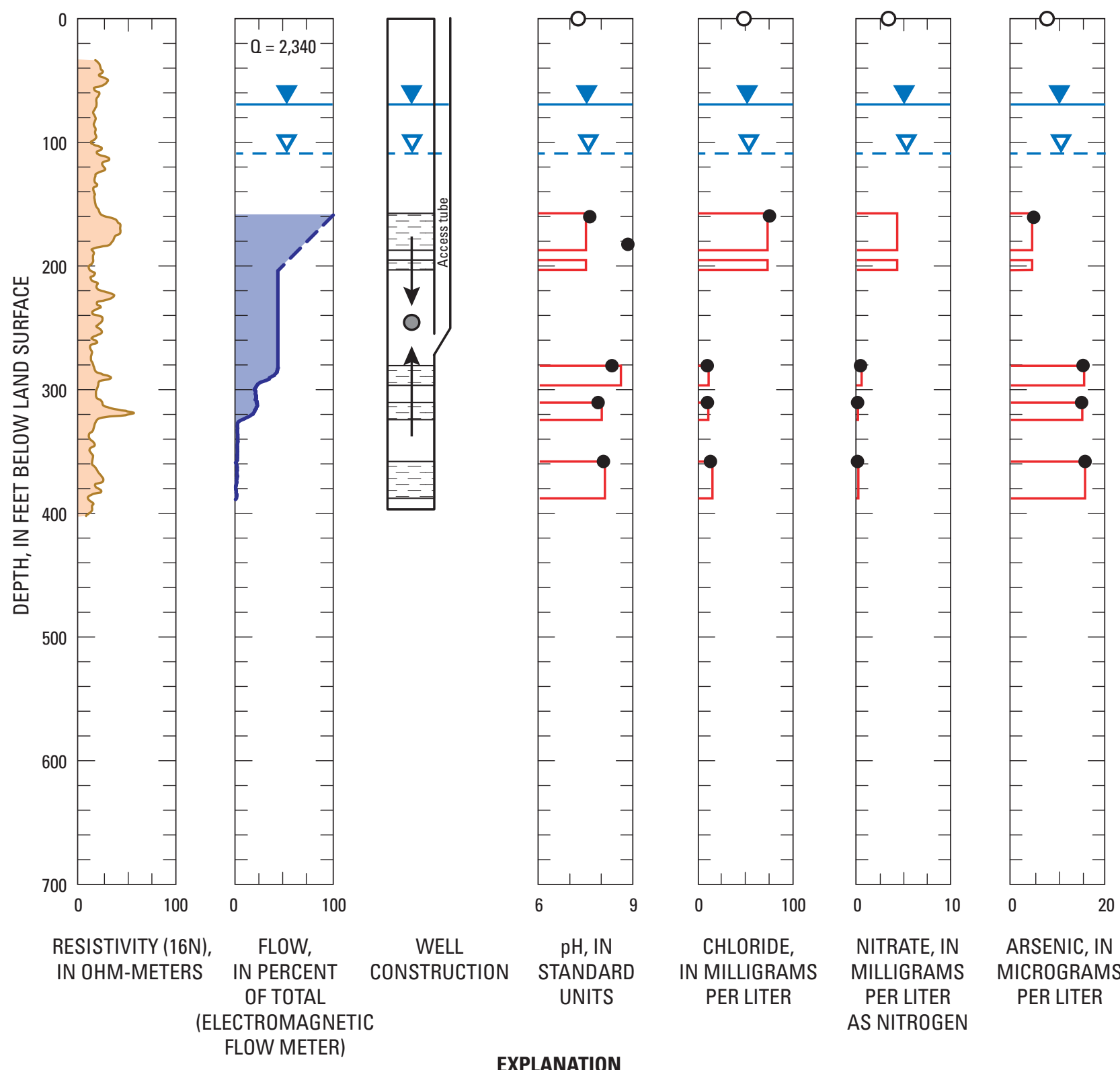
CHLORIDE,
IN MILLIGRAMS
PER LITER

NITRATE, IN

ARSENIC, IN

MILLIGRAMS

PER LITER

MICROGRAMS

AS NITROGEN

PER LITER

\section{EXPLANATION}
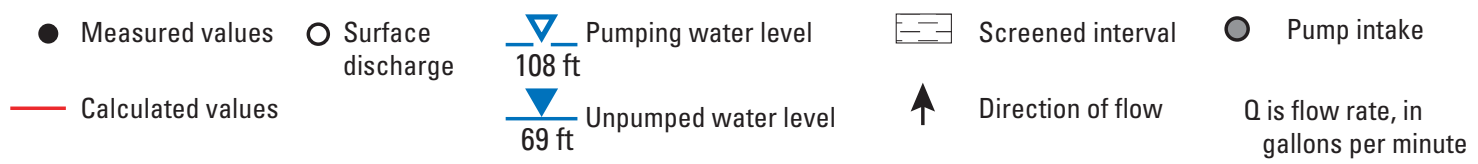

NOTE: Electromagnetic velocity log was normalized for uphole flow; the well-bore flow log was run on July 29, 2004; depth-dependent water-quality data was collected on August 4, 2004.

Figure 23. Resistivity log, well-bore flow log, well construction, and selected depth-dependent water-quality data from well 001N007E20N001M, Eastern San Joaquin Groundwater Subbasin, California, August 2, 2004. 

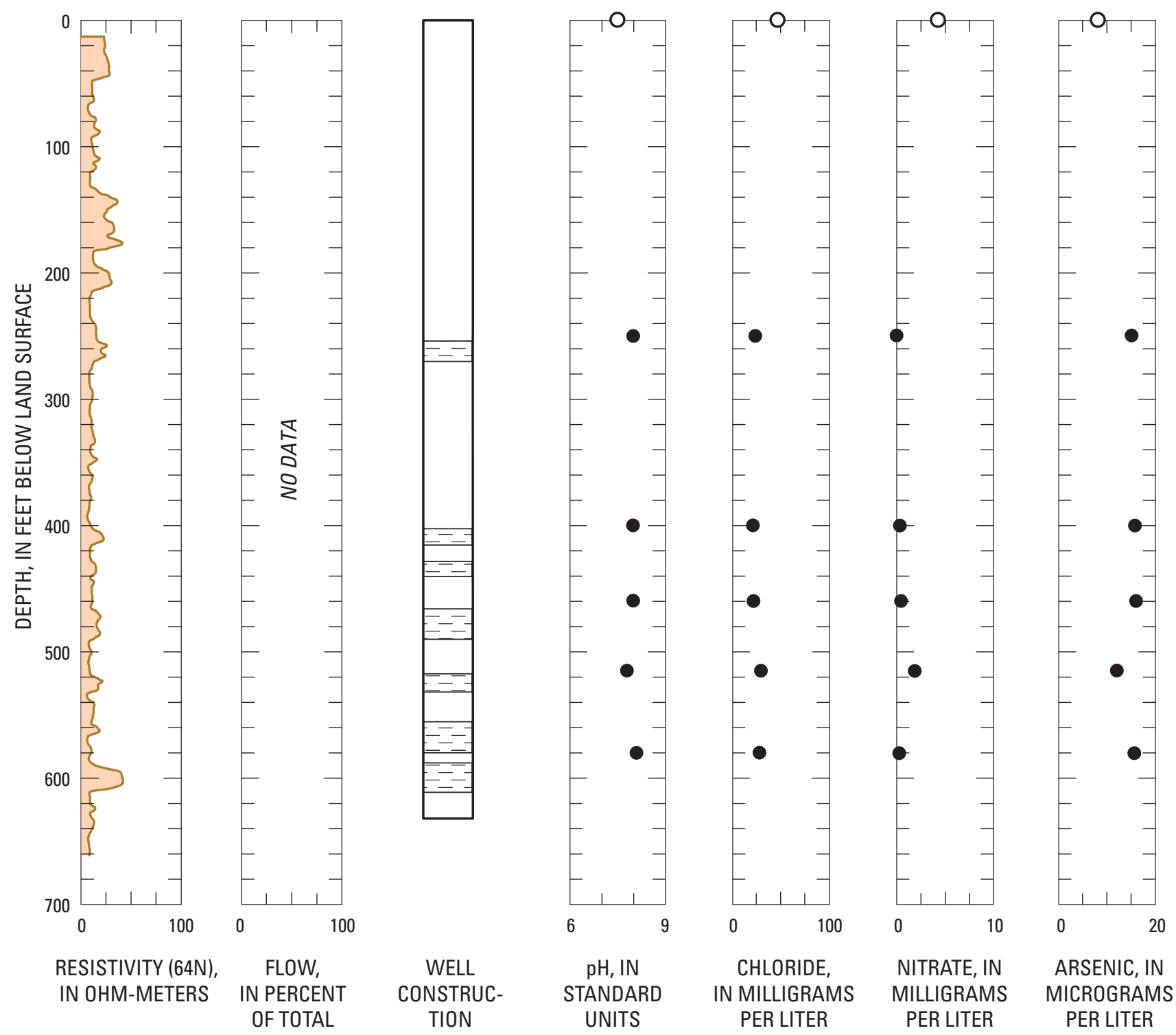

WELL
CONSTRUC

$\mathrm{pH}, \mathrm{IN}$

STANDARD

CHLORIDE,

IN MILLIGRAMS

NITRATE, IN

MILLIGRAMS

ARSENIC, IN

PER LITER

PER LITER

AS NITROGEN

MICROGRAMS

PER LITER

EXPLANATION

Measured values $\begin{aligned} & \text { Surface } \\ & \text { discharge }\end{aligned}$

-- Screened interval

NOTE: Data for pumped and unpumped water levels not available.

Figure 24. Resistivity log, well-bore flow log, well construction, and selected depth-dependent water-quality data from well 001N007E28F001M, Eastern San Joaquin Groundwater Subbasin, California, July 19, 2005. 

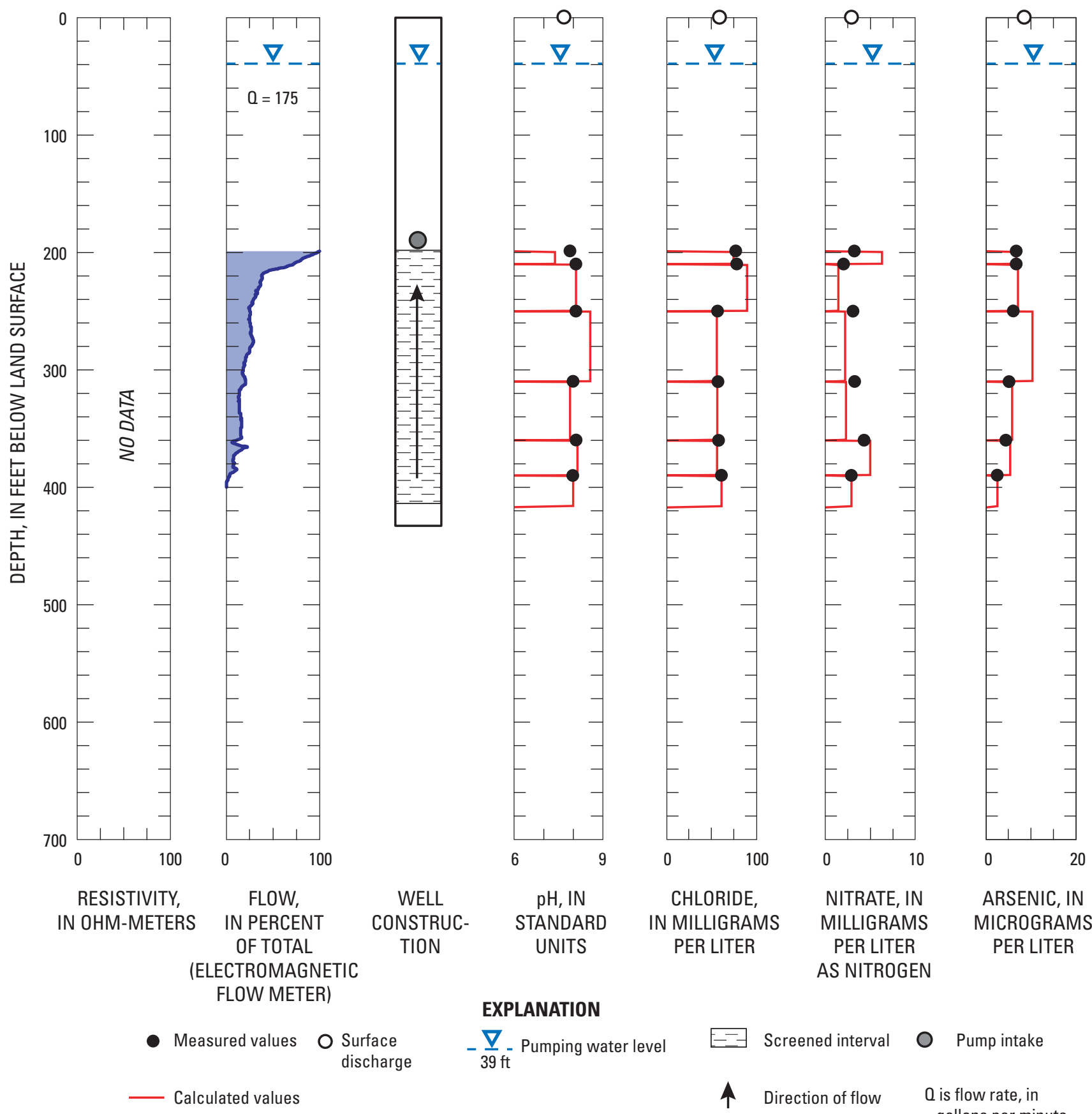

\section{EXPLANATION}

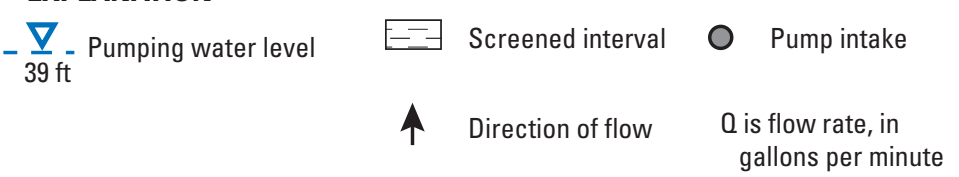

NOTE: Well-bore flow log was run on April 1, 2007; depth-dependent water-quality data was collected on March 26, 2008; unpumped water level not available.

Figure 25. Resistivity log, well-bore flow log, well construction, and selected depth-dependent water-quality data from well 001N007E31C001M, Eastern San Joaquin Ground-Water Subbasin, California, March 26, 2008. 

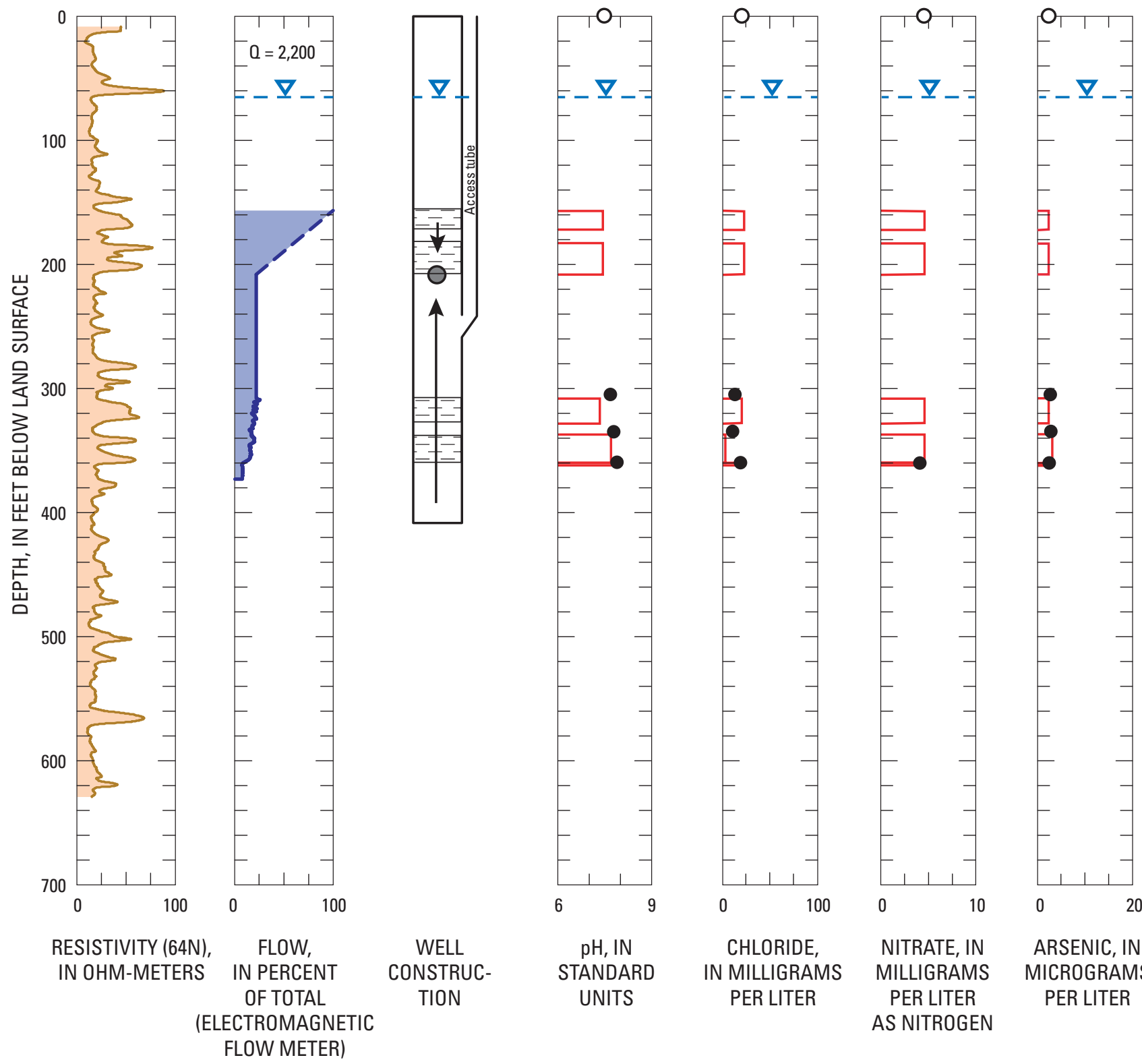
CHLORIDE, IN MILLIGRAMS

NITRATE, IN MILLIGRAMS

ARSENIC, IN MICROGRAMS PER LITER

EXPLANATION
- Measured values $\begin{aligned} & \text { Surface } \\ & \text { discharge }\end{aligned}-\frac{\nabla}{65} \mathrm{ft}$ Pumping water level
E- Screened interval
Calculated values
O Pump intake
个 Direction of flow

0 is flow rate, in gallons per minute

NOTE: Electromagnetic flow meter was normalized for uphole flow; well-bore flow log was run on May 31, 2006; depth-dependent water-quality data was collected on August 9, 2006; unpumped water level not available.

Figure 26. Resistivity log, well-bore flow log, well construction, and selected depth-dependent water-quality data from well 002N006E010001M, Eastern San Joaquin Groundwater Subbasin, California, August 9, 2006. 

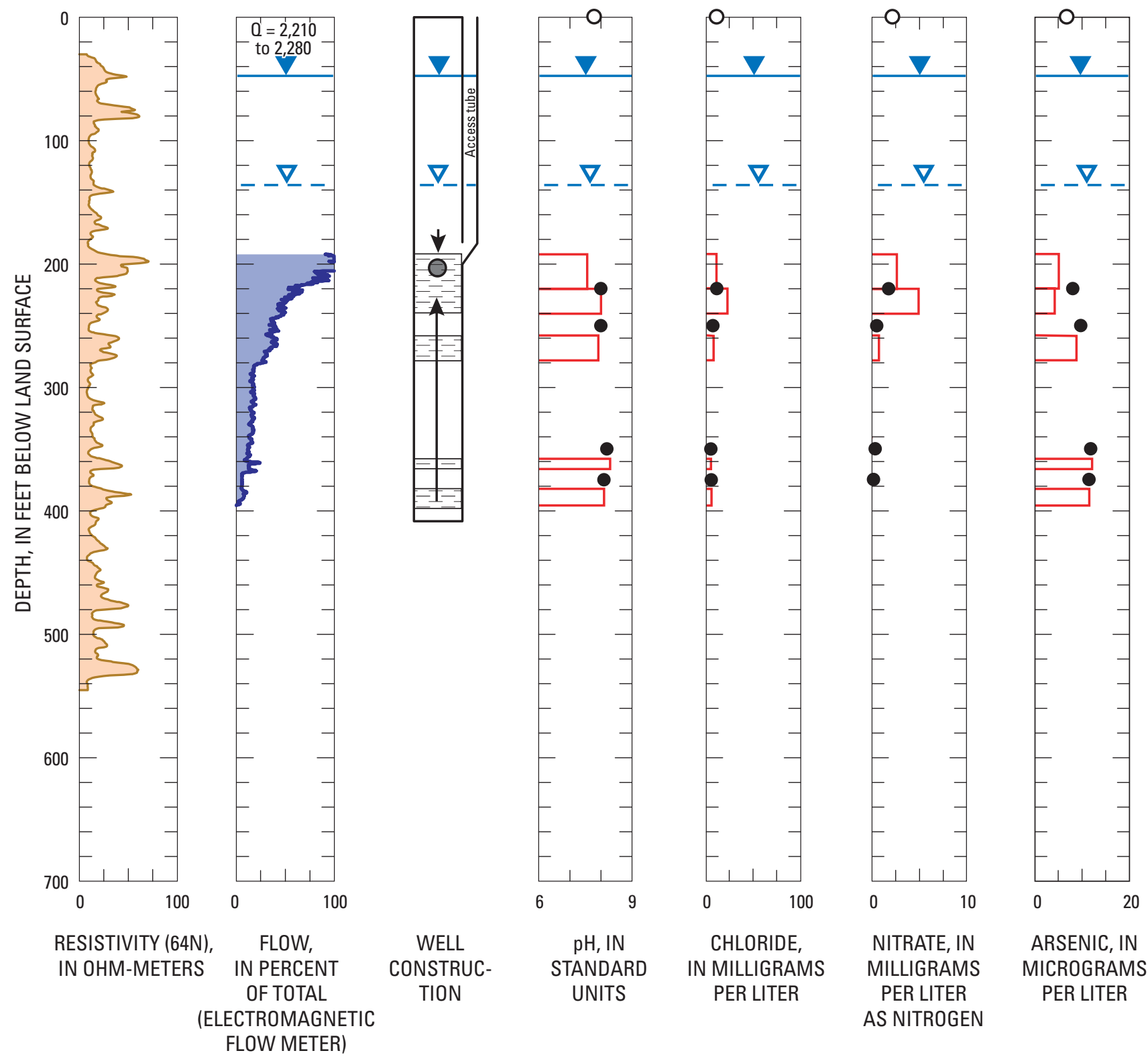
CHLORIDE, IN MILLIGRAMS

NITRATE, IN MILLIGRAMS PER LITER AS NITROGEN

ARSENIC, IN MICROGRAMS PER LITER

\section{EXPLANATION}

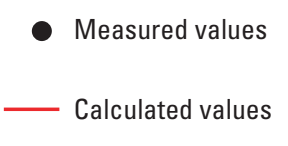

$$
\begin{array}{ll}
\begin{array}{ll}
\text { O Surface } \\
\text { discharge }
\end{array} & -\frac{\nabla}{136 \mathrm{ft}} \text {. Pumping water level } \\
& \frac{\nabla}{47 \mathrm{ft}} \text { Unpumped water level }
\end{array}
$$

$E$ Screened interval

个 Direction of flow
Pump intake

0 is flow rate, in gallons per minute

NOTE: Electromagnetic flow meter was normalized for uphole flow; well-bore flow log was run on July 7, 2005; depth-dependent water-quality data was collected on July 13-14, 2005.

Figure 27. Resistivity log, well-bore flow log, well construction, and selected depth-dependent water-quality data from well 002N006E040001M, Eastern San Joaquin Groundwater Subbasin, California, July 13-14, 2005. 

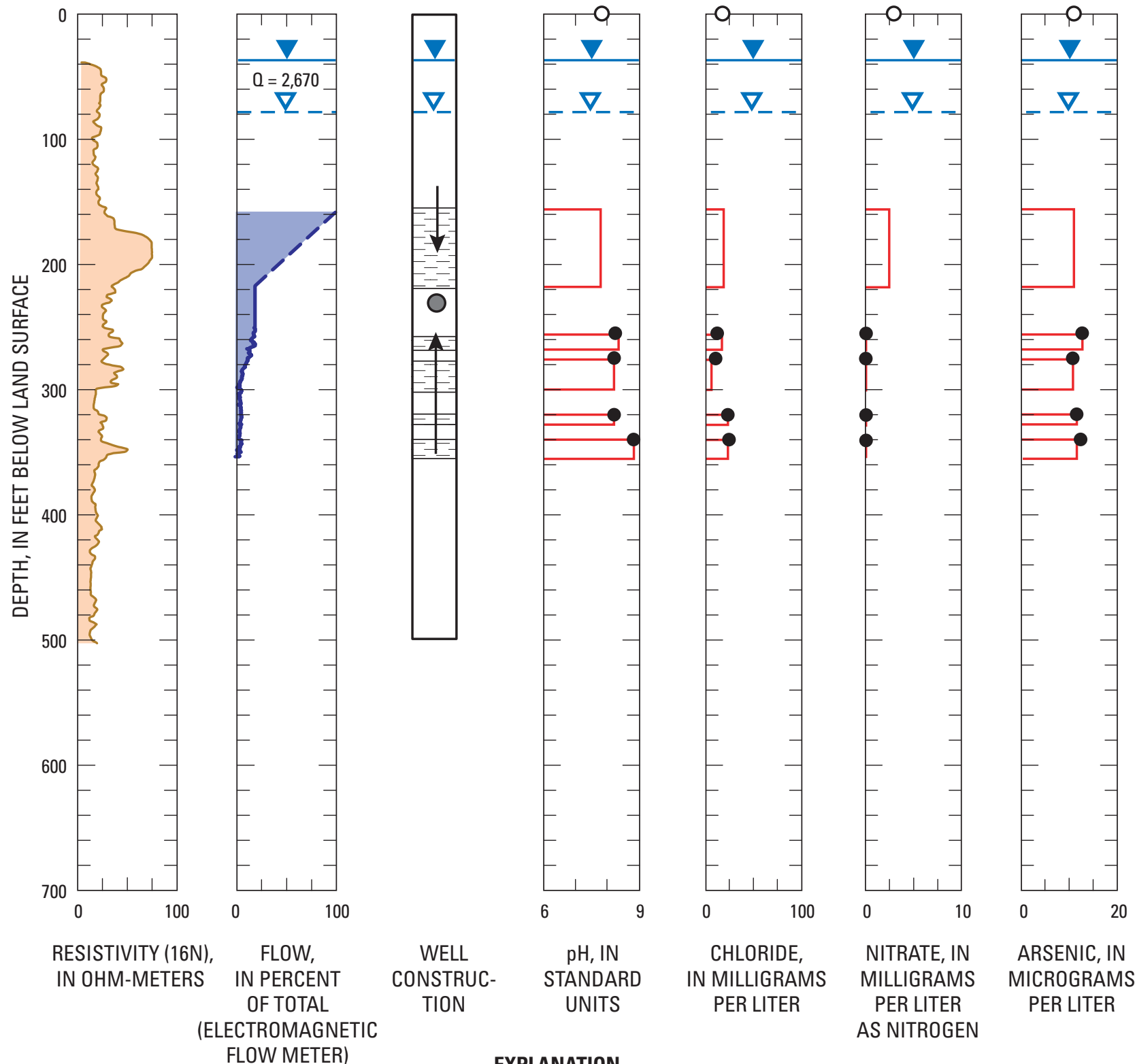

WELL CONSTRUC- STANDARD

CHLORIDE, NITRATE, IN

ARSENIC, IN IN MILLIGRAMS

PER LITER MILLIGRAMS PER LITER MICROGRAMS AS NITROGEN PER LITER EXPLANATION
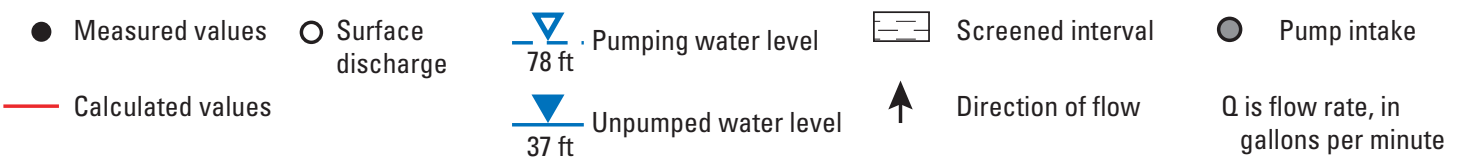

NOTE: Electromagnetic velocity log was normalized for uphole flow; well-bore flow log was run on July 27, 2004; depth-dependent water-quality data was collected on August 3, 2004

Figure 28. Resistivity log, well-bore flow log, well construction, and selected depth-dependent water-quality data from well 002N006E05F001M, Eastern San Joaquin Groundwater Subbasin, California, August 3, 2004. 

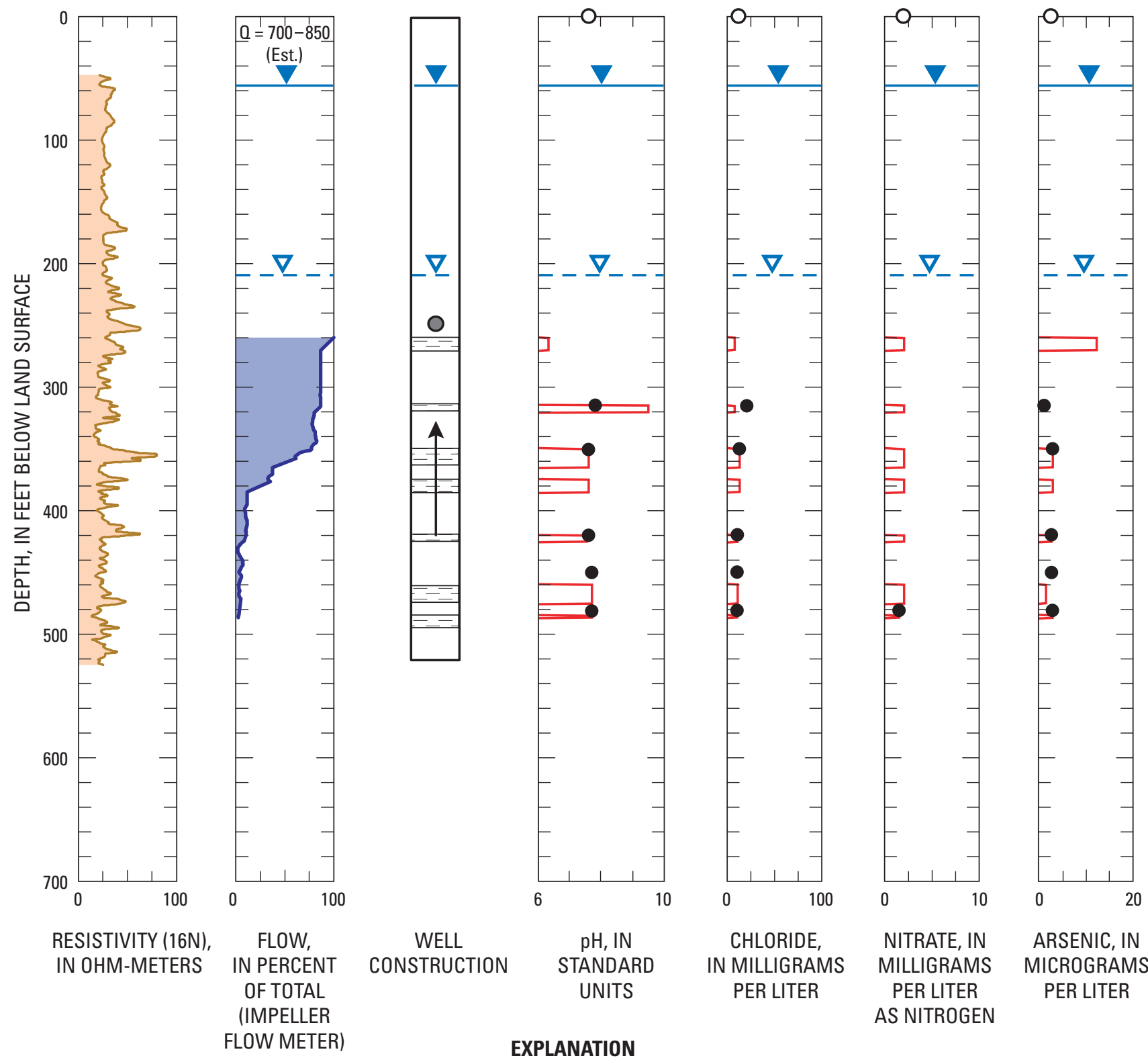
CHLORIDE, IN MILLIGRAMS
PER LITER
NITRATE, IN MILLIGRAMS
PER LITER

ARSENIC, IN MICROGRAMS

PER LITER

\section{EXPLANATION}
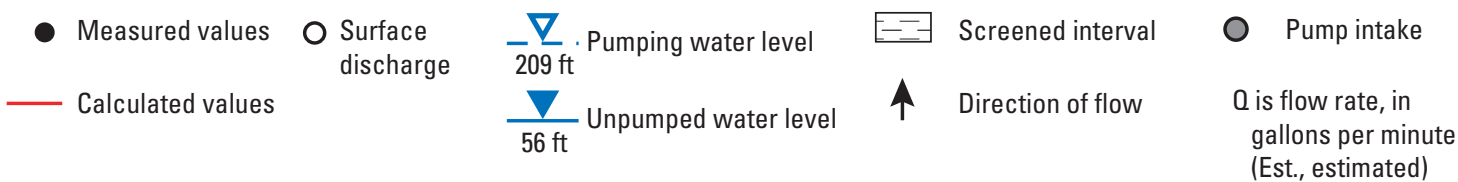

NOTE: Well-bore flow log was run on July 16, 2007; depth-dependent water-quality data was collected on June 20, 2007.

Figure 29. Resistivity log, well-bore flow log, well construction, and selected depth-dependent water-quality data from well 002N006E11H003M, Eastern San Joaquin Groundwater Subbasin, California, June 20, 2007. 

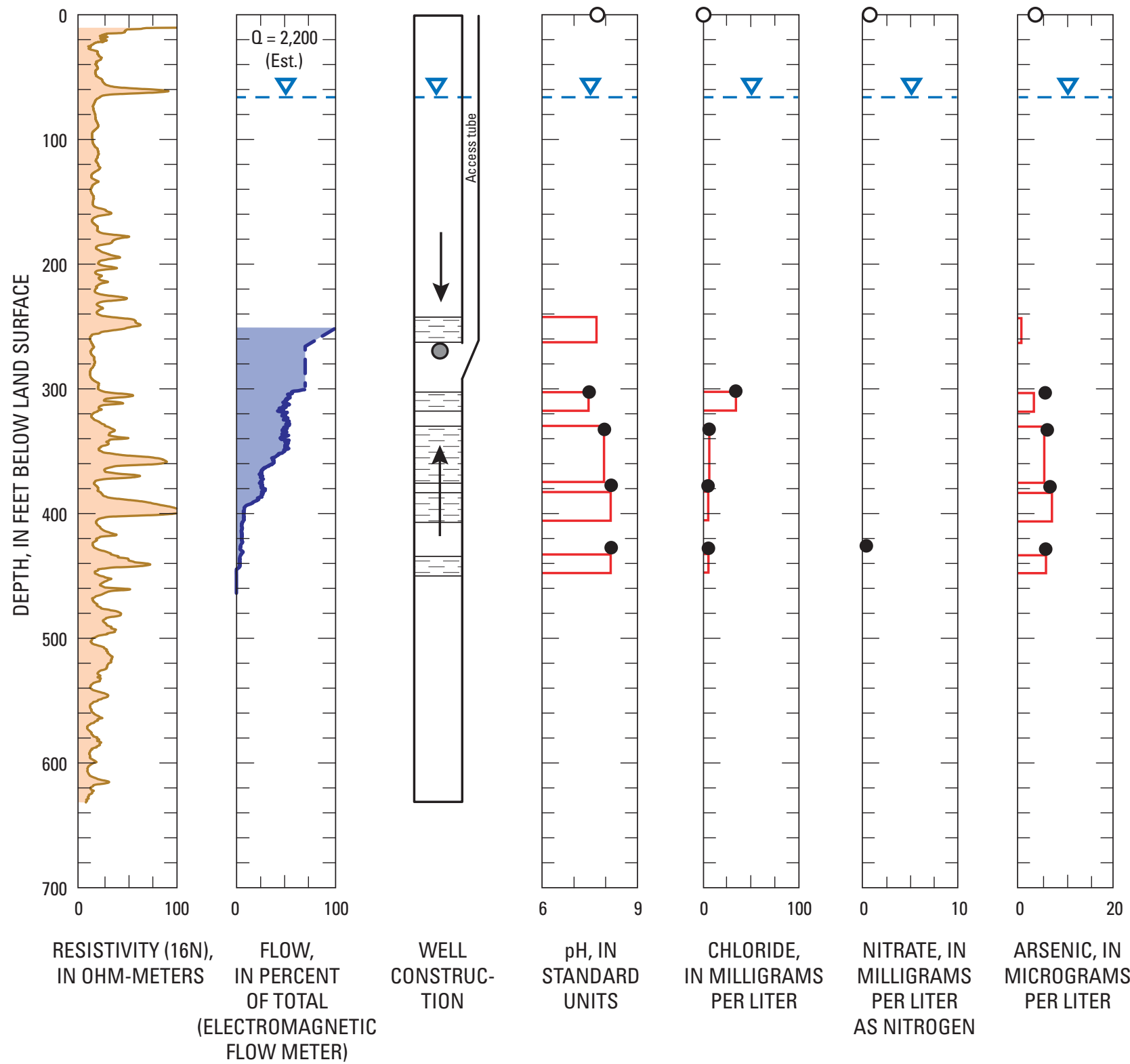

NITRATE, IN

ARSENIC, IN MILLIGRAMS MICROGRAMS

PER LITER PER LITER

\section{EXPLANATION}

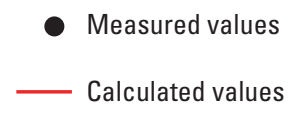
O Surface discharge

$\frac{\nabla}{66.3 \mathrm{ft}}$ Pumping water level

O Pump intake

NOTE: Electromagnetic velocity log was normalized for uphole flow; well-bore flow log was run on July 14, 2006; depth-dependent water-quality data was collected on August 8, 2006.

Figure 30. Resistivity log, well-bore flow log, well construction, and selected depth-dependent water-quality data from well 002N006E12J001M, Eastern San Joaquin Groundwater Subbasin, California, August 8, 2006. 

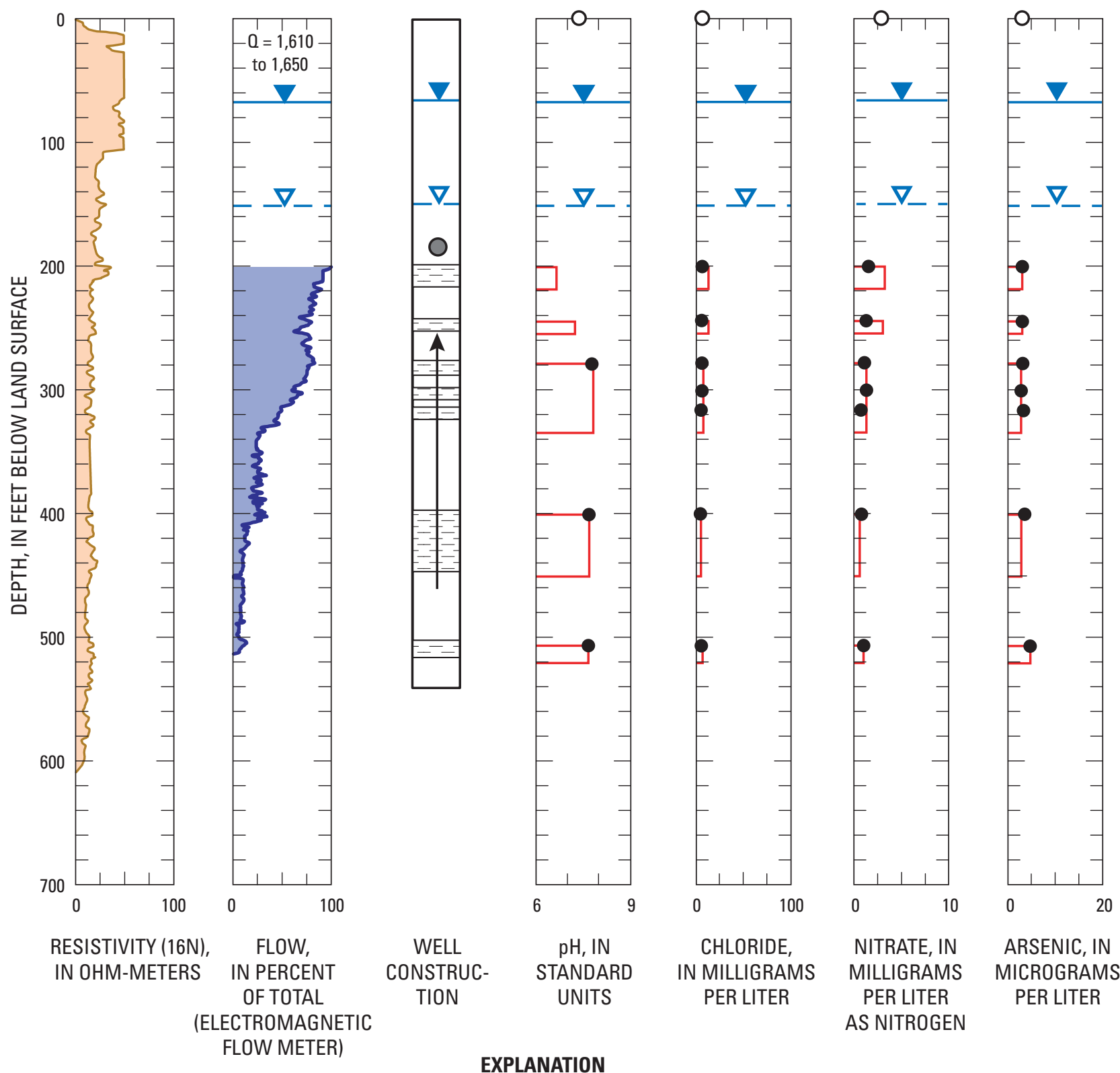

ARSENIC, IN

MICROGRAMS

PER LITER

\section{EXPLANATION}

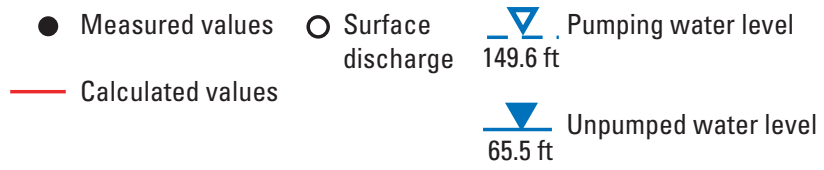

$\begin{array}{lll}\text {-二 Screened interval } & 0 \text { Pump intake } \\ \text { Direction of flow } & \begin{array}{r}0 \text { is flow rate, in } \\ \text { gallons per minute }\end{array}\end{array}$

NOTE: Well-bore flow log was run on July 28, 2004; depth-dependent water-quality data was collected on August 5, 2004.

Figure 31. Resistivity log, well-bore flow log, well construction, and selected depth-dependent water-quality data from well 002N006E24P004M, Eastern San Joaquin Groundwater Subbasin, California, August 5, 2004. 

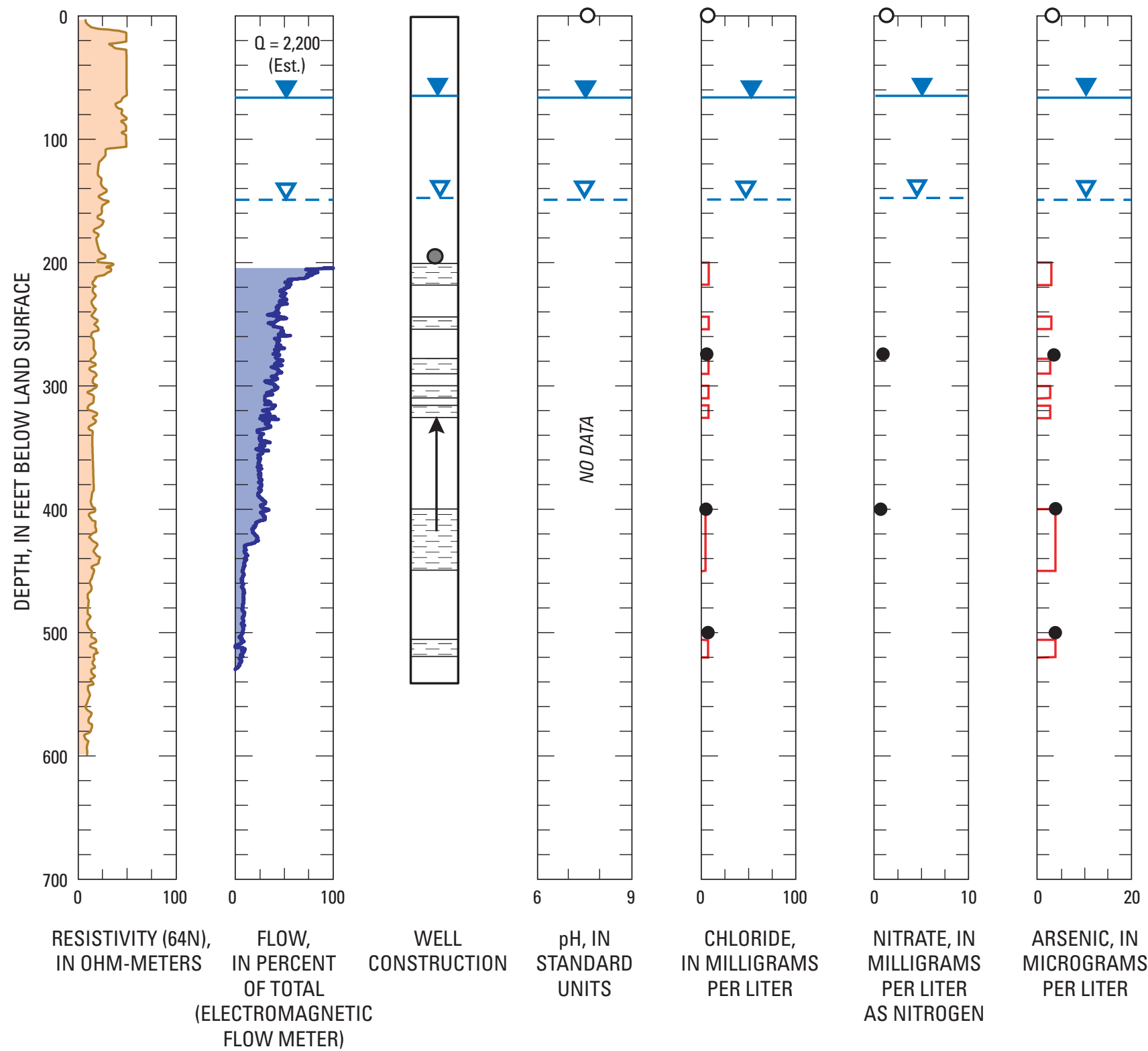
CHLORIDE, IN MILLIGRAMS PER LITER

NITRATE, IN MILLIGRAMS PER LITER ARSENIC, IN MICROGRAMS AS NITROGEN

PER LITER

EXPLANATION
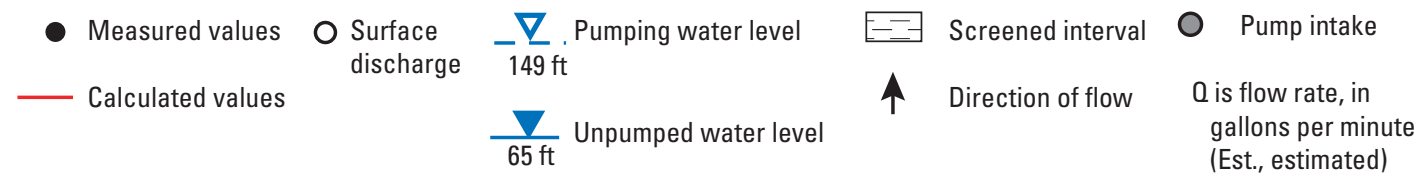

NOTE: Well-bore flow log was run on February 15, 2005; depth-dependent water-quality data was collected on January 26-28, 2006.

Figure 32. Resistivity log, well-bore flow log, well construction, and selected depth-dependent water-quality data from well 002N006E24P004M, Eastern San Joaquin Groundwater Subbasin, California, January 26-28, 2006. 

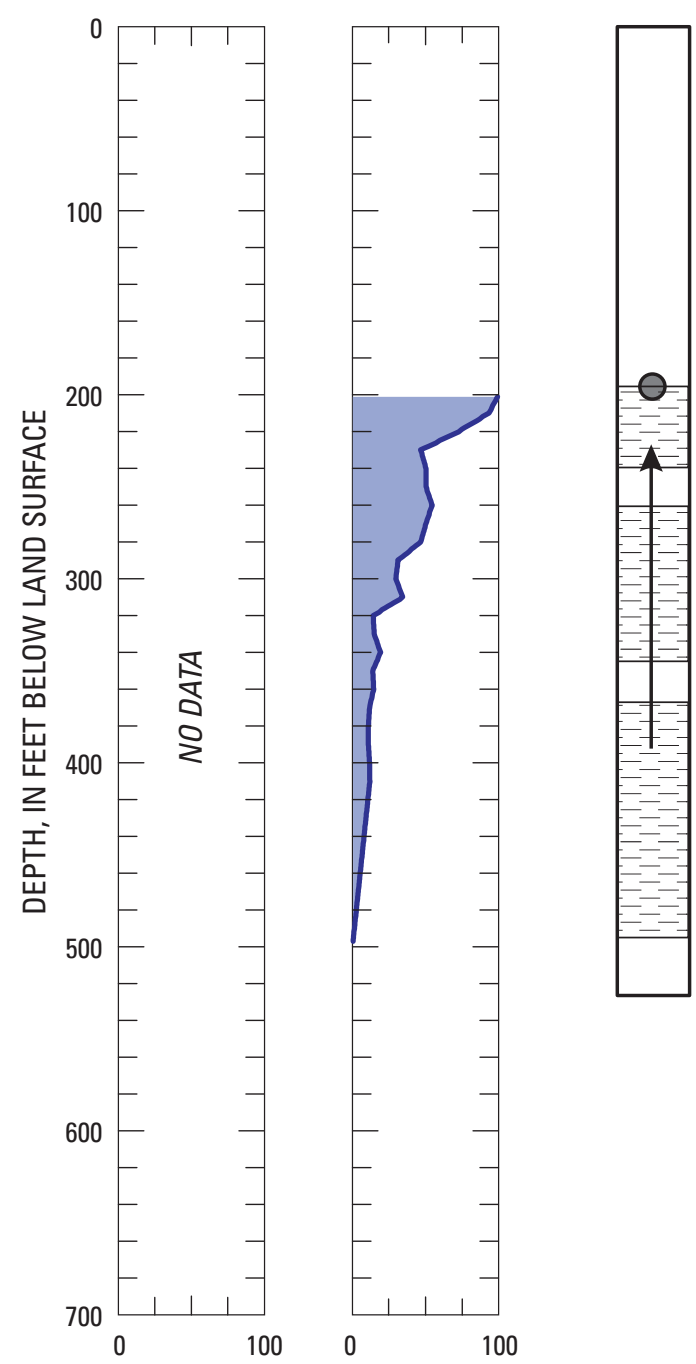

$$
\text { RESISTIVITY, }
$$
IN OHM-METERS

100

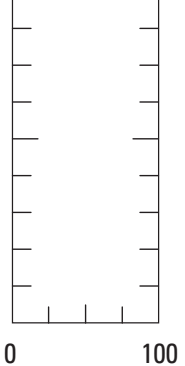

FLOW,
IN PERCENT OF TOTAL

(TRACER-PULSE METHOD)

- Measured values
Calculated values

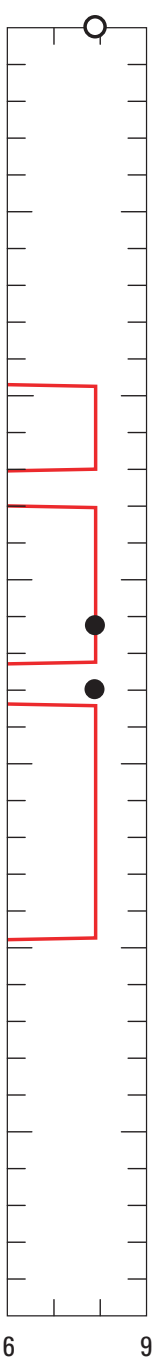

WELL

CONSTRUCTION

$$
\begin{aligned}
& \text { Surface } \\
& \text { discharge }
\end{aligned}
$$

$\mathrm{pH}, \mathrm{IN}$

STANDARD

UNITS

\section{EXPLANATION} e

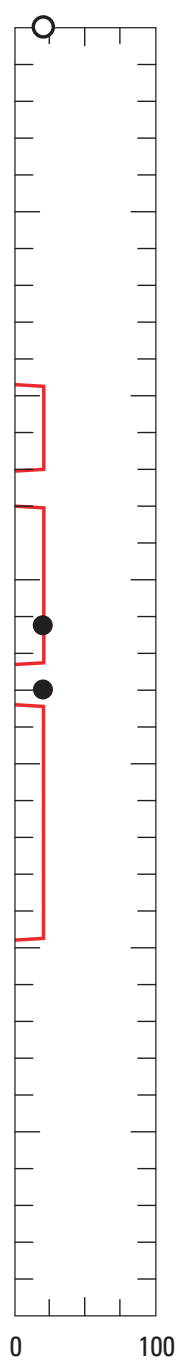

CHLORIDE, IN MILLIGRAMS PER LITER

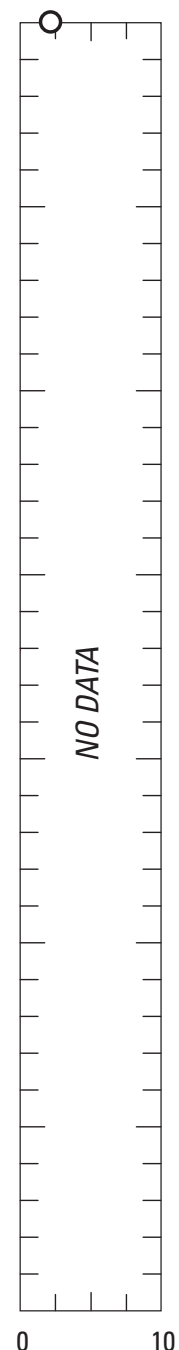

NITRATE, IN

MILLIGRAMS

PER LITER AS NITROGEN

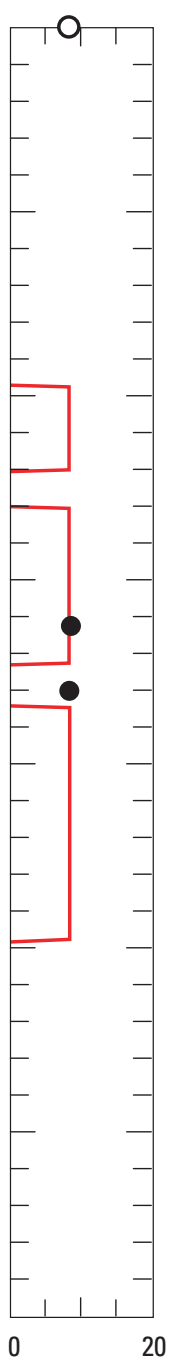

ARSENIC, IN MICROGRAMS PER LITER 


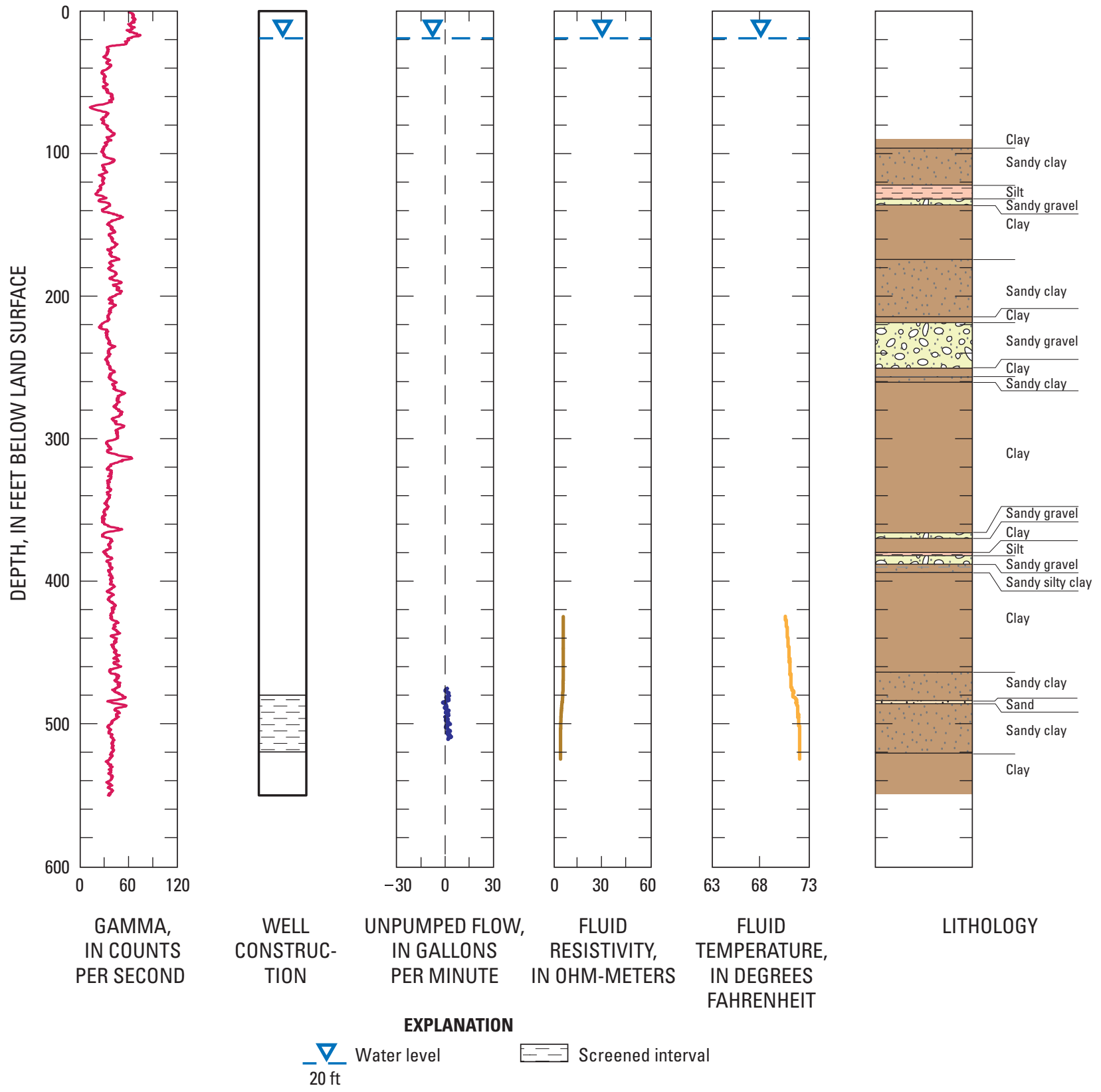

Figure 34. Gamma log, well construction, unpumped well-bore flow, fluid resistivity, fluid temperature, and lithology data from well 001N006E04P002M, Eastern San Joaquin Groundwater Subbasin, California, February 24, 2005. 

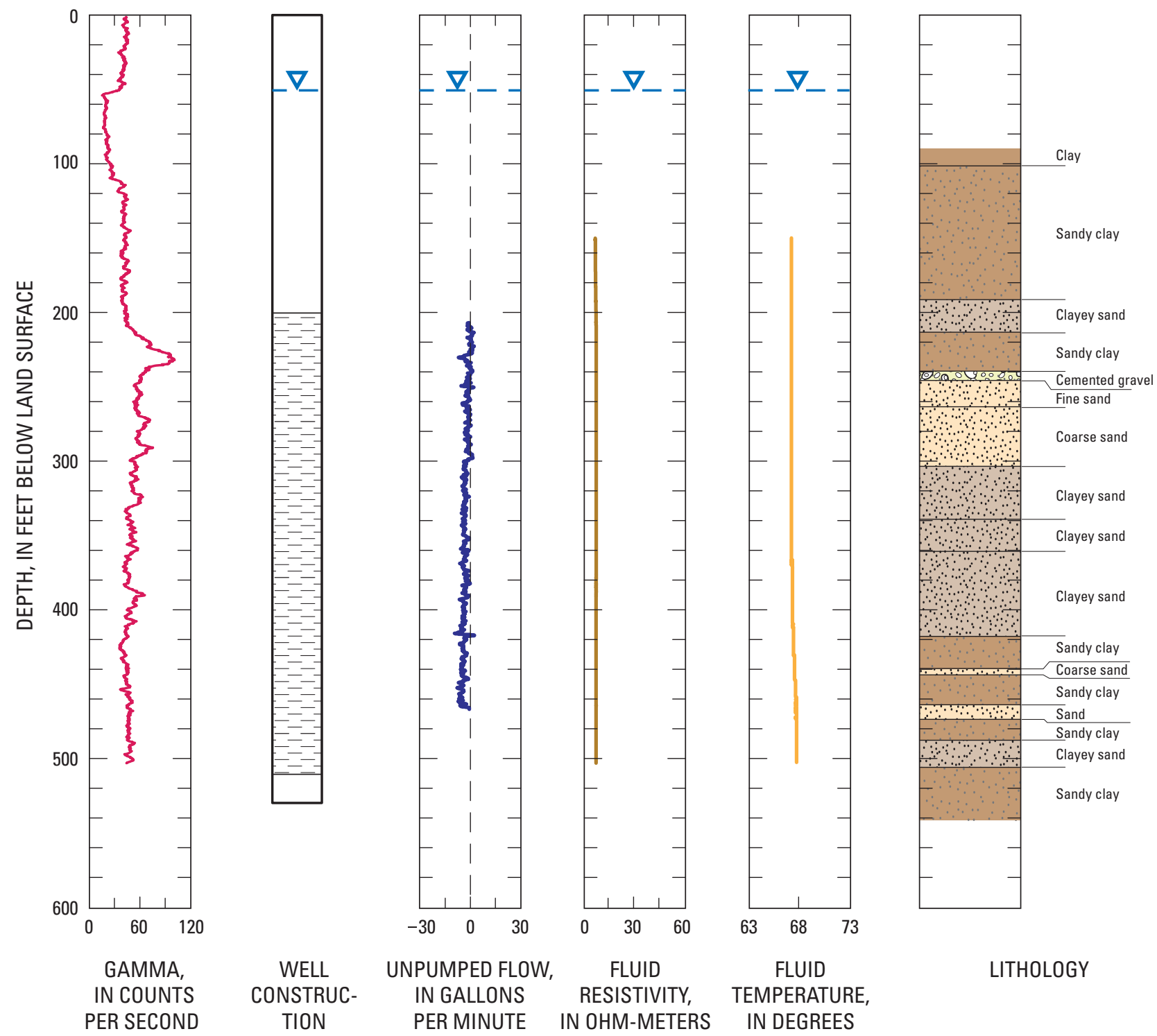
WELL CONSTRUC-
TION

UNPUMPED FLOW, IN GALLONS

PER MINUTE

FLUID

FLUID

LITHOLOGY

RESISTIVITY,

TEMPERATURE,

IN DEGREES

FAHRENHEIT

EXPLANATION

$$
-\frac{\nabla}{51 \mathrm{ft}} \text { Water level } \quad[--] \text { Screened interval }
$$

Figure 35. Gamma log, well construction, unpumped well-bore flow, fluid resistivity, fluid temperature, and lithology data from well 001N006E012A001M, Eastern San Joaquin Groundwater Subbasin, California, February 23, 2005. 

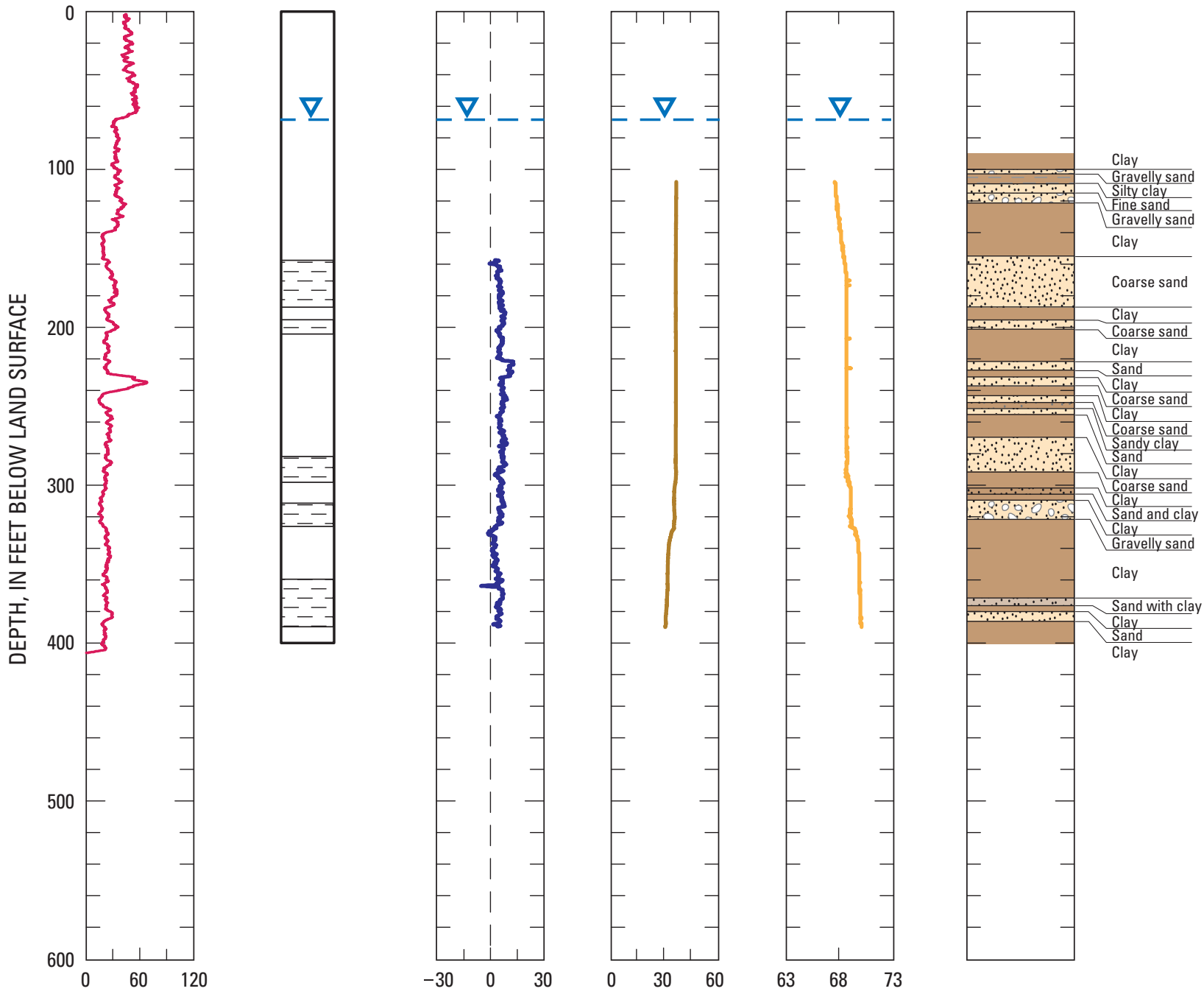
$\begin{array}{cc}\text { GAMMA, } & \text { WELL } \\ \text { IN COUNTS } & \text { CONSTRUC- } \\ \text { PER SECOND } & \text { TION }\end{array}$

UNPUMPED FLOW,

FLUID

FLUID

LITHOLOGY PER MINUTE IN OHM-METERS

TEMPERATURE,

IN DEGREES

FAHRENHEIT

EXPLANATION

$$
-\frac{\nabla}{68 \mathrm{ft}} \text { Water level } \quad[-二 \text { Screened interval }
$$

Figure 36. Gamma log, well construction, unpumped well-bore flow, fluid resistivity, fluid temperature, and lithology data from well 001N007E20N001M, Eastern San Joaquin Groundwater Subbasin, California, July 16, 2005. 


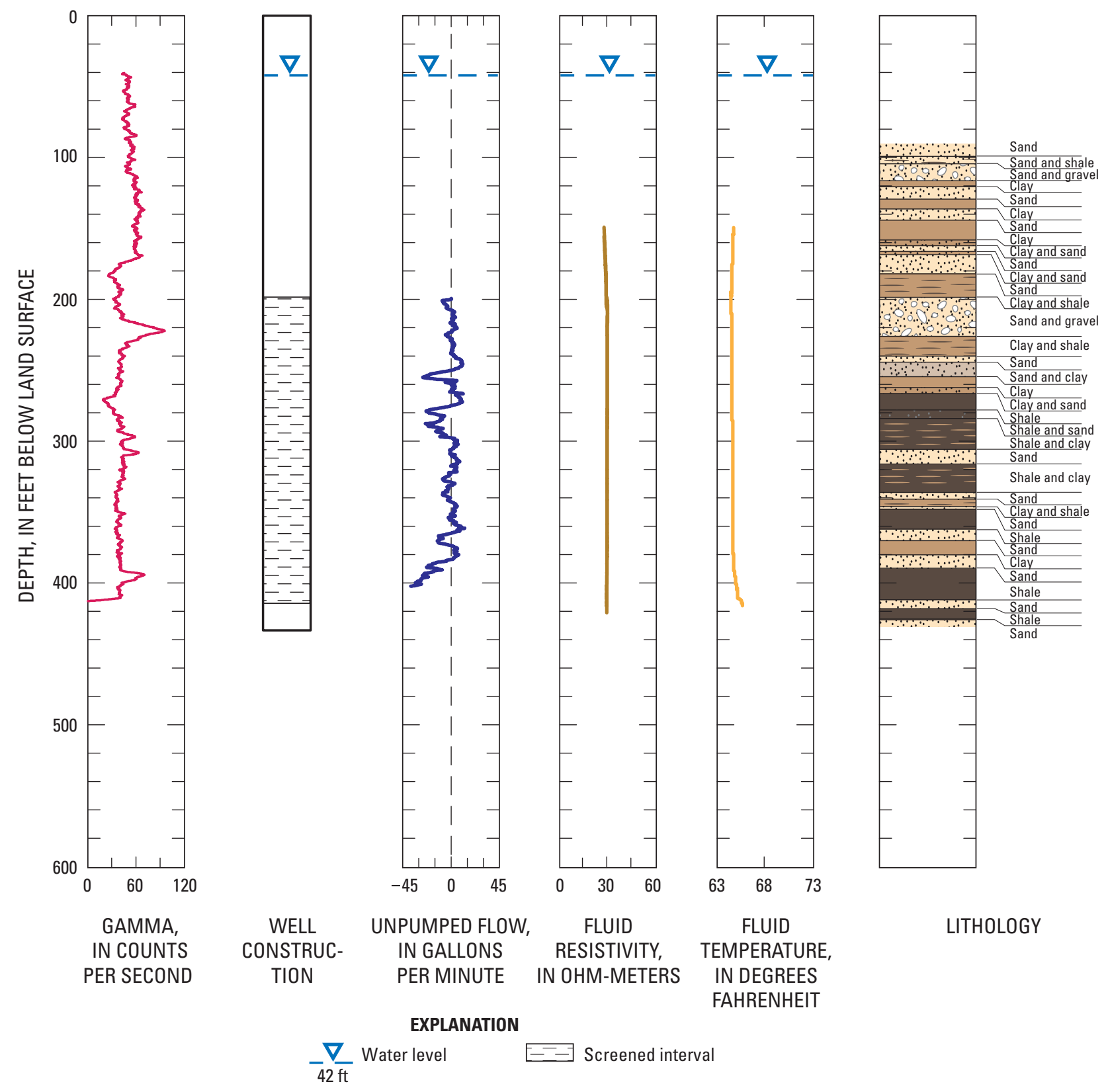

Figure 37. Gamma log, well construction, unpumped well-bore flow, fluid resistivity, fluid temperature, and lithology data from well 001N007E31C001M, Eastern San Joaquin Groundwater Subbasin, California, March 19, 2007. 


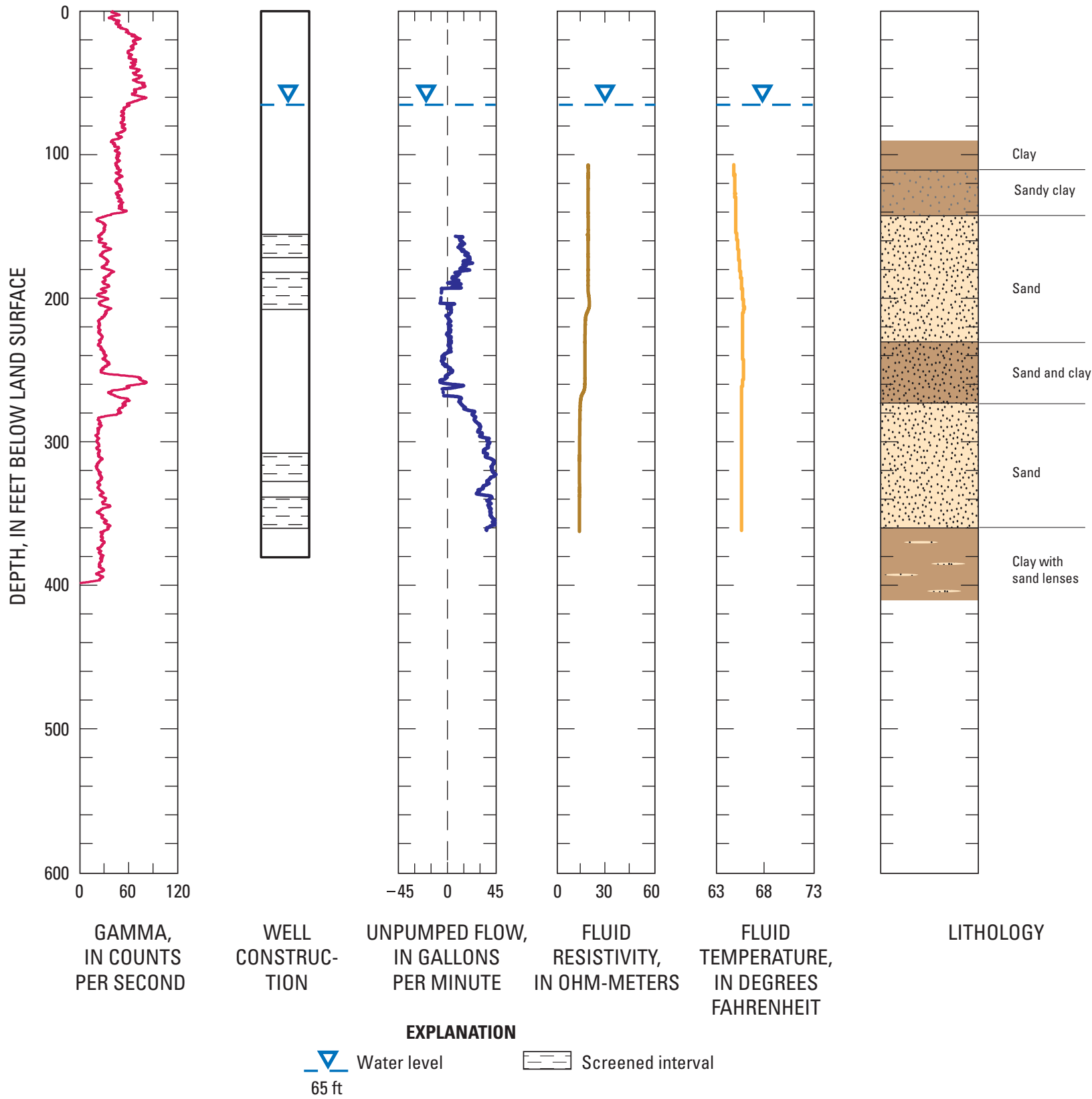

Figure 38. Gamma log, well construction, unpumped well-bore flow, fluid resistivity, fluid temperature, and lithology data from well 002N006E010001M, Eastern San Joaquin Groundwater Subbasin, California, January 18, 2006. 


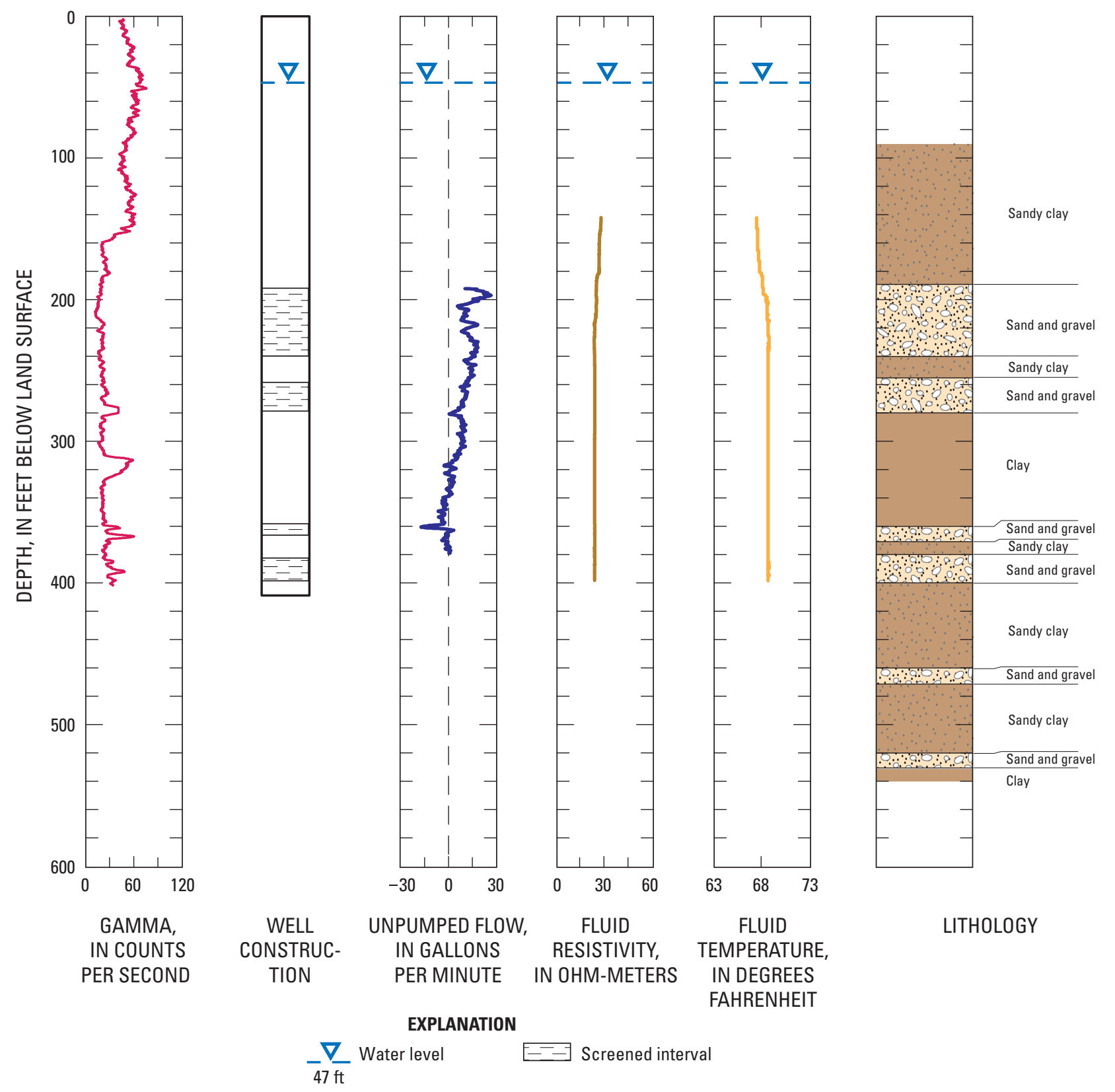

Figure 39. Gamma log, well construction, unpumped well-bore flow, fluid resistivity, fluid temperature, and lithology data from well 002N006E040001M, Eastern San Joaquin Groundwater Subbasin, California, June 8, 2005. 


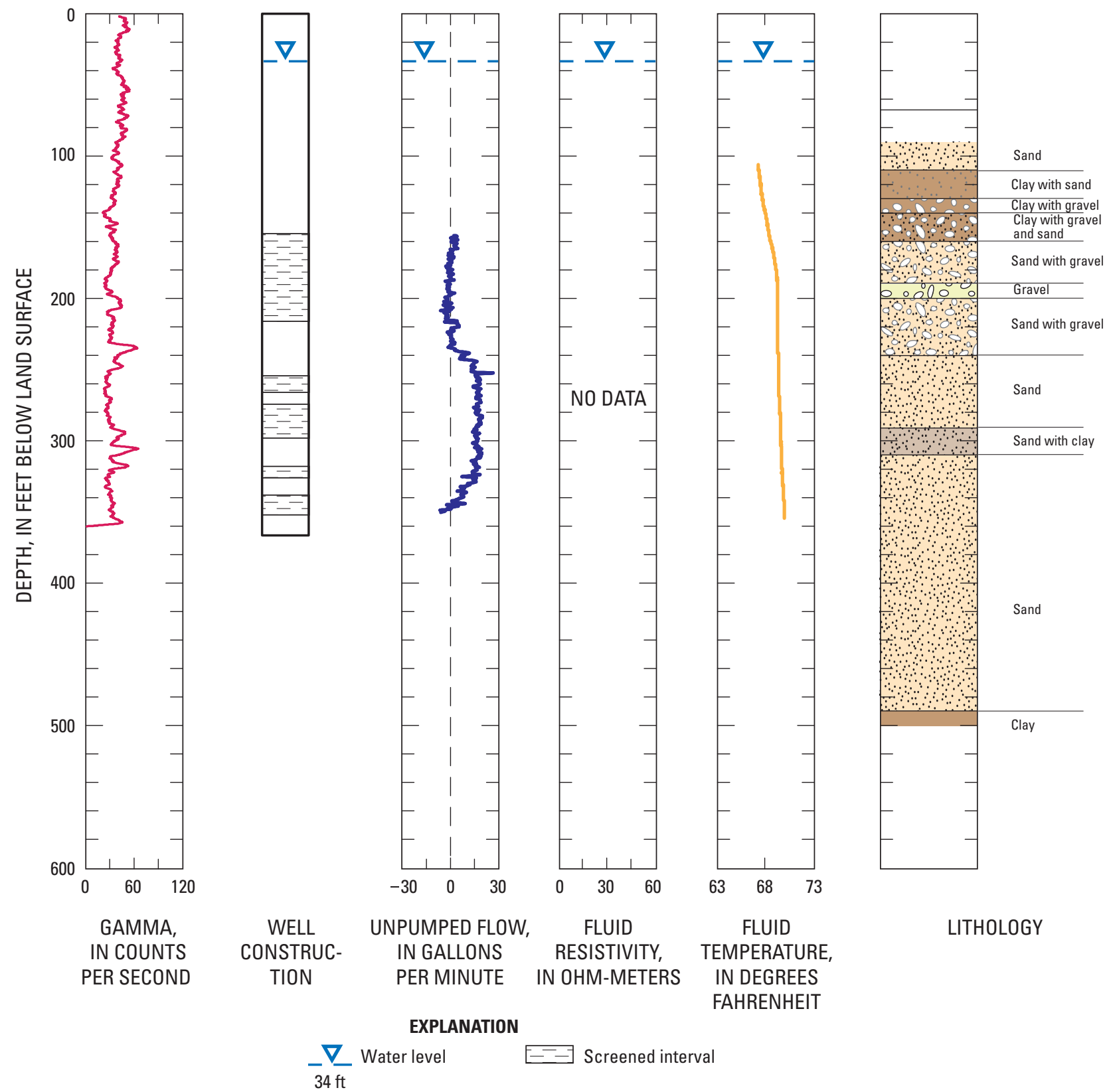

Figure 40. Gamma log, well construction, unpumped well-bore flow, fluid resistivity, fluid temperature, and lithology data from well 002N006E05F001M, Eastern San Joaquin Groundwater Subbasin, California, February 17, 2005. 

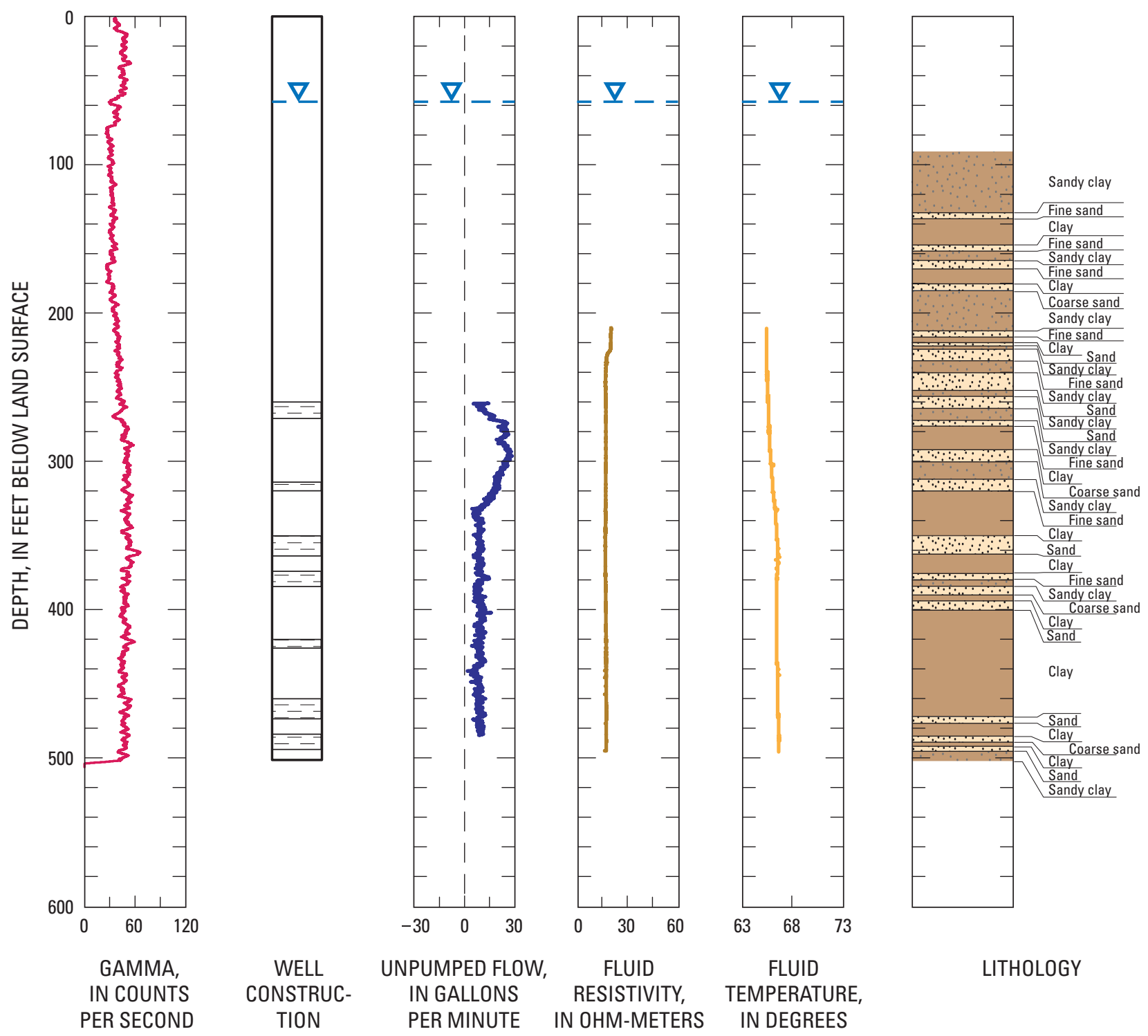

WELL CONSTRUC-

UNPUMPED FLOW, IN GALLONS

FLUID

FLUID

LITHOLOGY PER SECOND TION PER MINUTE RESISTIVITY, TEMPERATURE, IN DEGREES FAHRENHEIT EXPLANATION $-\frac{\nabla}{58 \mathrm{ft}}$ Water level $\quad$ - - Screened interval

Figure 41. Gamma log, well construction, unpumped well-bore flow, fluid resistivity, fluid temperature, and lithology data from well 002N006E11H003M, Eastern San Joaquin Groundwater Subbasin, California, March $27,2007$. 


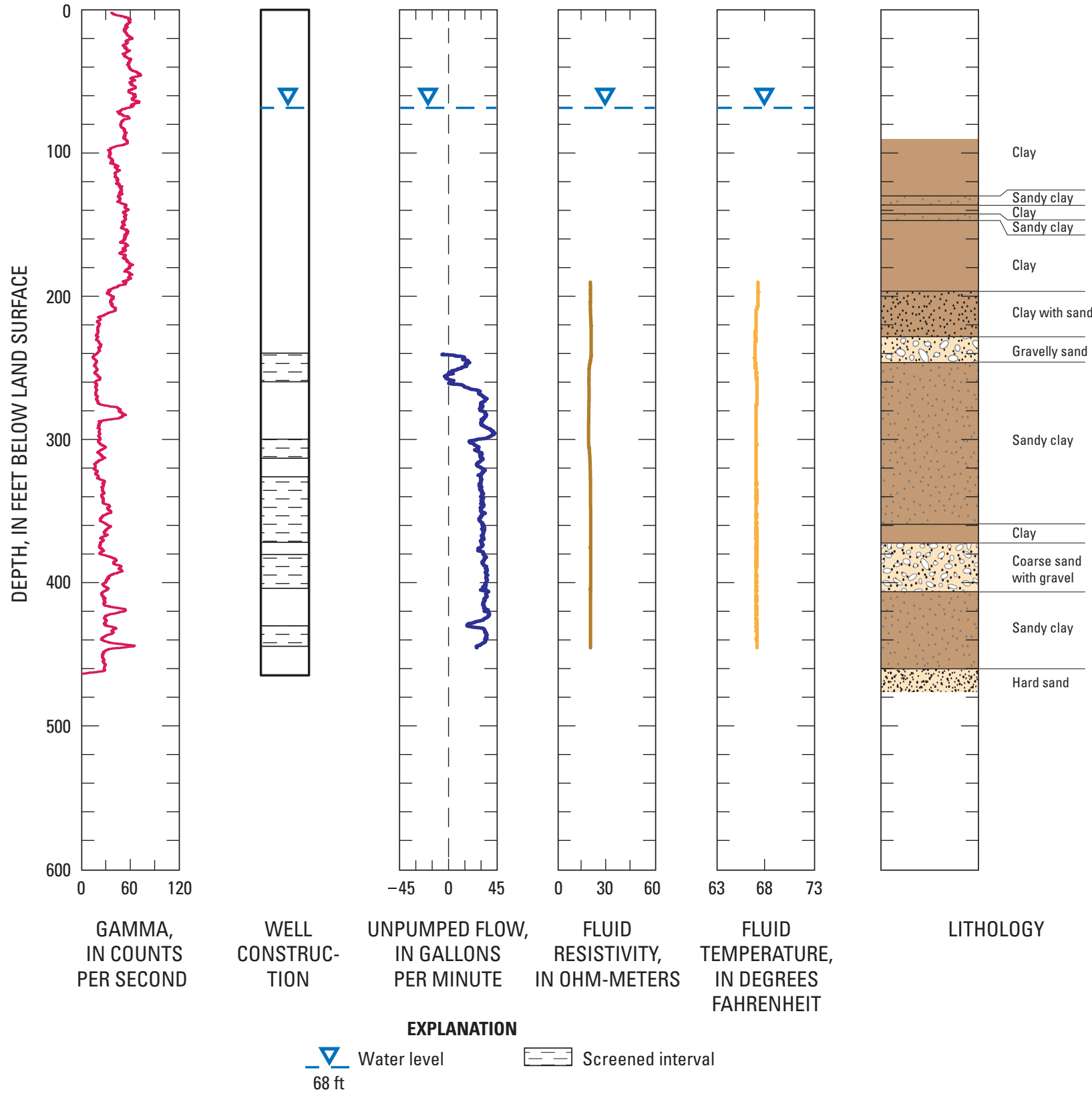

Figure 42. Gamma log, well construction, unpumped well-bore flow, fluid resistivity, fluid temperature, and lithology data from well 002N006E12J001M, Eastern San Joaquin Groundwater Subbasin, California, May 25, 2006. 


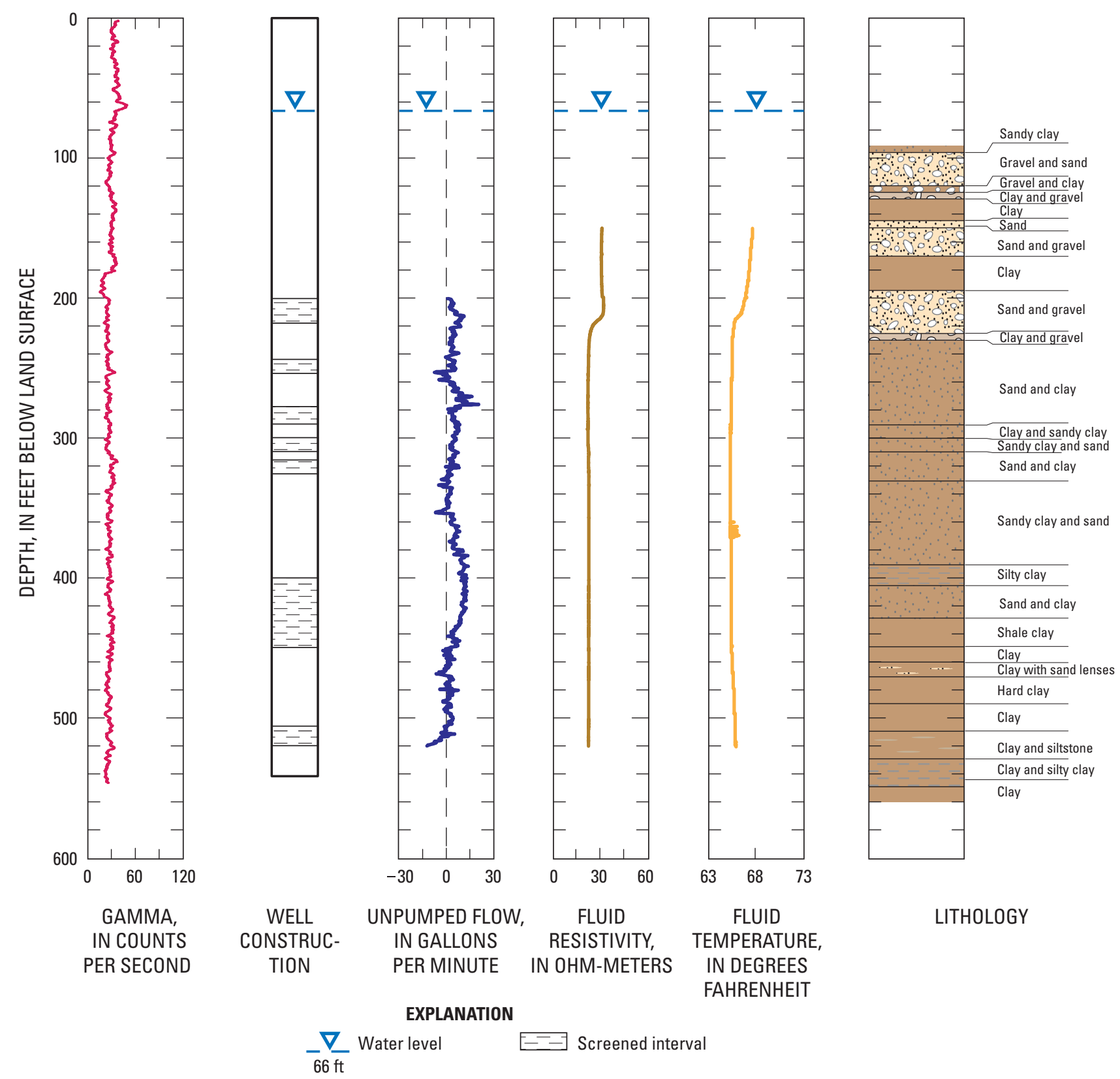

Figure 43. Gamma log, well construction, unpumped well-bore flow, fluid resistivity, fluid temperature, and lithology data from well 002N006E24P004M, Eastern San Joaquin Groundwater Subbasin, California, February 15, 2005. 


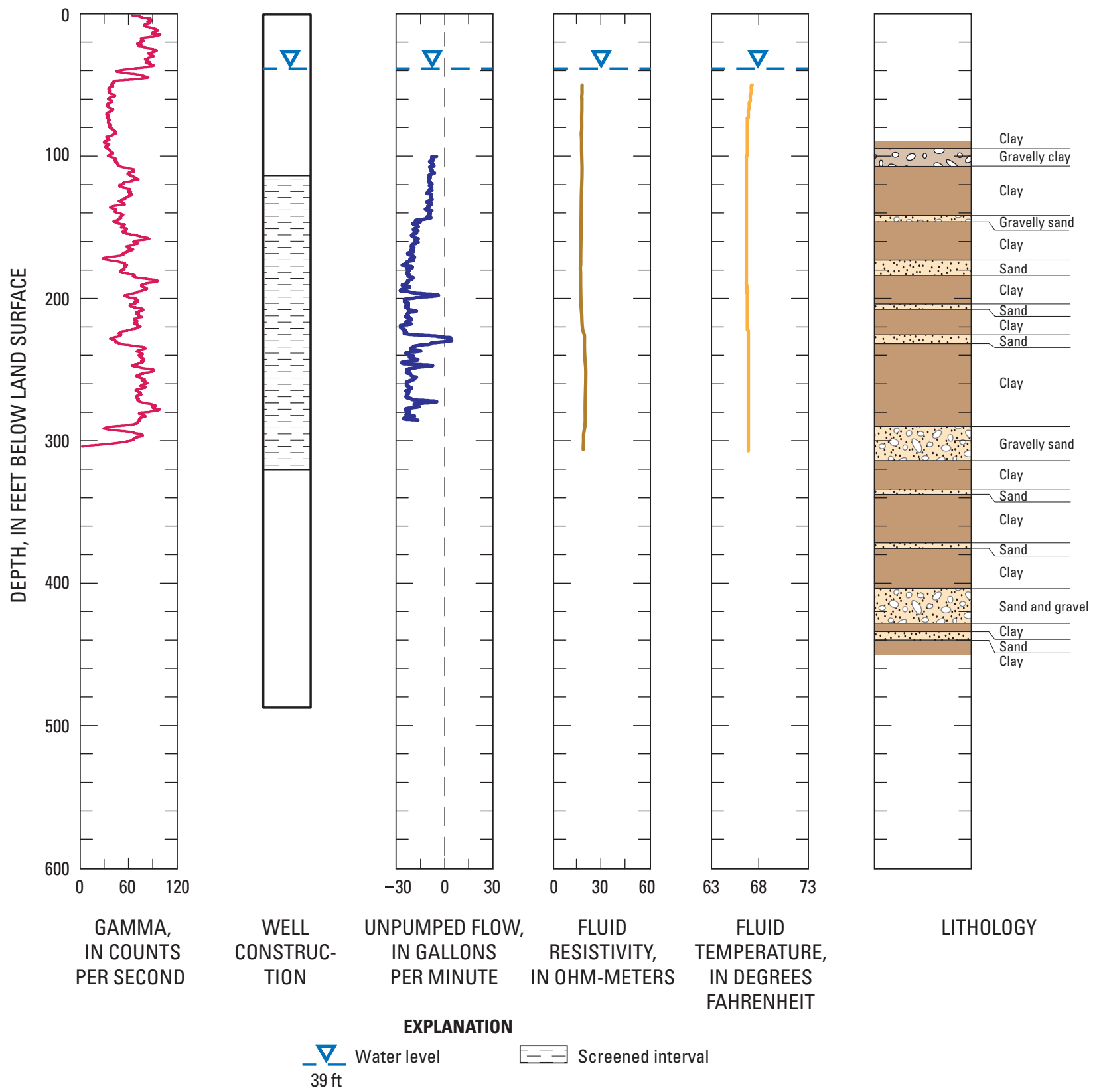

Figure 44. Gamma log, well construction, unpumped well-bore flow, fluid resistivity, fluid temperature, and lithology data from well 003N006E10A001M, Eastern San Joaquin Groundwater Subbasin, California, February 25, 2005. 
The impeller, or vertical-axis, flowmeter is the most common tool used to measure flow within production wells under pumped conditions (Hill, 1990). The impeller flowmeter relies on a mechanical impeller that turns as water flows past the impeller vanes. The number of revolutions is transmitted to the surface by electrical impulses triggered by mechanical, electrical, or magnetic counters within the flowmeter. The most commonly used impeller flowmeters are not sensitive to velocities less than about $3 \mathrm{ft} / \mathrm{min}$, although under some conditions it may be possible to measure velocities as low as $1.8 \mathrm{ft} / \mathrm{min}$ (Keys, 1990). As a result, impeller flowmeters lack the sensitivity to measure low-flow velocities typically found in unpumped wells or in the deeper parts of pumped wells. Depending on the flowmeter, at very high-flow velocities approaching $200 \mathrm{ft} / \mathrm{min}$ or more, the correlation between impeller rotation and fluid velocity may become increasingly nonlinear, and impeller flowmeter data may become inaccurate. Because these flowmeters rely on a mechanical impeller, they are sensitive to mechanical interference from debris in the well.

The EM flowmeter measures the rate of flow through the inside of a hollow, cylindrical measurement section (Paillet, 2000). Electromagnets inside the cylinder create a strong magnetic field across the inside of the cylinder. According to Faraday's Law, the voltage generated by the polar-charged water molecules passing through the magnetic field is directly proportional to its velocity (Young and Pearson, 1995). EM flowmeters are capable of measuring velocities less than $0.3 \mathrm{ft} / \mathrm{min}$ and up to a maximum velocity of approximately $250 \mathrm{ft} / \mathrm{min}$. In cased wells or smooth-walled boreholes, the sensitivity of the EM flowmeter can be further improved through the use of diverters that concentrate flow into the measurement section (Paillet, 2000). The EM flowmeter is suitable for use in both pumped and unpumped wells because of its large range. Data from fluid temperature and fluid resistivity sensors embedded within EM flowmeters are useful for hydrologic interpretations, especially in the interpretation of low-flow data from unpumped wells (Newhouse and others, 2005).

Impeller and EM flowmeter data were collected by trolling the flowmeter vertically through the well at a known rate. Impeller flowmeter data were collected at three rates: 30, 60, and $90 \mathrm{ft} / \mathrm{min}$. EM flowmeter data in pumped and unpumped wells were collected at three different rates: 5,10 , and $15 \mathrm{ft} / \mathrm{min}$. Comparison of the flowmeter response at each of the trolling rates was used as a field check on the flowmeter calibration.
The trace-pulse method provides a commercially available alternative method for collecting well-bore flow data in wells having limited access that prevents the use of traditional flowmeters (Izbicki and others, 1999). When the tracer-pulse method is used, a high-pressure hose equipped with valves and hydraulic pumps is used to inject dye into a well under pumping conditions up to $200 \mathrm{ft}$ per minute. The hose, valves, and weights are flexible and less than 2.5 centimeters in diameter. The equipment is designed to enter wells and pass through the small annular spaces between the pump and well casing. The hose is usually mounted on a reel to allow for deployment, retrieval, and storage. Prior to entering the well, the hose is filled with a fluid containing an easily measurable tracer, such as water colored with rhodamine dye. The hose is then lowered to a known depth in the well $\left(d_{1}\right)$ and a small quantity of the tracer is injected into the water using hydraulic or pneumatic pressure. The traveltime of the tracer to a detector at the surface is measured $\left(t_{1}\right)$. If rhodamine dye is used as the tracer, a fluorimeter is used to measure the arrival of the dye at the surface. The hose is then lowered to the next depth $\left(d_{2}\right)$, tracer is again injected into the water, and the traveltime $\left(t_{2}\right)$ is measured. The velocity $(V)$ is calculated as the difference in traveltimes. Assuming piston flow, the flow rate $(Q)$, given a well radius $(r)$, is calculated using the following equations (Izbicki and others, 1999):

$$
Q=\left(V p r^{2}\right)
$$

where

$$
V \text { is }\left(d_{2}-d_{1}\right) /\left(t_{2}-t_{1}\right)
$$

A series of injections at different depths is done to construct a flow profile for the well. Unlike point measurements obtained from traditional flowmeters, velocity data from the tracer-pulse method represent average values over the measurement interval.

A comparison of well-bore flow data collected from wells 1N/7E-31C1 (SSS 5) using an impellor flowmeter, an electromagnetic flowmeter, and the tracer-pulse technique is shown in figure 45. The well-bore flow data from this well shows the different techniques compare well. The resolution with depth was greater for the EM and impellor flowmeters. The resolution for the tracer-pulse data was slightly less than the flowmeter techniques, because these data are average velocities over the measurement interval rather than continuous data. 

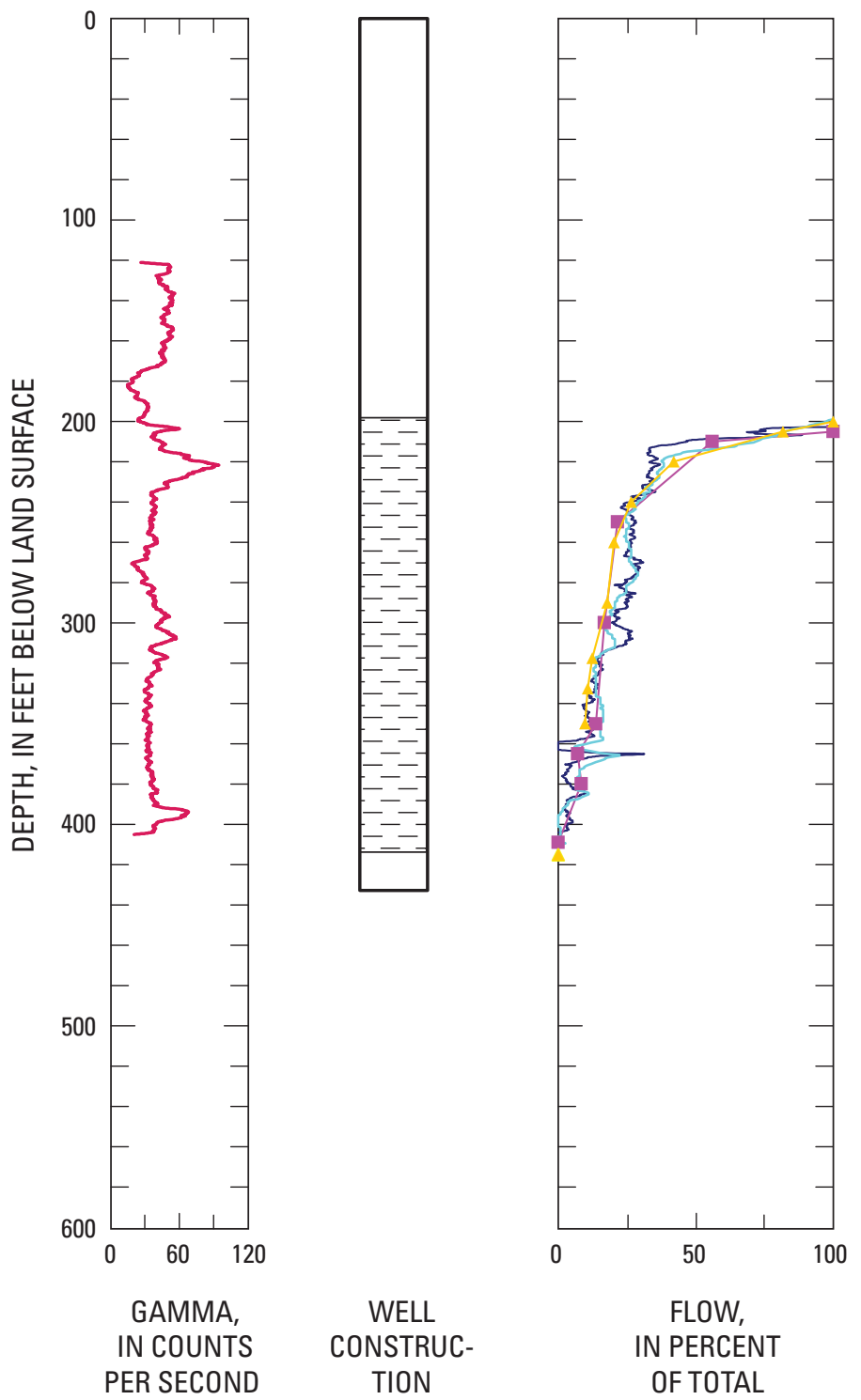

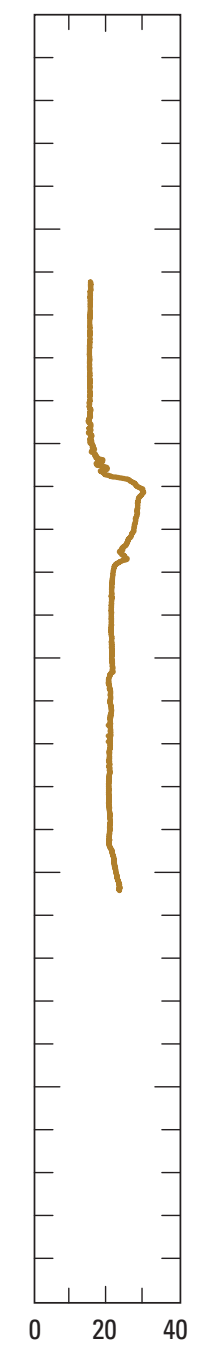

FLUID

RESISTIVITY, IN OHM-METERS

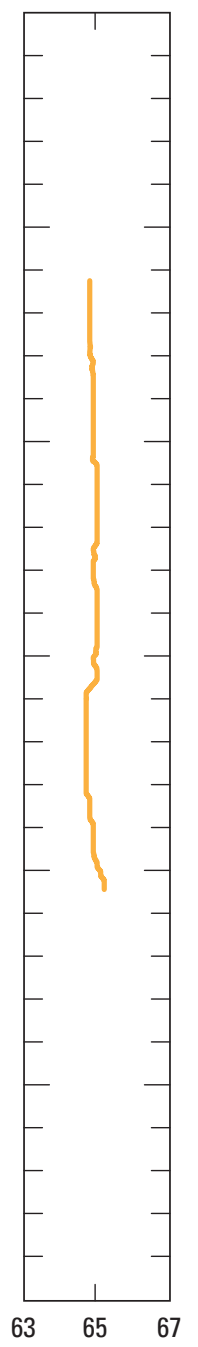

FLUID TEMPERATURE, IN DEGREES FAHRENHEIT

\section{EXPLANATION}

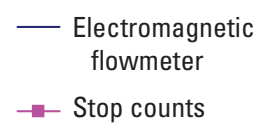

$$
\begin{aligned}
& \ldots \text { Dye log (trace- } \\
& \text { pulse method) } \\
& \text { Spinner log } \\
& \text { (Impeller flowmeter) }
\end{aligned}
$$

Screened interval

Figure 45. Gamma log, well construction, fluid resistivity, and fluid-temperature data, and flow data collected by use of three methods, from well 001N007E31C001M, Eastern San Joaquin Groundwater Subbasin, California. 


\section{Chemical Data}

Samples for chemical analysis were collected from (1) the surface discharge of pumps in selected monitoring wells and production wells, (2) different depths (depth-dependent) within production wells under pumping conditions, (3) pore water that was pressure extracted from core material collected during drilling, and (4) acid extractions from core material and cuttings collected during drilling. Sample collection, field handling procedures, and analytical methods are described in the sections below. Quality-control data also are described.

\section{Groundwater Samples}

\section{Monitoring-Well and Existing-Well Samples}

Water-quality samples were collected from multiple-well monitoring sites and private or public supply wells in this study by USGS personnel (figs. 46- 47 ). Water-quality samples were collected following the USGS field procedures outlined in the U.S. Geological Survey Field Manual for Collection of Water Quality Data (U.S. Geological Survey, 1999).

Water-level measurements were made prior to purging in wells that could be accessed. If installed, pressure transducers were removed from monitoring wells prior to sample collection. For monitoring wells, at least three wellcasing volumes were purged from the well by using a portable submersible pump. For domestic, irrigation, industrial, or public-supply wells, at least three casing volumes were purged with the existing pump. The field parameters of specific conductance, $\mathrm{pH}$, and water temperature were monitored for all wells during purging, and samples were collected only after these parameters had stabilized. Stability was attained when three successive measurements taken at intervals of 5 minutes or more differed by less than 5 percent for specific conductance, 0.1 units of $\mathrm{pH}$, and 0.2 degrees Celsius $\left({ }^{\circ} \mathrm{C}\right)$ for water temperature. Purge logs, field measurements, and other information related to sample collection are on file at USGS offices in San Diego or Sacramento, Calif.

Portable meters were used to make the field measurements for specific conductance, $\mathrm{pH}$, and alkalinity; the measurements were made using methods outlined by Wilde (2001). All meters were calibrated in the field prior to making field measurements. Dissolved-oxygen measurements were made by the colorimetric indigo-carmine method just prior to sampling. Water temperature was measured from the pump discharge using a hand-held alcohol-filled thermometer that had a full-scale accuracy of $0.5^{\circ} \mathrm{C}$ or using a built-in thermistor attached to the conductivity probe (which had an accuracy of plus or minus $0.1^{\circ} \mathrm{C}$ ). Both measuring devices were checked annually against an American Standard Laboratory and Materials standard mercury thermometer and were within $0.5^{\circ} \mathrm{C}$. Instrument $\log$ and calibration data are on file at the USGS office in San Diego, Calif.
Water samples for analyses of major ions, nutrients, and selected trace elements were pressure-filtered in the field using a membrane polyethersulfone (PES) filter capsule that had a pore size of 0.45 micrometer $(\mu \mathrm{m})$. Laboratory samples for the analysis of $\mathrm{pH}$ and specific conductance were not filtered. Most of the samples were collected in polyethylene bottles that were rinsed three times with sample water prior to filling. Samples for nutrient determinations were collected in dark, opaque polyethylene bottles and preserved on ice to inhibit bacterial growth. Samples for cation and selected trace-element concentrations were collected in acid-rinsed polyethylene bottles and preserved by acidifying the sample to a pH less than 2 using a 2-milliliter $(\mathrm{mL})$ vial of concentrated ultrapure nitric acid. Samples were shipped to the USGS National Water Quality Laboratory (NWQL) in Denver, Colorado, for analysis following standard methods outlined by Fishman and Friedman (1989), Fishman (1993), Faires (1993), Patton and Truitt (1992), Jones and Garbarino (1999), Struzeski and others (1996), Beukens, R.P. (1992), Gleason and others (1969), Coplen and others (1991), Epstein and Mayeda (1953), and Thatcher and others (1977; table 10).

Water samples for analysis of the stable isotopes hydrogen-2 (deuterium) and oxygen-18 of water were collected in $10-\mathrm{mL}$ glass vials or in $60-\mathrm{mL}$ glass bottles. The samples were not filtered. The bottles and vials were not rinsed prior to filling. The bottles and vials were sealed with a polyseal (conical) cap to minimize exchange with the atmosphere. These samples were shipped to the USGS Stable Isotope Laboratory in Reston, Virginia, for analysis according to methods outlined by Coplen and others (1991). The results of these analyses are expressed in terms of per mil values relative to Vienna Standard Mean Ocean Water (Gonfiantini, 1978). The estimate of precision (two sigma) for deuterium and oxygen-18 is 1 per mil and 0.1 per mil, respectively.

Water samples for analysis of tritium were collected in clean, dry 1-liter (L) polyethylene bottles. The samples were not filtered. Bottles were not rinsed, and care was taken not to aerate the samples during collection. Samples were sealed with a polyseal (conical) cap to minimize exchange with the atmosphere. Tritium was measured by gas scintillation (Thatcher and others, 1977) with electrolytic enrichment (Ostlund and Warner, 1962) by USGS laboratories or by laboratories under contract arrangements with the USGS. Tritium activity was reported in picocuries per liter (pCi/L). The 2-sigma detection limit for tritium ranged from 0.1 to $3.2 \mathrm{pCi} / \mathrm{L}$, and most samples had a detection limit of $0.6-1.3 \mathrm{pCi} / \mathrm{L}$. The detection limit was a function of the statistics associated with the liquid scintillation counter. In general, the longer the counting time, the better the precision and the lower the detection limit. 


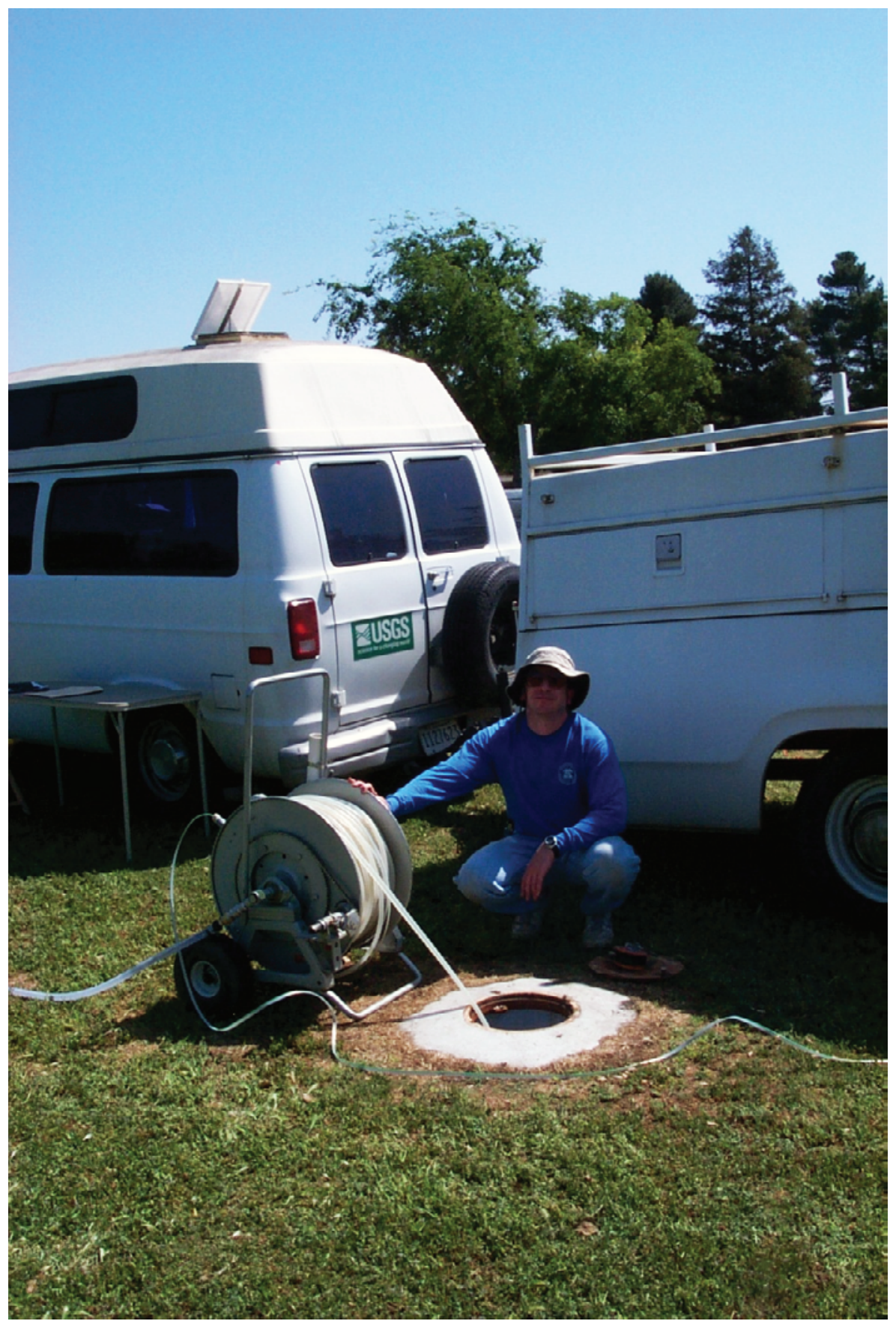

Photograph by Russell Johnson, U.S. Geological Survey, 2004.

Figure 46. Water-quality sampling using a Keck 2-inch diameter sample pump at multiple-well monitoring site 002N006E20E001M, -20E002M, and -20E003M (Swenson Park), Swenson Park, Stockton, California, April 27, 2004. 


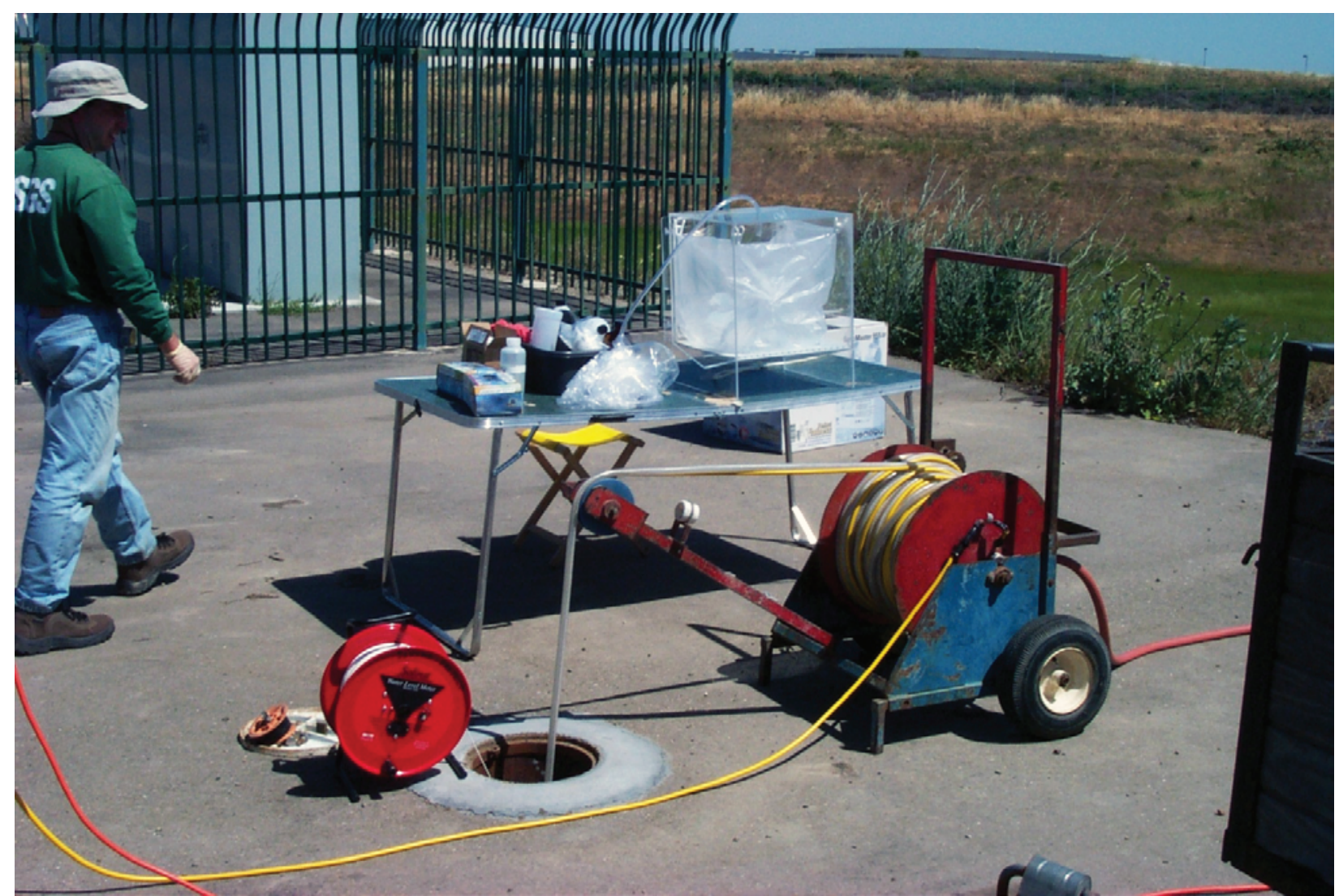

Photograph by Russell Johnson, U.S. Geological Survey, 2004.

Figure 47. Water-quality sampling using a Grundfos 2-inch diameter sample pump at Sperry Road multiple-well monitoring site 001N006E36C003M and-36C004M, near Sperry Road, Stockton, California, April 29, 2004.

Water samples intended for analysis of carbon-13/12 isotope ratio and carbon-14 isotopes were collected in 1-L amber glass bottles. Samples were filtered in the field using a membrane (PES) filter capsule with $0.45-\mu \mathrm{m}$ pore size. The bottle was bottom-filled and allowed to overflow to an amount three times the bottle volume, then sealed with Teflon-septa cap and held on ice. Carbon-13 and carbon-14 isotopes of the dissolved inorganic carbon were analyzed by USGS-approved contract laboratories using mass spectrometry (Gleason and others, 1969) and accelerator mass spectrometry analytical methods and reporting (Beukens, 1992; table 10). Results of the carbon-13 analyses are reported in per mil relative to the Vienna PeeDee Belemnite standard (Coplen, 1994). The activity of carbon-14 is reported with one-sigma estimate of precision relative to the 1950 National Bureau of Standards for oxalic acid standard (Stuiver and Polach, 1977; Wigley and Muller, 1981).

Unfiltered samples from private and public supply wells were collected by DWR personnel in 1-L bottles from a groundwater salinity monitoring network operated by the County of San Joaquin during July-August 2004. These samples were analyzed as part of this study for a limited number of constituents including chloride, bromide, iodide, barium, and boron. These chemical constituents are considered to be conservative (nonreactive) and are valuable in determining the sources of high-chloride water to wells (Izbicki and others, 2005). Samples were filtered after arrival at the USGS laboratory in San Diego, Calif., prior to shipment to the NWQL for analysis. The $\mathrm{pH}$ and specific conductance of these samples were not determined in the field, but instead were determined in the San Diego laboratory prior to filtration.

For multiple-well sites sampled as part of this study, nutrient data are provided in table 11, field measurements and water-quality data are provided in table 12, and isotopic data are provided in table 13 . For selected public-supply, industrial, agricultural, or domestic wells, nutrient data are provided in table 14, field measurements and water-quality data are provided in table 15 , and isotopic data are provided in table 16. Construction data for sampled public-supply, industrial, agricultural, or domestic wells are provided in $\underline{\text { table } 17}$, and the location of these wells is shown in figure 48. 
Table 10. Analytical methods and reporting limits for water samples submitted to the U.S. Geological Survey National Water Quality Laboratory, Denver, Colorado.

[Abbreviations: ASF, automated-segmented flow; std, standard; mg/L, milligram per liter; $\mathrm{pCi} / \mathrm{L}$, picocuries per liter; per mil, parts per thousand; $\mu \mathrm{g} / \mathrm{L}$, micrograms per liter; $\mu \mathrm{S} / \mathrm{cm}$, microsiemens per centimeter at $25^{\circ}$ Celsius; ${ }^{\circ} \mathrm{C}$, degree Celsius]

\begin{tabular}{|c|c|c|c|}
\hline Constituent & Methodology & Reporting limit & Reference \\
\hline$\overline{\mathrm{pH}}$ & $\mathrm{pH}$ electrode & 0.1 std units & Fishman and Friedman, 1989 \\
\hline Dissolved oxygen & Indigo carmine & $0.2 \mathrm{mg} / \mathrm{L}$ & CHEMetrics, Inc., Calverton, Va. \\
\hline Alkalinity & Titration with sulfuric acid & $1.0 \mathrm{mg} / \mathrm{L}$ & Fishman and Friedman, 1989 \\
\hline \multicolumn{4}{|c|}{ Major ions } \\
\hline Chloride, dissolved & Ion chromatography & $0.08 \mathrm{mg} / \mathrm{L}$ & Fishman and Friedman, 1989 \\
\hline Dissolved solids & Gravimetric, residue on evaporation at $180^{\circ} \mathrm{C}$ & $10 \mathrm{mg} / \mathrm{L}$ & Fishman and Friedman, 1989 \\
\hline Magnesium, dissolved & Inductively coupled plasma & $0.008 \mathrm{mg} / \mathrm{L}$ & Fishman, 1993 \\
\hline Potassium, dissolved & Atomic adsorption, flame & $0.09 \mathrm{mg} / \mathrm{L}$ & Fishman and Friedman, 1989 \\
\hline Silica, dissolved & Colorimetry, ASF & $0.48 \mathrm{mg} / \mathrm{L}$ & Fishman and Friedman, 1989 \\
\hline Nitrite + nitrate, dissolved & Colorimetry, ASF, cadmium reduction-diazotization & $0.047 \mathrm{mg} / \mathrm{L}$ & Fishman, 1993 \\
\hline Ammonia, dissolved & Colorimetry, ASF, salicylate-hypochlorite & $0.041 \mathrm{mg} / \mathrm{L}$ & Fishman, 1993 \\
\hline $\begin{array}{l}\text { Ammonia + organic } \\
\text { nitrogen, dissolved }\end{array}$ & Colorimetry, ASF, micro-Kjeldahl digestion & $0.10 \mathrm{mg} / \mathrm{L}$ & Patton and Truitt, 1992 \\
\hline Phosphorus, dissolved & Colorimetry, ASF, micro-Kjeldahl digestion & $0.05 \mathrm{mg} / \mathrm{L}$ & Patton and Truitt, 1992 \\
\hline Orthophosphate, dissolved & Colorimetry, ASF, phosphomolybdate & $0.018 \mathrm{mg} / \mathrm{L}$ & Fishman, 1993 \\
\hline \multicolumn{4}{|c|}{ Trace elements } \\
\hline Arsenic, dissolved & Graphite furnace atomic adsorption & $2.0 \mu \mathrm{g} / \mathrm{L}$ & Jones and Garbarino, 1999 \\
\hline Barium, dissolved & Inductively coupled plasma & $0.9 \mu \mathrm{g} / \mathrm{L}$ & Fishman, 1993 \\
\hline Boron, dissolved & Inductively coupled plasma & $13 \mu \mathrm{g} / \mathrm{L}$ & Struzeski and others, 1996 \\
\hline \multicolumn{4}{|c|}{ Isotopes } \\
\hline Carbon-13/carbon-12 & Mass spectrometry & 0.15 per mil & Gleason and others, 1969 \\
\hline Deuterium/protium & Mass spectrometry & 2 per mil & Coplen and others, 1991 \\
\hline Oxygen-18/oxygen-16 & Mass spectrometry & 0.2 per mil & Epstein and Mayeda, 1953 \\
\hline Tritium & Electrolytic enrichment and liquid scintillation & $1.0 \mathrm{pCi} / \mathrm{L}$ & Thatcher and others, 1977 \\
\hline
\end{tabular}




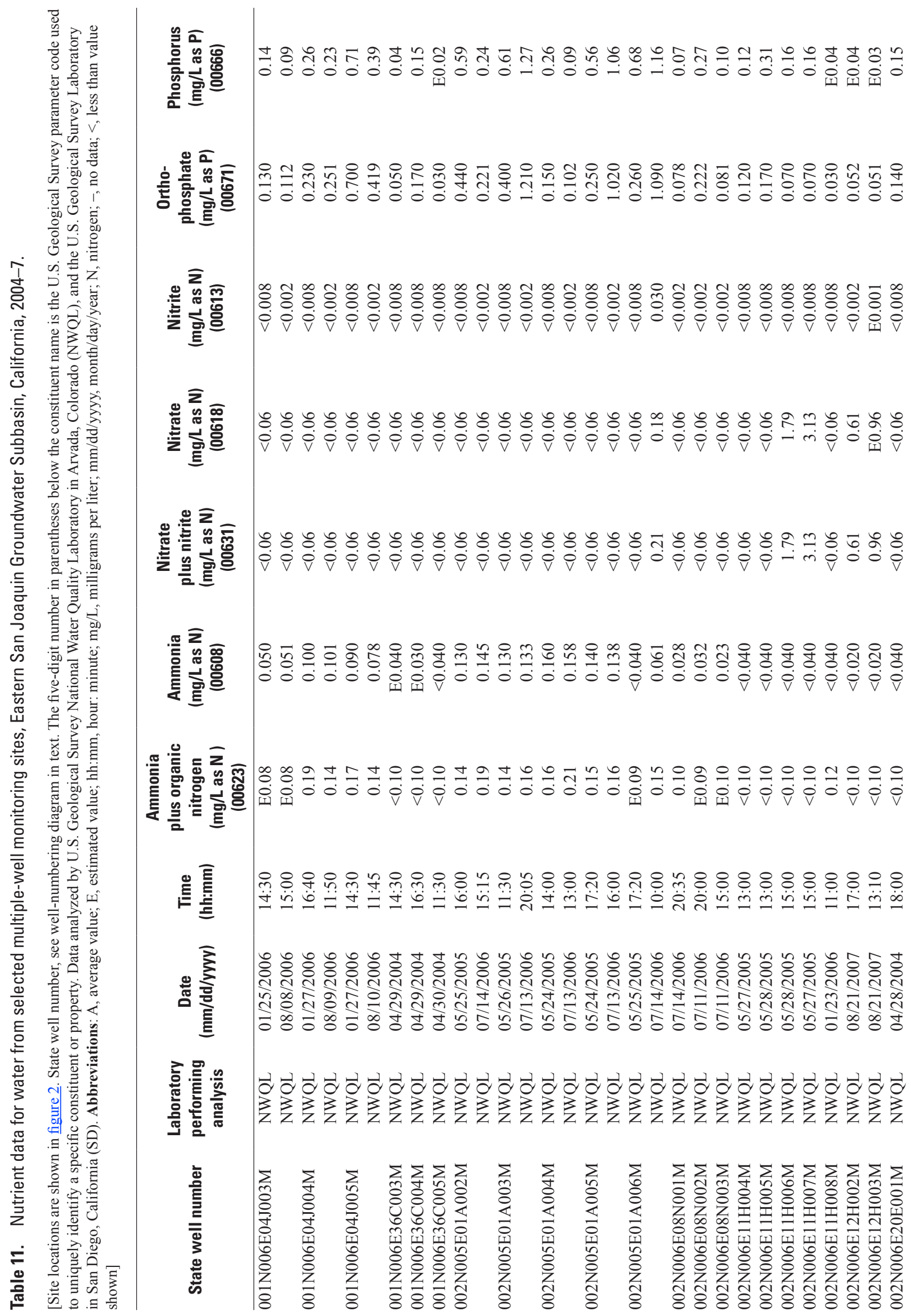




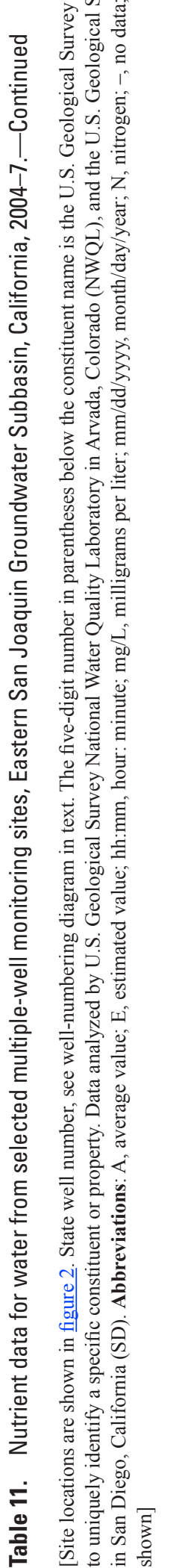

\begin{tabular}{|c|c|c|}
\hline 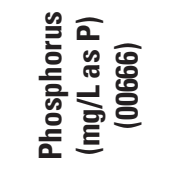 & 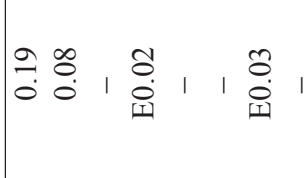 & 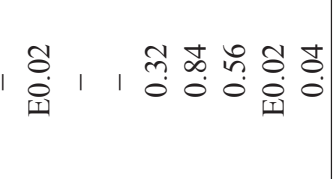 \\
\hline 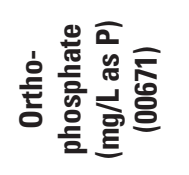 & 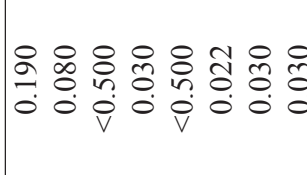 & 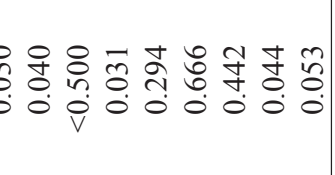 \\
\hline 宔 & 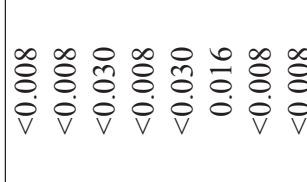 & 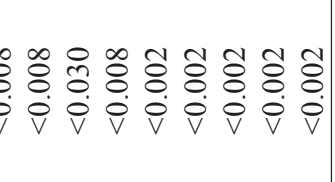 \\
\hline 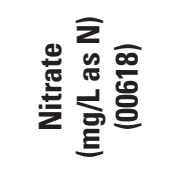 & 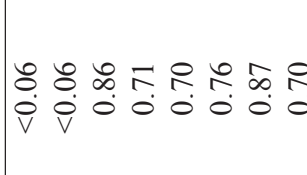 & 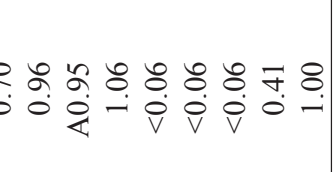 \\
\hline 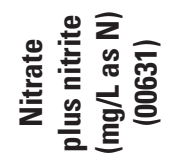 & 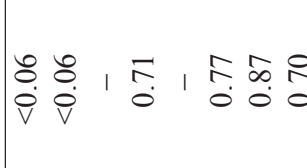 & 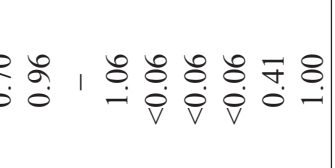 \\
\hline 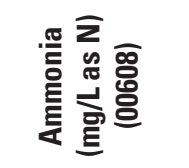 & 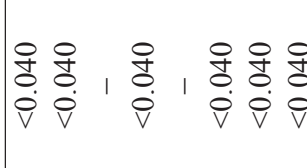 & 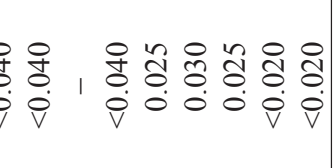 \\
\hline 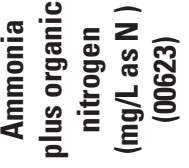 & 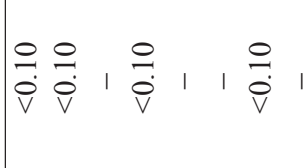 & 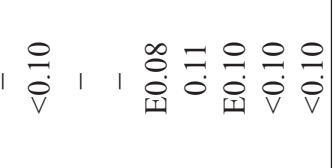 \\
\hline 总豆 & 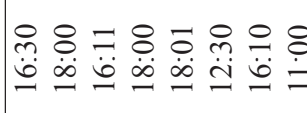 & 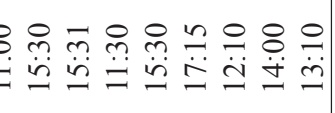 \\
\hline 离 & 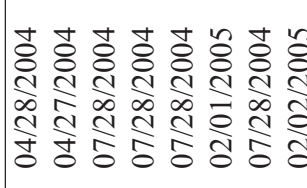 & 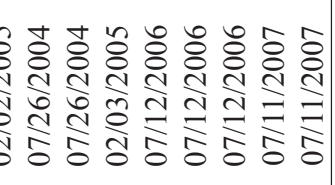 \\
\hline 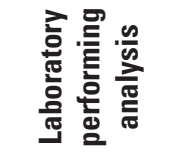 & 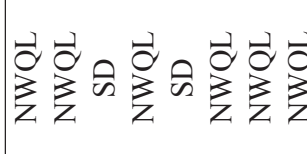 & 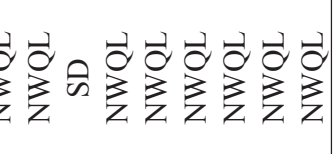 \\
\hline 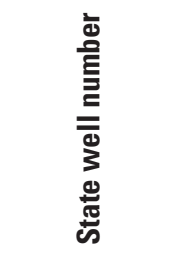 & 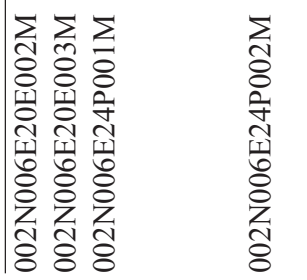 & 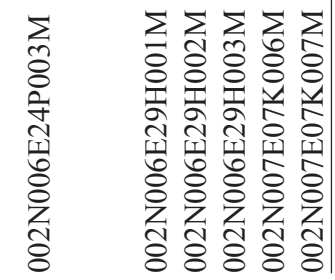 \\
\hline
\end{tabular}




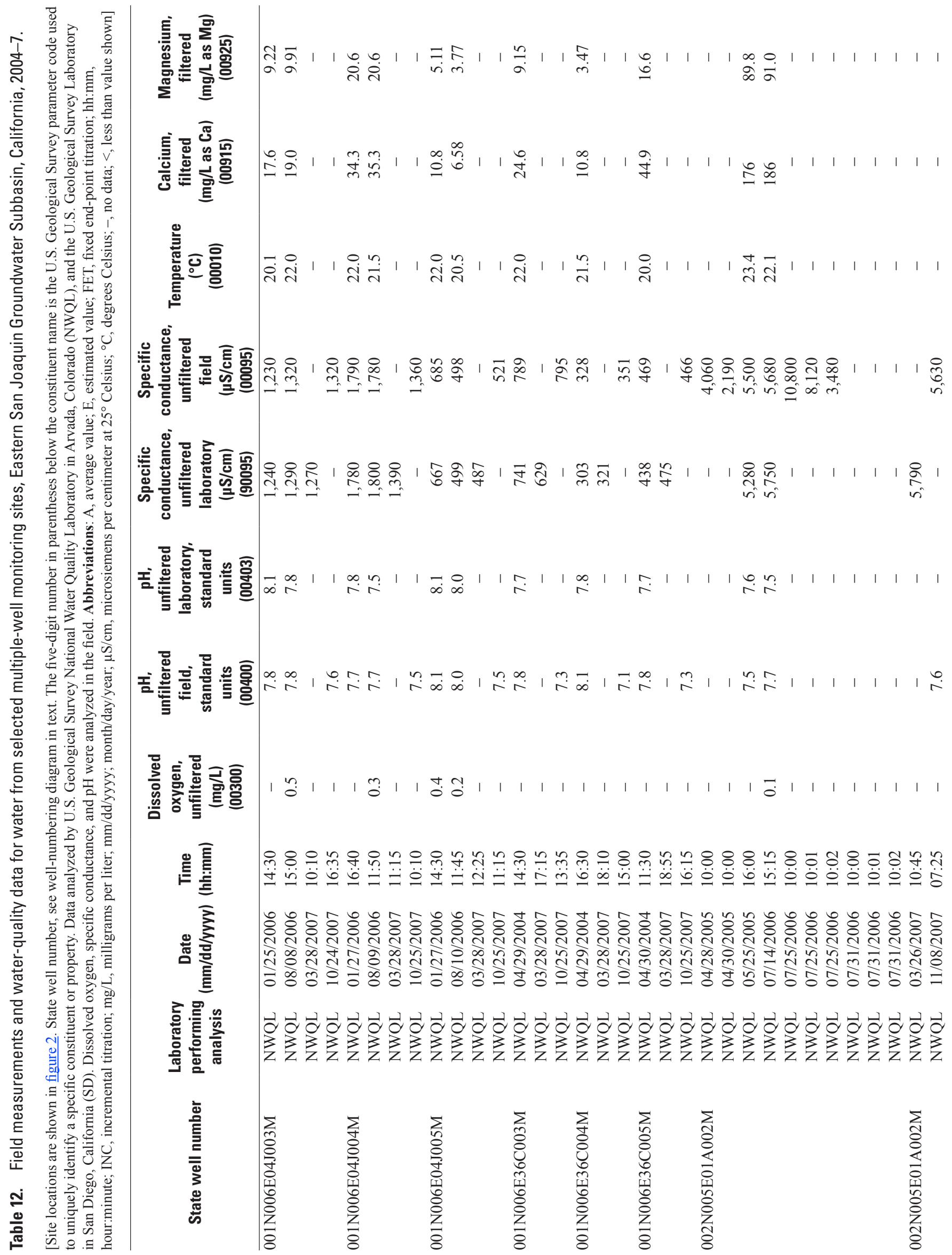




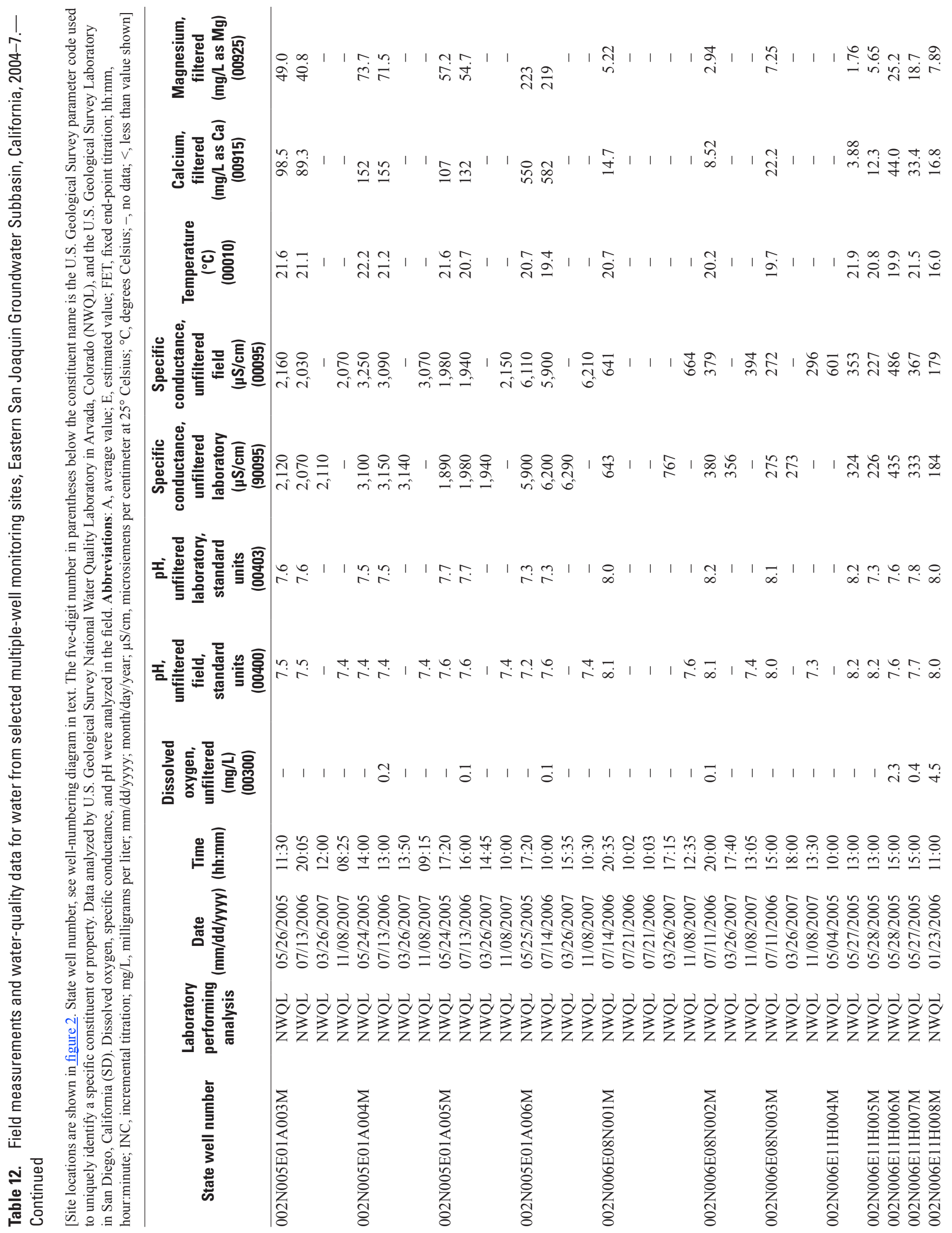




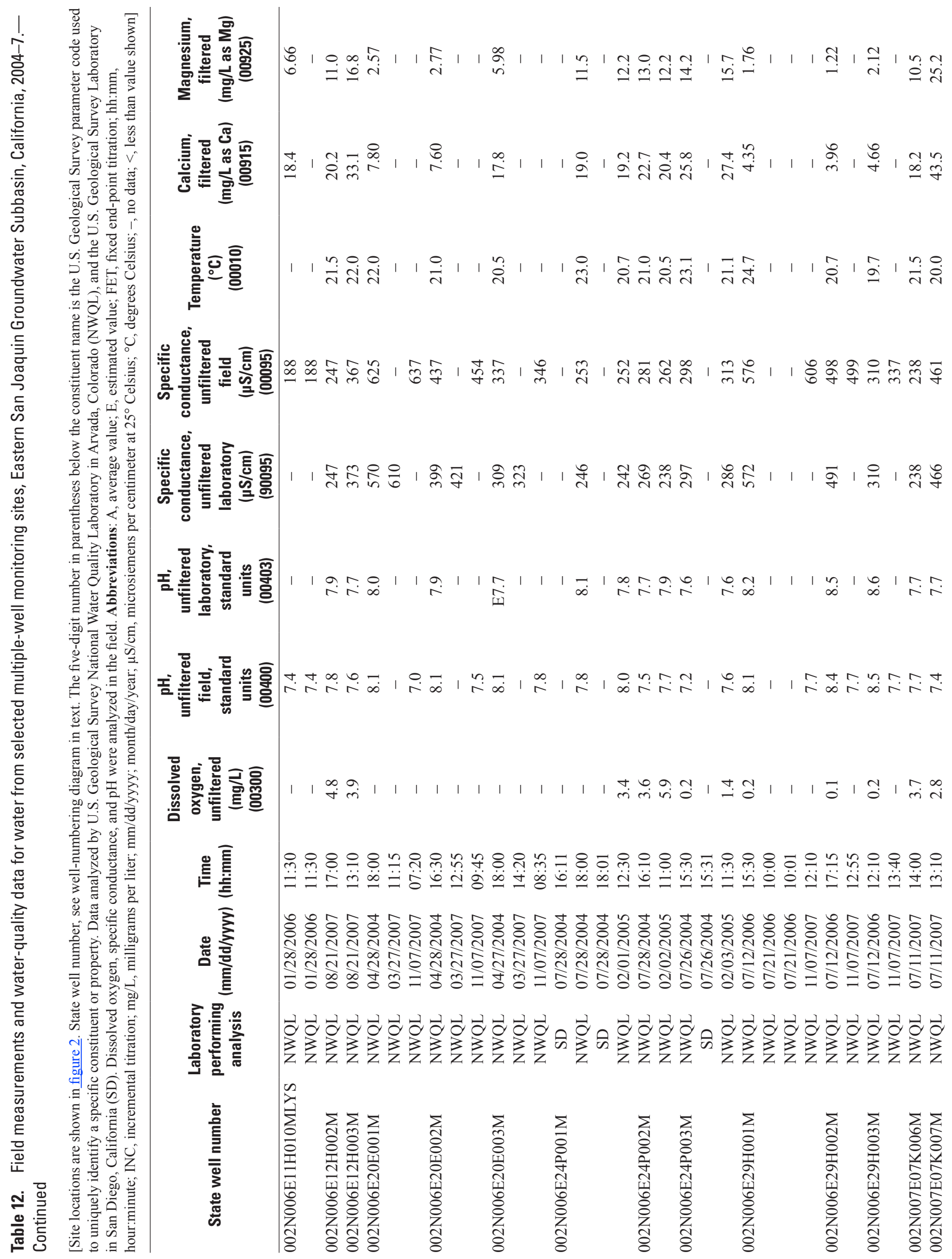




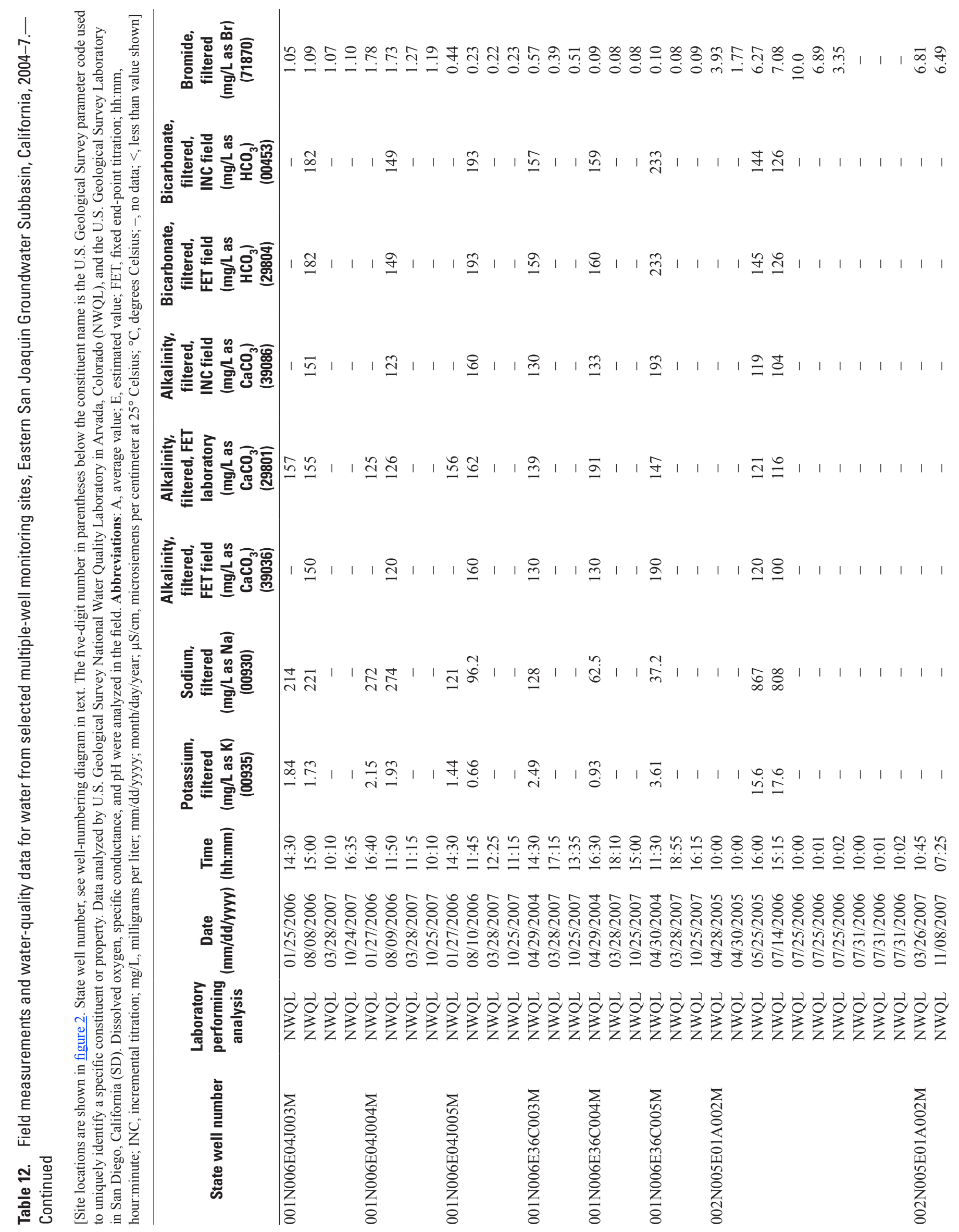




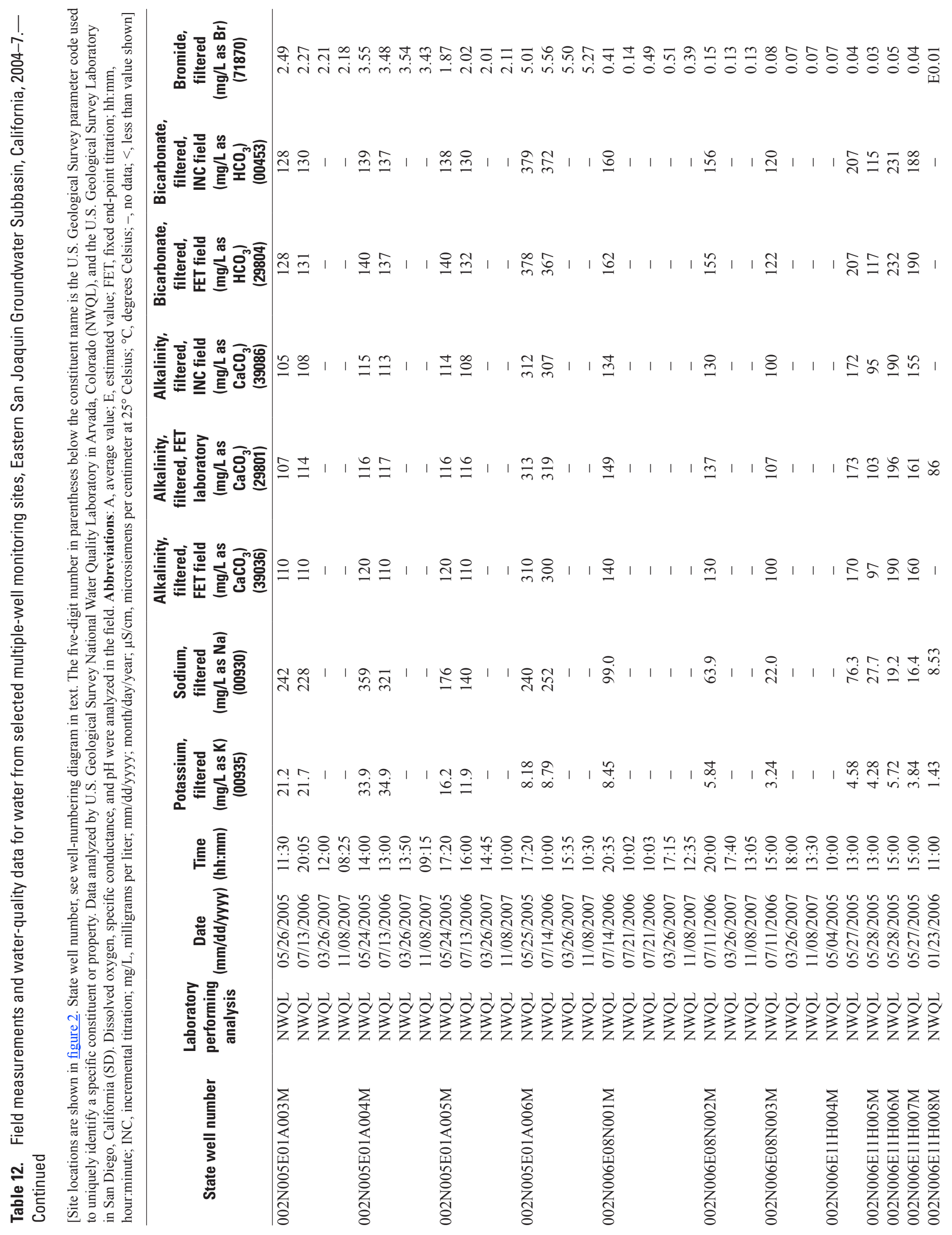




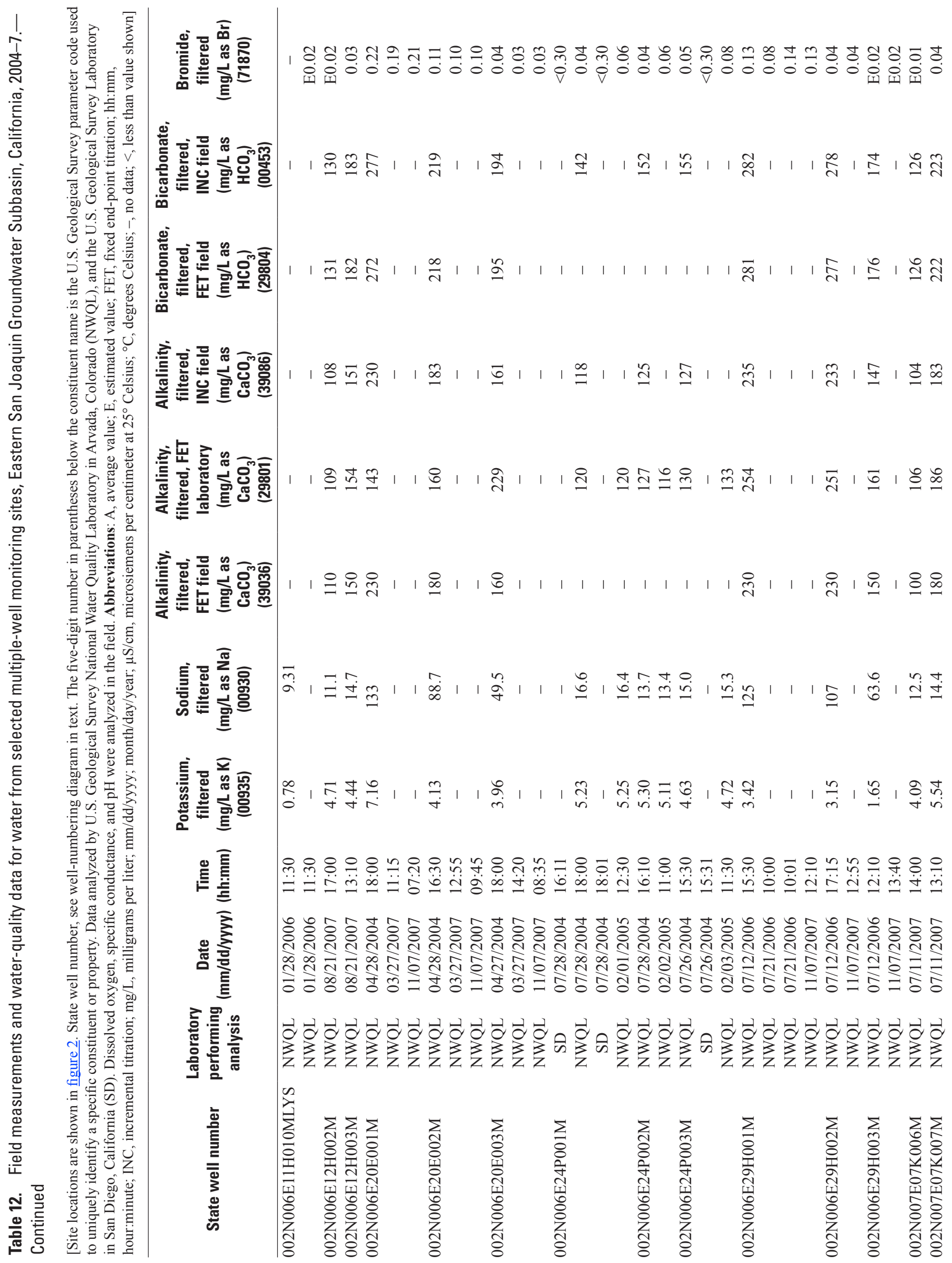




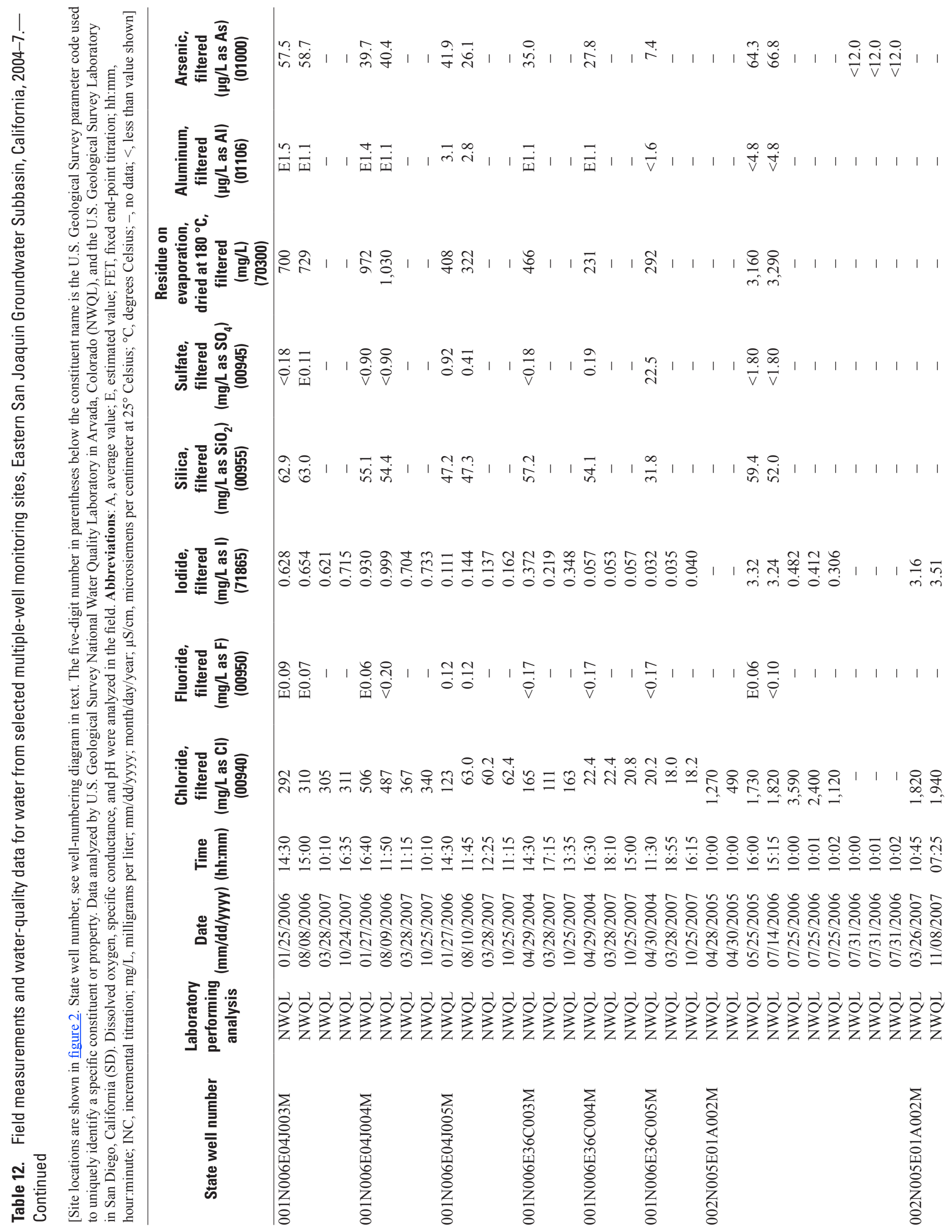




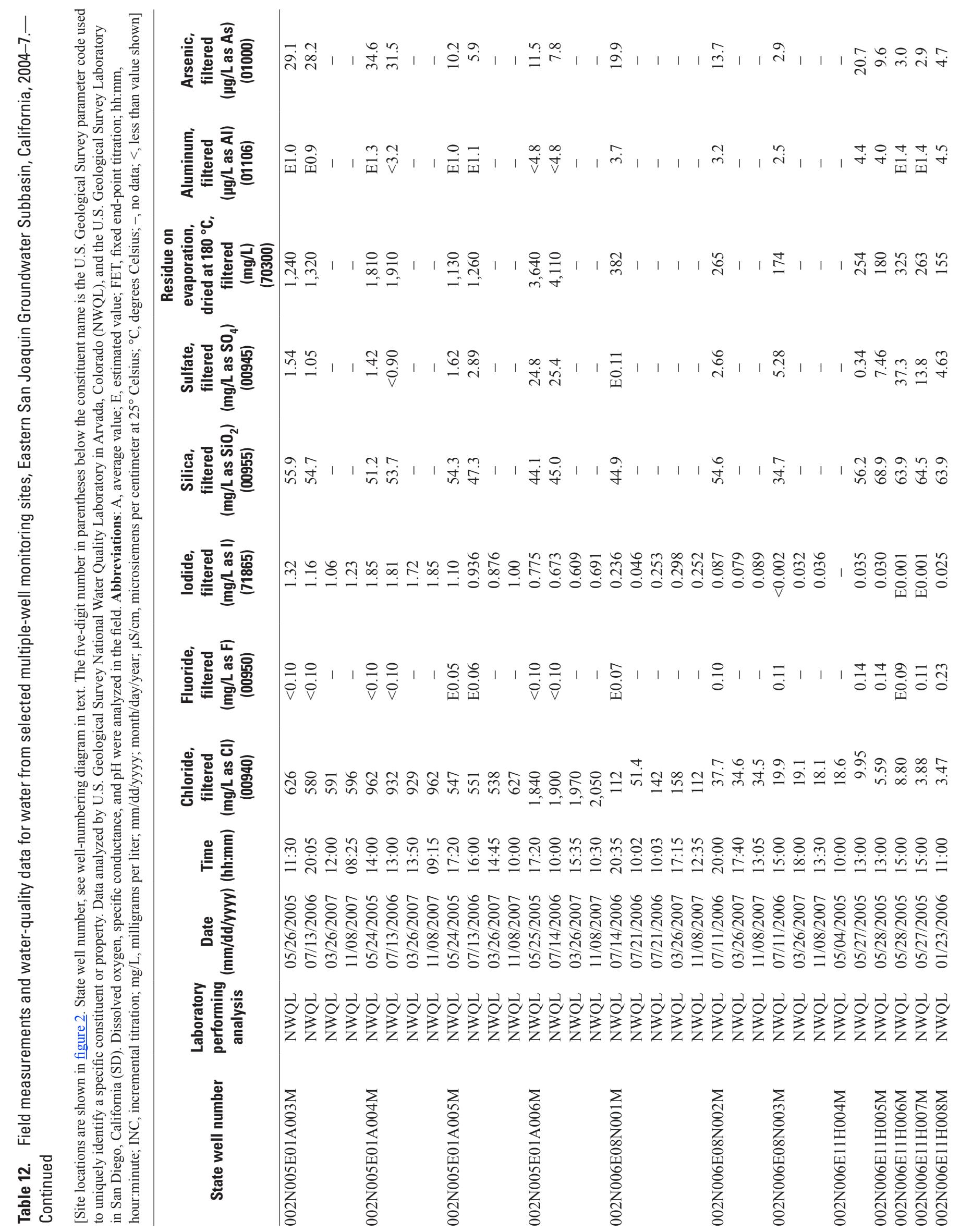




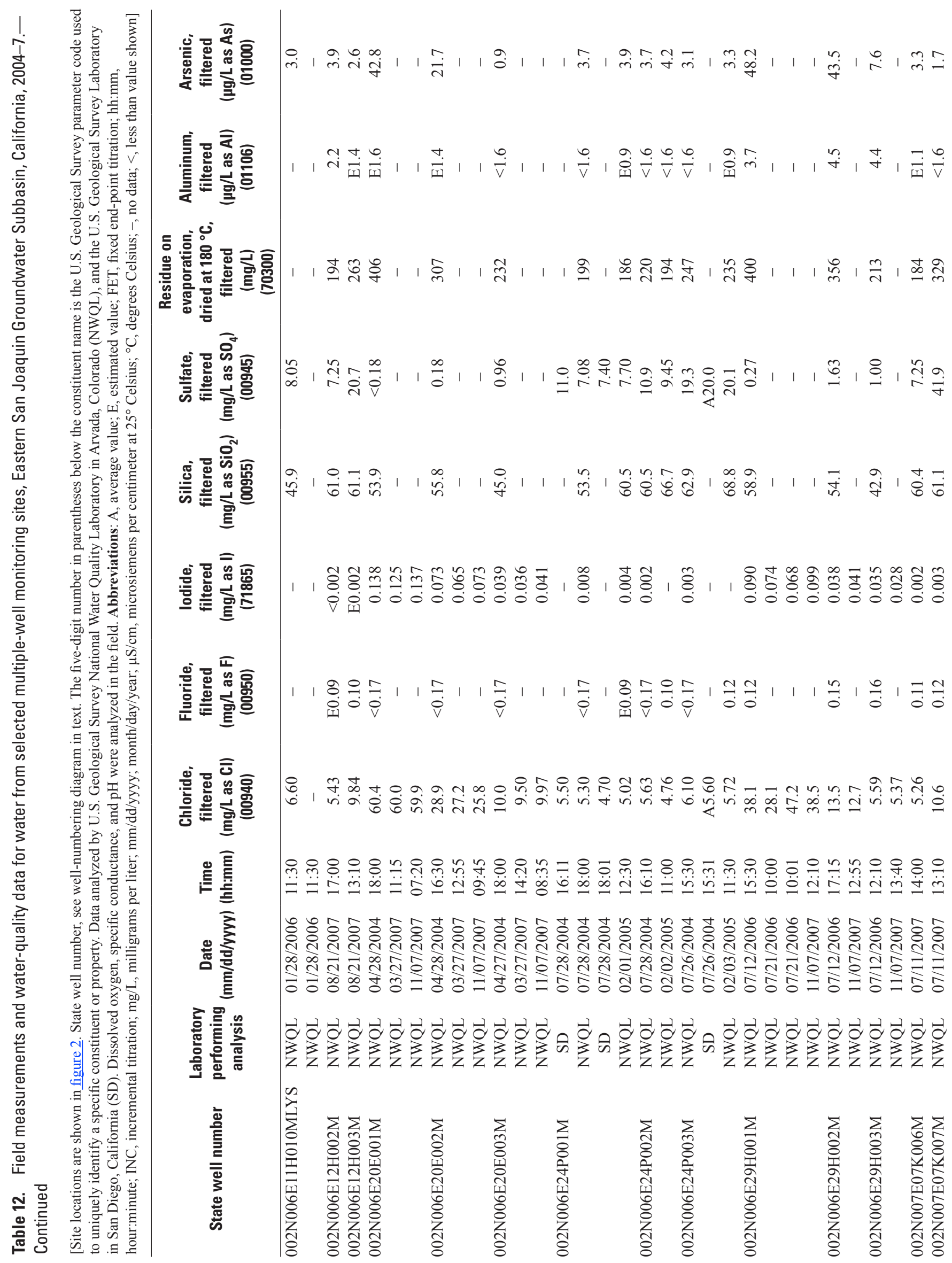




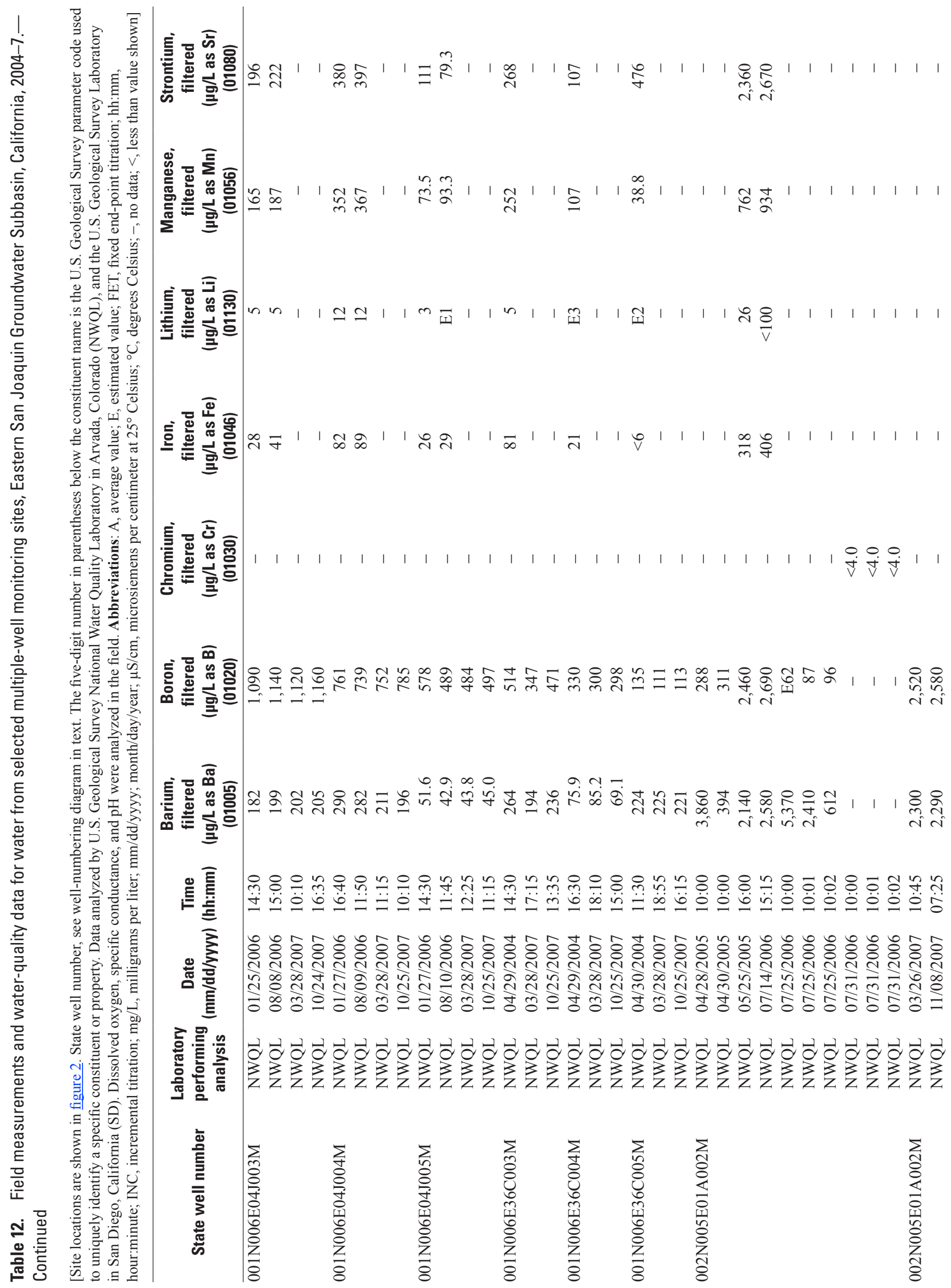




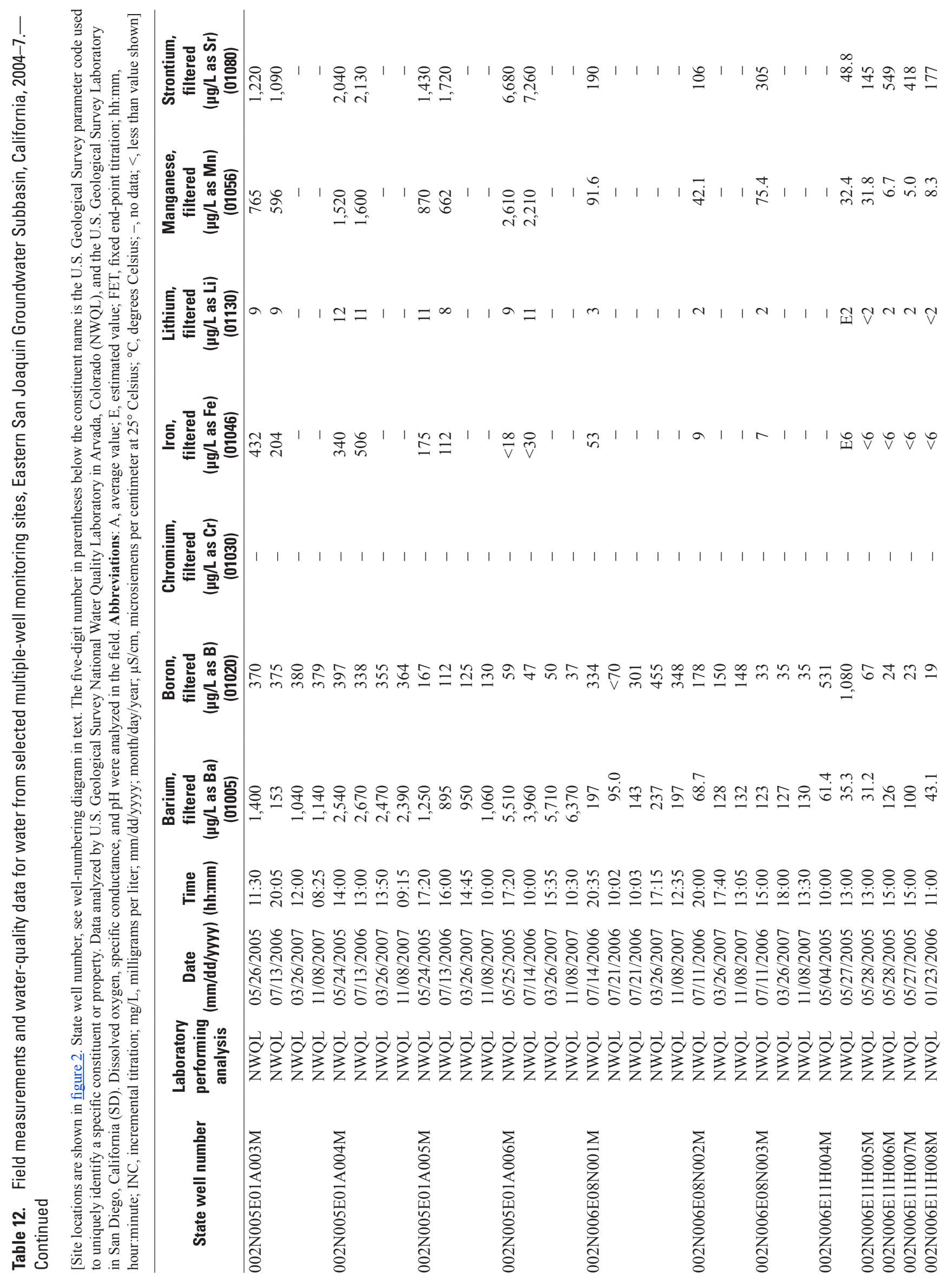




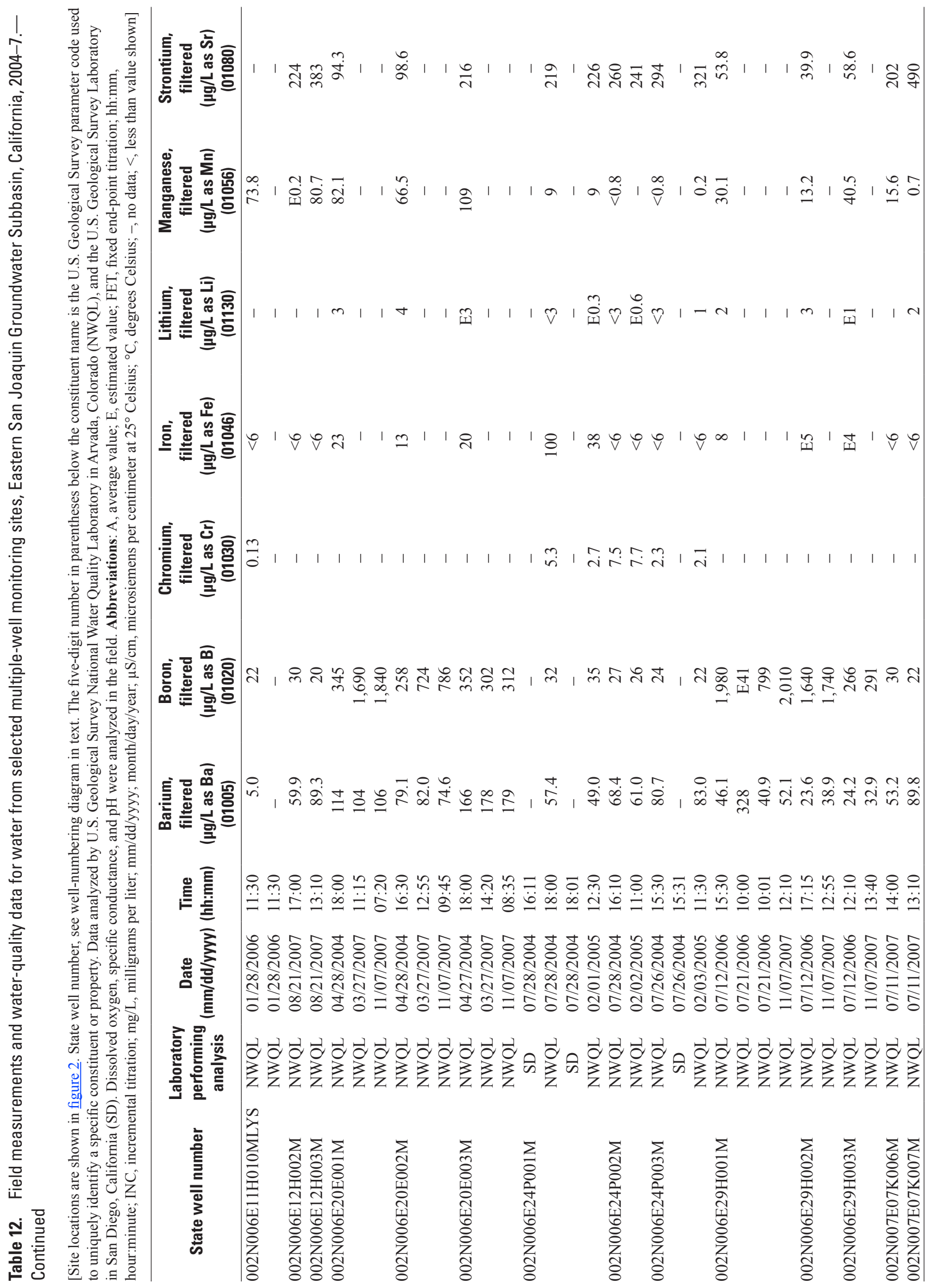


Table 13. Isotopic data for water from selected multiple-well monitoring sites, Eastern San Joaquin Groundwater Subbasin, California, 2004-7.

[Site locations are shown in figure 2. State well number, see well-numbering diagram in text. The five-digit number in parentheses below the constituent name is the U.S. Geological Survey parameter code used to uniquely identify a specific constituent or property. Deuterium/protium and oxygen-18/16 analyzed at USGS National Research Program, Stable Isotope Laboratory, Reston, Virginia. Carbon age analyzed by University of Waterloo, Isotope Laboratory, Waterloo, Ontario, Canada. Tritium analyzed at University of Miami, Tritium Laboratory, Miami, Florida. Dates sites were drilled given in table 1. Abbreviations: hh:mm, hour:minute; mm/dd/yyyy, month/day/year; per mil, parts per thousand; $\mathrm{pCi} / \mathrm{L}$, picocuries per liter; -, no data]

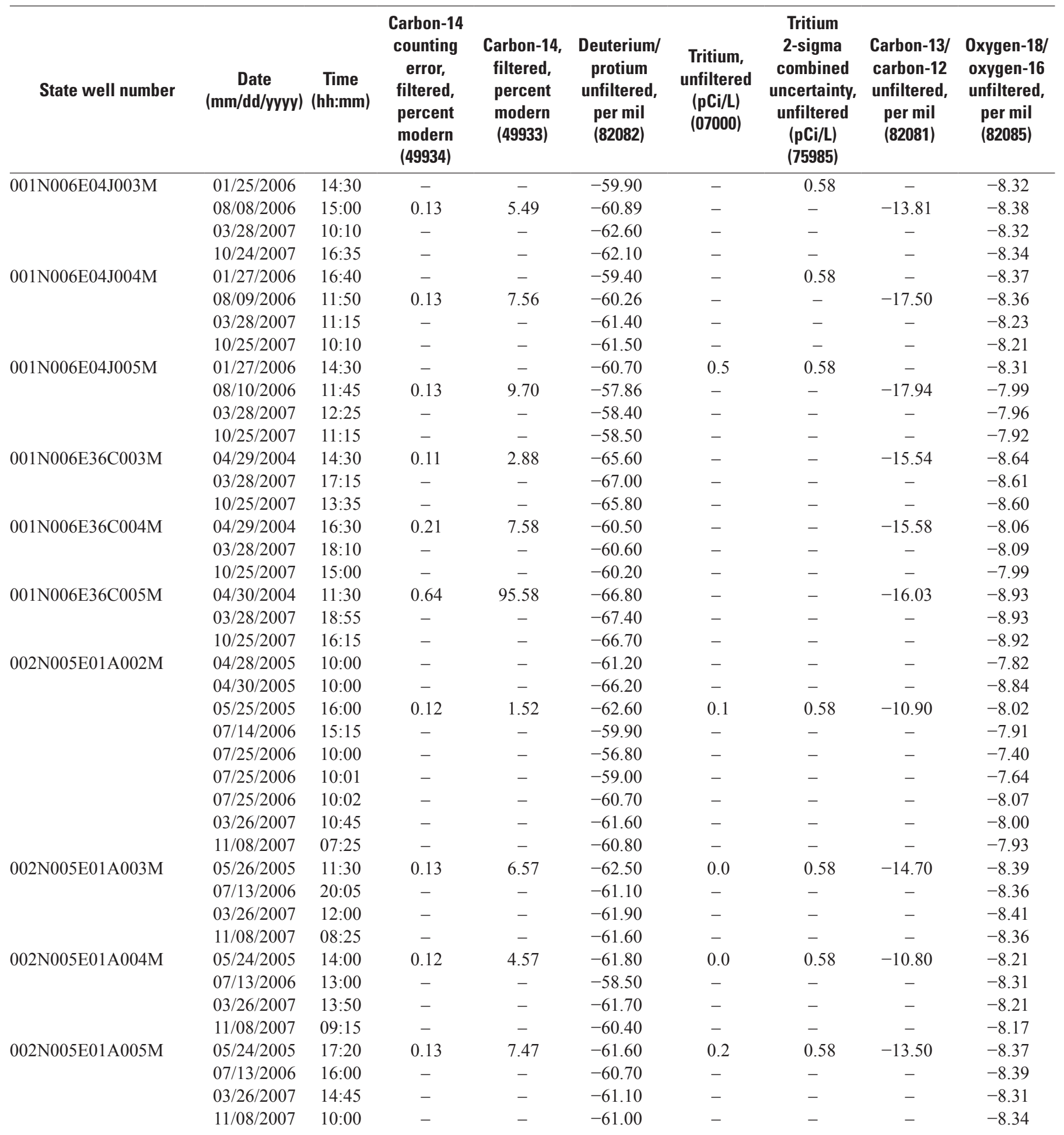


Table 13. Isotopic data for water from selected multiple-well monitoring sites, Eastern San Joaquin Groundwater Subbasin, California, 2004-7.-Continued

[Site locations are shown in figure 2. State well number, see well-numbering diagram in text. The five-digit number in parentheses below the constituent name is the U.S. Geological Survey parameter code used to uniquely identify a specific constituent or property. Deuterium/protium and oxygen-18/16 analyzed at USGS National Research Program, Stable Isotope Laboratory, Reston, Virginia. Carbon age analyzed by University of Waterloo, Isotope Laboratory, Waterloo, Ontario, Canada. Tritium analyzed at University of Miami, Tritium Laboratory, Miami, Florida. Dates sites were drilled given in table 1. Abbreviations: hh:mm, hour:minute; mm/dd/yyyy, month/day/year; per mil, parts per thousand; $\mathrm{pCi} / \mathrm{L}$, picocuries per liter; -, no data]

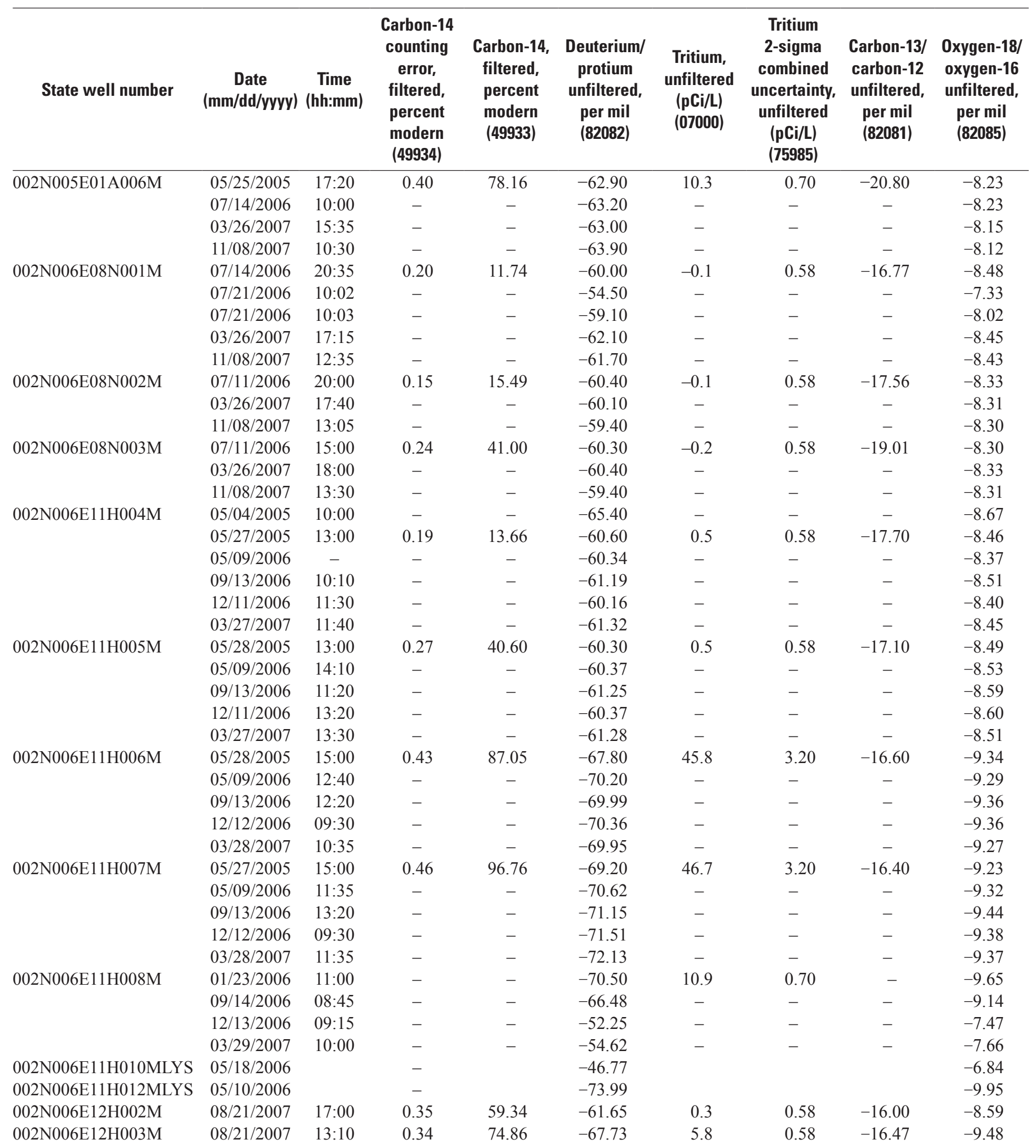


Table 13. Isotopic data for water from selected multiple-well monitoring sites, Eastern San Joaquin Groundwater Subbasin, California, 2004-7.-Continued

[Site locations are shown in figure 2. State well number, see well-numbering diagram in text. The five-digit number in parentheses below the constituent name is the U.S. Geological Survey parameter code used to uniquely identify a specific constituent or property. Deuterium/protium and oxygen-18/16 analyzed at USGS National Research Program, Stable Isotope Laboratory, Reston, Virginia. Carbon age analyzed by University of Waterloo, Isotope Laboratory, Waterloo, Ontario, Canada. Tritium analyzed at University of Miami, Tritium Laboratory, Miami, Florida. Dates sites were drilled given in table 1. Abbreviations: hh:mm, hour:minute; mm/dd/yyyy, month/day/year; per mil, parts per thousand; $\mathrm{pCi} / \mathrm{L}$, picocuries per liter; -, no data]

\begin{tabular}{|c|c|c|c|c|c|c|c|c|c|}
\hline State well number & $\begin{array}{c}\text { Date } \\
\text { (mm/dd/yyyy) }\end{array}$ & $\begin{array}{c}\text { Time } \\
\text { (hh:mm) }\end{array}$ & $\begin{array}{c}\text { Carbon-14 } \\
\text { counting } \\
\text { error, } \\
\text { filtered, } \\
\text { percent } \\
\text { modern } \\
\text { (49934) }\end{array}$ & $\begin{array}{c}\text { Carbon-14, } \\
\text { filtered, } \\
\text { percent } \\
\text { modern } \\
\text { (49933) }\end{array}$ & $\begin{array}{c}\text { Deuterium/ } \\
\text { protium } \\
\text { unfiltered, } \\
\text { per mil } \\
\text { (82082) }\end{array}$ & $\begin{array}{c}\text { Tritium, } \\
\text { unfiltered } \\
\text { (pCi/L) } \\
(07000)\end{array}$ & $\begin{array}{c}\text { Tritium } \\
\text { 2-sigma } \\
\text { combined } \\
\text { uncertainty, } \\
\text { unfiltered } \\
\text { (pCi/L) } \\
(75985)\end{array}$ & $\begin{array}{c}\text { Carbon-13/ } \\
\text { carbon-12 } \\
\text { unfiltered, } \\
\text { per mil } \\
\text { (82081) }\end{array}$ & $\begin{array}{c}\text { Oxygen-18/ } \\
\text { oxygen-16 } \\
\text { unfiltered, } \\
\text { per mil } \\
\text { (82085) }\end{array}$ \\
\hline 002N006E20E001M & $11 / 07 / 2007$ & $07: 20$ & - & - & -62.50 & - & - & - & -8.50 \\
\hline \multirow[t]{3}{*}{ 002N006E20E002M } & $04 / 28 / 2004$ & $16: 30$ & 0.16 & 7.80 & -61.70 & - & - & -16.34 & -8.38 \\
\hline & $03 / 27 / 2007$ & $12: 55$ & - & - & -60.80 & - & - & - & -8.36 \\
\hline & $11 / 07 / 2007$ & $09: 45$ & - & - & -60.00 & - & - & - & -8.34 \\
\hline \multirow[t]{2}{*}{ 002N006E20E003M } & $04 / 27 / 2004$ & $18: 00$ & 0.24 & 13.54 & -59.30 & - & - & -20.55 & -8.25 \\
\hline & $03 / 27 / 2007$ & $14: 20$ & - & - & -59.50 & - & - & - & -8.17 \\
\hline \multirow[t]{2}{*}{ 002N006E24P002M } & $07 / 28 / 2004$ & $16: 10$ & 0.27 & 54.24 & -60.60 & 8.8 & 0.58 & -22.05 & -8.51 \\
\hline & $02 / 02 / 2005$ & $11: 00$ & 0.41 & 79.10 & -60.60 & 6.1 & 1.00 & -16.24 & -8.49 \\
\hline \multirow[t]{2}{*}{ 002N006E24P003M } & $07 / 26 / 2004$ & $15: 30$ & 0.44 & 107.1 & -59.60 & 33.6 & 1.92 & -16.70 & -8.27 \\
\hline & $02 / 03 / 2005$ & $11: 30$ & 0.50 & 110.0 & -59.30 & 33.3 & 1.90 & -15.66 & -8.17 \\
\hline \multirow[t]{4}{*}{ 002N006E29H001M } & $07 / 12 / 2006$ & $15: 30$ & 0.11 & 4.16 & -63.50 & 0.1 & 0.58 & -12.04 & -8.66 \\
\hline & $07 / 21 / 2006$ & $10: 00$ & - & - & -44.50 & - & - & - & -5.00 \\
\hline & $07 / 21 / 2006$ & $10: 01$ & - & - & -63.50 & - & - & - & -8.42 \\
\hline & $11 / 07 / 2007$ & $12: 10$ & - & - & -64.20 & - & - & - & -8.58 \\
\hline \multirow[t]{2}{*}{ 002N006E29H002M } & $07 / 12 / 2006$ & $17: 15$ & 0.14 & 5.63 & -63.40 & -0.3 & 0.58 & -12.41 & -8.58 \\
\hline & $11 / 07 / 2007$ & $12: 55$ & - & - & -63.30 & - & - & - & -8.60 \\
\hline 002N006E29H003M & $07 / 12 / 2006$ & $12: 10$ & 0.15 & 16.36 & -58.10 & -0.1 & 0.58 & -18.11 & -8.22 \\
\hline
\end{tabular}




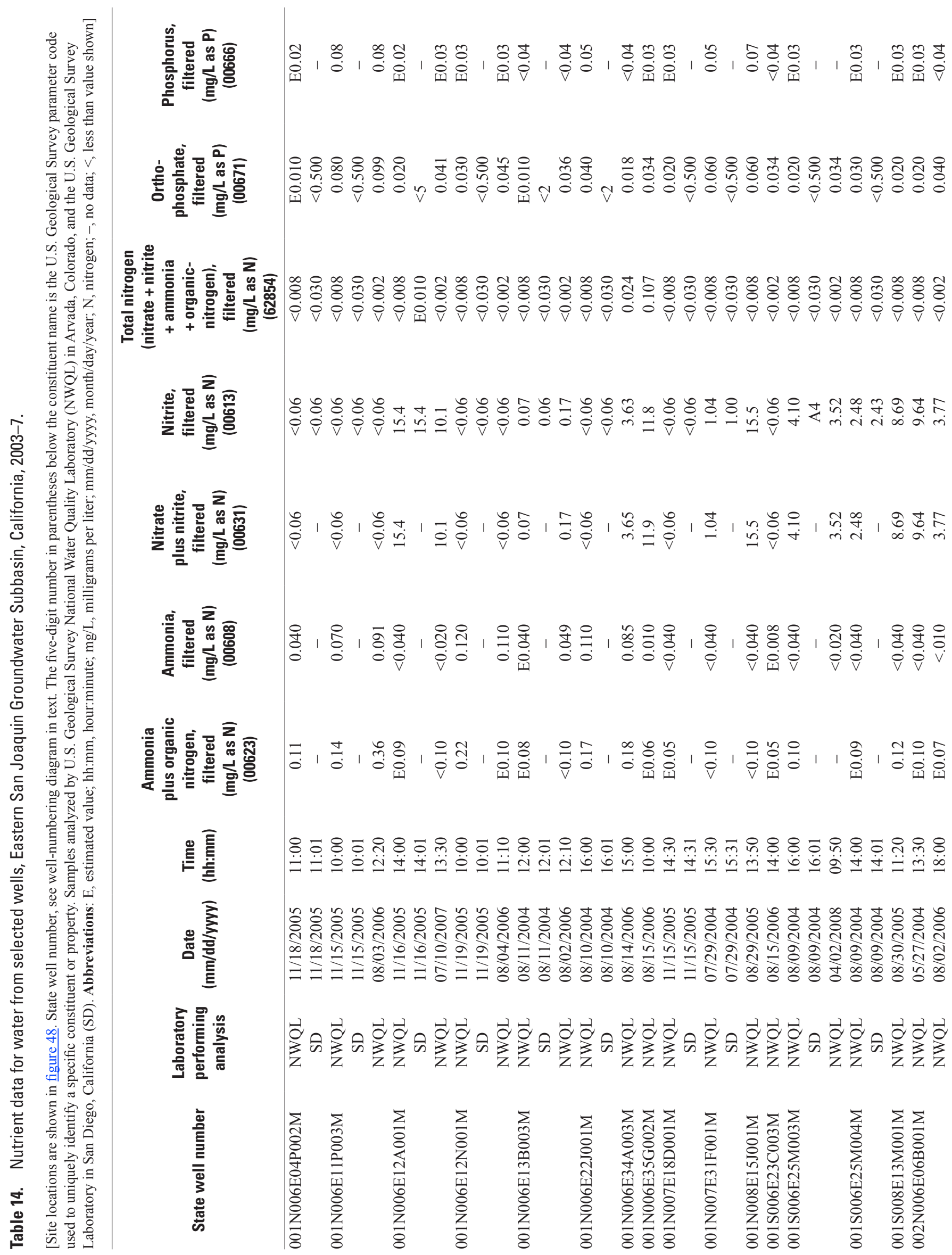




\begin{tabular}{|c|c|c|c|c|}
\hline 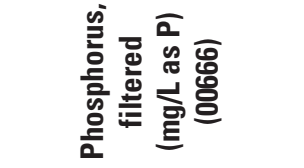 & \multicolumn{4}{|c|}{ 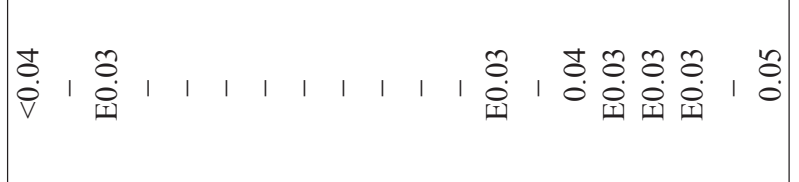 } \\
\hline 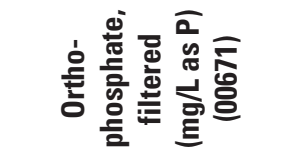 & \multicolumn{4}{|c|}{ 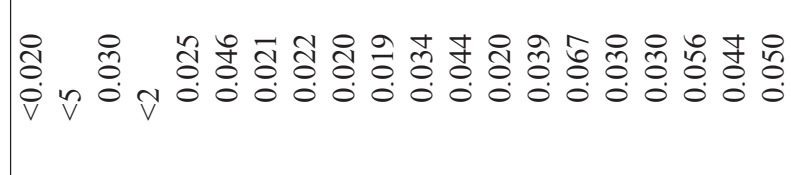 } \\
\hline 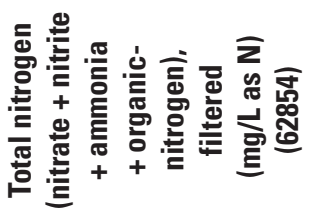 & \multicolumn{4}{|c|}{ 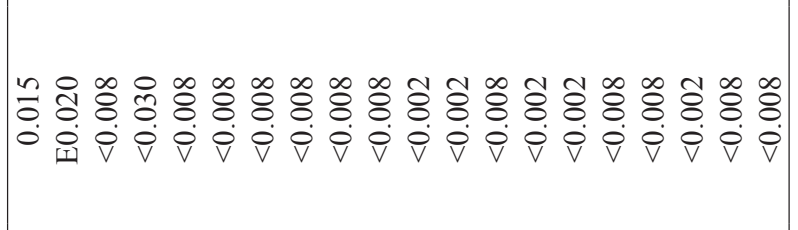 } \\
\hline 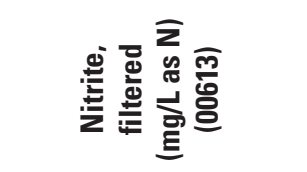 & \multicolumn{4}{|c|}{ 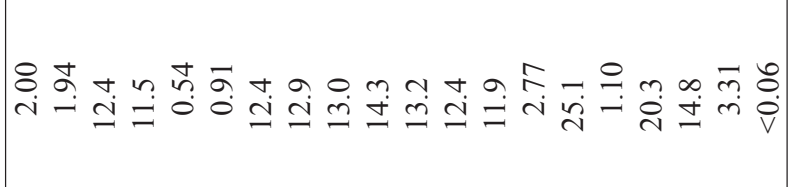 } \\
\hline 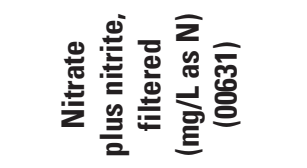 & \multicolumn{4}{|c|}{ 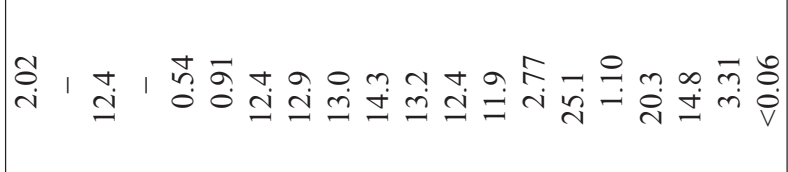 } \\
\hline 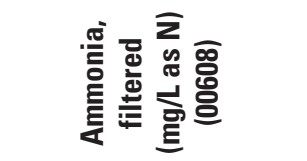 & \multicolumn{4}{|c|}{ 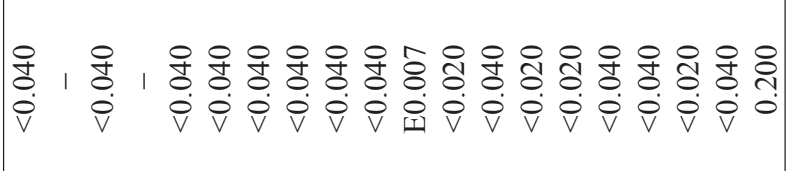 } \\
\hline 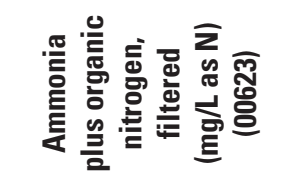 & 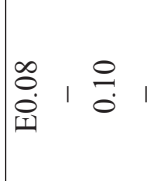 & 111 & 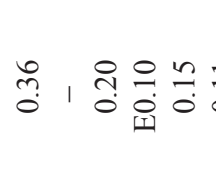 & ĩֶ \\
\hline 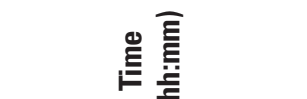 & \multirow{2}{*}{\multicolumn{4}{|c|}{ 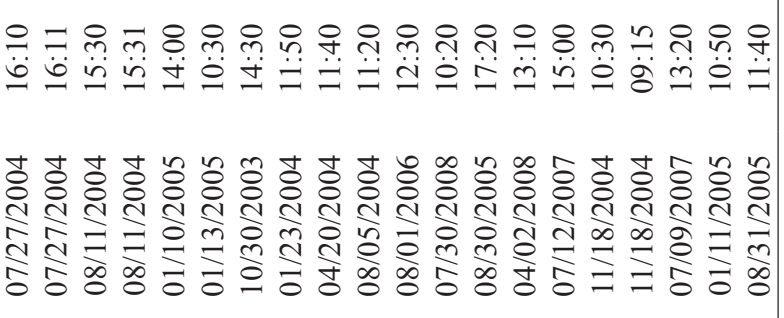 }} \\
\hline 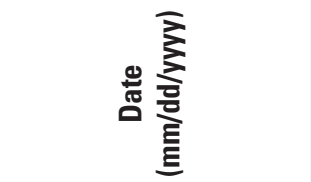 & & & & \\
\hline 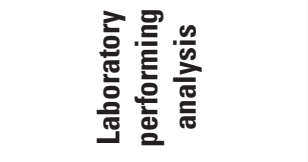 & \multicolumn{4}{|c|}{ 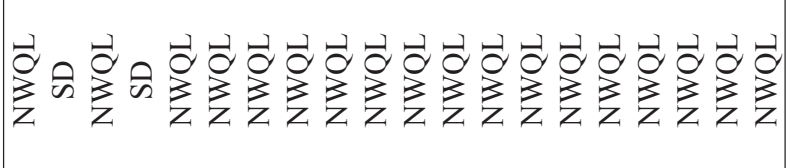 } \\
\hline 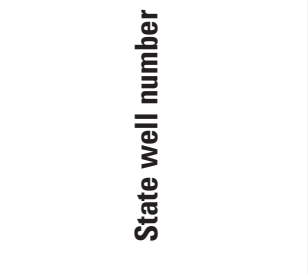 & 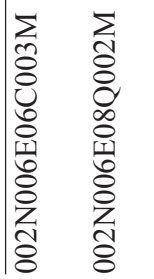 & 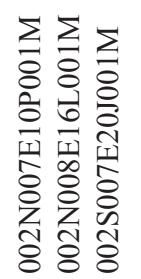 & 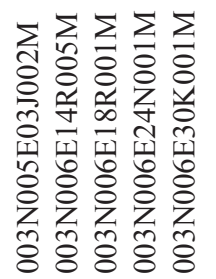 & 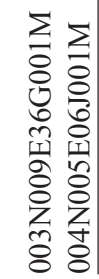 \\
\hline
\end{tabular}




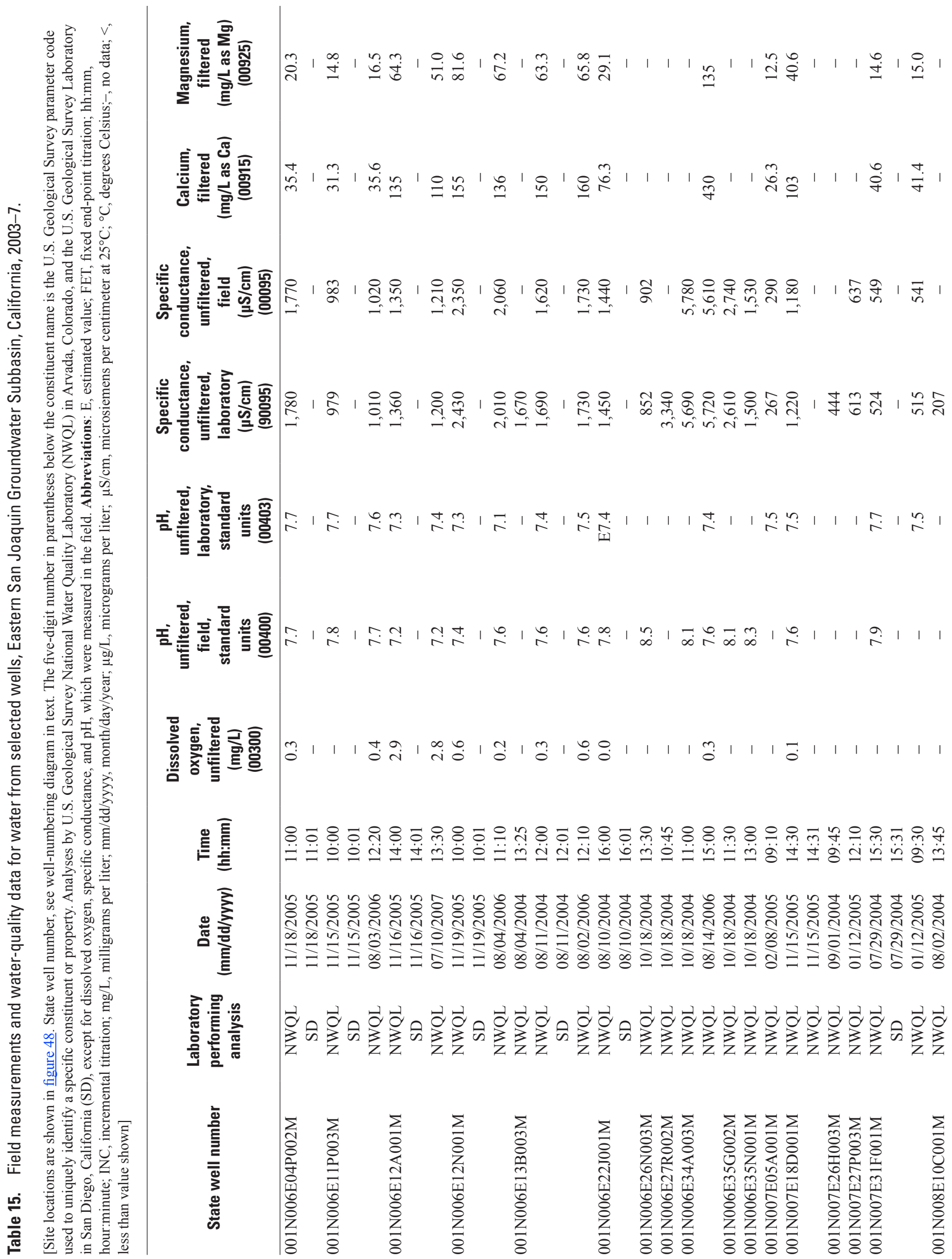



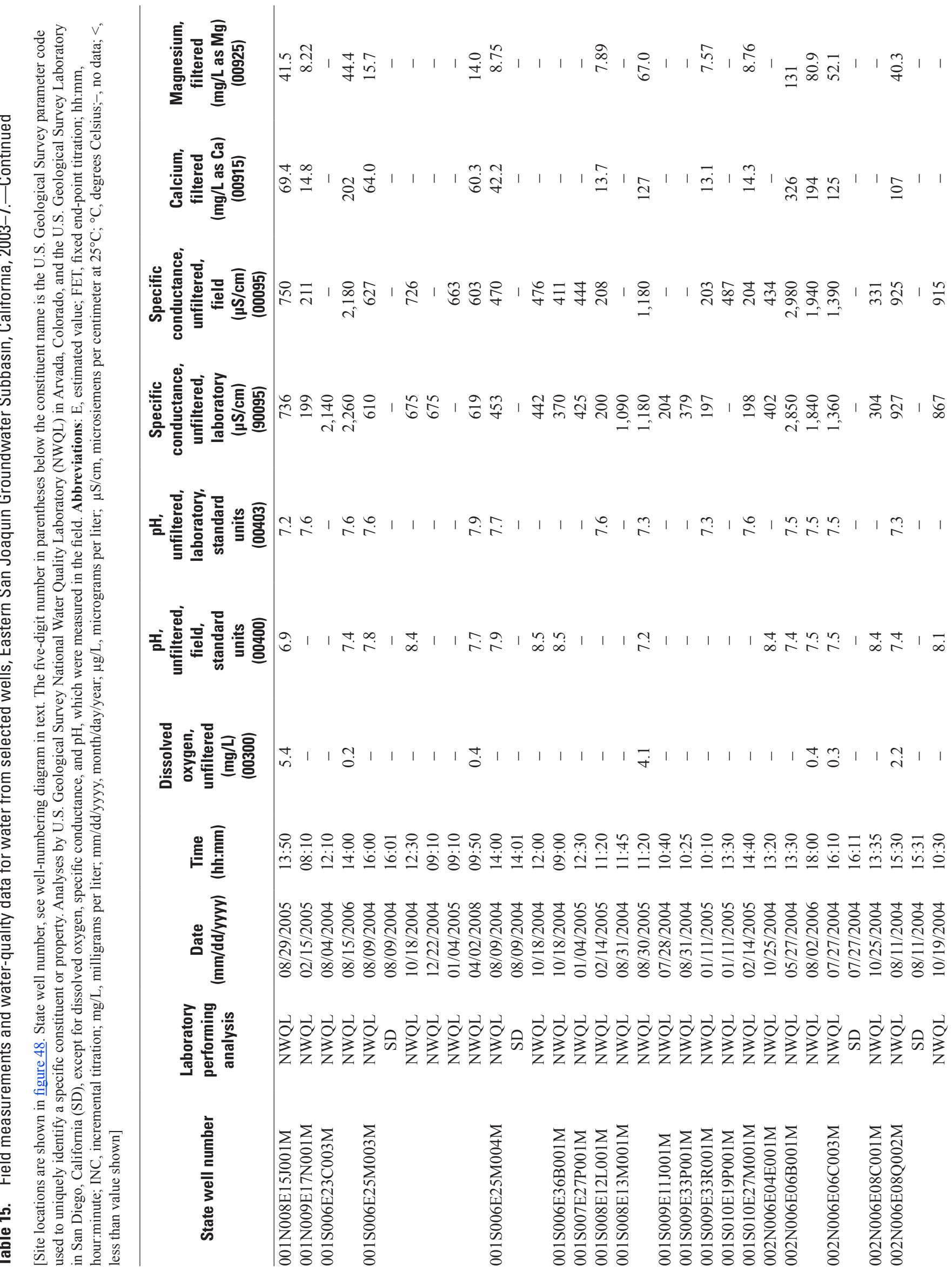

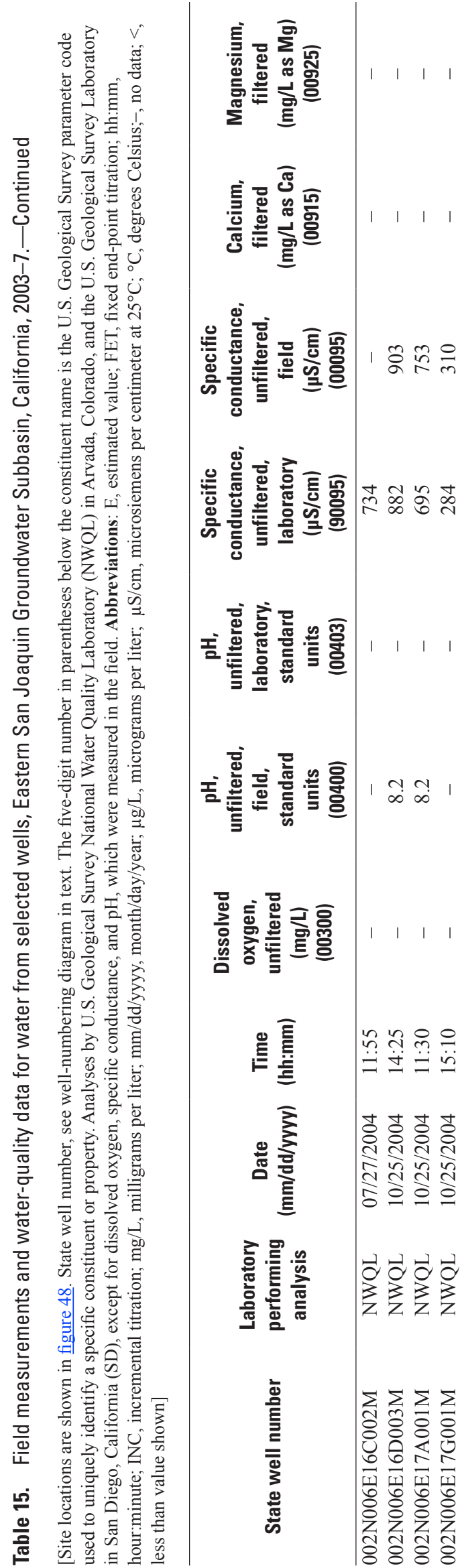

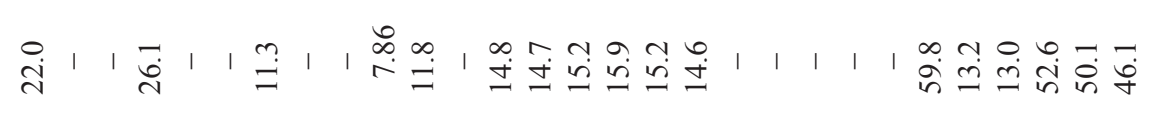

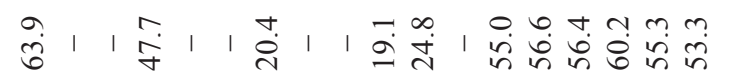

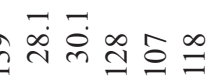

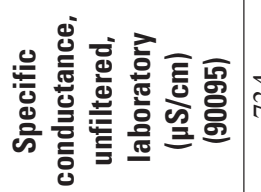

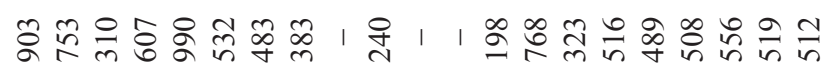

|

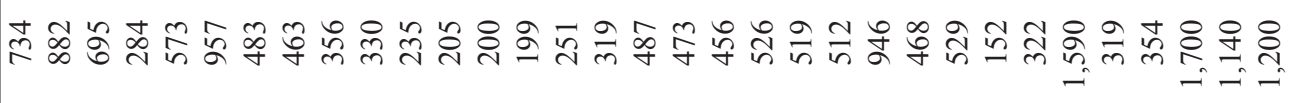

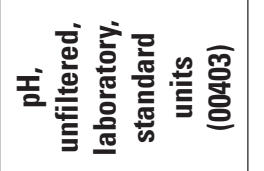

1 1 1 1

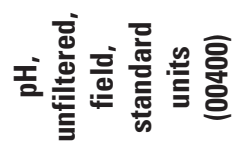

I

$1 \underset{\infty}{\infty} \infty$

$1 \prod_{\infty}^{\infty}, \infty$

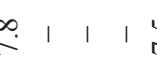

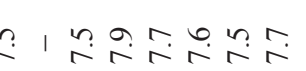

i

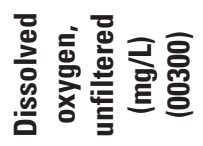

兽豆

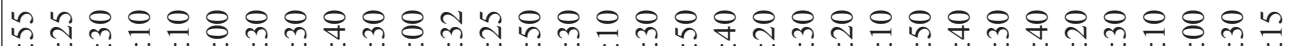

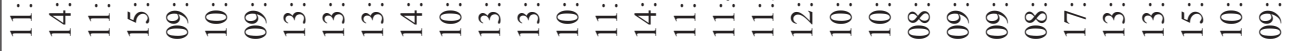
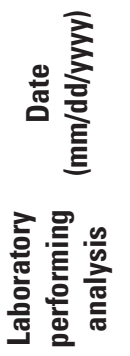

tᄒㅎㅇㅎㅇ N $\overbrace{}^{n}$ N

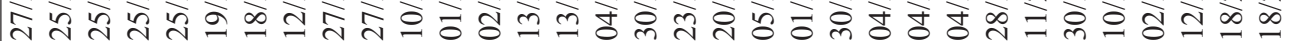

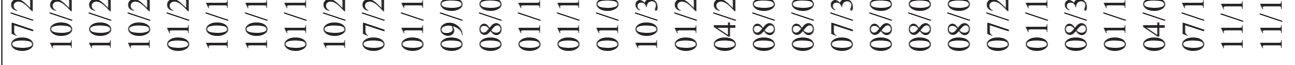

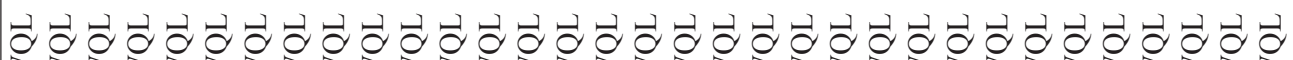

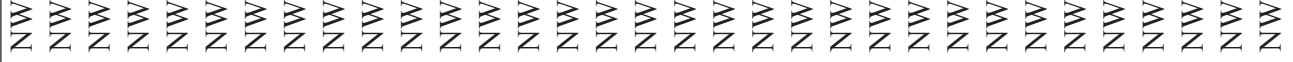

离

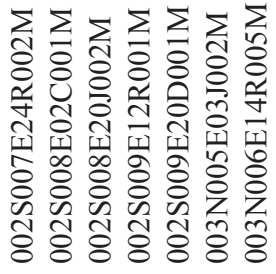

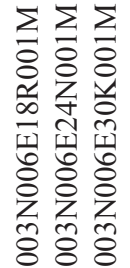




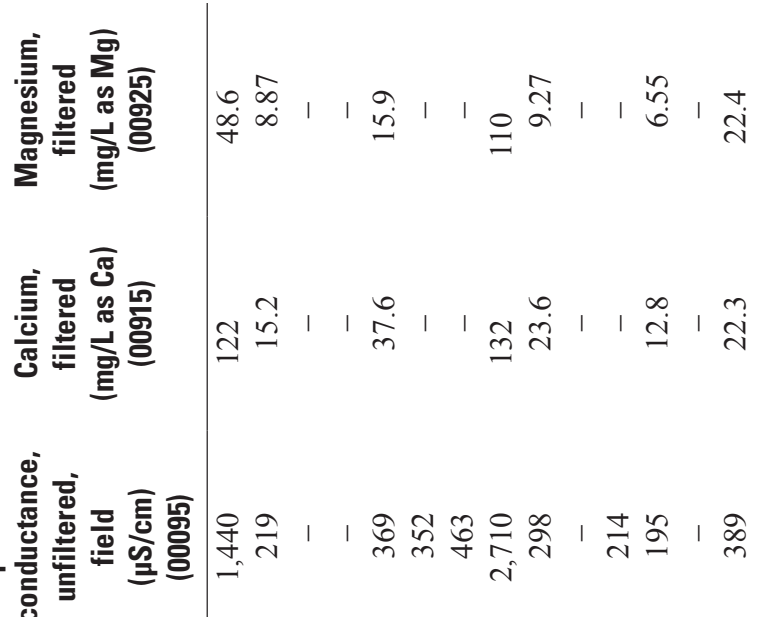




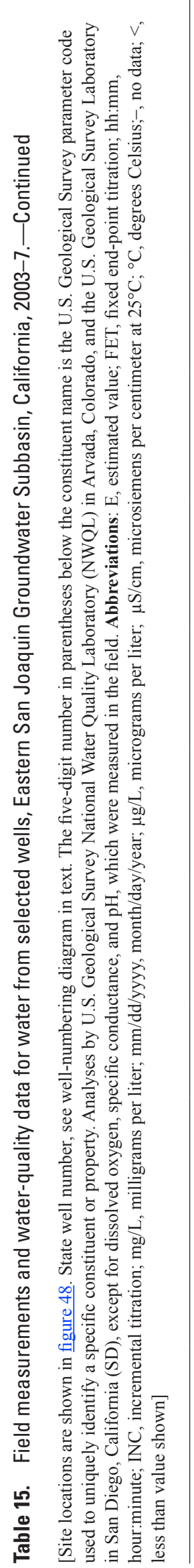

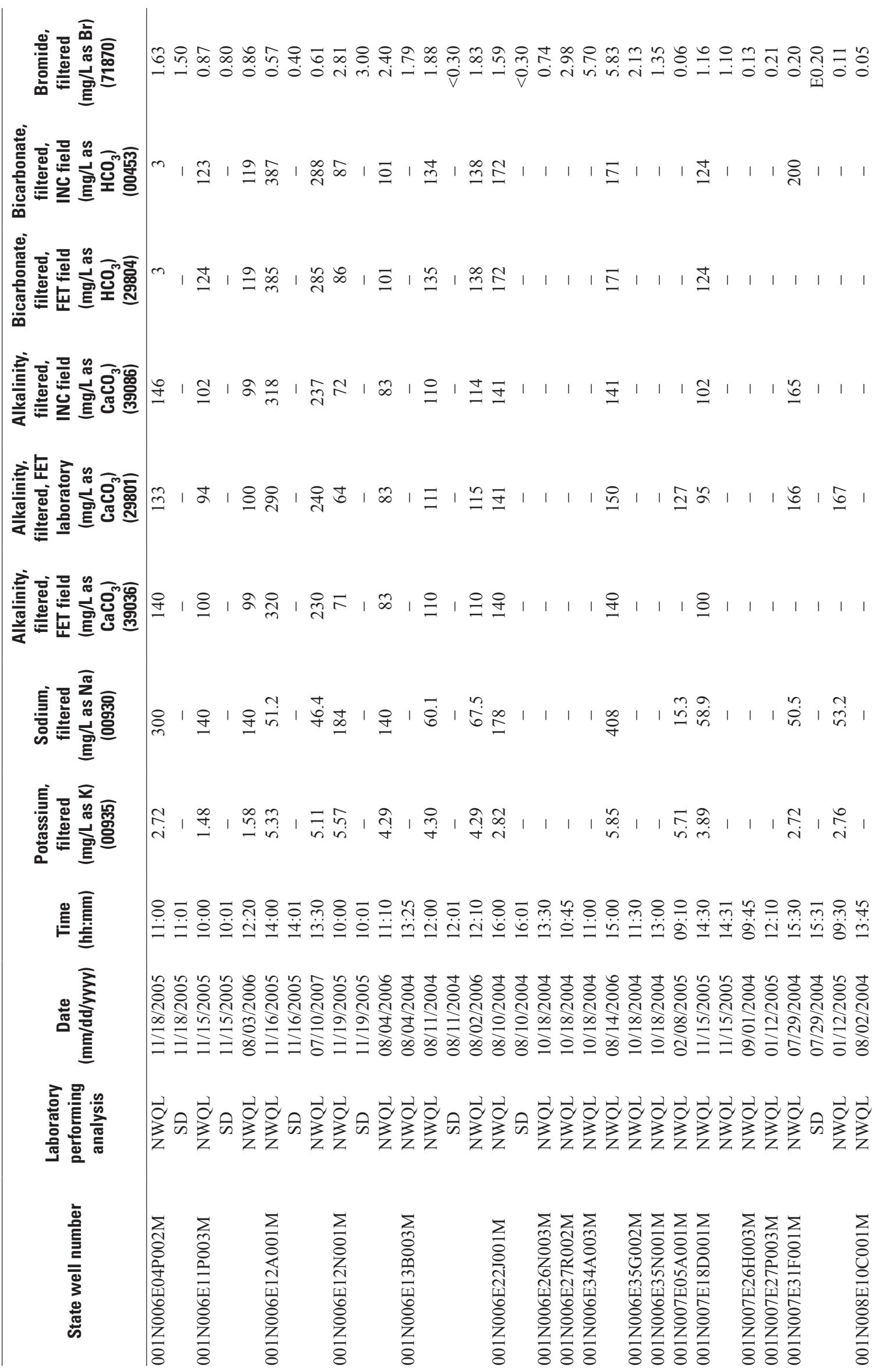




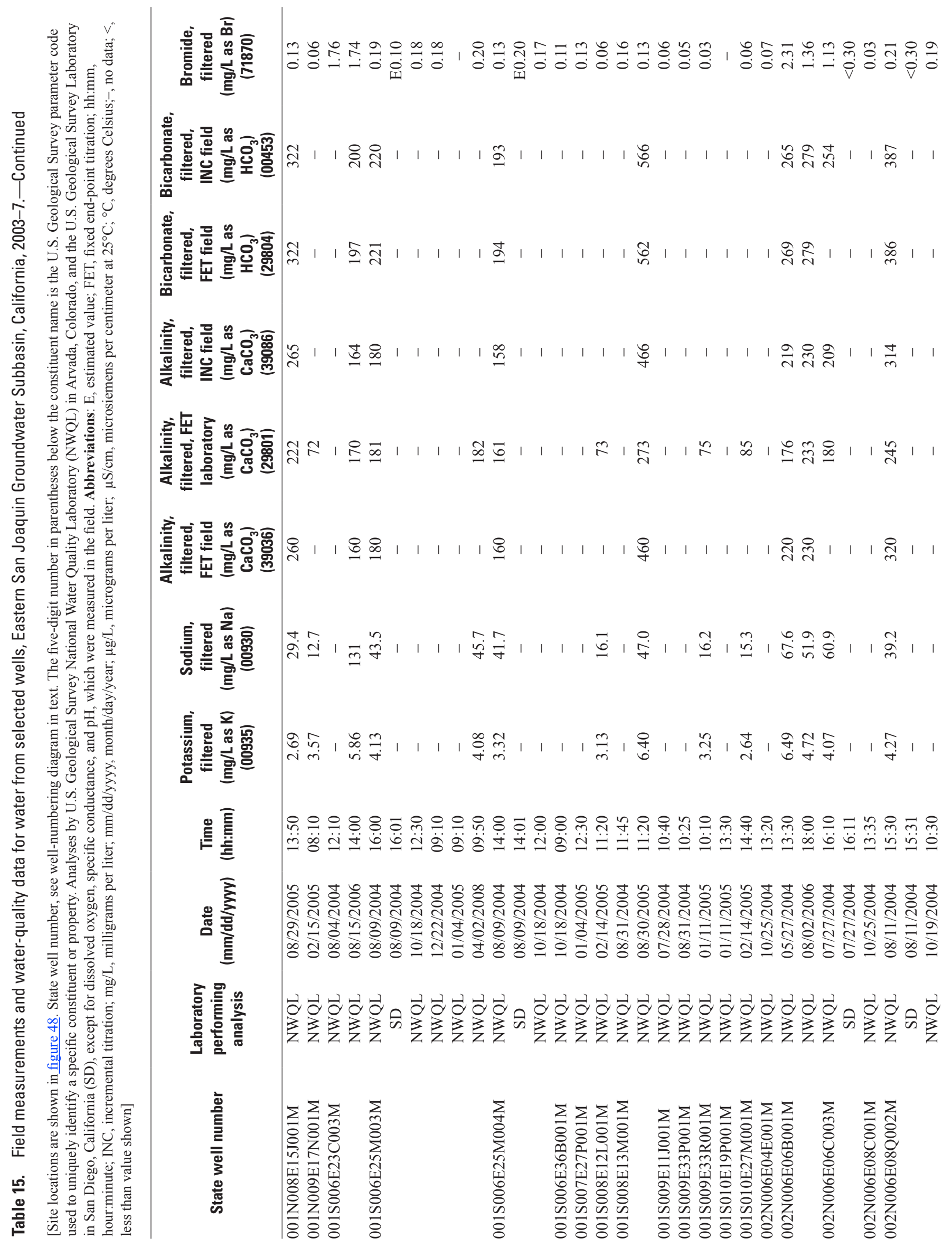



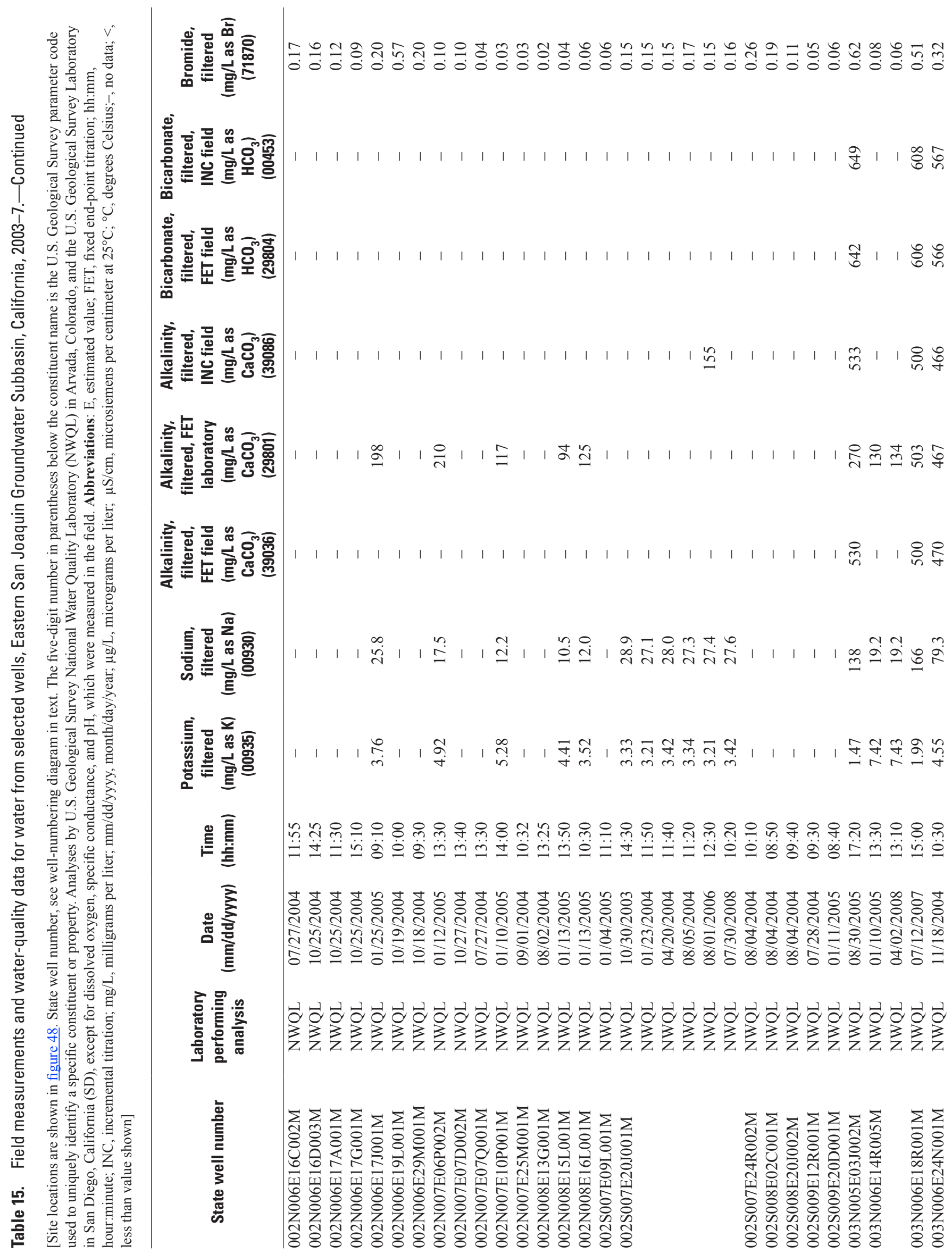


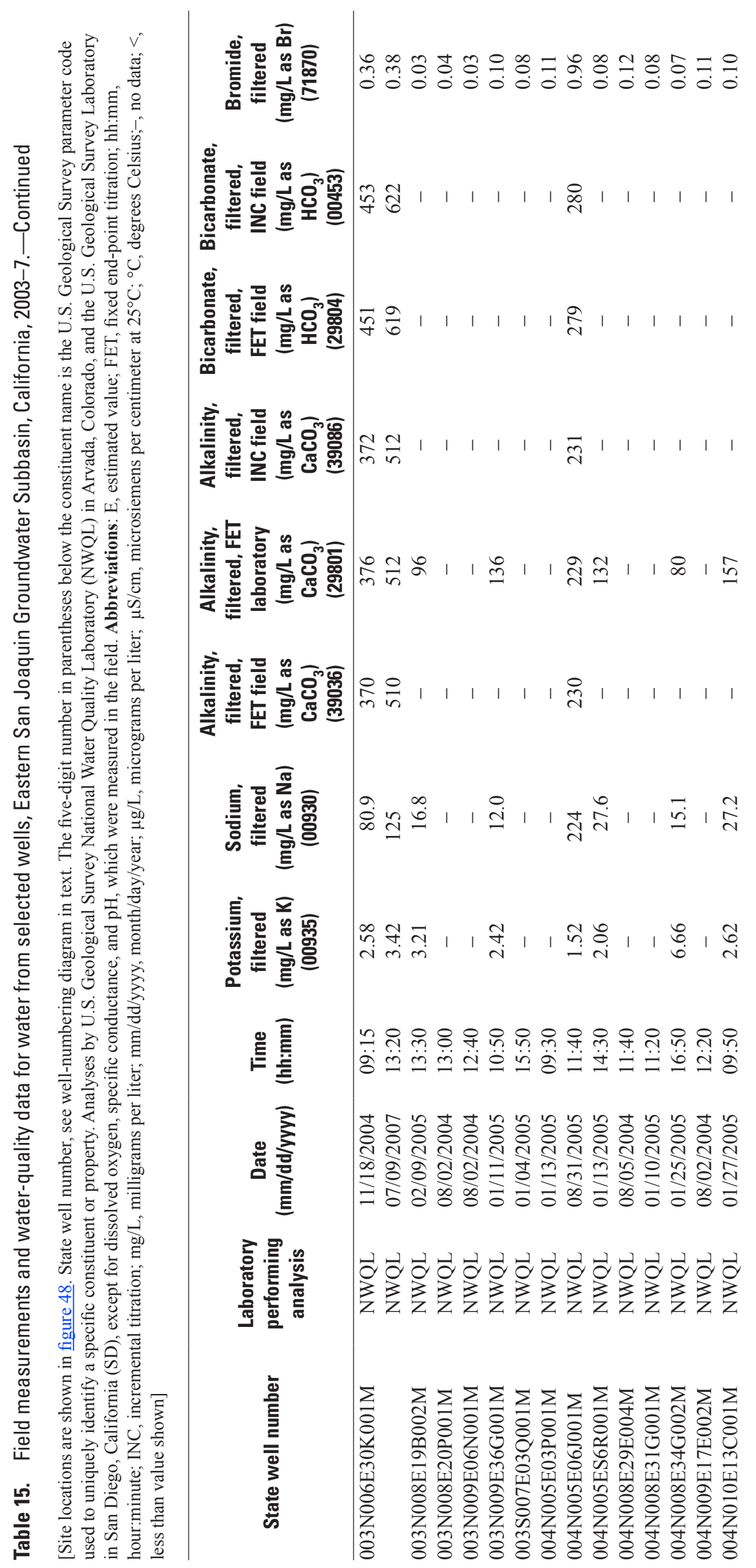




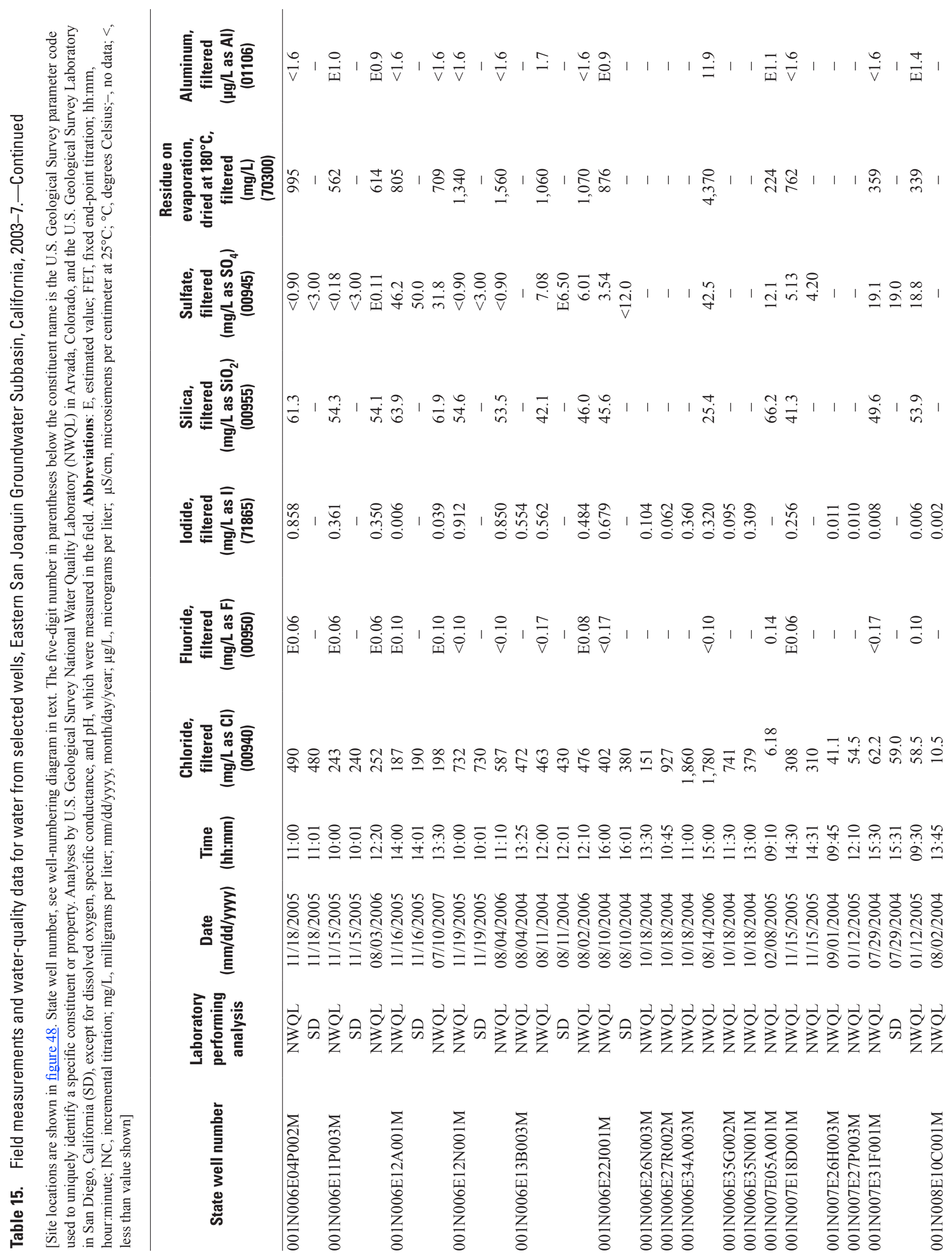



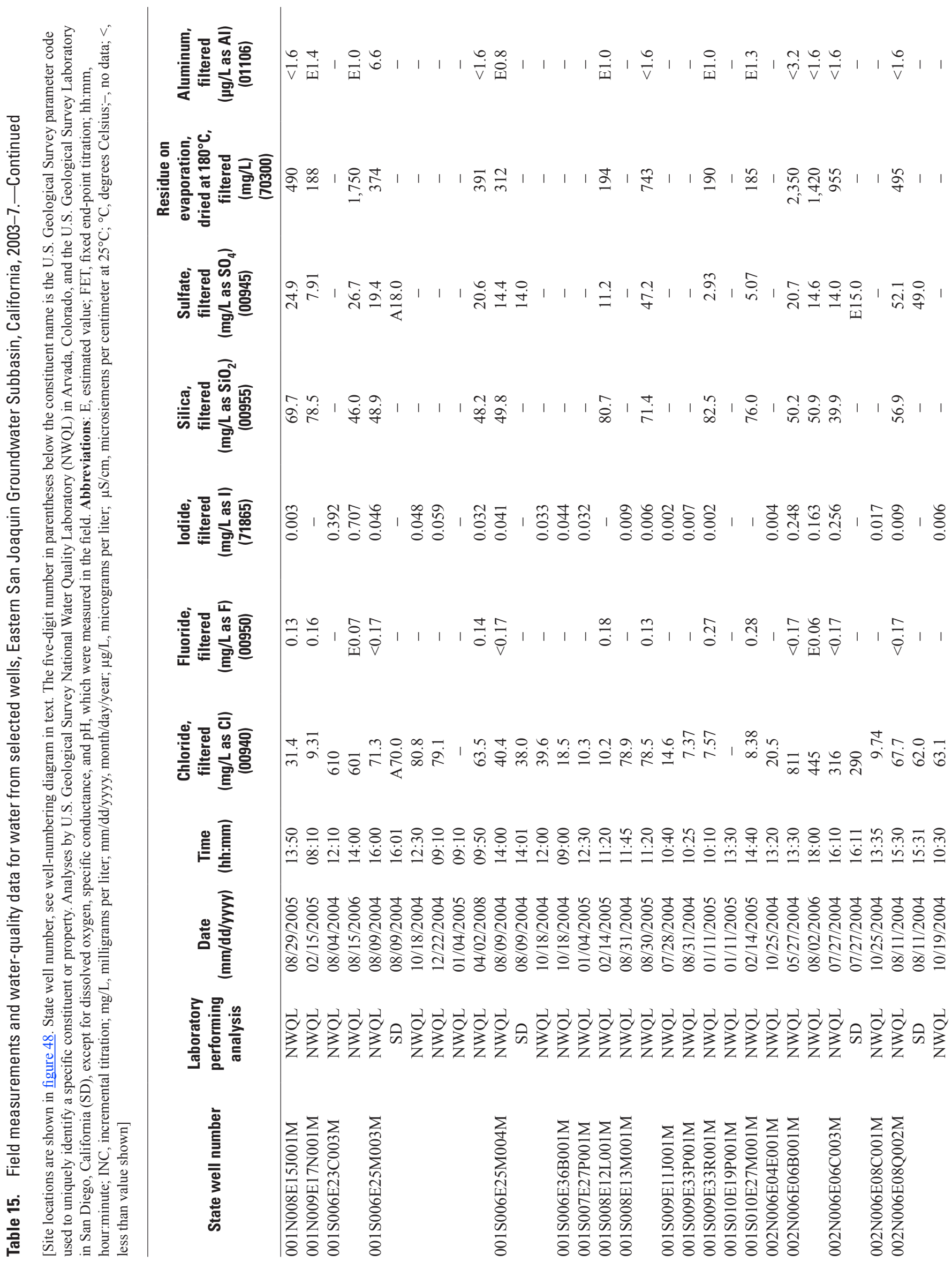


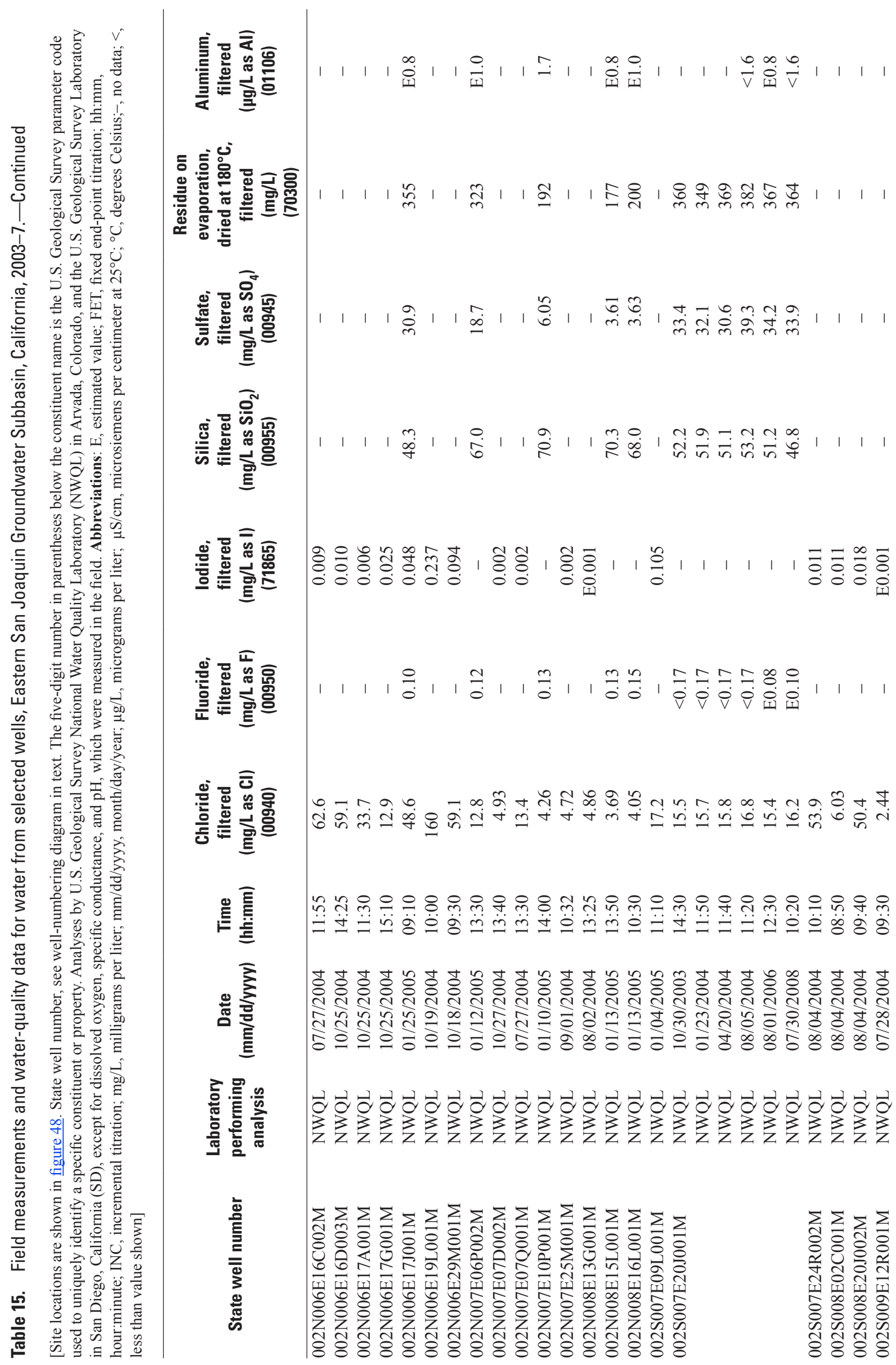




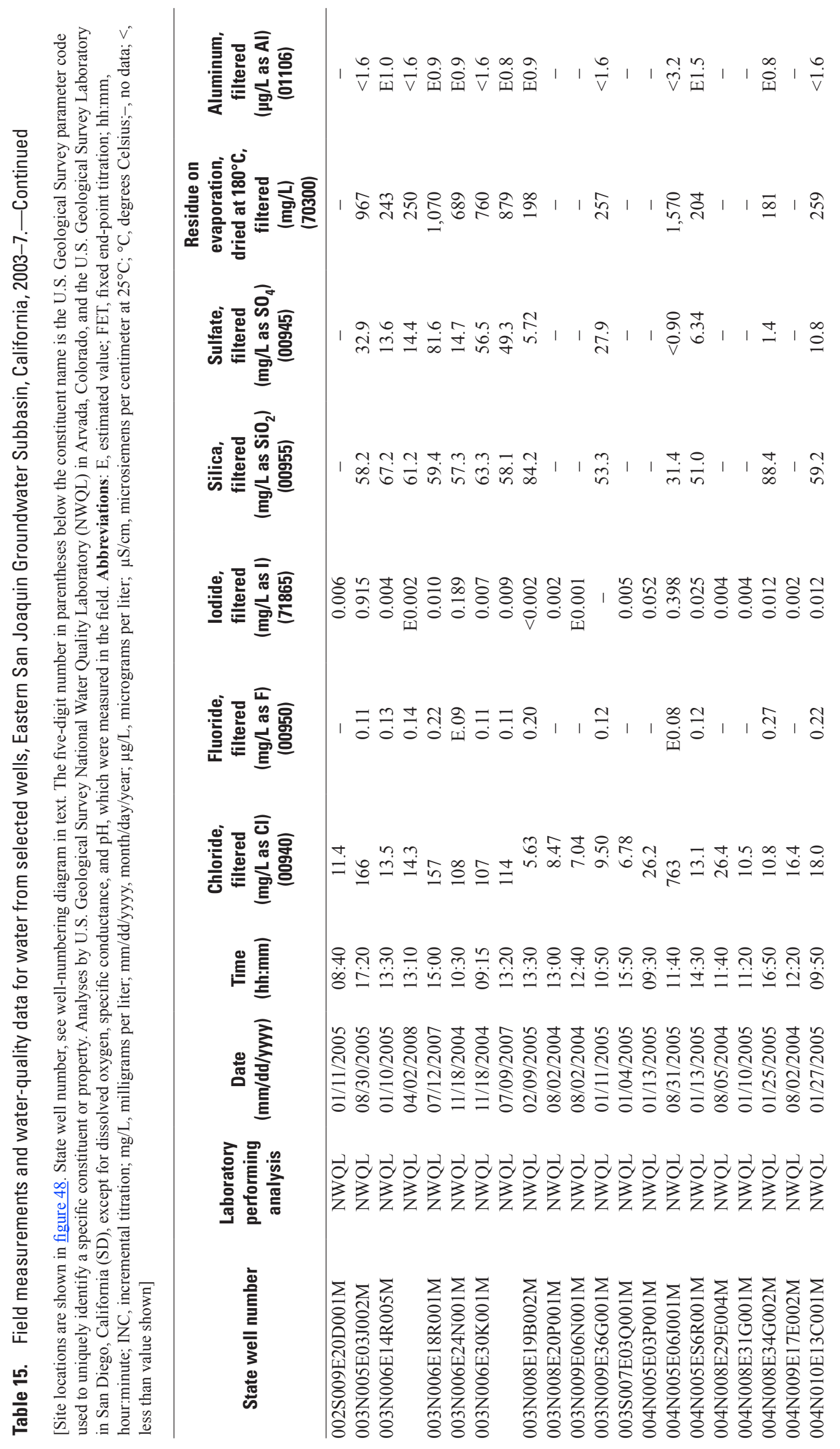




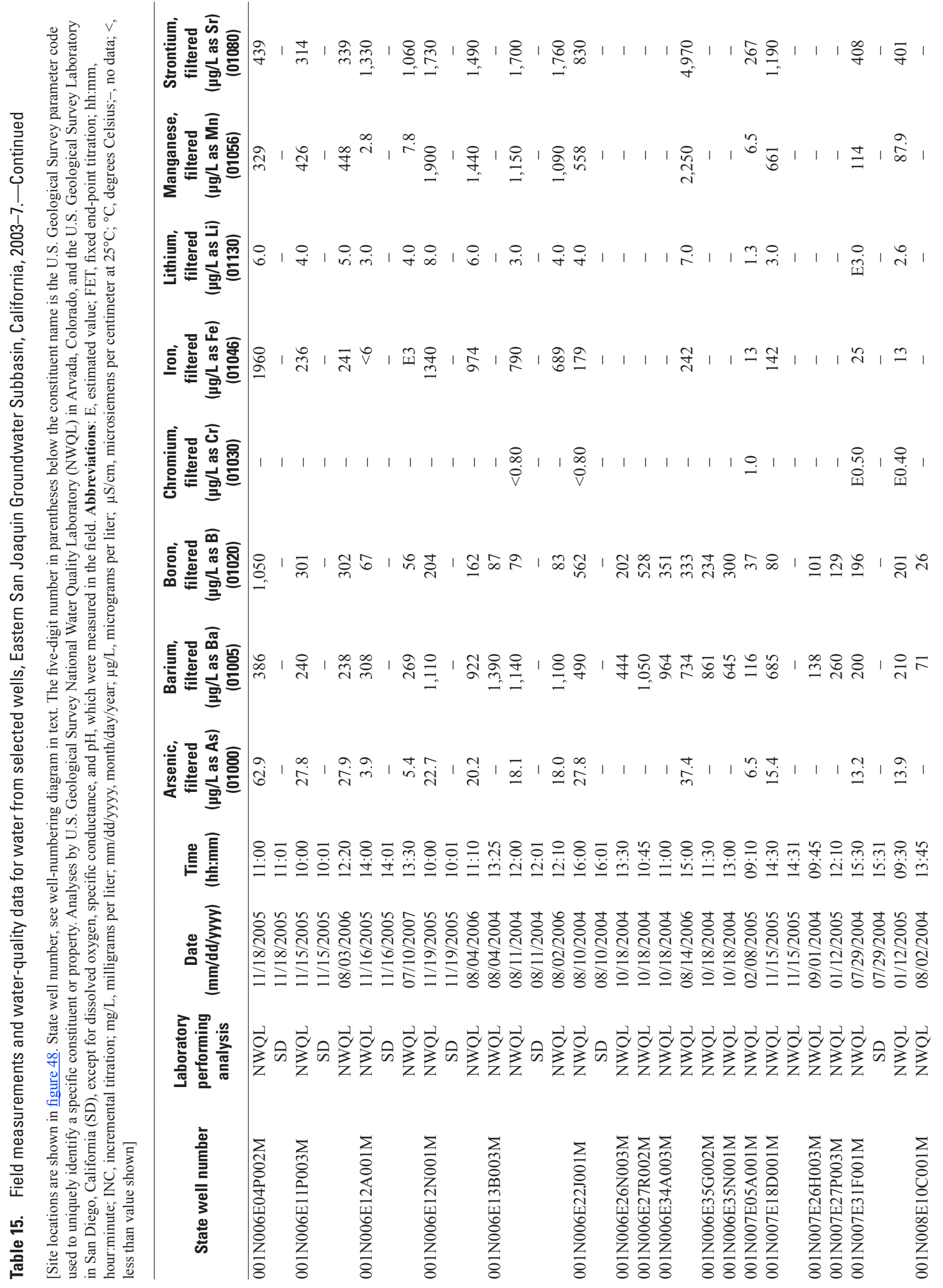




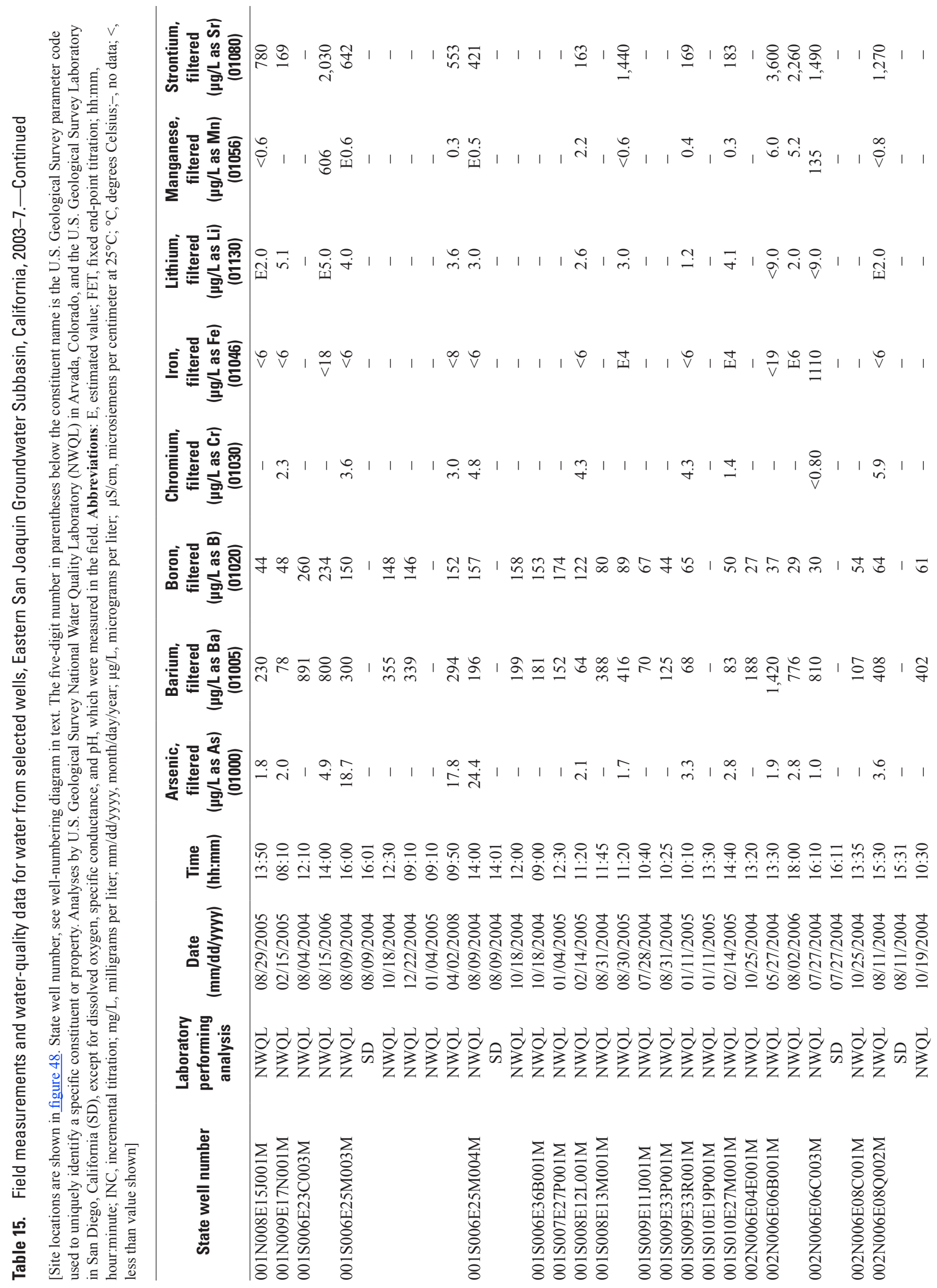




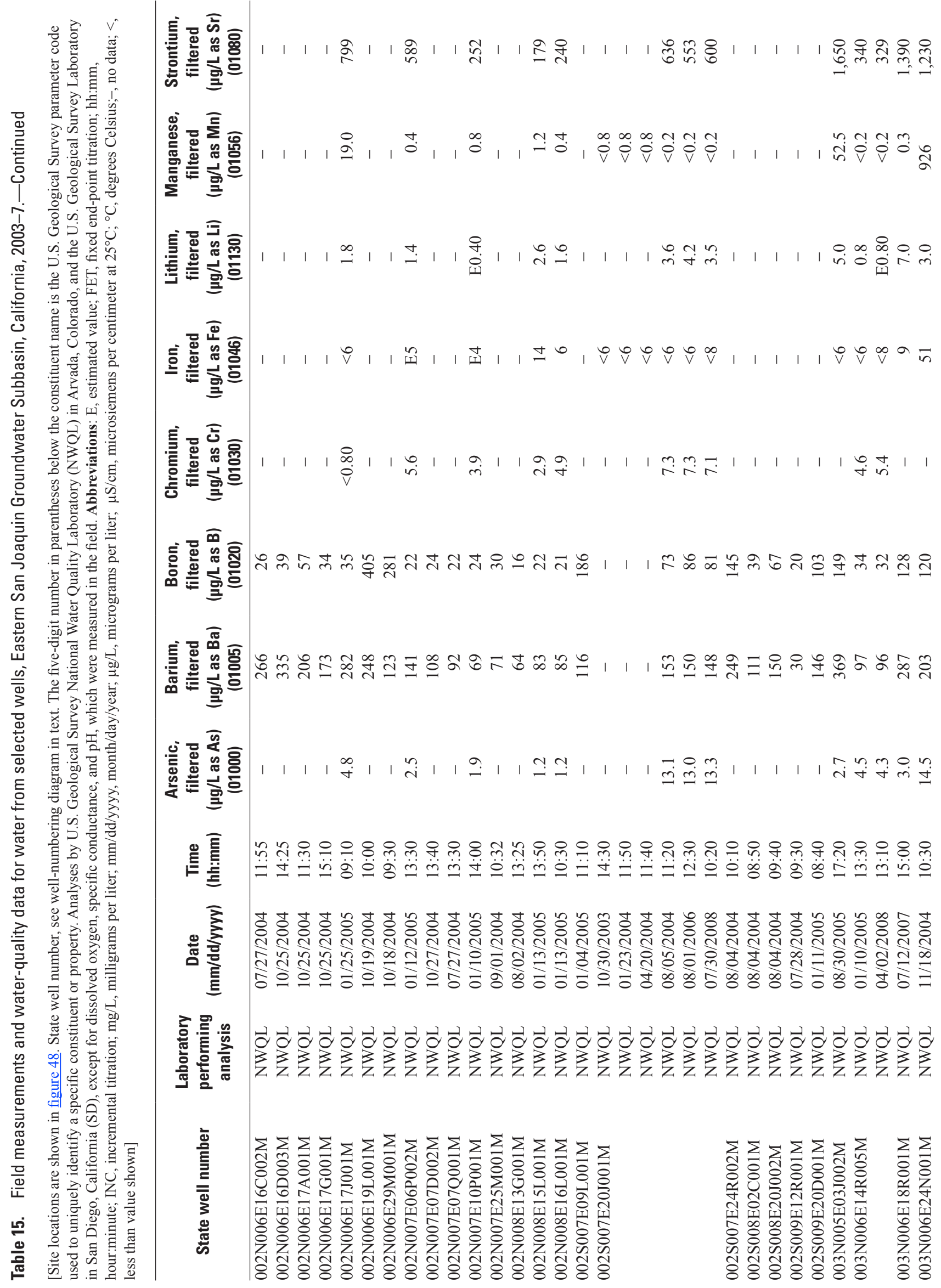




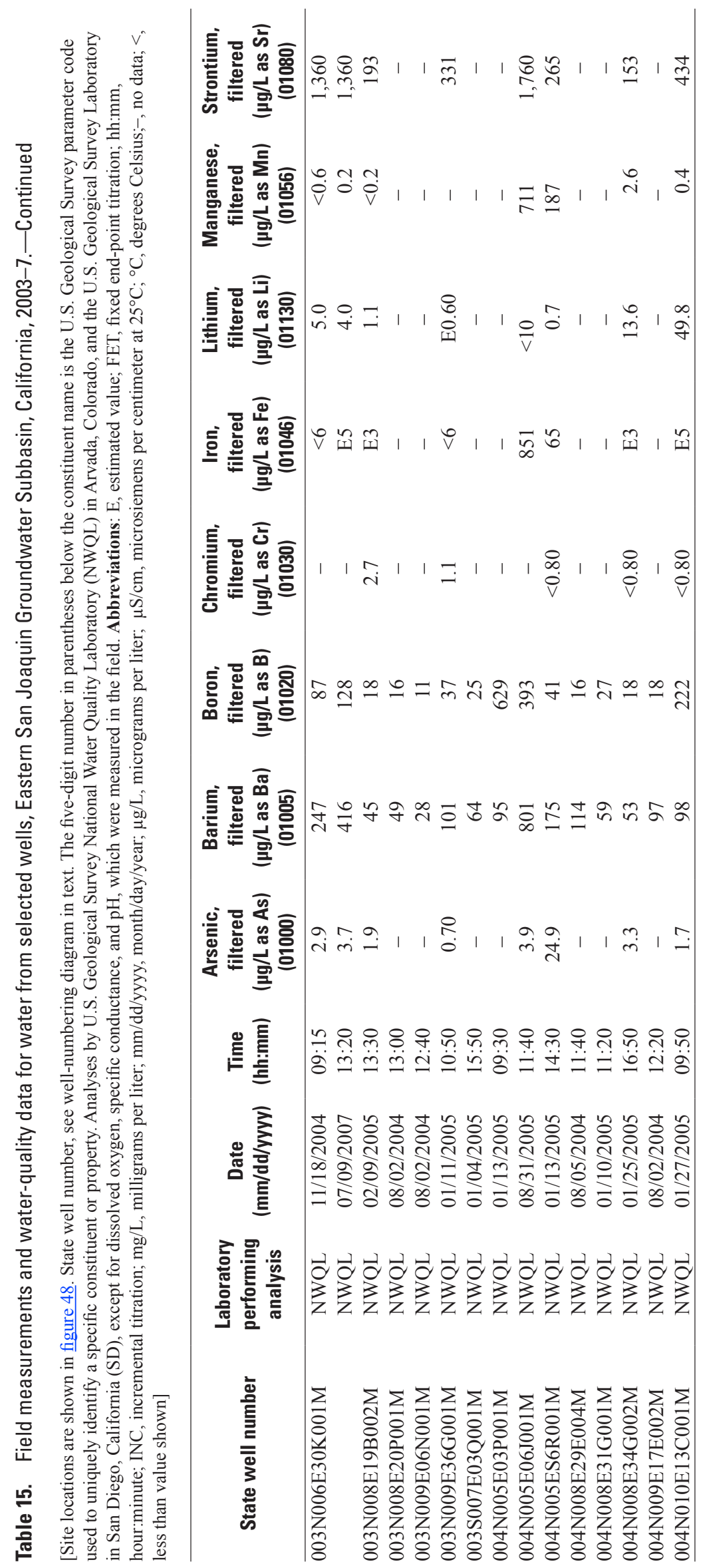


Table 16. Isotopic data for water from selected wells, Eastern San Joaquin Groundwater Subbasin, California, 2003-7.

[Site locations are shown in figure 48. State well number, see well-numbering diagram in text. The five-digit number in parentheses below the constituent name is the U.S. Geological Survey parameter code used to uniquely identify a specific constituent or property. Deuterium/protium and oxygen-18/16 analyzed by USGS National Research Program, Stable Isotope Laboratory, Reston, Virginia. Carbon age analyzed by University of Waterloo, Isotope Laboratory, Waterloo, Ontario, Canada. Tritium analyzed by University of Miami, Tritium Laboratory, Miami, Florida. Dates sites were drilled given in table 1. Abbreviations: hh:mm, hour:minute; mm/dd/yyyy, month/day/year; pCi/L, picocuries per liter; -, no data]

\begin{tabular}{|c|c|c|c|c|c|c|c|c|c|}
\hline State well number & $\begin{array}{c}\text { Date } \\
\text { (mm/dd/yyyy) }\end{array}$ & $\begin{array}{c}\text { Time } \\
\text { (hh:mm) }\end{array}$ & $\begin{array}{c}\text { Carbon-14 } \\
\text { counting } \\
\text { error, } \\
\text { filtered, } \\
\text { percent } \\
\text { modern } \\
\text { (49934) }\end{array}$ & $\begin{array}{c}\text { Carbon-14, } \\
\text { filtered, } \\
\text { percent } \\
\text { modern } \\
\text { (49933) }\end{array}$ & $\begin{array}{l}\text { Deuterium/ } \\
\text { protium } \\
\text { unfiltered, } \\
\text { per mil } \\
\text { (82082) }\end{array}$ & $\begin{array}{c}\text { Tritium, } \\
\text { unfiltered } \\
\text { (pCi/L) } \\
(07000)\end{array}$ & $\begin{array}{c}\text { Tritium } \\
\text { 2-sigma } \\
\text { combined } \\
\text { uncertainty, } \\
\text { unfiltered } \\
\text { (pCi/L) } \\
\text { (75985) }\end{array}$ & $\begin{array}{c}\text { Carbon-13/ } \\
\text { carbon-12 } \\
\text { unfiltered, } \\
\text { per mil } \\
\text { (82081) }\end{array}$ & $\begin{array}{c}\text { Oxygen-18/ } \\
\text { oxygen-16 } \\
\text { unfiltered, } \\
\text { per mil } \\
\text { (82085) }\end{array}$ \\
\hline 001N006E11P003M & $08 / 03 / 2006$ & $12: 20$ & - & - & -54.69 & - & - & - & -7.44 \\
\hline \multirow[t]{2}{*}{ 001N006E12A001M } & $11 / 16 / 2005$ & $14: 00$ & - & - & -54.00 & - & - & - & -7.43 \\
\hline & 07/10/2007 & $13: 30$ & 0.32 & 72.43 & -54.87 & 2.3 & 0.58 & -21.14 & -7.56 \\
\hline \multirow[t]{2}{*}{ 001N006E12N001M } & $11 / 19 / 2005$ & $10: 00$ & - & - & -54.60 & - & - & - & -7.43 \\
\hline & 08/04/2006 & $11: 10$ & - & - & -53.57 & - & - & - & -7.46 \\
\hline 001N006E13B003M & 08/04/2004 & $13: 25$ & - & - & -53.40 & - & - & - & -7.21 \\
\hline 001N006E26N003M & $10 / 18 / 2004$ & $13: 30$ & - & - & -66.50 & - & - & - & -8.87 \\
\hline 001N006E27R002M & $10 / 18 / 2004$ & $10: 45$ & - & - & -61.40 & - & - & - & -8.01 \\
\hline \multirow[t]{2}{*}{ 001N006E34A003M } & $10 / 18 / 2004$ & $11: 00$ & - & - & -61.00 & - & - & - & -8.06 \\
\hline & $08 / 14 / 2006$ & $15: 00$ & - & - & -61.03 & - & - & - & -7.94 \\
\hline \multirow[t]{2}{*}{ 001N006E35G002M } & $10 / 18 / 2004$ & $11: 30$ & - & - & -54.30 & - & - & - & -7.29 \\
\hline & $08 / 15 / 2006$ & $10: 00$ & - & - & -54.90 & - & - & - & -7.21 \\
\hline 001N006E35N001M & $10 / 18 / 2004$ & $13: 00$ & - & - & -62.20 & - & - & - & -8.38 \\
\hline 001N007E05A001M & $02 / 08 / 2005$ & 09:10 & - & - & -56.40 & 16.3 & 1.30 & - & -7.59 \\
\hline 001N007E18D001M & $11 / 15 / 2005$ & $14: 30$ & - & - & -52.30 & - & - & - & -7.16 \\
\hline 001N007E26H003M & 09/01/2004 & $09: 45$ & - & - & -49.30 & - & - & - & -6.65 \\
\hline 001N007E27P003M & $01 / 12 / 2005$ & $12: 10$ & - & - & -49.50 & 3.5 & 0.60 & - & -6.70 \\
\hline \multirow{3}{*}{ 001S006E25M003M } & $10 / 18 / 2004$ & $12: 30$ & - & - & -67.40 & - & - & - & -9.32 \\
\hline & $01 / 04 / 2005$ & 09:10 & - & - & -67.60 & 20.5 & 1.30 & - & -9.31 \\
\hline & $04 / 02 / 2008$ & $09: 50$ & 0.36 & 74.56 & -63.20 & - & - & -15.67 & -8.42 \\
\hline \multirow[t]{2}{*}{ 001S006E25M004M } & 08/09/2004 & $14: 00$ & - & - & -61.40 & 15.0 & 0.96 & - & -8.27 \\
\hline & $10 / 18 / 2004$ & $12: 00$ & - & - & -61.50 & - & - & - & -8.37 \\
\hline 001S006E36B001M & $10 / 18 / 2004$ & 09:00 & - & - & -60.60 & - & - & - & -8.37 \\
\hline 001S007E27P001M & $01 / 04 / 2005$ & $12: 30$ & - & - & -60.30 & 12.2 & 1.00 & - & -8.15 \\
\hline 001S008E12L001M & $02 / 14 / 2005$ & $11: 20$ & - & - & -49.90 & - & 0.60 & - & -6.63 \\
\hline \multirow[t]{2}{*}{ 001S008E13M001M } & $08 / 31 / 2004$ & $11: 45$ & - & - & -50.60 & - & - & - & -6.85 \\
\hline & $08 / 30 / 2005$ & $11: 20$ & - & - & -52.60 & - & - & - & -6.91 \\
\hline 001S009E11J001M & $07 / 28 / 2004$ & $10: 40$ & - & - & -50.40 & - & - & - & -6.58 \\
\hline 001S009E33P001M & $08 / 31 / 2004$ & $10: 25$ & - & - & -67.00 & - & - & - & -9.08 \\
\hline 001S009E33R001M & $01 / 11 / 2005$ & $10: 10$ & - & - & -52.70 & 1.0 & 0.60 & - & -7.40 \\
\hline 001S010E19P001M & $01 / 11 / 2005$ & $13: 30$ & - & - & -77.50 & 37.4 & 1.90 & - & -10.60 \\
\hline 001S010E27M001M & $02 / 14 / 2005$ & $14: 40$ & - & - & -65.60 & 3.2 & 0.60 & - & -8.90 \\
\hline
\end{tabular}


Table 16. Isotopic data for water from selected wells, Eastern San Joaquin Groundwater Subbasin, California, 2003-7.

-Continued

[Site locations are shown in figure 48. State well number, see well-numbering diagram in text. The five-digit number in parentheses below the constituent name is the U.S. Geological Survey parameter code used to uniquely identify a specific constituent or property. Deuterium/protium and oxygen-18/16 analyzed by USGS National Research Program, Stable Isotope Laboratory, Reston, Virginia. Carbon age analyzed by University of Waterloo, Isotope Laboratory, Waterloo, Ontario, Canada. Tritium analyzed by University of Miami, Tritium Laboratory, Miami, Florida. Dates sites were drilled given in table 1. Abbreviations: hh:mm, hour:minute; mm/dd/yyyy, month/day/year; $\mathrm{pCi} / \mathrm{L}$, picocuries per liter; -, no data]

\begin{tabular}{|c|c|c|c|c|c|c|c|c|c|}
\hline State well number & $\begin{array}{c}\text { Date } \\
\text { (mm/dd/yyyy) }\end{array}$ & $\begin{array}{c}\text { Time } \\
\text { (hh:mm) }\end{array}$ & $\begin{array}{c}\text { Carbon-14 } \\
\text { counting } \\
\text { error, } \\
\text { filtered, } \\
\text { percent } \\
\text { modern } \\
\text { (49934) }\end{array}$ & $\begin{array}{c}\text { Carbon-14, } \\
\text { filtered, } \\
\text { percent } \\
\text { modern } \\
\text { (49933) }\end{array}$ & $\begin{array}{l}\text { Deuterium/ } \\
\text { protium } \\
\text { unfiltered, } \\
\text { per mil } \\
\text { (82082) }\end{array}$ & $\begin{array}{c}\text { Tritium, } \\
\text { unfiltered } \\
\text { (pCi/L) } \\
(07000)\end{array}$ & $\begin{array}{c}\text { Tritium } \\
\text { 2-sigma } \\
\text { combined } \\
\text { uncertainty, } \\
\text { unfiltered } \\
\text { (pCi/L) } \\
(75985)\end{array}$ & $\begin{array}{c}\text { Carbon-13/ } \\
\text { carbon-12 } \\
\text { unfiltered, } \\
\text { per mil } \\
\text { (82081) }\end{array}$ & $\begin{array}{c}\text { 0xygen-18/ } \\
\text { oxygen-16 } \\
\text { unfiltered, } \\
\text { per mil } \\
(82085)\end{array}$ \\
\hline 002N006E06B001M & $08 / 02 / 2006$ & $18: 00$ & - & - & -55.70 & - & - & - & -6.98 \\
\hline 002N006E06C003M & $07 / 27 / 2004$ & $16: 10$ & 0.87 & 85.88 & -54.10 & 11.8 & 0.77 & -18.67 & -6.29 \\
\hline 002N006E08C001M & $10 / 25 / 2004$ & $13: 35$ & - & - & -67.90 & - & - & - & -8.95 \\
\hline \multirow[t]{2}{*}{ 002N006E08Q002M } & $08 / 11 / 2004$ & $15: 30$ & - & - & -55.30 & 11.9 & 0.77 & - & -7.64 \\
\hline & $10 / 19 / 2004$ & $10: 30$ & - & - & -54.10 & - & - & - & -7.67 \\
\hline 002N006E16C002M & $07 / 27 / 2004$ & $11: 55$ & - & - & -60.30 & - & - & - & -8.19 \\
\hline 002N006E17J001M & $01 / 25 / 2005$ & 09:10 & - & - & -58.80 & 3.8 & 1.00 & - & -8.08 \\
\hline 002N006E19L001M & $10 / 19 / 2004$ & $10: 00$ & - & - & -54.10 & - & - & - & -6.95 \\
\hline 002N006E29M001M & $10 / 18 / 2004$ & 09:30 & - & - & -60.20 & - & - & - & -8.26 \\
\hline 002N007E06P002M & $01 / 12 / 2005$ & $13: 30$ & - & - & -68.80 & 33.9 & 1.90 & - & -9.51 \\
\hline 002N007E07D002M & $10 / 27 / 2004$ & $13: 40$ & - & - & -74.30 & - & - & - & -10.38 \\
\hline 002N007E07Q001M & $07 / 27 / 2004$ & $13: 30$ & - & - & -64.20 & - & - & - & -8.88 \\
\hline 002N007E10P001M & $01 / 10 / 2005$ & $14: 00$ & 0.37 & 71.46 & -60.60 & 0.3 & 0.60 & -16.49 & -8.70 \\
\hline 002N007E25M001M & $09 / 01 / 2004$ & $10: 32$ & - & - & -59.00 & - & - & - & -8.22 \\
\hline 002N008E13G001M & $08 / 02 / 2004$ & $13: 25$ & - & - & -57.10 & - & - & - & -7.87 \\
\hline 002N008E15L001M & $01 / 13 / 2005$ & $13: 50$ & - & - & -59.20 & 0.3 & 0.60 & - & -8.44 \\
\hline 002N008E16L001M & $01 / 13 / 2005$ & $10: 30$ & 0.59 & 91.68 & -60.50 & - & 0.60 & -17.51 & -8.58 \\
\hline 003N006E14R005M & $04 / 02 / 2008$ & $13: 10$ & 0.38 & 80.44 & -65.80 & 4.5 & - & -15.20 & -8.94 \\
\hline 003N006E18R001M & $07 / 12 / 2007$ & $15: 00$ & 0.44 & 113.30 & -56.19 & 6.1 & 0.58 & -14.49 & -7.73 \\
\hline 003N006E24N001M & $11 / 18 / 2004$ & $10: 30$ & - & - & -60.70 & - & - & - & -8.02 \\
\hline \multirow[t]{2}{*}{ 003N006E30K001M } & $11 / 18 / 2004$ & $09: 15$ & - & - & -55.90 & - & - & - & -7.76 \\
\hline & 07/09/2007 & $13: 20$ & 0.44 & 110.30 & -56.66 & 8.0 & 0.58 & -14.78 & -7.70 \\
\hline 003N008E19B002M & $02 / 09 / 2005$ & $13: 30$ & - & - & -57.80 & -0.3 & 1.00 & - & -8.05 \\
\hline 003N008E20P001M & $08 / 02 / 2004$ & $13: 00$ & - & - & -56.20 & - & - & - & -7.75 \\
\hline 003N009E06N001M & $08 / 02 / 2004$ & $12: 40$ & - & - & -49.80 & - & - & - & -6.32 \\
\hline 003N009E36G001M & $01 / 11 / 2005$ & $10: 50$ & 0.52 & 116.70 & -54.40 & 14.1 & 1.00 & -15.73 & -7.55 \\
\hline 003S007E03Q001M & $01 / 04 / 2005$ & $15: 50$ & - & - & -81.10 & 14.1 & 1.00 & - & -11.21 \\
\hline 004N005E03P001M & $01 / 13 / 2005$ & 09:30 & - & - & -74.60 & 1.6 & 0.60 & - & -10.13 \\
\hline 004N005E06J001M & $08 / 31 / 2005$ & $11: 40$ & - & - & -71.20 & - & - & - & -9.79 \\
\hline 004N005ES6R001M & $01 / 13 / 2005$ & $14: 30$ & - & - & -69.60 & 1.3 & 0.60 & - & -9.36 \\
\hline
\end{tabular}


Table 16. Isotopic data for water from selected wells, Eastern San Joaquin Groundwater Subbasin, California, 2003-7. -Continued

[Site locations are shown in figure 48. State well number, see well-numbering diagram in text. The five-digit number in parentheses below the constituent name is the U.S. Geological Survey parameter code used to uniquely identify a specific constituent or property. Deuterium/protium and oxygen-18/16 analyzed by USGS National Research Program, Stable Isotope Laboratory, Reston, Virginia. Carbon age analyzed by University of Waterloo, Isotope Laboratory, Waterloo, Ontario, Canada. Tritium analyzed by University of Miami, Tritium Laboratory, Miami, Florida. Dates sites were drilled given in table 1. Abbreviations: hh:mm, hour:minute; mm/dd/yyyy, month/day/year; pCi/L, picocuries per liter; -, no data]

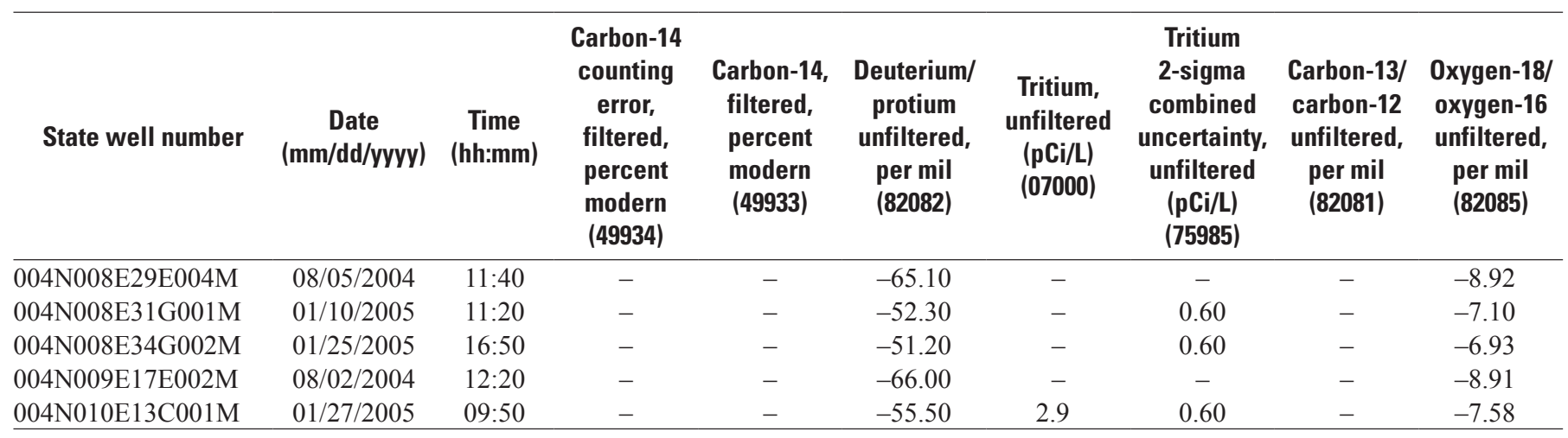


Table 17. Sampling-well sites, Eastern San Joaquin Groundwater Subbasin, California

[State well number, see well-numbering diagram in text. Site locations are shown in figure 48. Abbreviations: ft, feet; LSD, land surface datum; NAVD 88, North American Vertical Datum of 1988; USGS ID, U.S. Geological Survey identification number: the unique number for each site in USGS National Water Information System (NWIS) database; -, no data]

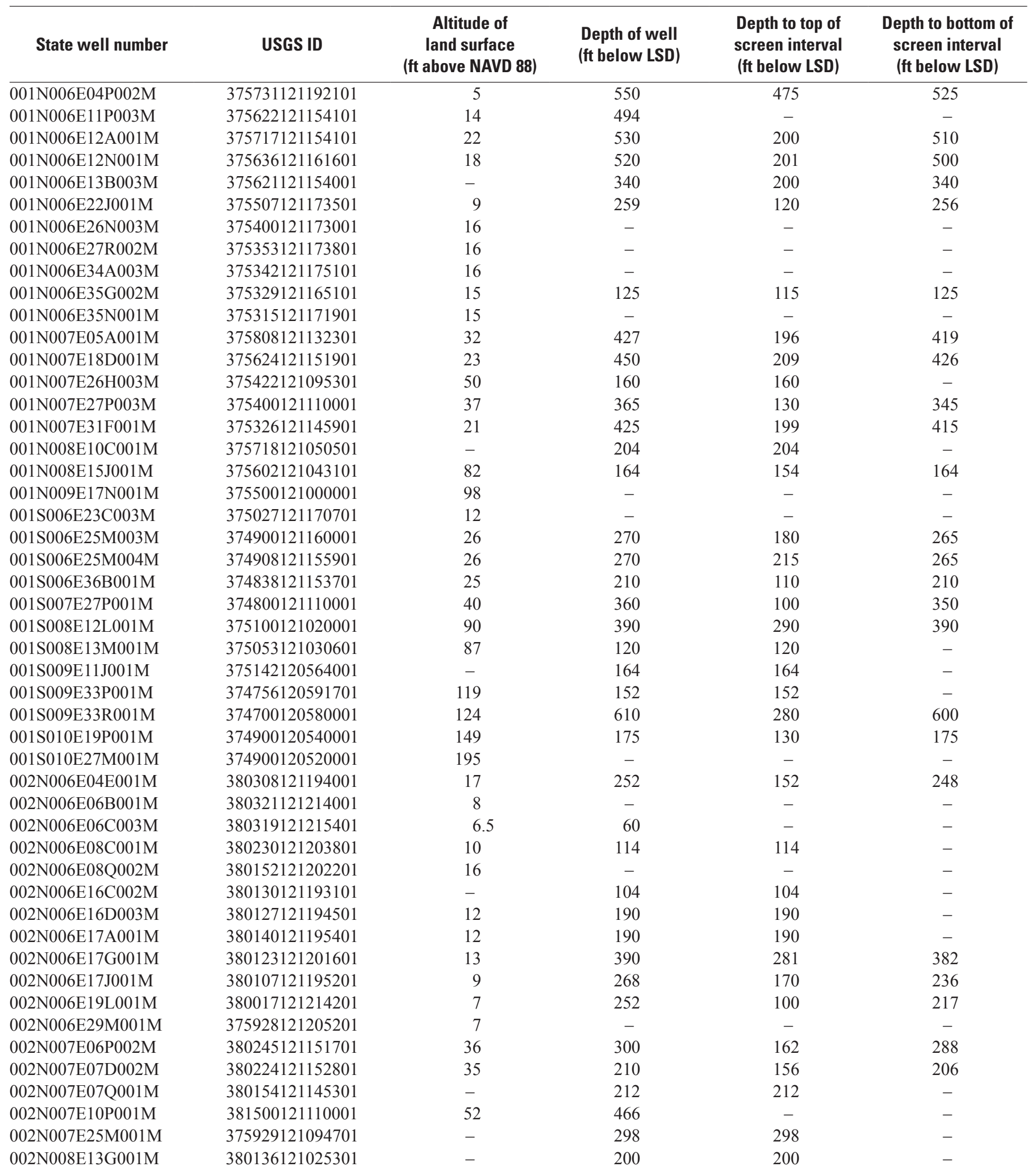


Table 17. Sampling-well sites, Eastern San Joaquin Groundwater Subbasin, California.—Continued

[State well number, see well-numbering diagram in text. Site locations are shown in figure 48. Abbreviations: ft, feet; LSD, land surface datum; NAVD 88, North American Vertical Datum of 1988; USGS ID, U.S. Geological Survey identification number: the unique number for each site in USGS National Water Information System (NWIS) database; -, no data]

\begin{tabular}{|c|c|c|c|c|c|}
\hline State well number & USGS ID & $\begin{array}{c}\text { Altitude of } \\
\text { land surface } \\
\text { (ft above NAVD 88) }\end{array}$ & $\begin{array}{l}\text { Depth of well } \\
\text { (ft below LSD) }\end{array}$ & $\begin{array}{l}\text { Depth to top of } \\
\text { screen interval } \\
\text { (ft below LSD) }\end{array}$ & $\begin{array}{l}\text { Depth to bottom of } \\
\text { screen interval } \\
\text { (ft below LSD) }\end{array}$ \\
\hline$\overline{002 \mathrm{~N} 008 \mathrm{E} 15 \mathrm{~L} 001 \mathrm{M}}$ & 380118121052001 & 87 & 619 & - & - \\
\hline 002N008E16L001M & 380113121062801 & 80 & 270 & 190 & 270 \\
\hline 002S007E09L001M & 374600121120001 & 37 & 350 & 138 & 340 \\
\hline 002S007E20J001M & 374448121130701 & 34 & 175 & 155 & 175 \\
\hline 002S007E24R002M & 374424121083301 & 56 & 98 & 98 & - \\
\hline 002S008E02C001M & 374749121035001 & - & 76 & 76 & - \\
\hline 002S008E20J002M & 374444121062201 & - & 140 & 182 & 310 \\
\hline 002S009E12R001M & 374610120552801 & - & 280 & 280 & - \\
\hline 002S009E20D001M & 374500121000001 & 73 & - & - & - \\
\hline 003N005E03J002M & 380815121243001 & 7 & - & - & - \\
\hline 003N006E14R005M & 380606121164501 & 38 & 403 & 200 & 395 \\
\hline 003N006E18R001M & 380610121211001 & 19 & 120 & - & - \\
\hline 003N006E24N001M & 380518121230201 & 8 & - & - & - \\
\hline 003N006E30K001M & 380446121213001 & 12 & 53 & - & - \\
\hline 003N008E19B002M & 380608121081801 & 88 & 164 & - & - \\
\hline 003N008E20P001M & 380531121073001 & 90 & 184 & 184 & - \\
\hline 003N009E06N001M & 380808121015801 & - & 334 & 344 & - \\
\hline 003N009E36G001M & 380419120555101 & 170 & - & - & - \\
\hline 003S007E03Q001M & 374100121110001 & 40 & - & - & - \\
\hline 004N005E03P001M & 381300121250001 & 10 & 245 & 135 & - \\
\hline 004N005E06J001M & 381332121280501 & 4 & 120 & - & - \\
\hline 004N005E06R001M & 380800121220001 & 18 & 212 & - & - \\
\hline 004N008E29E004M & 381018121075501 & 95 & 216 & 216 & - \\
\hline 004N008E31G001M & 380918121081301 & 100 & 535 & - & - \\
\hline 004N008E34G002M & 380925121045501 & 190 & 208 & - & - \\
\hline 004N009E17E002M & 381210121010201 & 185 & 156 & 156 & - \\
\hline 004N010E13C001M & 381200120490001 & 720 & 310 & 100 & 310 \\
\hline
\end{tabular}




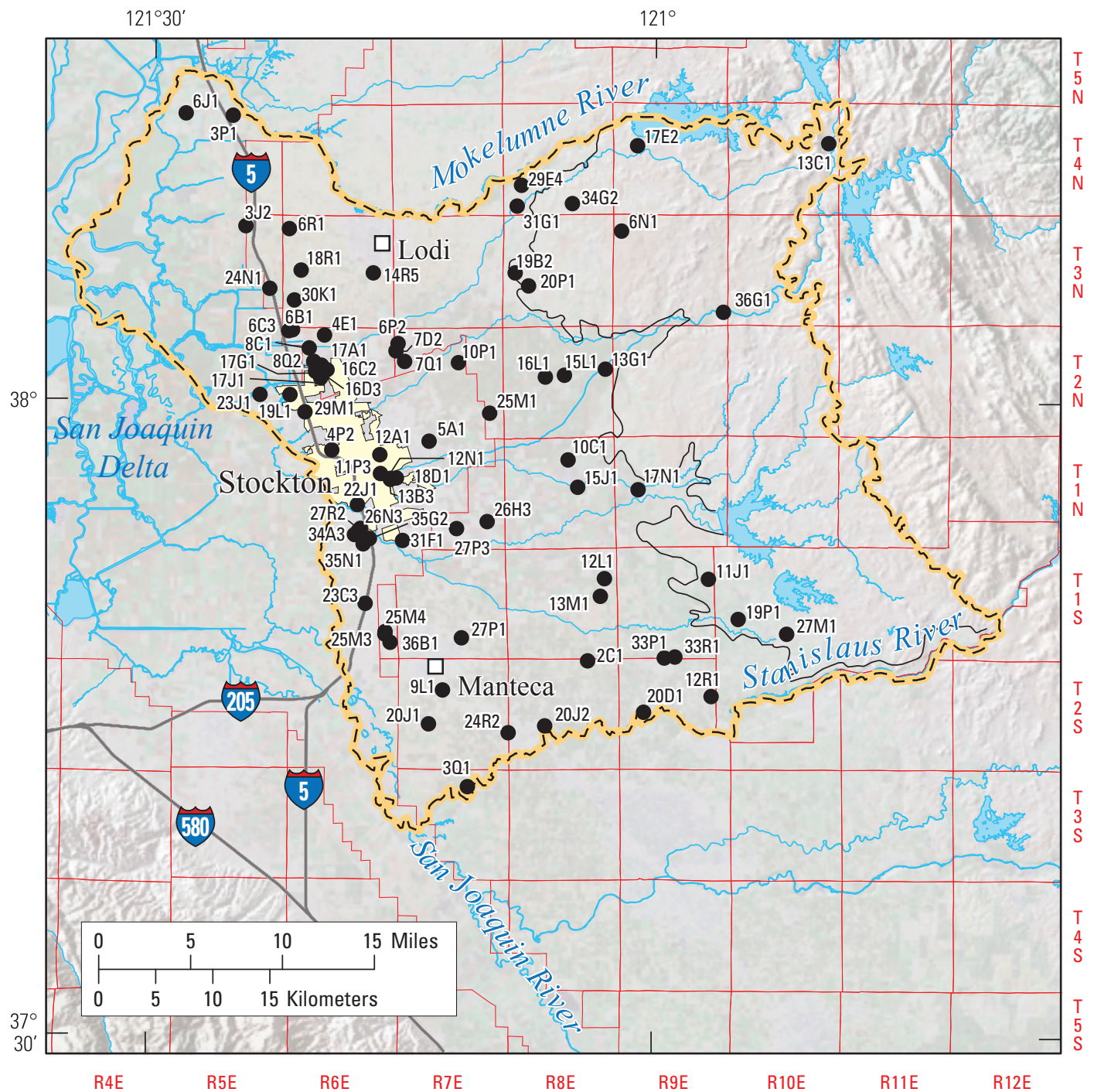

Figure 48. Location of the study area and public-supply and private well sampling sites, Eastern San Joaquin Groundwater Subbasin, California.

\section{EXPLANATION}

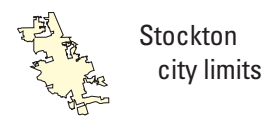

Eastern San Joaquin

Groundwater

Subbasin

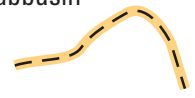

Consolidated to partly consolidated rock boundary

6N1 Well site and well number 


\section{Depth-Dependent Samples}

Depth-dependent sampling allows for sampling of well at certain discrete sampling intervals instead of sampling a bulk sample from the whole well screen interval. A small-diameter, commercially available, gas-displacement pump was used to collect samples within selected wells under pumping conditions (Izbicki, 2004; fig. 49). The sample pump consists of a series of one-way flow valves connected to the surface by two 0.3 -cm-diameter Teflon tubes bonded together into a single hose (fig. 50). One tube serves as a pressure line, and the other serves as the sample line. The pump, hose, and weights are less than 1 inch in diameter and are designed for use in wells having limited access. After the pump is lowered to the sample depth within the well, water enters the pump, filling both tubes to the water level in the well. The pressure line is pressurized using compressed gas, and water is displaced from this tube into the sample line. A one-way flow valve at the pump intake prevents the displaced water from flowing back into the well. Once the water is in the sample line, another one-way valve prevents the water from flowing back toward the sample pump after pressure is released. Pressure is alternatively applied and released until a column of water is forced to the surface. The process is repeated at several depths within the well to complete a point profile of water quality with depth.

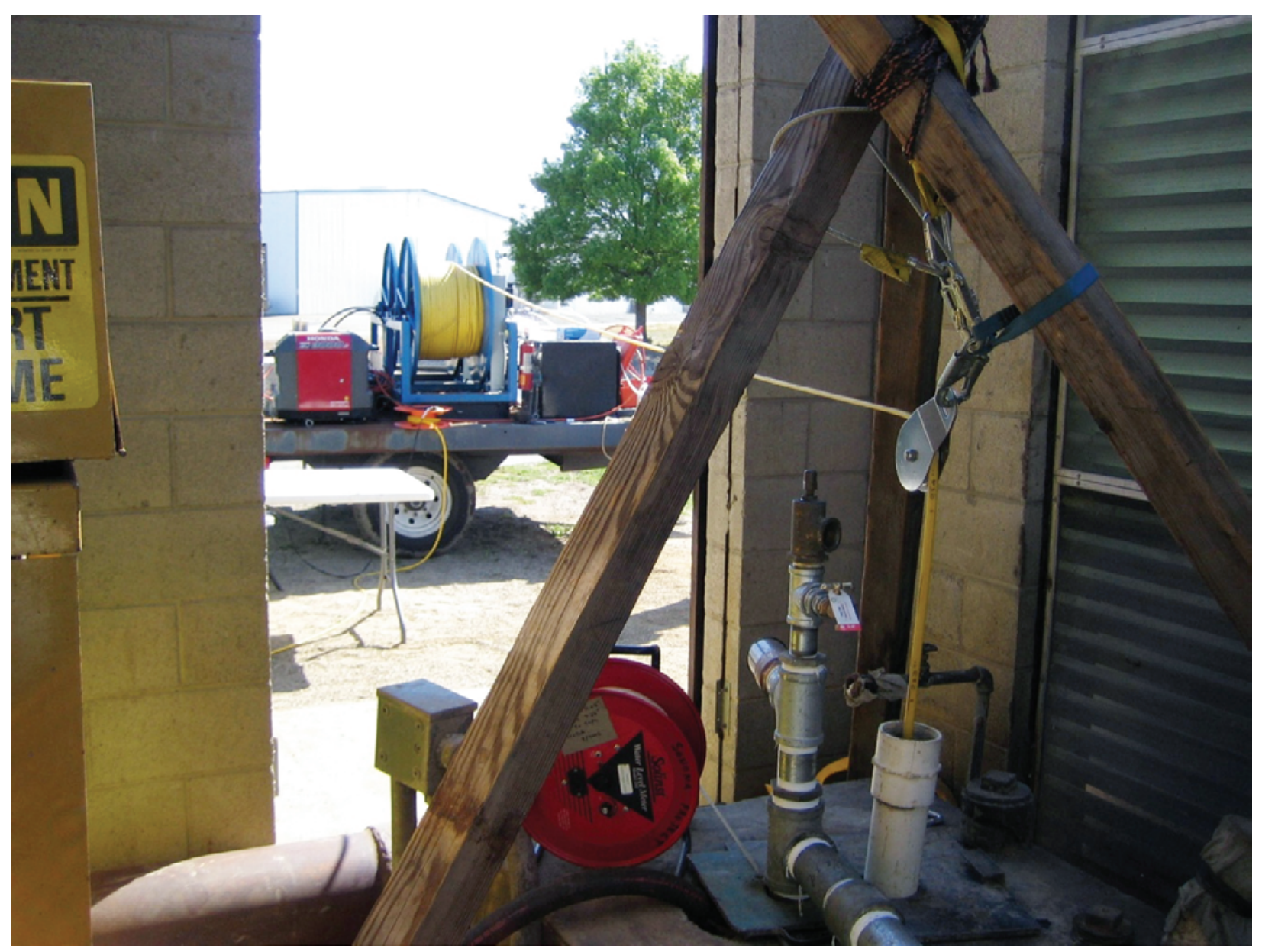

Photograph by Loren Metzger, U.S. Geological Survey, 2008

Figure 49. Depth-dependent sampling, City of Stockton well 001N007E31C001M (SSS-5), Stockton, California, March 26, 2008. 


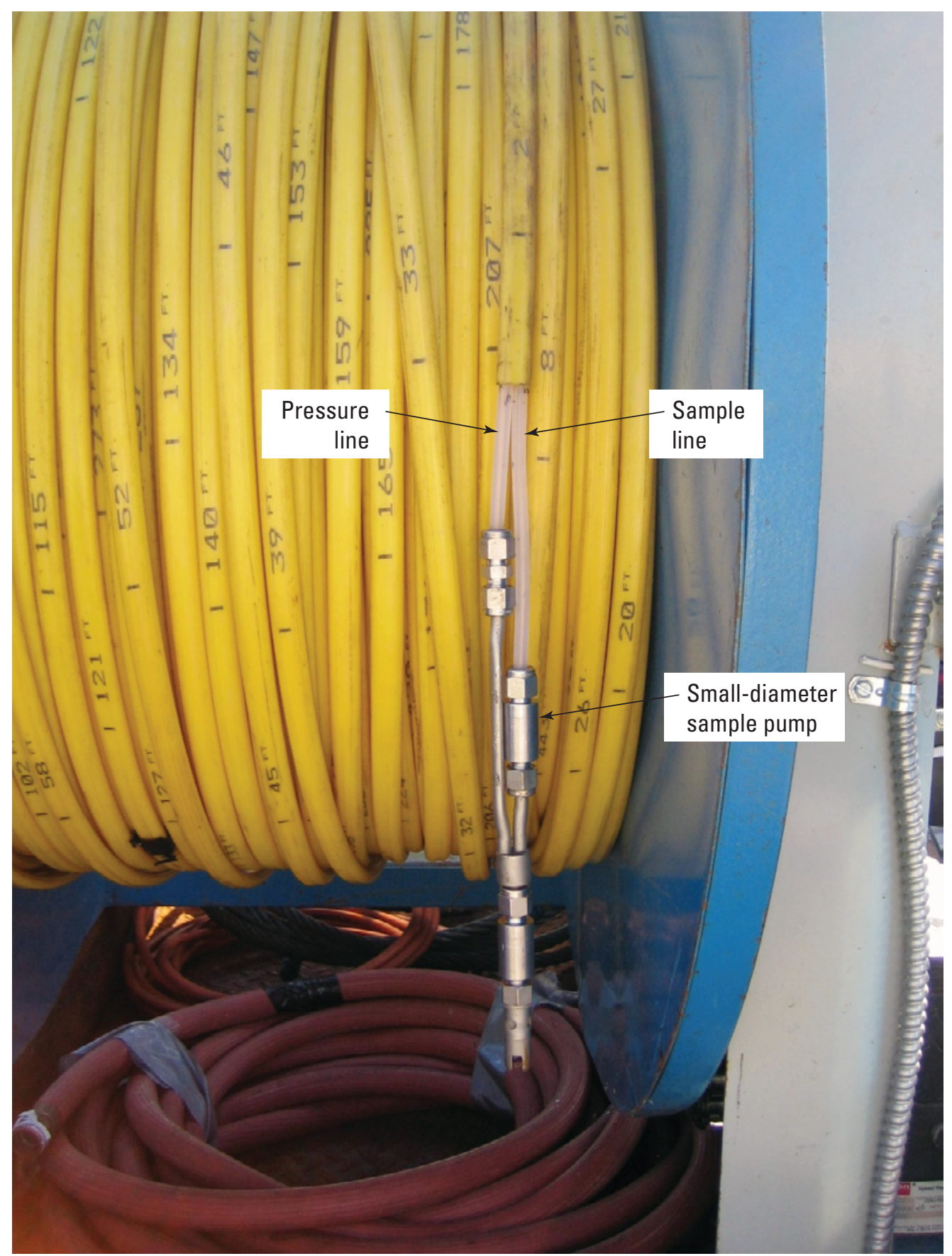

Photograph by Loren Metzger, U.S. Geological Survey, 2008.

Figure 50. Hose-reel with small diameter sample pump used for depth-dependent water-quality sampling, March 26, 2008. 
If the concentration of a constituent at the first sample depth $\left(C_{1}\right)$ and the second sample depth $\left(C_{2}\right)$ in a profile within a well are known, and the flow rate of water at the two sample depths $\left(Q_{1}\right.$ and $Q_{2}$, respectively) are known on the basis of wellbore flow data discussed previously, the concentration in water entering the well from the aquifer in the intervening interval $\left(C_{\mathrm{a}}\right)$ can be calculated according to the following equation (Izbicki and others, 1999):

$$
\left[\left(C_{1} Q_{1} C_{2} Q_{2}\right) / Q_{a}\right]=C_{a}
$$

where

$$
\begin{aligned}
& Q_{a}=\left(Q_{1}-Q_{2}\right), \text { and } \\
& Q_{a} \text { is the quantity of water entering the well } \\
& \text { between the two sample depths. This } \\
& \text { calculation assumes conservation of mass } \\
& \text { and conservative (simple, non-reactive) } \\
& \text { mixing. }
\end{aligned}
$$

Measured nutrient, water-chemistry, and isotopic data for depth-dependent sampling sites are provided in tables 18, $\underline{19}$, and 20, respectively. Calculated depth-dependent concentrations of selected constituents entering the well between sample interval, were determined by using the above equation.. Associated geophysical logs, well-construction data, depthdependent water-quality data, and the calculated concentrations of selected constituents entering the well between sample intervals are shown in figures $22-\underline{33}$. Construction data for sampled depth-dependent wells are provided in table 21.

\section{Core and Cuttings Samples}

\section{Pore-Water samples}

Core material collected from fine-grained deposits during drilling at selected multiple-well sites was squeezed in a hydraulic press (Manheim and others, 1994) to extract pore water. These data were used to assess the source of high-chloride water in interstitial pore fluids in fine-grained deposits that could not be sampled by wells. Extracted pore water was filtered as it discharged from the press and was analyzed for $\mathrm{pH}$ and specific conductance. Extracted pore water was then shipped to the NWQL in Denver for analysis for chloride, bromide, iodide, boron, and barium and for the stable isotopes of oxygen and hydrogen $\left(\delta^{18} \mathrm{O}\right.$ and $\delta \mathrm{D}$, respectively) according to methods in table 10 . Results of analysis are given in table 22.

\section{Acid Extractions from Core and Cutting Material}

Trace elements were extracted from selected core material and cuttings, collected at selected multiple-well sites, at the USGS San Diego Laboratory by using the method described by Izbicki, Ball, and others (2008), which was modified from Chao and Sanzolone (1989). Samples were processed by mixing 10 grams of oven-dried core material or drill cuttings with $50 \mathrm{~mL}$ of $4-\mathrm{N} \mathrm{HNO}_{3}$ solution and were then shaken for 24 hours in a wrist shaker. The solid material was then separated from the supernate by centrifugation, and the remaining solution was filtered through a $0.45 \mu \mathrm{m}$ pore-sized filter. Samples were shipped to the NWQL in Denver for analysis for arsenic, chromium, iron, manganese, vanadium, and uranium by ICP-MS (table 10). Results are presented in table 23.

These data were used to assess the possible source of high-concentration of selected trace metals that may be found within water in interstitial pore fluids in fine-grained deposits that could not be sampled by wells.

\section{Accessing Data}

Users of the data presented in this report are encouraged to access information through the USGS National Water Information System Web page (NWISWeb) available at http://waterdata.usgs.gov/nwis/.

NWISWeb serves as an interface to a database network of site information and real-time, groundwater, surface-water, and water-quality data collected from locations throughout the United States and elsewhere. Data are updated from the database network on a regularly scheduled basis.

Data are retrieved by category and geographic area and can be selectively refined by specific location or parameter field. NWISWeb can output water-level and water-quality graphs, site maps, and data tables (in HTML and ASCII format) and develop site-selection lists.

Post-publication updates to data presented in this report are made to the USGS NWIS and are available online through NWISWeb. Additional geophysical logs, sample collection notes, and other information not contained in NWIS are kept on file at the USGS office in San Diego, California. Formal requests for specific data should be made to the USGS California Water Science Center, CSUS Campus, Placer Hall, 6000 J Street, Room 4000, Sacramento, CA 95819-6129, http://ca.water.usgs.gov. 
Table 18. Nutrient data for water from selected depth-dependent wells, Eastern San Joaquin Groundwater Subbasin, California, 2004-8.

[Site locations are shown in figure 20. State well number, see well-numbering diagram in text. The five-digit number in parentheses below the constituent name is the U.S. Geological Survey parameter code used to uniquely identify a specific constituent or property. Samples analyzed by U.S. Geological Survey National Water Quality Laboratory (NWQL) in Arvada, Colorado, and the U.S. Geological Survey Laboratory in San Diego, California (SD). Sample depth in feet below land surface. Abbreviations: E, estimated value; ft, feet; hh:mm, hour: minute; LSD, land surface datum; mg/L, milligrams per liter; mm/dd/yyyy, month/day/ year; NAVD 88; North American Vertical Datum of 1988; -, no data; <, less than value shown]

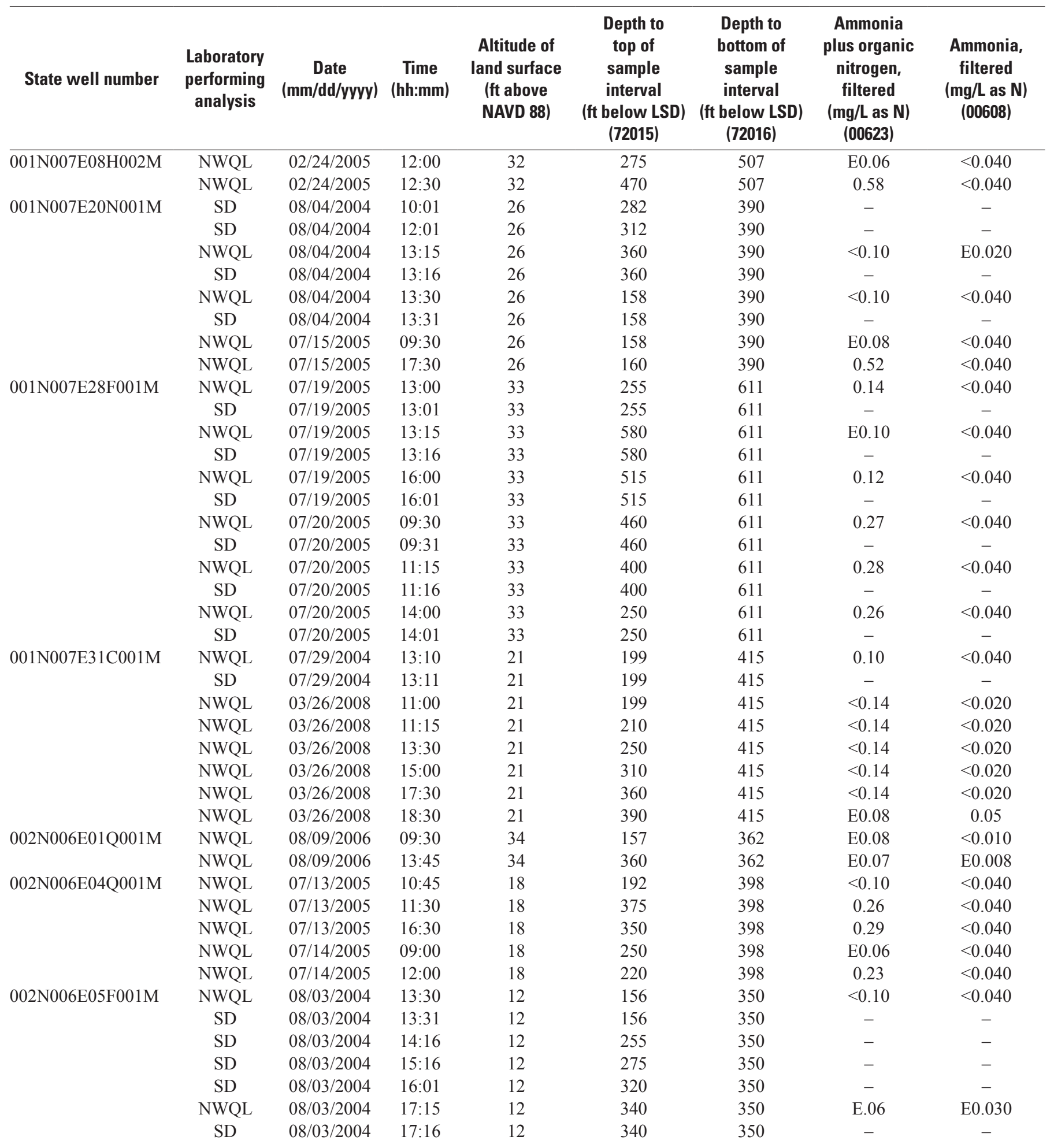


Table 18. Nutrient data for water from selected depth-dependent wells, Eastern San Joaquin Groundwater Subbasin, California, 2004-8.-Continued

[Site locations are shown in figure 20. State well number, see well-numbering diagram in text. The five-digit number in parentheses below the constituent name is the U.S. Geological Survey parameter code used to uniquely identify a specific constituent or property. Samples analyzed by U.S. Geological Survey National Water Quality Laboratory (NWQL) in Arvada, Colorado, and the U.S. Geological Survey Laboratory in San Diego, California (SD). Sample depth in feet below land surface. Abbreviations: E, estimated value; ft, feet; hh:mm, hour: minute; LSD, land surface datum; mg/L, milligrams per liter; mm/dd/yyyy, month/day/ year; NAVD 88; North American Vertical Datum of 1988; -, no data; <, less than value shown]

\begin{tabular}{|c|c|c|c|c|c|c|c|c|}
\hline State well number & $\begin{array}{c}\text { Laboratory } \\
\text { performing } \\
\text { analysis }\end{array}$ & $\begin{array}{c}\text { Date } \\
\text { (mm/dd/yyyy) }\end{array}$ & $\begin{array}{c}\text { Time } \\
\text { (hh:mm) }\end{array}$ & $\begin{array}{c}\text { Altitude of } \\
\text { land surface } \\
\text { (ft above } \\
\text { NAVD 88) }\end{array}$ & $\begin{array}{c}\text { Depth to } \\
\text { top of } \\
\text { sample } \\
\text { interval } \\
\text { (ft below LSD) } \\
\text { (72015) }\end{array}$ & $\begin{array}{c}\text { Depth to } \\
\text { bottom of } \\
\text { sample } \\
\text { interval } \\
\text { (ft below LSD) } \\
\text { (72016) }\end{array}$ & $\begin{array}{c}\text { Ammonia } \\
\text { plus organic } \\
\text { nitrogen, } \\
\text { filtered } \\
\text { (mg/L as } \mathrm{N} \text { ) } \\
\text { (00623) }\end{array}$ & $\begin{array}{c}\text { Ammonia, } \\
\text { filtered } \\
\text { (mg/L as N) } \\
(00608)\end{array}$ \\
\hline 002N006E11H003M & NWQL & $06 / 19 / 2007$ & $12: 00$ & 27 & 260 & 495 & $<0.10$ & $<0.020$ \\
\hline & NWQL & 08/08/2006 & $17: 20$ & 35 & 425 & 445 & E0.06 & E0.009 \\
\hline \multirow[t]{9}{*}{ 002N006E24P004M } & NWQL & 08/05/2004 & $09: 30$ & 25 & 200 & 520 & $<0.10$ & $<0.040$ \\
\hline & $\mathrm{SD}$ & 08/05/2004 & $09: 31$ & 25 & 200 & 520 & - & - \\
\hline & SD & $08 / 05 / 2004$ & $11: 01$ & 25 & 244 & 520 & - & - \\
\hline & SD & $08 / 05 / 2004$ & $12: 01$ & 25 & 278 & 520 & - & - \\
\hline & SD & $08 / 05 / 2004$ & $14: 01$ & 25 & 300 & 520 & - & - \\
\hline & $\mathrm{SD}$ & $08 / 05 / 2004$ & $17: 46$ & 25 & 506 & 520 & - & - \\
\hline & NWQL & $01 / 27 / 2005$ & 09:00 & 25 & 400 & 520 & - & $<0.040$ \\
\hline & NWQL & $01 / 27 / 2005$ & $13: 00$ & 25 & 275 & 520 & - & $<0.040$ \\
\hline & NWQL & $01 / 28 / 2005$ & $08: 30$ & 25 & 200 & 520 & - & $<0.040$ \\
\hline \multirow[t]{4}{*}{ 002N006E27L001M } & NWQL & $02 / 16 / 2005$ & $15: 00$ & 15 & - & 495 & - & $<0.040$ \\
\hline & NWQL & $02 / 17 / 2005$ & $11: 30$ & 15 & - & 495 & - & $<0.040$ \\
\hline & NWQL & $02 / 17 / 2005$ & $19: 00$ & 15 & - & 495 & - & $<0.040$ \\
\hline & NWQL & $02 / 18 / 2005$ & $10: 00$ & 15 & - & 495 & - & $<0.040$ \\
\hline
\end{tabular}


Table 18. Nutrient data for water from selected depth-dependent wells, Eastern San Joaquin Groundwater Subbasin, California, 2004-8.-Continued

[Site locations are shown in figure 20. State well number, see well-numbering diagram in text. The five-digit number in parentheses below the constituent name is the U.S. Geological Survey parameter code used to uniquely identify a specific constituent or property. Samples analyzed by U.S. Geological Survey National Water Quality Laboratory (NWQL) in Arvada, Colorado, and the U.S. Geological Survey Laboratory in San Diego, California (SD). Sample depth in feet below land surface. Abbreviations: E, estimated value; ft, feet; hh:mm, hour: minute; LSD, land surface datum; mg/L, milligrams per liter; mm/dd/yyyy, month/day/ year; NAVD 88; North American Vertical Datum of 1988; -, no data; <, less than value shown]

\begin{tabular}{|c|c|c|c|c|c|c|c|c|}
\hline State well number & $\begin{array}{l}\text { Laboratory } \\
\text { performing } \\
\text { analysis }\end{array}$ & $\begin{array}{c}\text { Date } \\
\text { (mm/dd/yyyy) }\end{array}$ & $\begin{array}{c}\text { Time } \\
\text { (hh:mm) }\end{array}$ & $\begin{array}{c}\text { Nitrate } \\
\text { plus nitrite, } \\
\text { filtered } \\
\text { (mg/L as N) } \\
\text { (00631) }\end{array}$ & $\begin{array}{c}\text { Nitrate, } \\
\text { filtered } \\
(\mathrm{mg} / \mathrm{L} \text { as } \mathrm{N}) \\
(00618)\end{array}$ & $\begin{array}{c}\text { Nitrite, } \\
\text { filtered } \\
(\mathrm{mg} / \mathrm{L} \text { as N) } \\
(00613)\end{array}$ & $\begin{array}{l}\text { Orthophosphate, } \\
\text { filtered } \\
\text { (mg/L as P) } \\
\text { (00671) }\end{array}$ & $\begin{array}{c}\text { Phosphorus, } \\
\text { filtered } \\
\text { (mg/L as } \mathrm{P} \text { ) } \\
(00666)\end{array}$ \\
\hline \multirow[t]{10}{*}{ 001N007E08H002M } & NWQL & $02 / 24 / 2005$ & $12: 00$ & 11.3 & 11.2 & 0.110 & 0.060 & 0.06 \\
\hline & NWQL & $02 / 24 / 2005$ & $12: 30$ & 13.1 & 12.9 & 0.255 & 0.020 & 0.04 \\
\hline & $\mathrm{SD}$ & 08/04/2004 & $10: 01$ & - & 0.29 & $<0.030$ & $<0.500$ & - \\
\hline & SD & 08/04/2004 & $12: 01$ & - & $<0.06$ & $<0.030$ & $<0.500$ & - \\
\hline & NWQL & 08/04/2004 & $13: 15$ & $<0.06$ & $<0.06$ & $<0.008$ & 0.110 & 0.10 \\
\hline & $\mathrm{SD}$ & 08/04/2004 & $13: 16$ & - & $<0.06$ & $<0.030$ & $<0.500$ & - \\
\hline & NWQL & 08/04/2004 & $13: 30$ & 3.48 & 3.48 & $<0.008$ & 0.050 & 0.04 \\
\hline & $\mathrm{SD}$ & 08/04/2004 & $13: 31$ & - & 3.38 & $<0.030$ & E0.300 & - \\
\hline & NWQL & $07 / 15 / 2005$ & 09:30 & 3.49 & 3.49 & $<0.008$ & 0.030 & 0.05 \\
\hline & NWQL & $07 / 15 / 2005$ & $17: 30$ & 7.91 & 7.91 & $<0.008$ & $<0.020$ & E0.03 \\
\hline \multirow[t]{12}{*}{ 001N007E28F001M } & NWQL & 07/19/2005 & $13: 00$ & 4.19 & 4.19 & $<0.008$ & 0.030 & E0.04 \\
\hline & $\mathrm{SD}$ & 07/19/2005 & $13: 01$ & - & 4.18 & $<0.100$ & $<2$ & - \\
\hline & NWQL & 07/19/2005 & $13: 15$ & $<0.06$ & $<0.06$ & $<0.008$ & 0.040 & 0.05 \\
\hline & SD & 07/19/2005 & $13: 16$ & - & $<0.06$ & $<0.030$ & $<0.500$ & - \\
\hline & NWQL & 07/19/2005 & $16: 00$ & 1.89 & 1.89 & $<0.008$ & 0.030 & 0.04 \\
\hline & SD & 07/19/2005 & $16: 01$ & - & 1.75 & $<0.030$ & $<0.500$ & - \\
\hline & NWQL & $07 / 20 / 2005$ & 09:30 & $<0.06$ & $<0.06$ & $<0.008$ & 0.040 & 0.07 \\
\hline & SD & $07 / 20 / 2005$ & 09:31 & - & $<0.06$ & $<0.030$ & $<0.500$ & - \\
\hline & NWQL & $07 / 20 / 2005$ & $11: 15$ & $<0.06$ & $<0.06$ & $<0.008$ & 0.030 & 0.05 \\
\hline & $\mathrm{SD}$ & $07 / 20 / 2005$ & $11: 16$ & - & $<0.06$ & $<0.030$ & $<0.500$ & - \\
\hline & NWQL & $07 / 20 / 2005$ & $14: 00$ & $<0.06$ & $<0.06$ & $<0.008$ & 0.030 & 0.05 \\
\hline & $\mathrm{SD}$ & $07 / 20 / 2005$ & $14: 01$ & - & $<0.06$ & $<0.030$ & $<0.500$ & - \\
\hline \multirow[t]{8}{*}{ 001N007E31C001M } & NWQL & $07 / 29 / 2004$ & $13: 10$ & 2.92 & 2.92 & $<0.008$ & 0.030 & E0.02 \\
\hline & $\mathrm{SD}$ & 07/29/2004 & $13: 11$ & - & 2.88 & $<0.030$ & $<1$ & - \\
\hline & NWQL & $03 / 26 / 2008$ & $11: 00$ & 3.25 & 3.24 & 0.012 & 0.033 & E0.03 \\
\hline & NWQL & $03 / 26 / 2008$ & $11: 15$ & 2.04 & 2.02 & 0.016 & 0.031 & E0.02 \\
\hline & NWQL & 03/26/2008 & $13: 30$ & 3.12 & 3.07 & 0.050 & 0.028 & E0.02 \\
\hline & NWQL & $03 / 26 / 2008$ & $15: 00$ & 3.31 & 3.27 & 0.045 & 0.026 & E0.02 \\
\hline & NWQL & 03/26/2008 & $17: 30$ & 4.32 & 4.27 & 0.056 & 0.026 & $<0.04$ \\
\hline & NWQL & $03 / 26 / 2008$ & $18: 30$ & 2.92 & 2.76 & 0.154 & 0.016 & $<0.04$ \\
\hline \multirow[t]{2}{*}{ 002N006E01Q001M } & NWQL & 08/09/2006 & 09:30 & 4.57 & 4.57 & $<0.002$ & 0.050 & E0.02 \\
\hline & NWQL & 08/09/2006 & $13: 45$ & 4.16 & 4.16 & $<0.002$ & 0.050 & E0.02 \\
\hline \multirow[t]{5}{*}{ 002N006E04Q001M } & NWQL & $07 / 13 / 2005$ & $10: 45$ & 2.18 & 2.18 & $<0.008$ & E0.010 & E0.03 \\
\hline & NWQL & $07 / 13 / 2005$ & $11: 30$ & $<0.06$ & $<0.06$ & $<0.008$ & $<0.020$ & E0.02 \\
\hline & NWQL & $07 / 13 / 2005$ & $16: 30$ & $<0.06$ & $<0.06$ & $<0.008$ & E0.010 & E0.02 \\
\hline & NWQL & $07 / 14 / 2005$ & 09:00 & 0.52 & 0.52 & $<0.008$ & E0.020 & E0.03 \\
\hline & NWQL & $07 / 14 / 2005$ & $12: 00$ & 1.80 & 1.80 & $<0.008$ & E0.010 & E0.03 \\
\hline \multirow[t]{7}{*}{ 002N006E05F001M } & NWQL & 08/03/2004 & $13: 30$ & 2.54 & $\mathrm{E} 2.54$ & E0.005 & 0.030 & E0.02 \\
\hline & $\mathrm{SD}$ & 08/03/2004 & $13: 31$ & - & 2.49 & $<0.030$ & $<1$ & - \\
\hline & SD & 08/03/2004 & $14: 16$ & - & $<0.06$ & $<0.030$ & $<0.500$ & - \\
\hline & SD & 08/03/2004 & $15: 16$ & - & $<0.06$ & $<0.030$ & $<0.500$ & - \\
\hline & SD & 08/03/2004 & $16: 01$ & - & $<0.06$ & $<0.030$ & $<0.500$ & - \\
\hline & NWQL & 08/03/2004 & $17: 15$ & $<0.06$ & $<0.06$ & $<0.008$ & 0.040 & E0.04 \\
\hline & $\mathrm{SD}$ & 08/03/2004 & $17: 16$ & - & $<0.06$ & $<0.030$ & $<0.500$ & - \\
\hline
\end{tabular}


Table 18. Nutrient data for water from selected depth-dependent wells, Eastern San Joaquin Groundwater Subbasin, California, 2004-8.-Continued

[Site locations are shown in figure 20. State well number, see well-numbering diagram in text. The five-digit number in parentheses below the constituent name is the U.S. Geological Survey parameter code used to uniquely identify a specific constituent or property. Samples analyzed by U.S. Geological Survey National Water Quality Laboratory (NWQL) in Arvada, Colorado, and the U.S. Geological Survey Laboratory in San Diego, California (SD). Sample depth in feet below land surface. Abbreviations: E, estimated value; ft, feet; hh:mm, hour: minute; LSD, land surface datum; mg/L, milligrams per liter; mm/dd/yyyy, month/day/ year; NAVD 88; North American Vertical Datum of 1988; -, no data; <, less than value shown]

\begin{tabular}{|c|c|c|c|c|c|c|c|c|}
\hline State well number & $\begin{array}{l}\text { Laboratory } \\
\text { performing } \\
\text { analysis }\end{array}$ & $\begin{array}{c}\text { Date } \\
\text { (mm/dd/yyyy) }\end{array}$ & $\begin{array}{c}\text { Time } \\
\text { (hh:mm) }\end{array}$ & $\begin{array}{c}\text { Nitrate } \\
\text { plus nitrite, } \\
\text { filtered } \\
\text { (mg/L as } \mathrm{N} \text { ) } \\
\text { (00631) }\end{array}$ & $\begin{array}{c}\text { Nitrate, } \\
\text { filtered } \\
(\mathrm{mg} / \mathrm{L} \text { as N) } \\
(00618)\end{array}$ & $\begin{array}{c}\text { Nitrite, } \\
\text { filtered } \\
\text { (mg/L as } N \text { ) } \\
\text { (00613) }\end{array}$ & $\begin{array}{c}\text { Orthophosphate, } \\
\text { filtered } \\
\text { (mg/L as P) } \\
\text { (00671) }\end{array}$ & $\begin{array}{c}\text { Phosphorus, } \\
\text { filtered } \\
\text { (mg/L as P) } \\
(00666)\end{array}$ \\
\hline \multirow[t]{2}{*}{ 002N006E11H003M } & NWQL & $06 / 19 / 2007$ & $12: 00$ & 2.04 & 2.04 & $<0.002$ & 0.037 & E0.04 \\
\hline & NWQL & $06 / 20 / 2007$ & $14: 20$ & 1.55 & 1.55 & $<0.002$ & 0.038 & 0.04 \\
\hline \multirow{2}{*}{ 002N006E12J001M } & NWQL & $08 / 08 / 2006$ & $11: 00$ & 0.77 & 0.77 & $<0.002$ & 0.047 & E0.02 \\
\hline & NWQL & 08/08/2006 & $17: 20$ & 0.46 & 0.46 & $<0.002$ & 0.048 & $<0.04$ \\
\hline \multirow[t]{12}{*}{ 002N006E24P004M } & NWQL & 08/05/2004 & 09:30 & 1.51 & 1.51 & $<0.008$ & 0.040 & E0.03 \\
\hline & $\mathrm{SD}$ & 08/05/2004 & 09:31 & - & 1.51 & $<0.030$ & $<0.500$ & - \\
\hline & SD & $08 / 05 / 2004$ & $11: 01$ & - & 1.29 & $<0.030$ & $<0.500$ & - \\
\hline & $\mathrm{SD}$ & $08 / 05 / 2004$ & $12: 01$ & - & 1.09 & $<0.030$ & $<0.500$ & - \\
\hline & SD & $08 / 05 / 2004$ & $14: 01$ & - & 1.30 & $<0.030$ & $<0.500$ & - \\
\hline & SD & 08/05/2004 & $15: 01$ & - & 0.74 & $<0.030$ & $<0.500$ & - \\
\hline & SD & $08 / 05 / 2004$ & $16: 31$ & - & 0.74 & $<0.030$ & $<0.500$ & - \\
\hline & NWQL & 08/05/2004 & $17: 45$ & 1.05 & 1.05 & $<0.008$ & 0.070 & 0.07 \\
\hline & SD & $08 / 05 / 2004$ & $17: 46$ & - & 1.00 & $<0.030$ & $<0.500$ & - \\
\hline & NWQL & $01 / 27 / 2005$ & 09:00 & 0.69 & 0.69 & $<0.008$ & 0.034 & - \\
\hline & NWQL & $01 / 27 / 2005$ & $13: 00$ & 0.95 & 0.95 & $<0.008$ & 0.034 & - \\
\hline & NWQL & $01 / 28 / 2005$ & $08: 30$ & 1.37 & 1.37 & $<0.008$ & 0.033 & - \\
\hline \multirow[t]{4}{*}{ 002N006E27L001M } & NWQL & $02 / 16 / 2005$ & $15: 00$ & E0.04 & E0.04 & $<0.008$ & 0.034 & - \\
\hline & NWQL & $02 / 17 / 2005$ & $11: 30$ & $<0.06$ & $<0.06$ & $<0.008$ & 0.044 & - \\
\hline & NWQL & $02 / 17 / 2005$ & $19: 00$ & $<0.06$ & $<0.06$ & $<0.008$ & 0.050 & - \\
\hline & NWQL & $02 / 18 / 2005$ & $10: 00$ & E0.05 & E0.05 & $<0.008$ & 0.054 & - \\
\hline
\end{tabular}




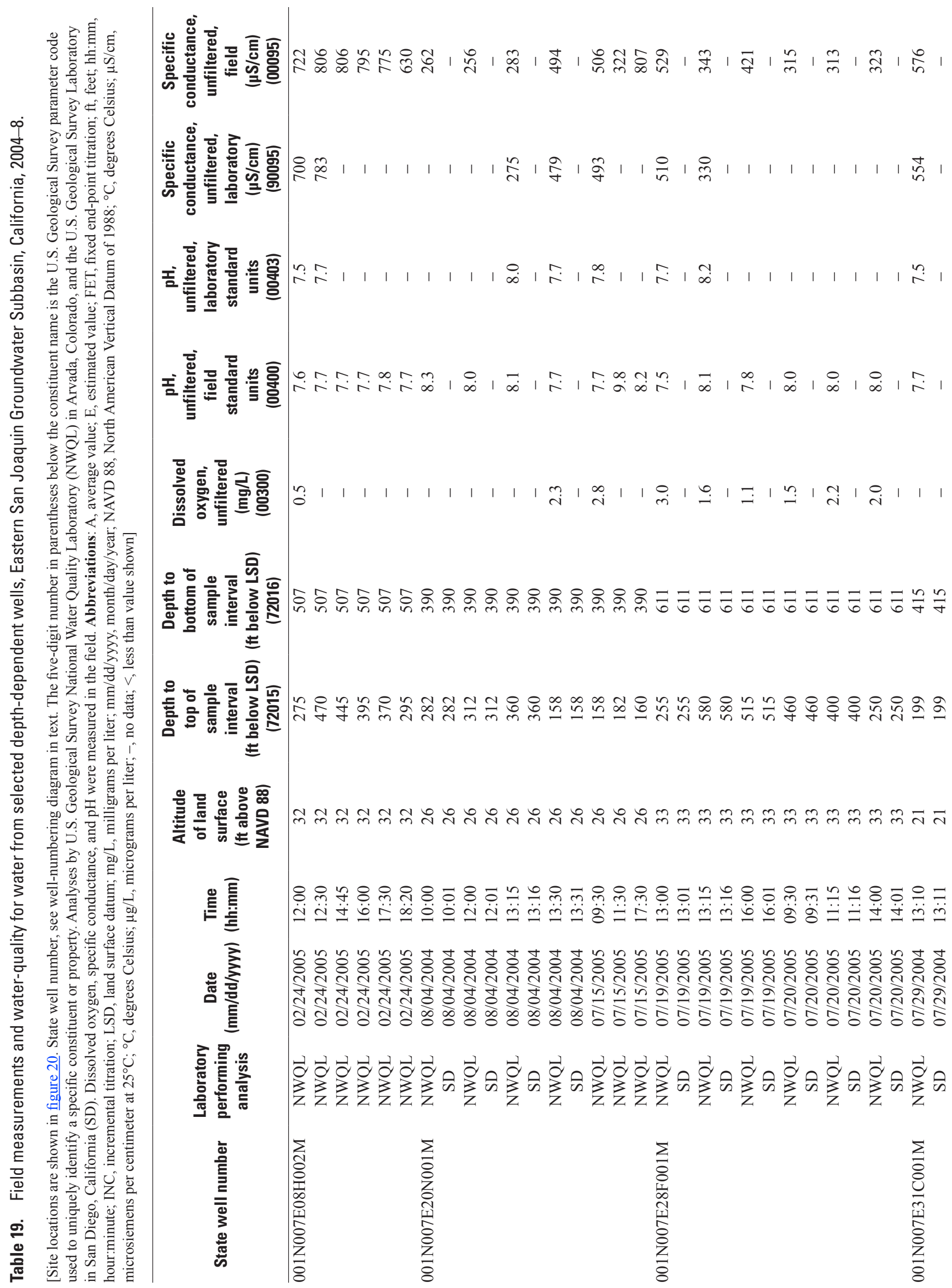



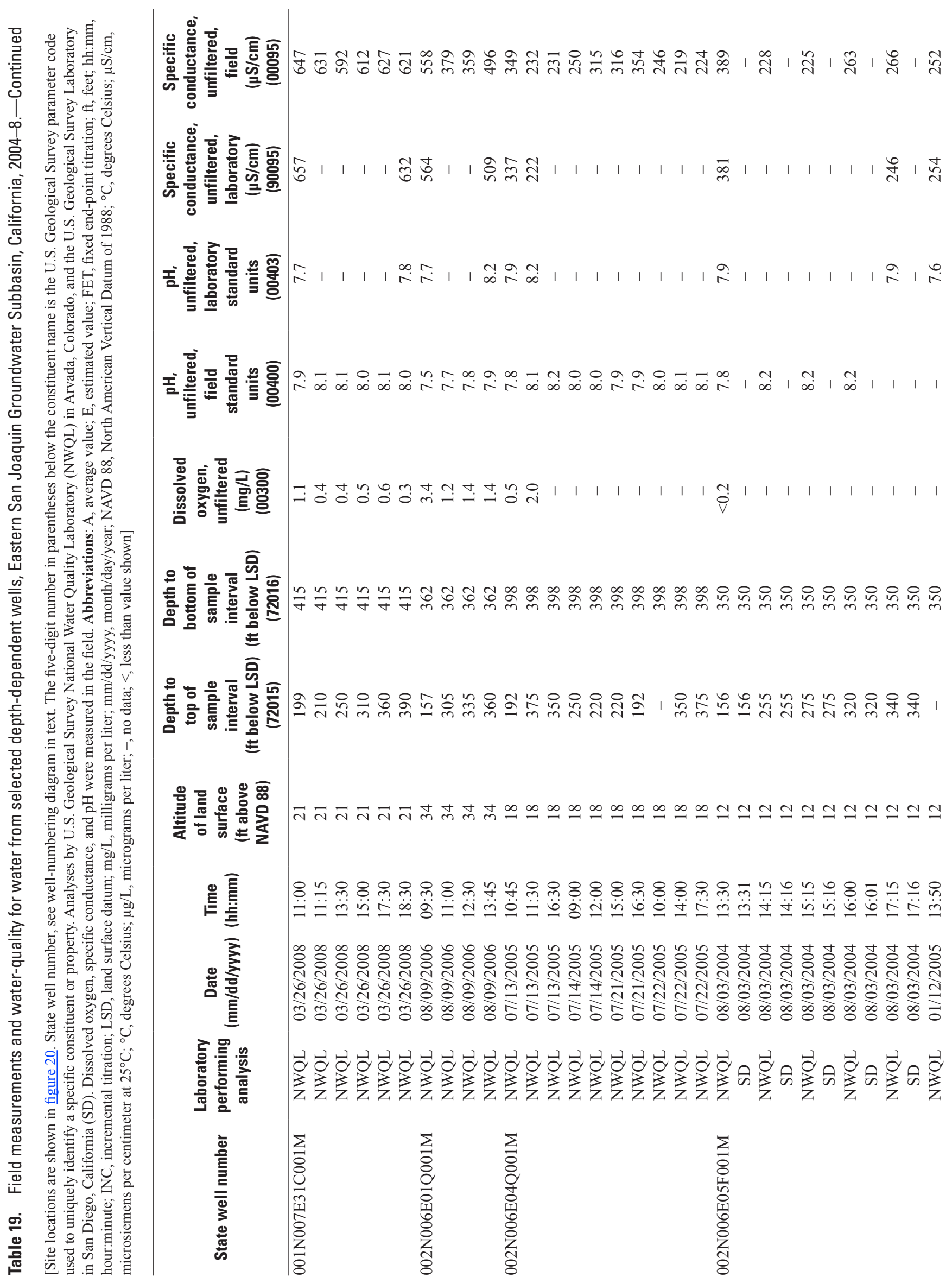

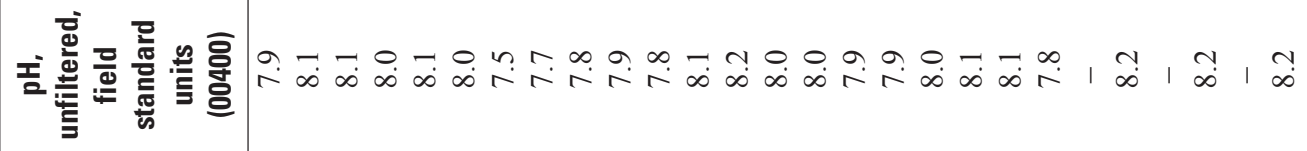

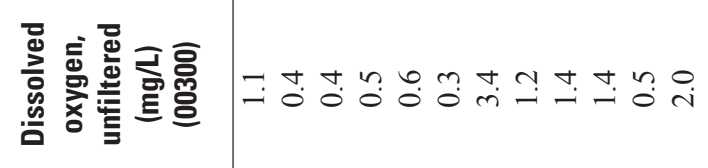

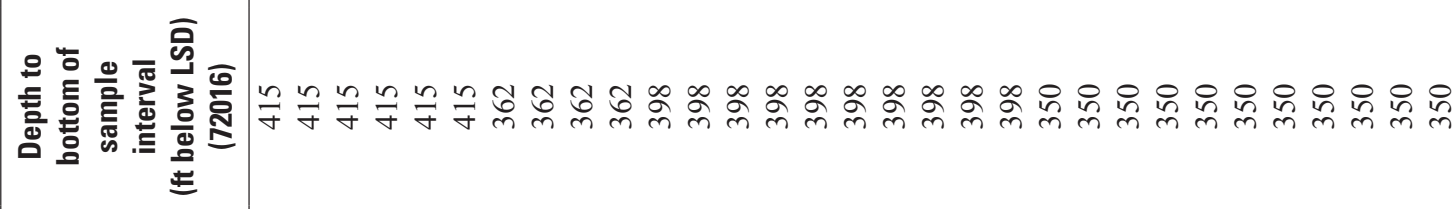

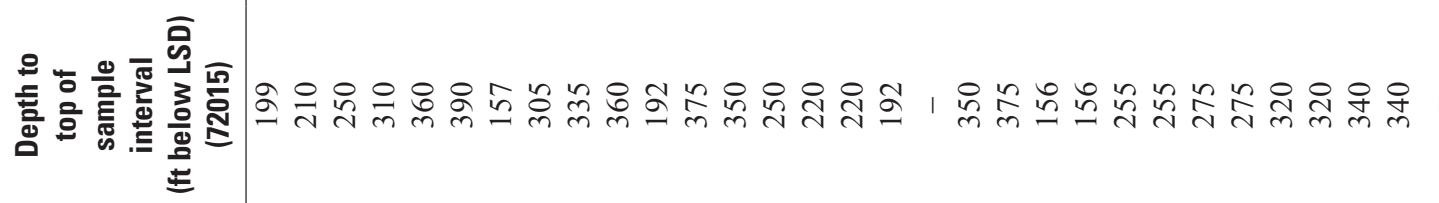

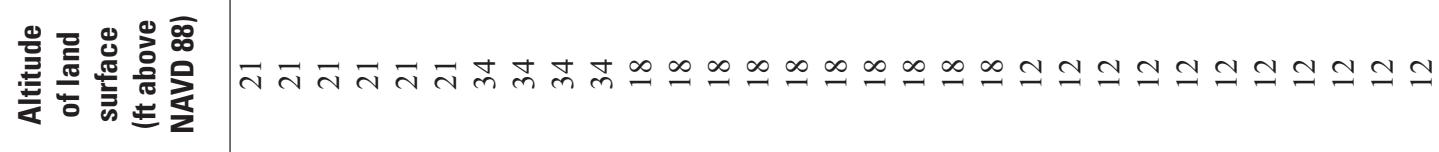

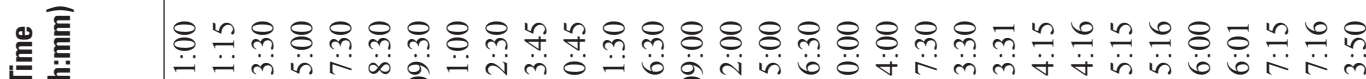

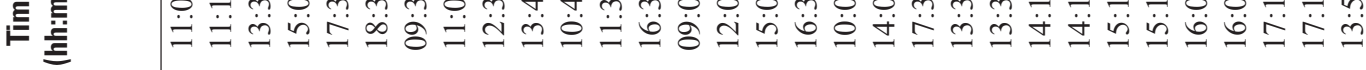
网 $\stackrel{ \pm}{*}$

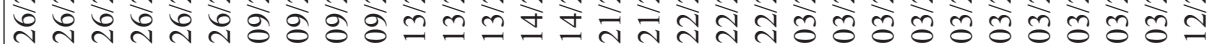

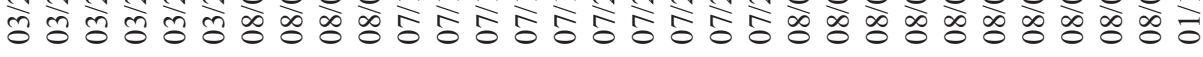

豆

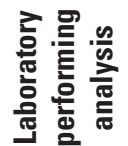

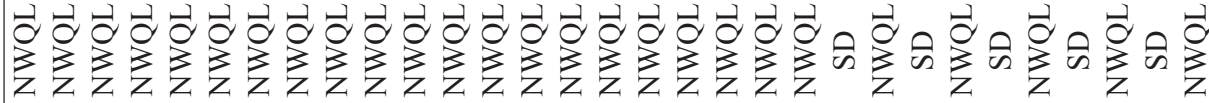

|

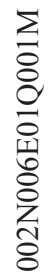

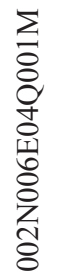

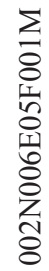




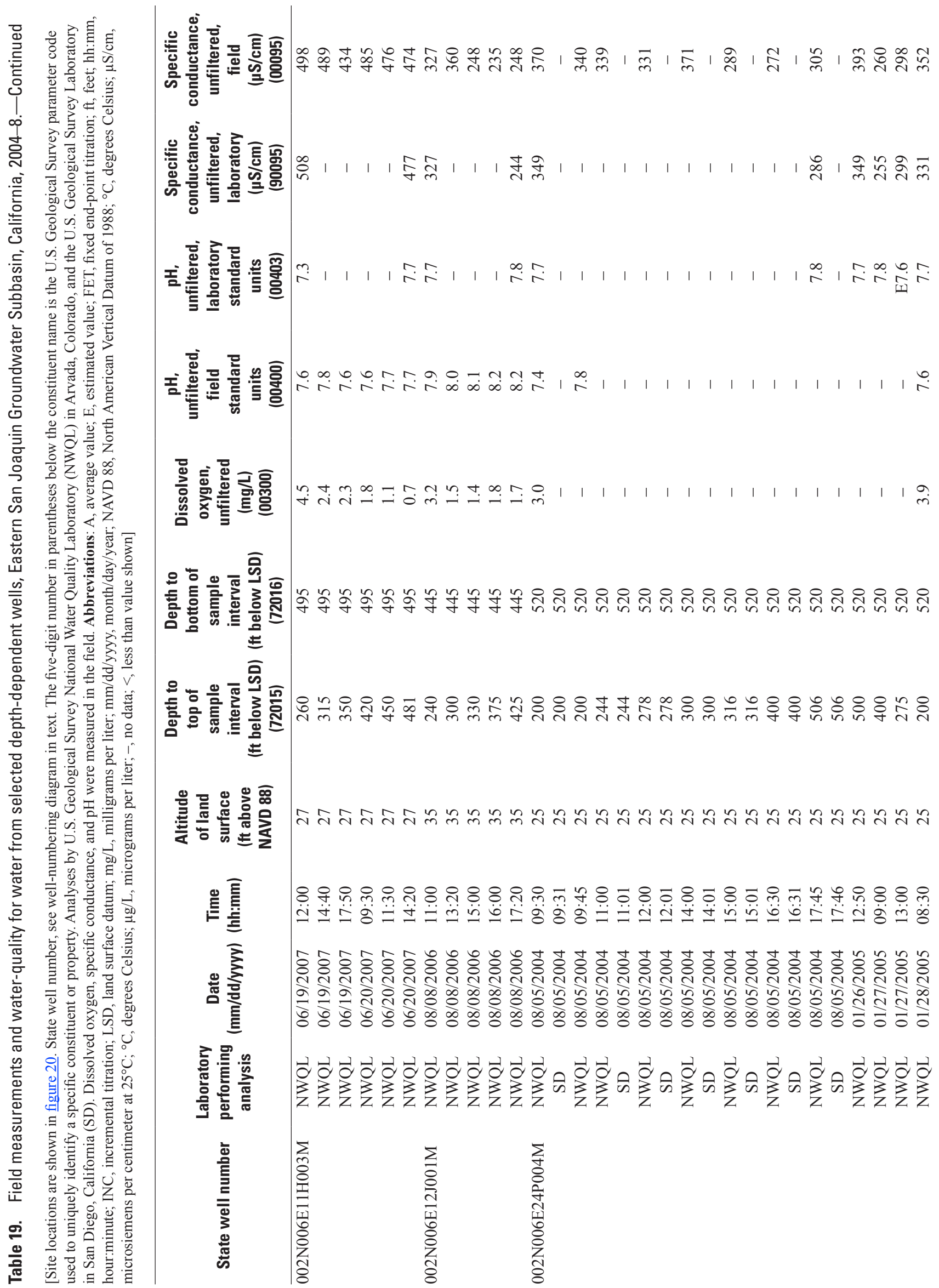




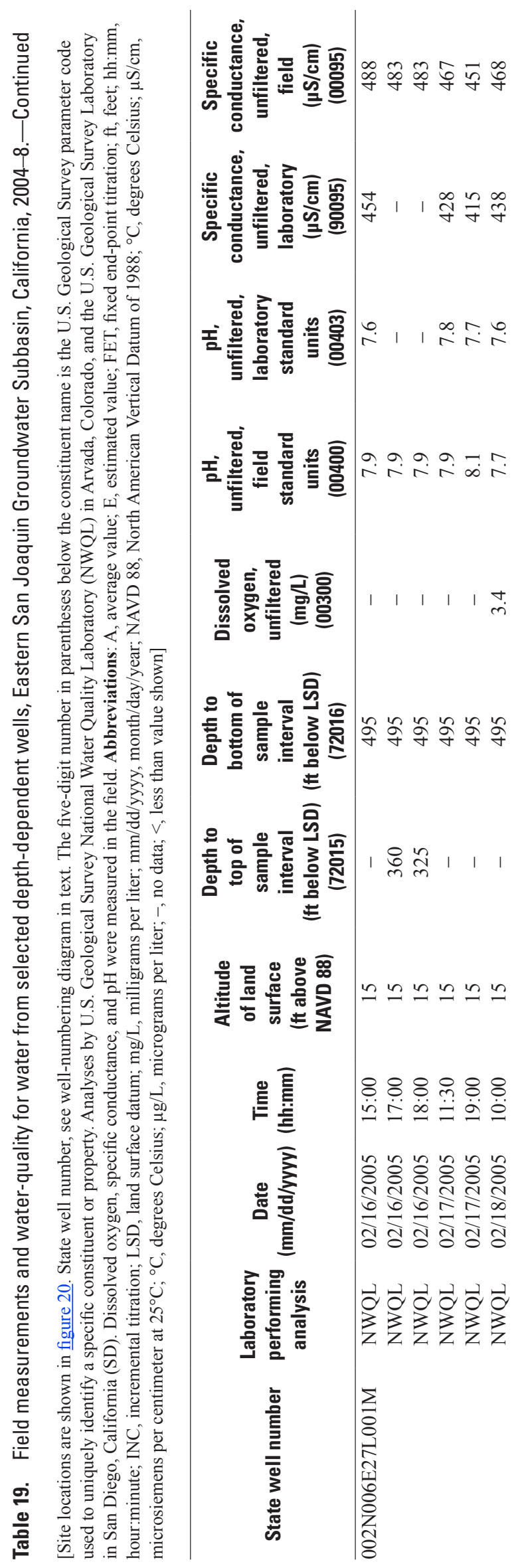




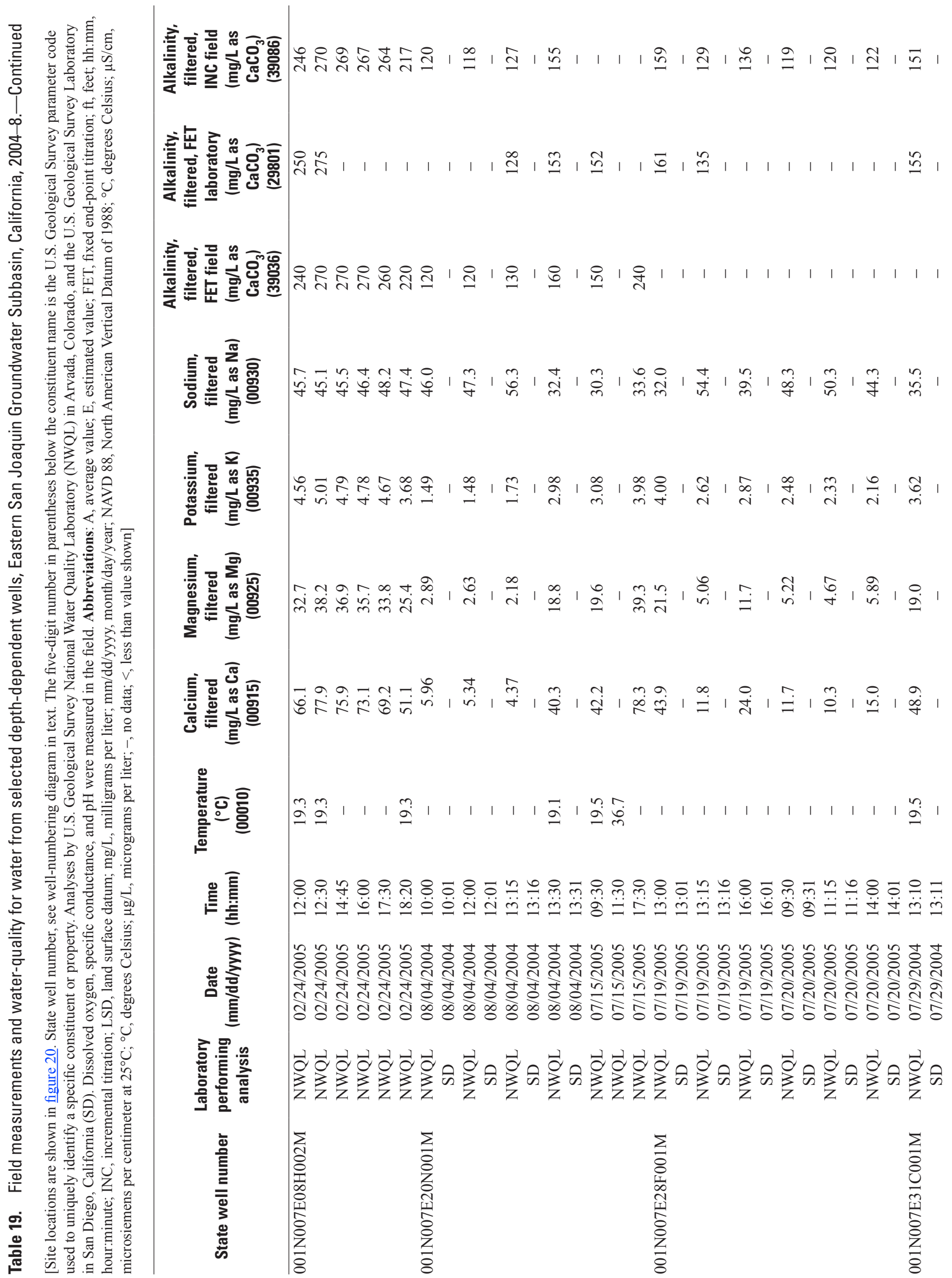




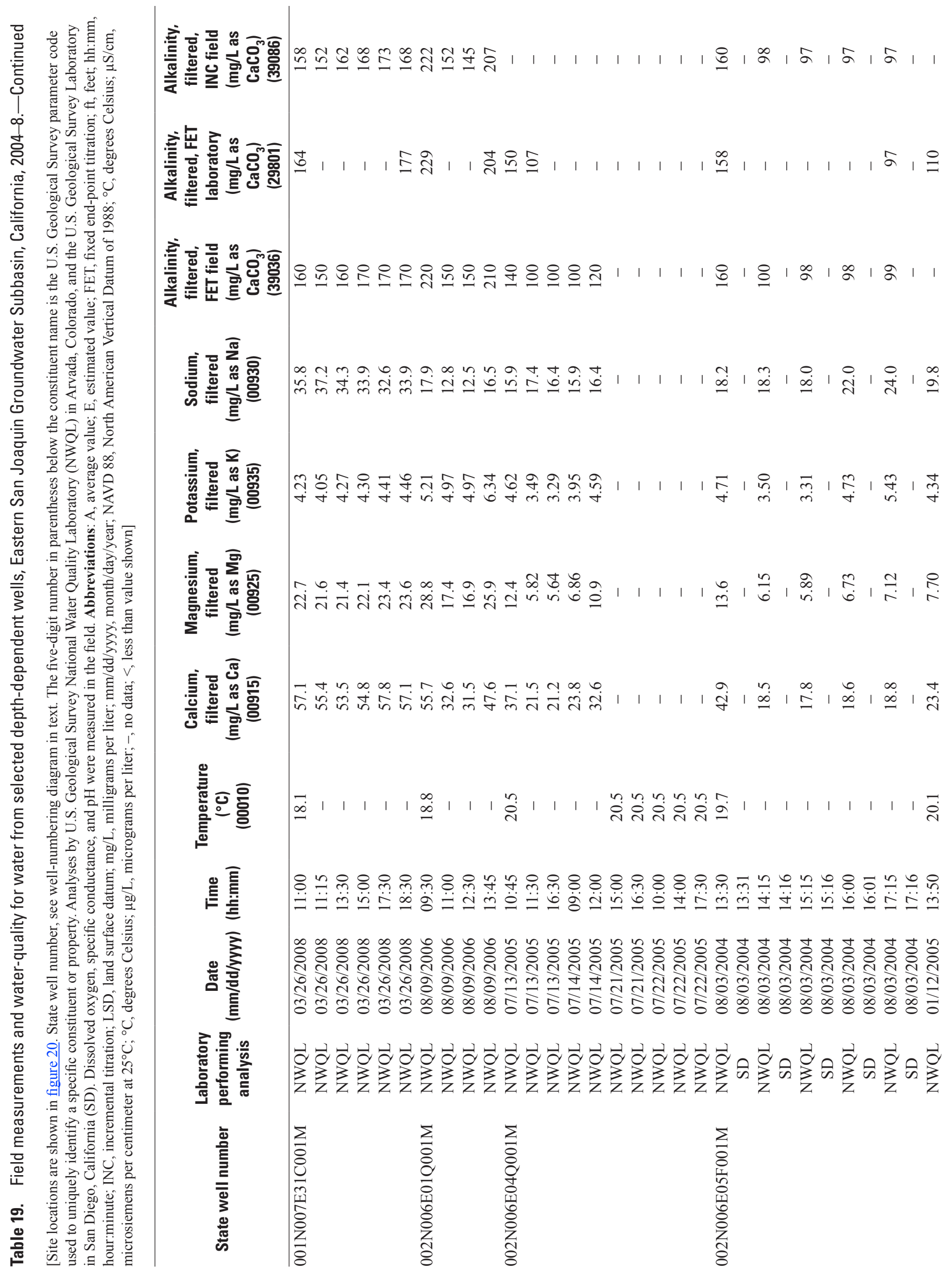




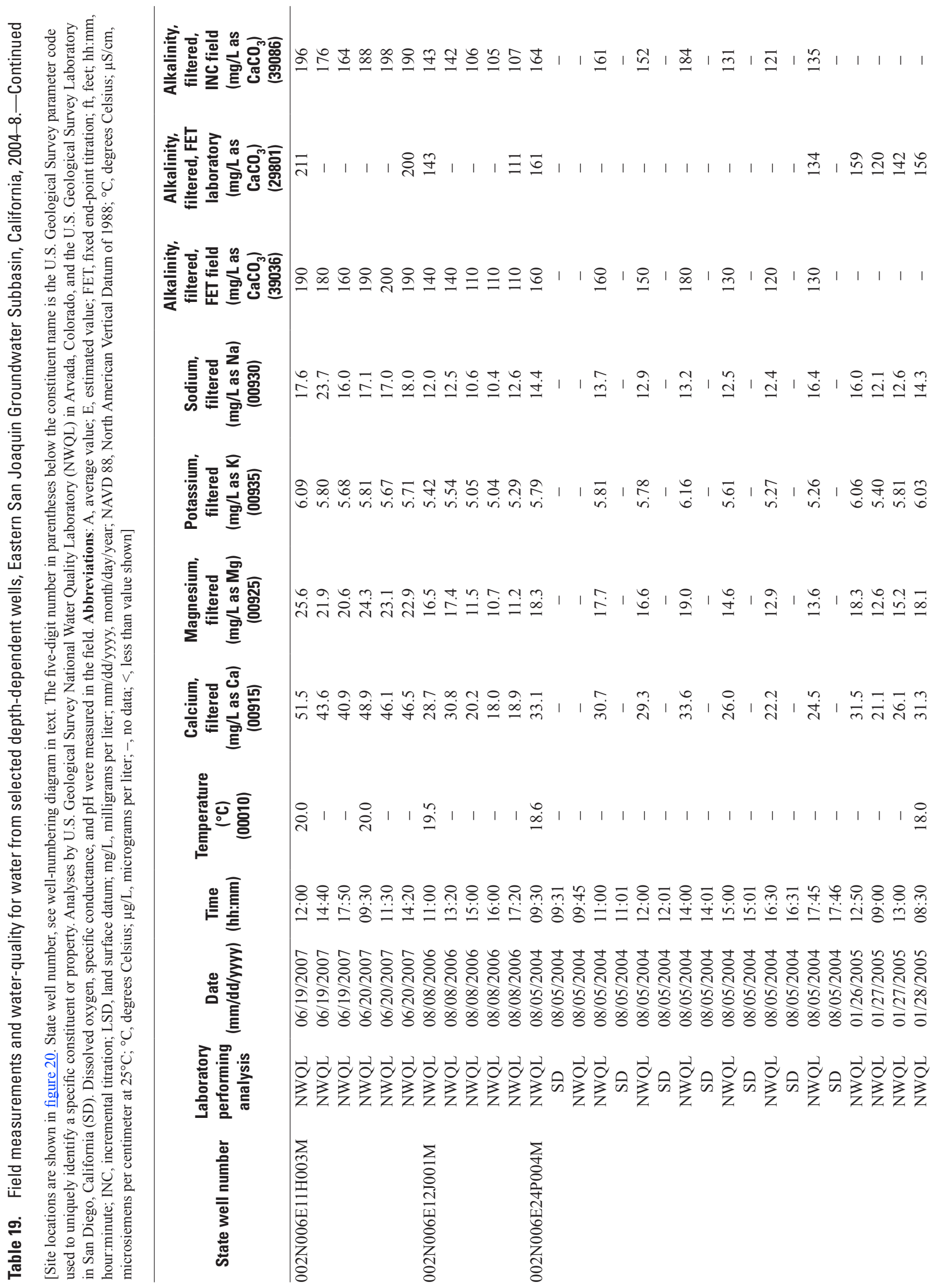




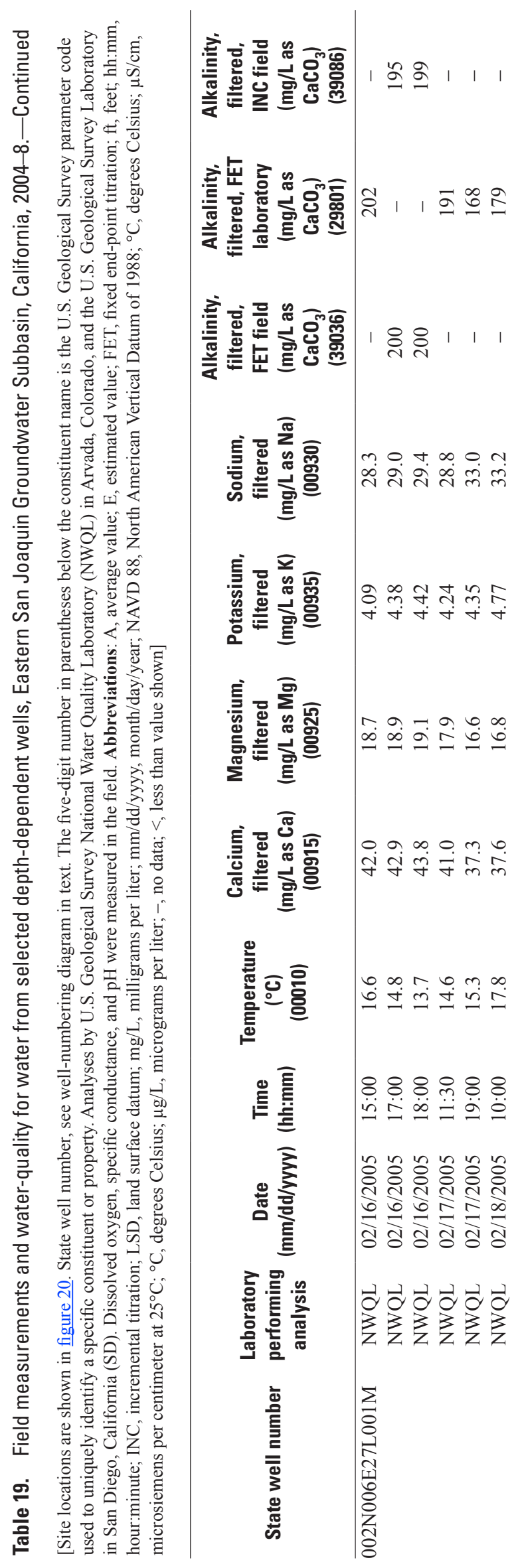




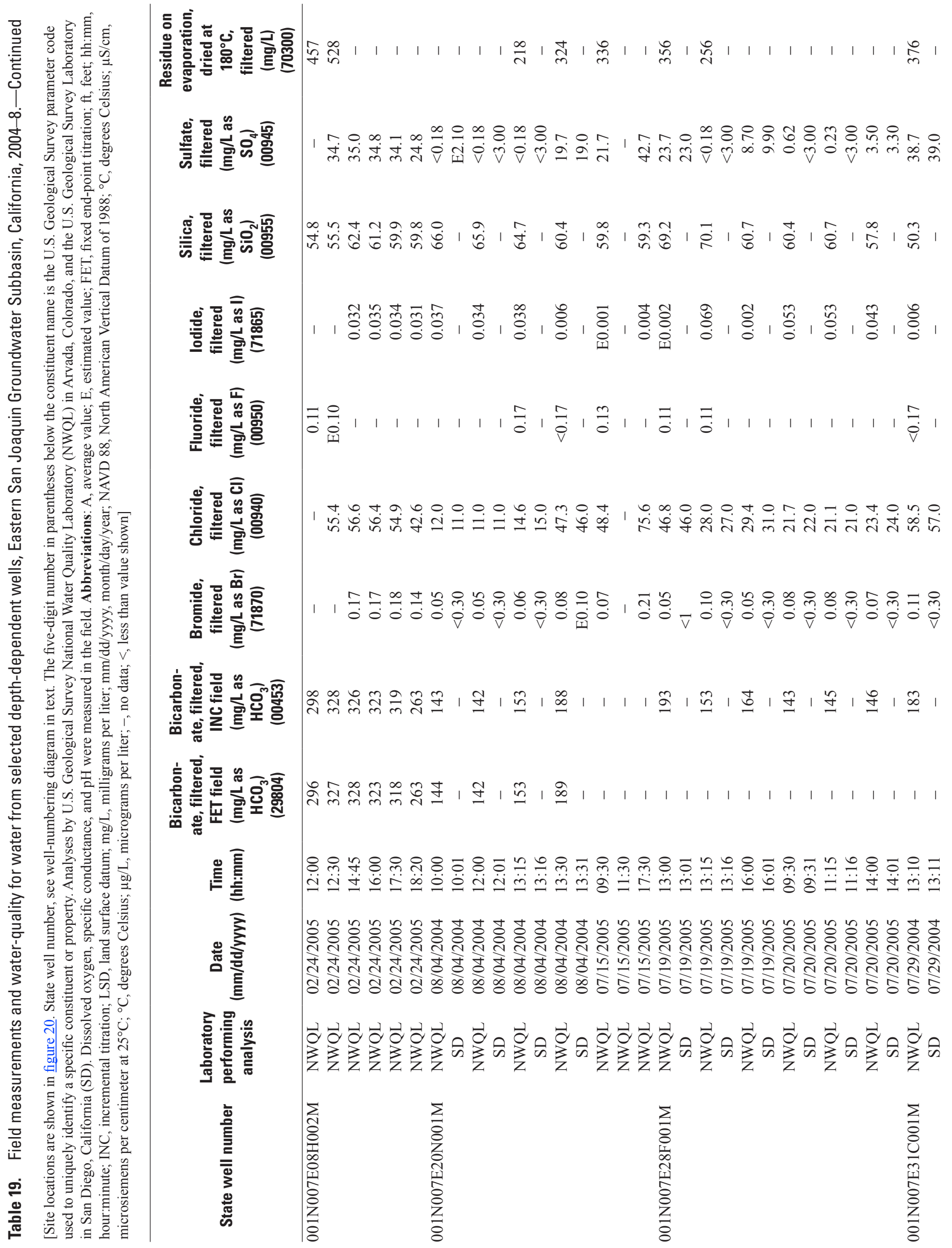




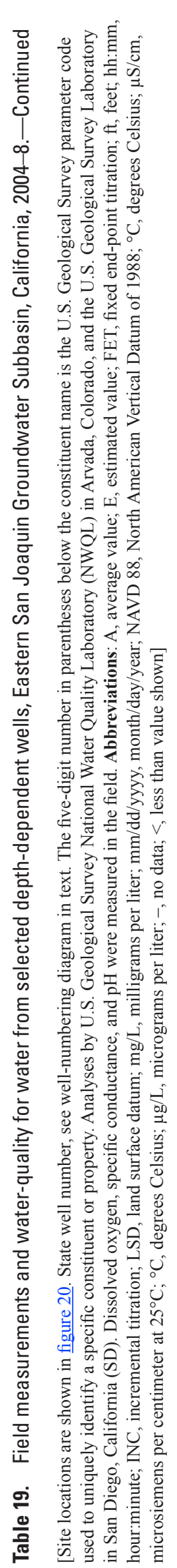

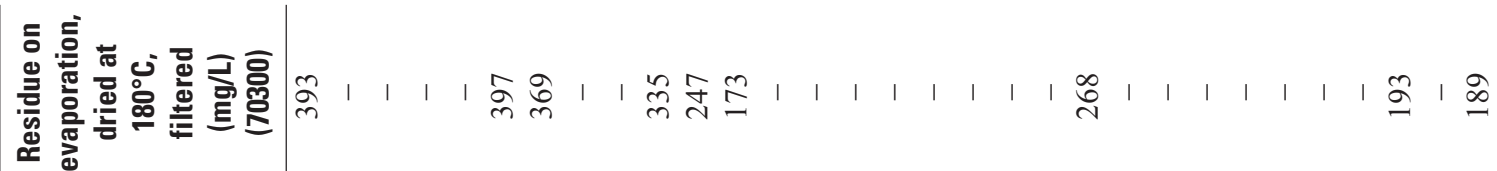

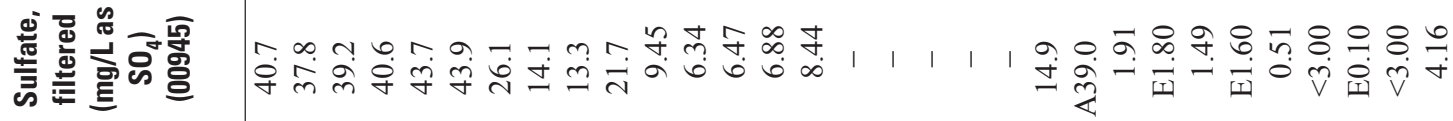

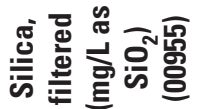

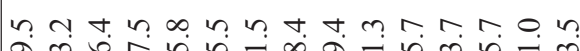

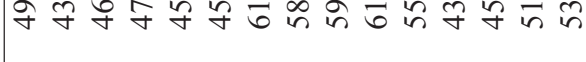

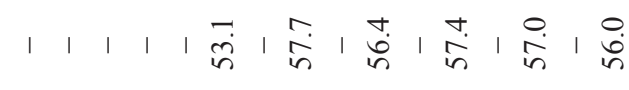

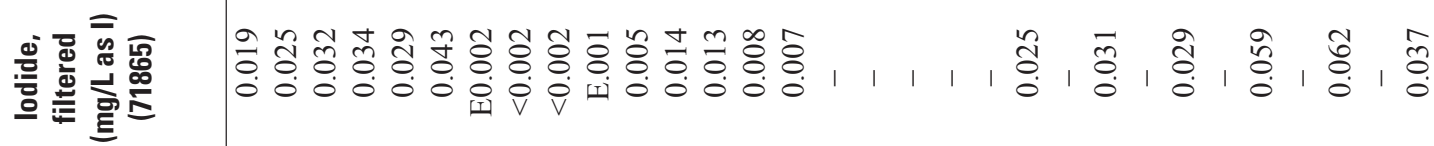

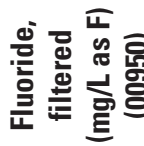
웅

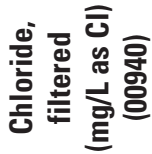

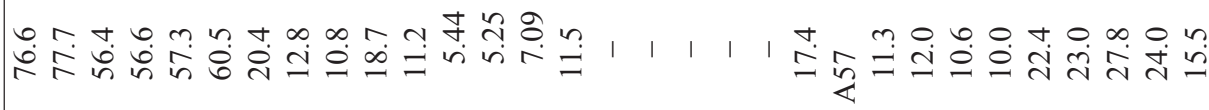

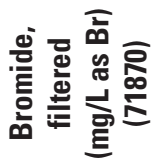

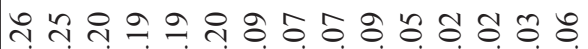

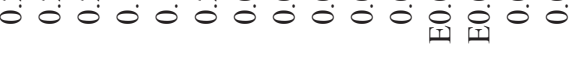
ò 웅요 言离 I

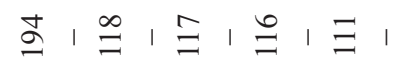
言离 |

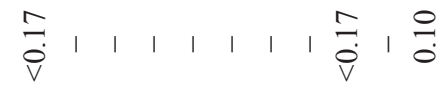
害害

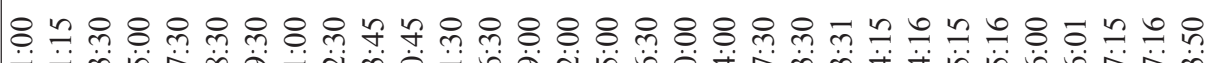

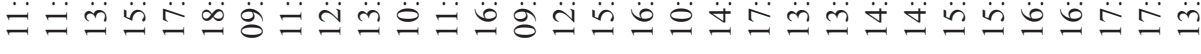
芩

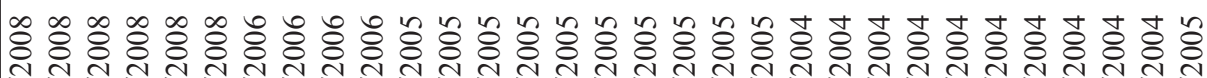

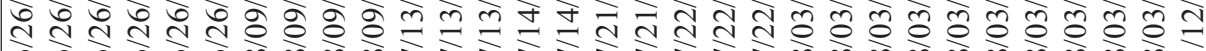
๙

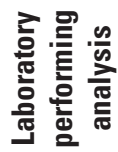

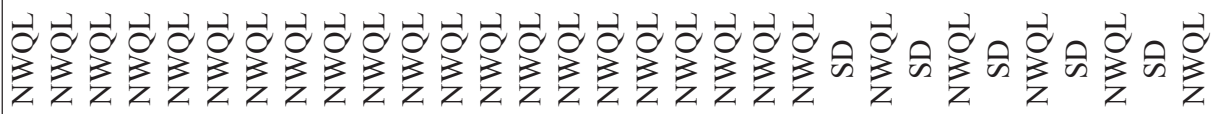

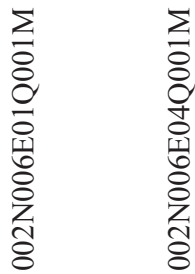

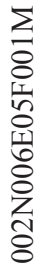




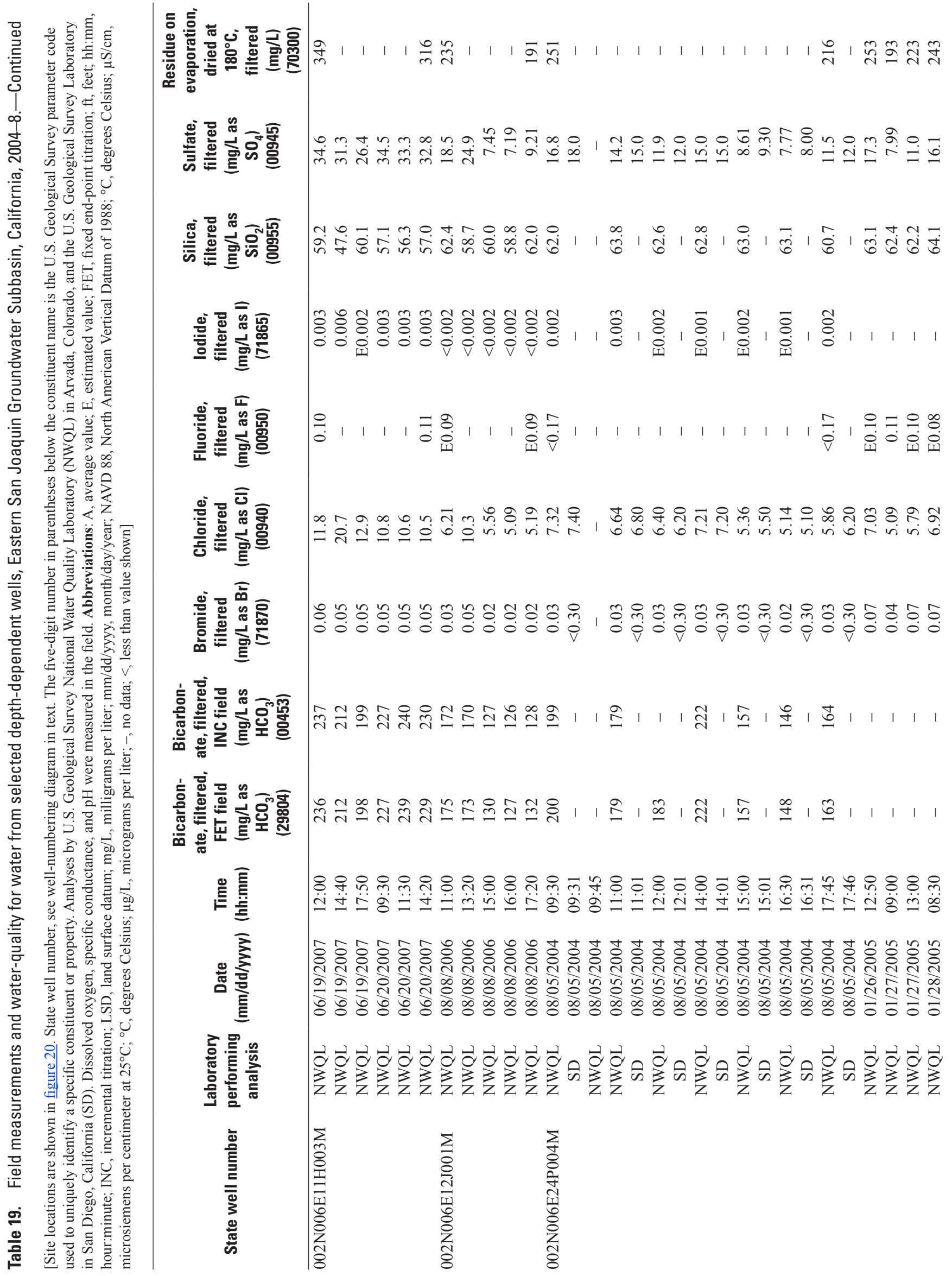




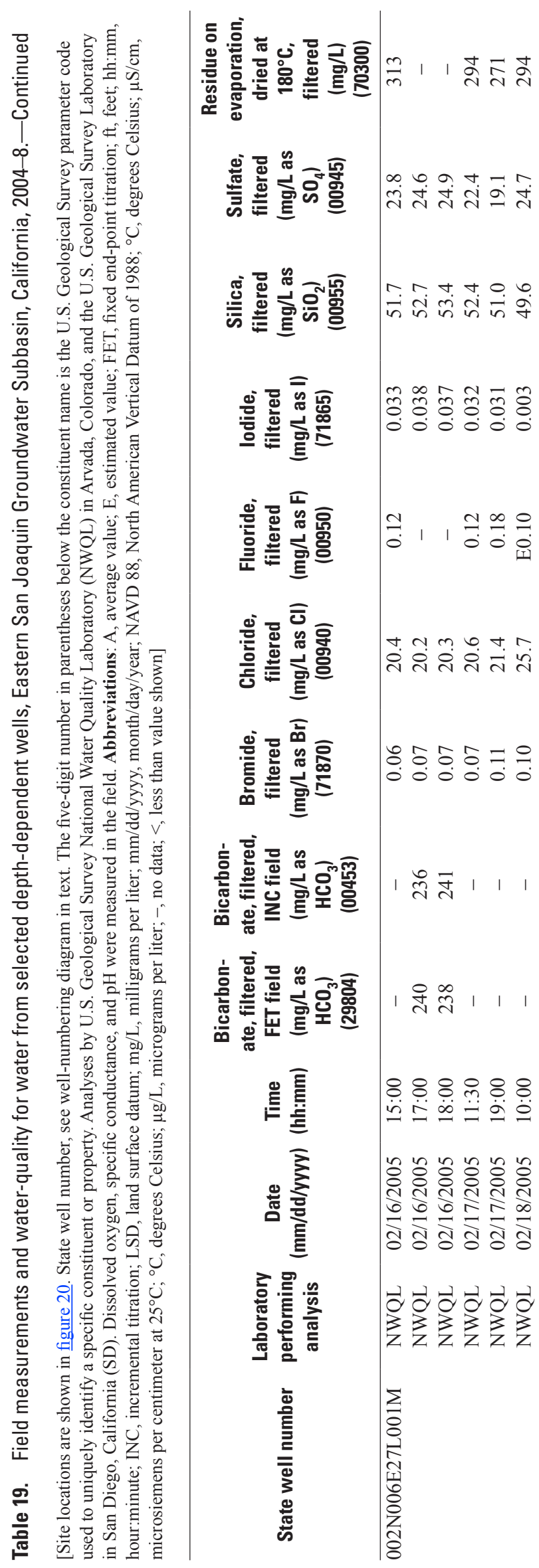




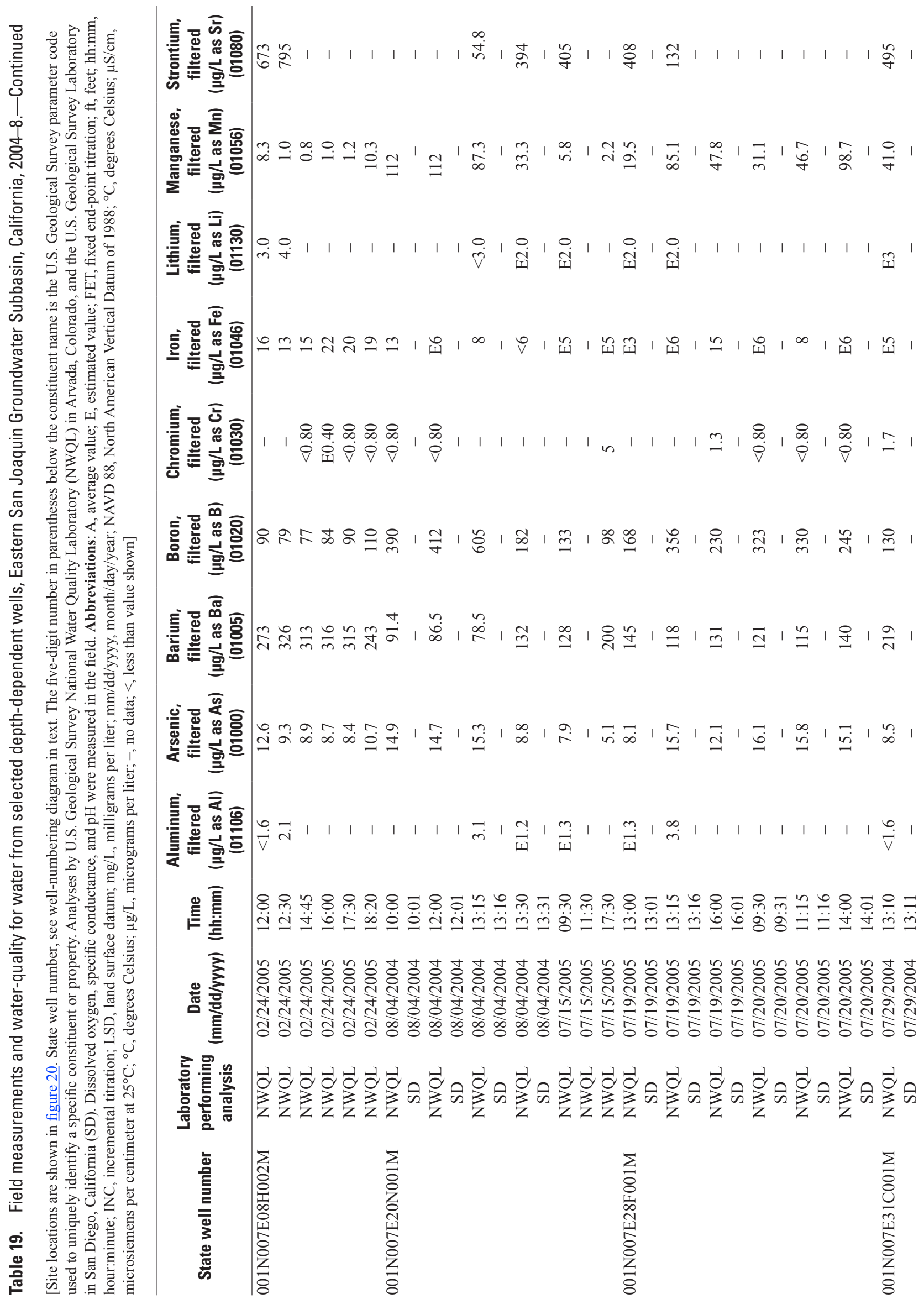




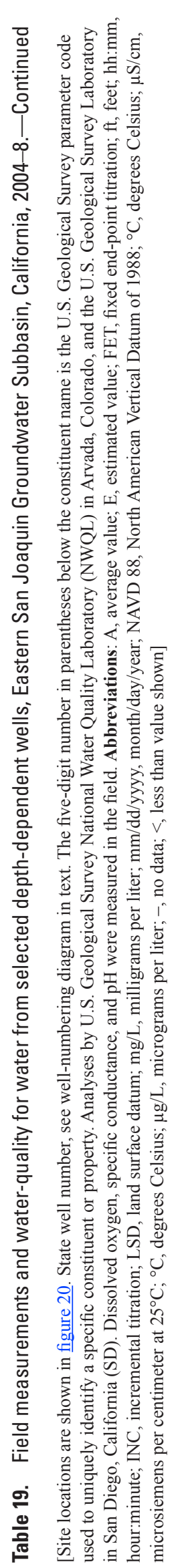

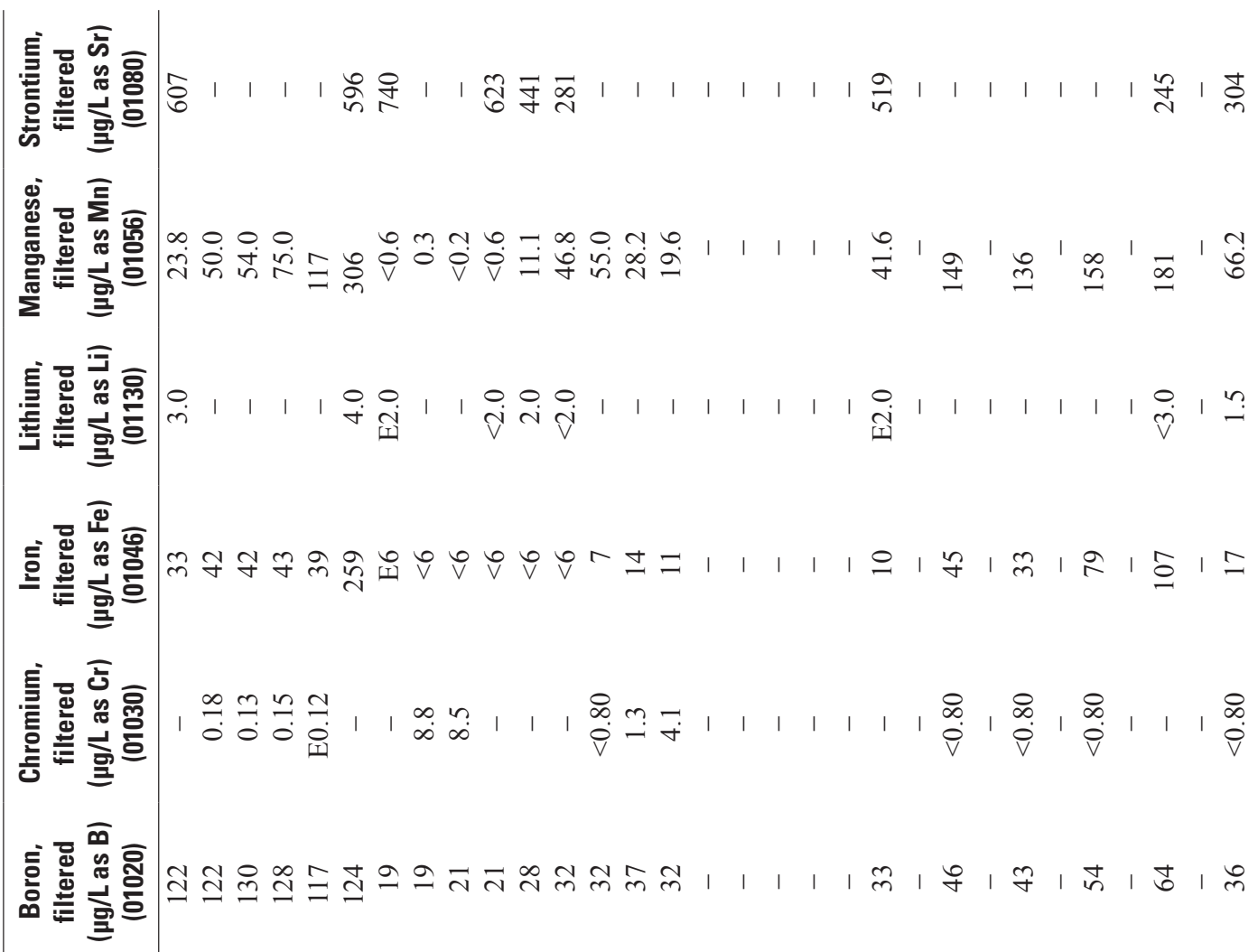

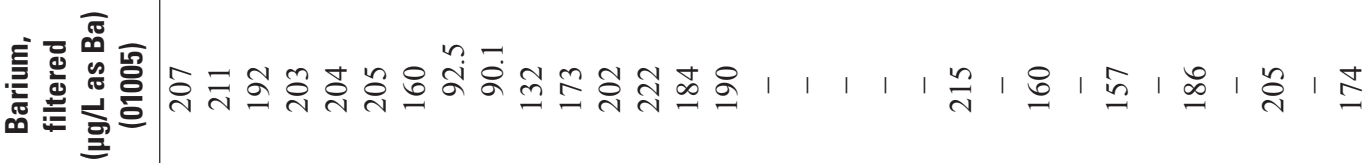

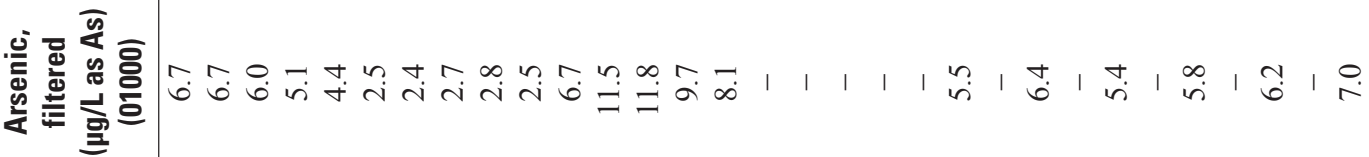

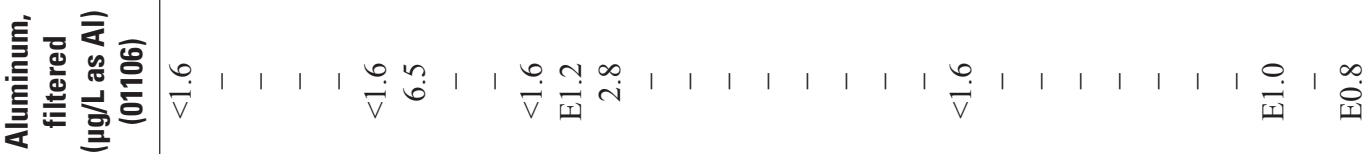

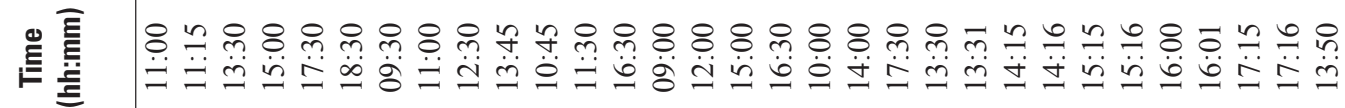

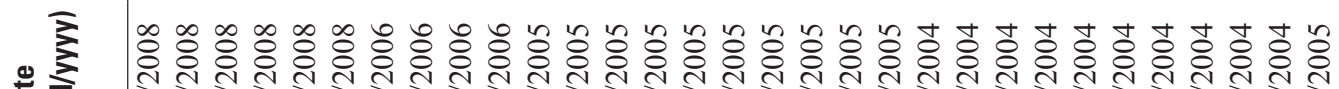
范

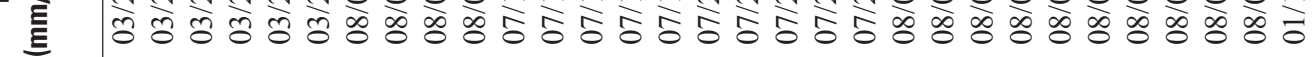

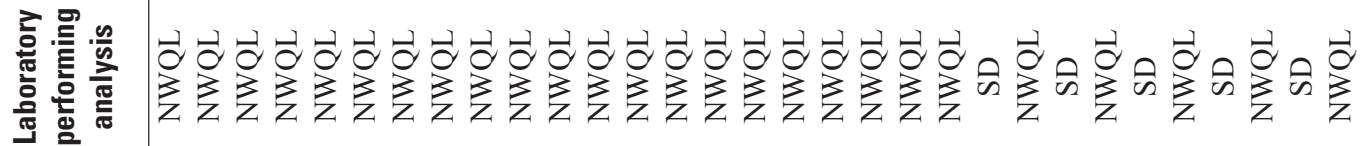

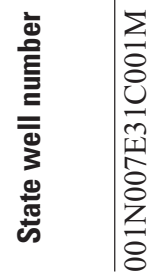

\begin{tabular}{|c|}
\hline$\underset{8}{\Sigma}$ \\
\hline
\end{tabular}

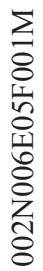




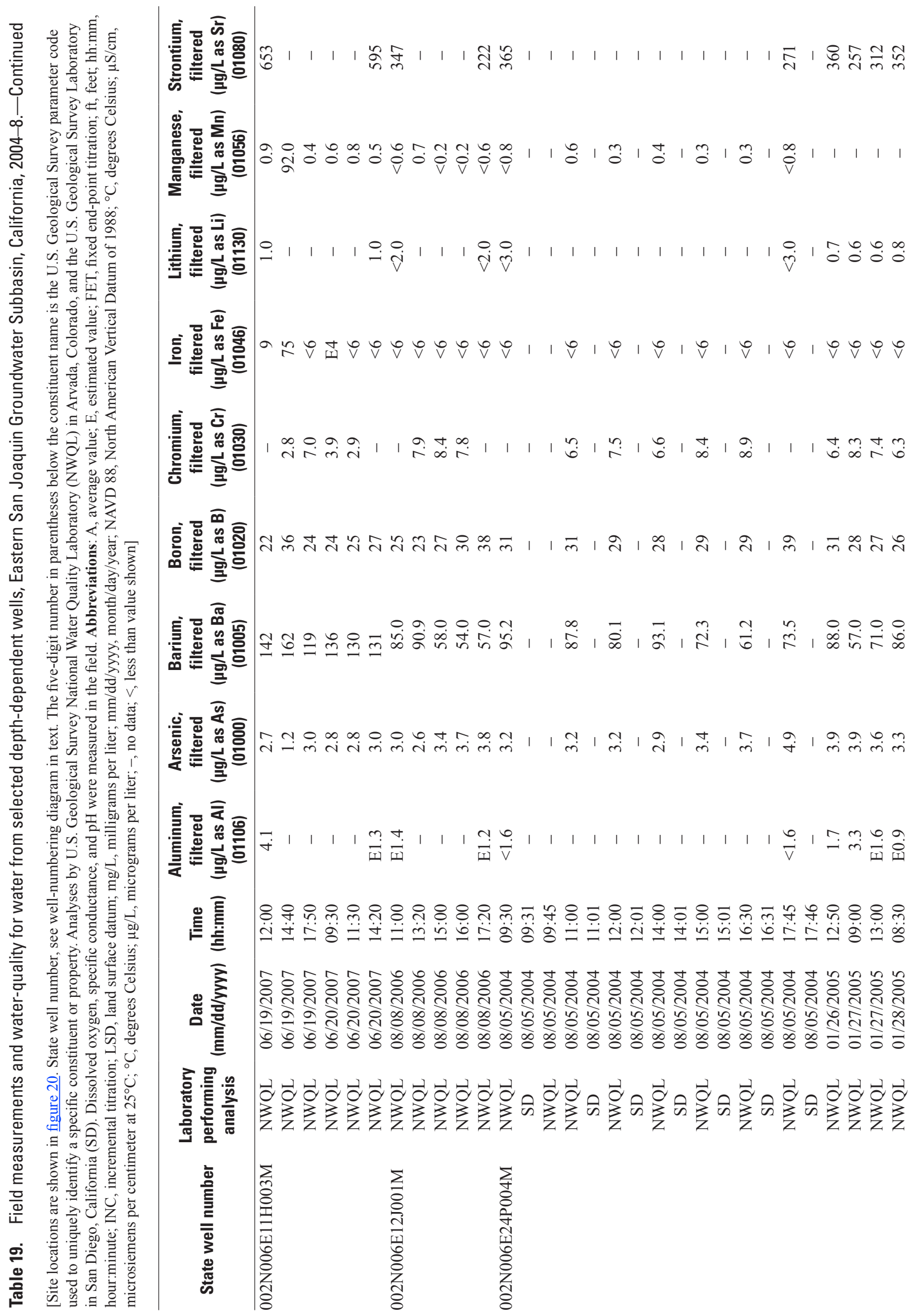




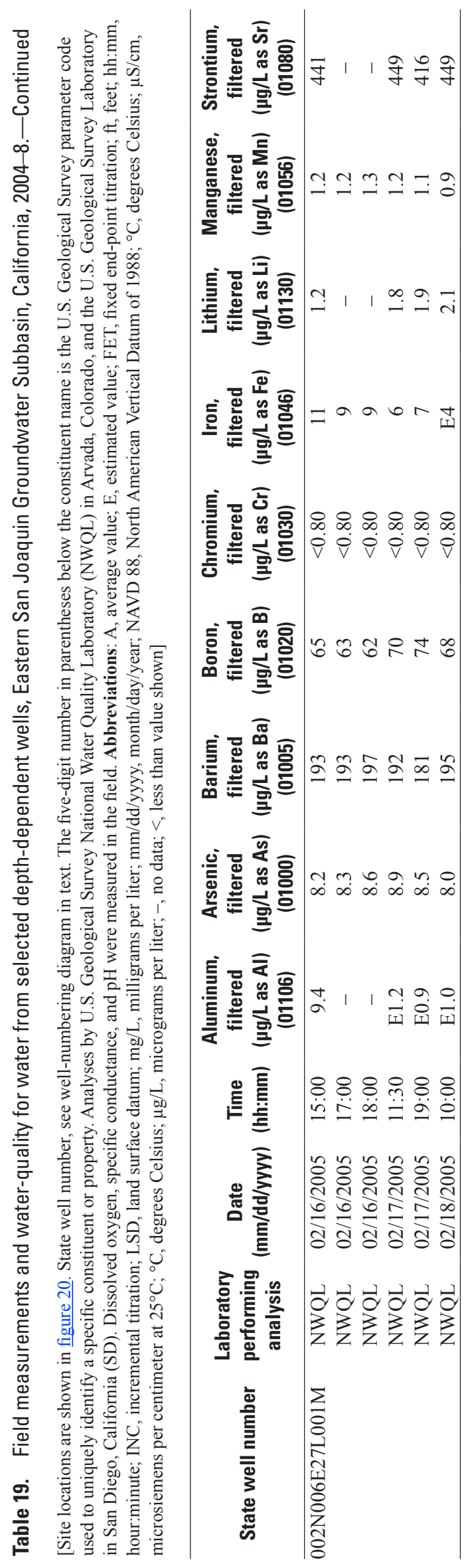



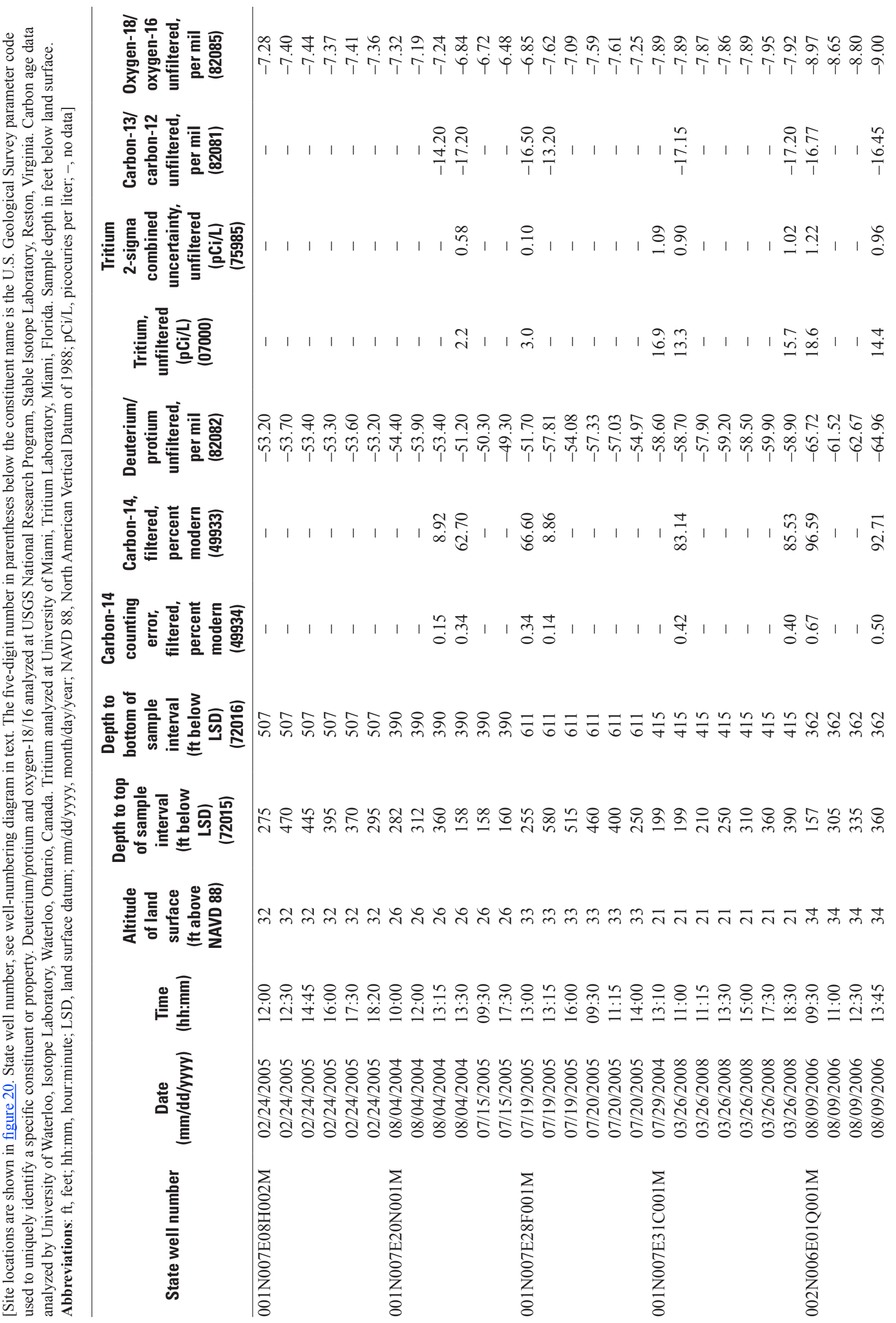


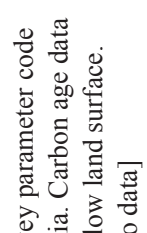

仓ั

㛃造

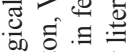

क⿺辶一兀

$8 \simeq$

㝘泀

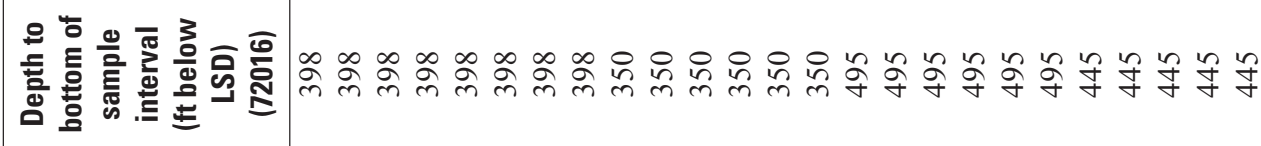

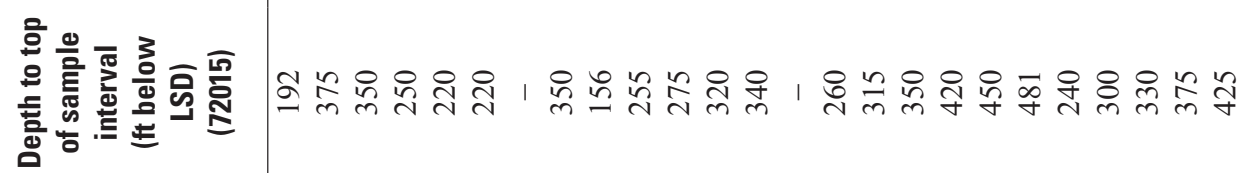

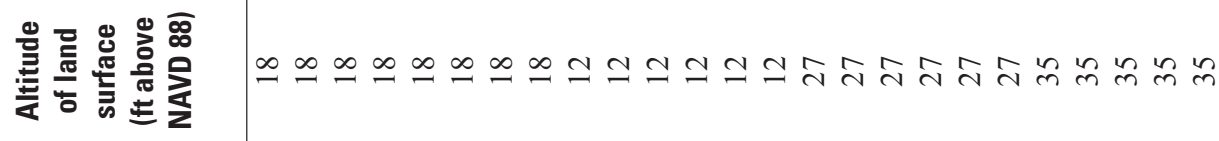

\begin{tabular}{|c|c|c|c|}
\hline & \multicolumn{3}{|c|}{ 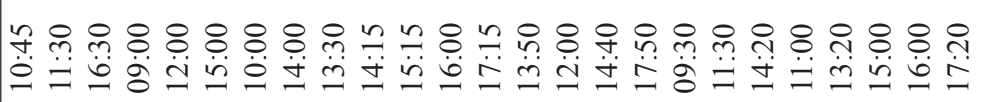 } \\
\hline 武 & 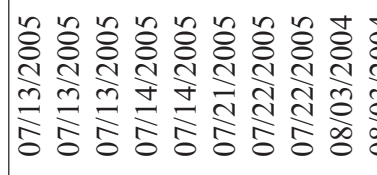 & $\frac{d}{b} \frac{N}{a}$ & 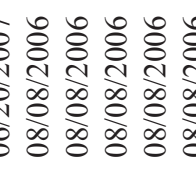 \\
\hline 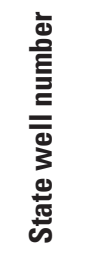 & 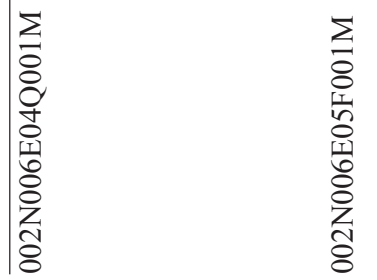 & 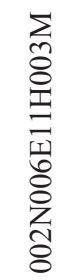 & 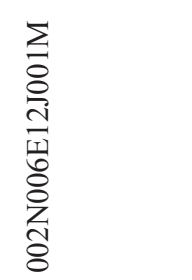 \\
\hline
\end{tabular}




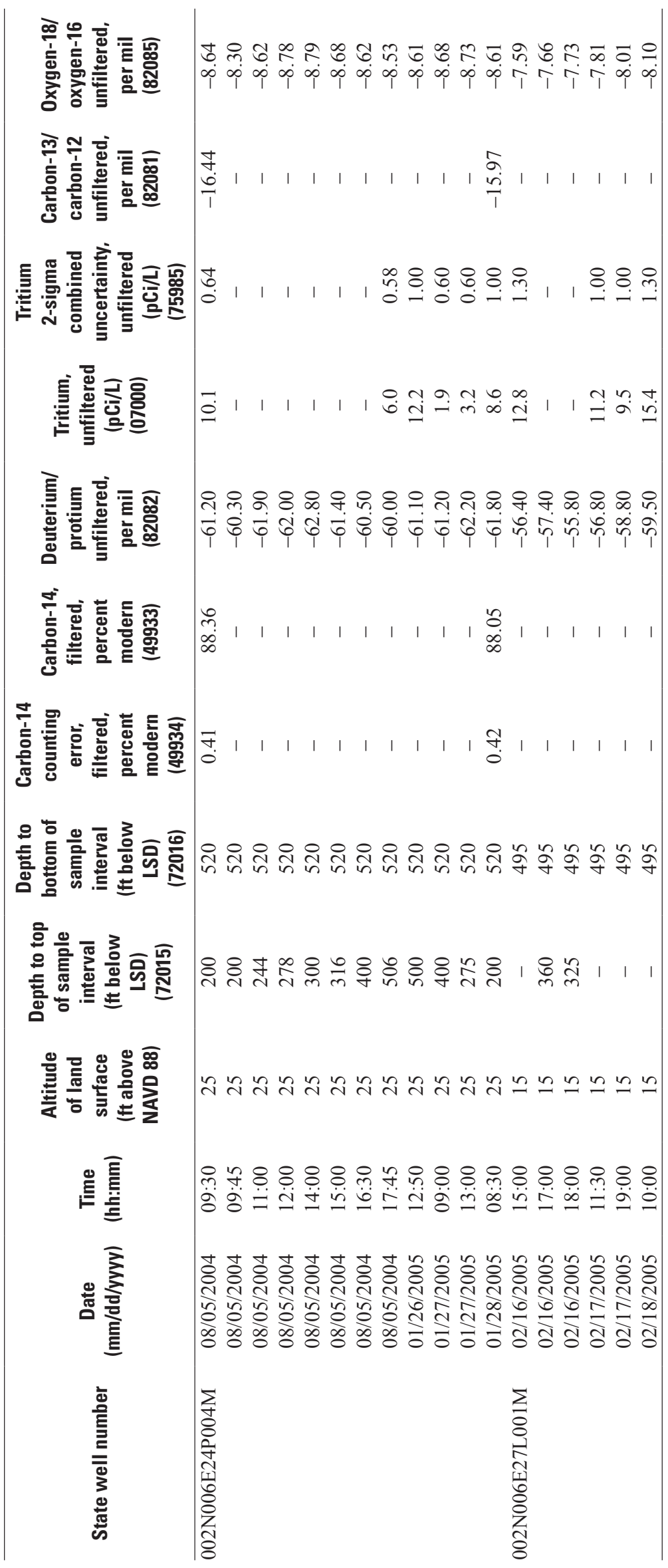


Table 21. Identification numbers and screen depths for depth-dependent wells, Eastern San Joaquin Groundwater Subbasin, California.

[State well number, see well-numbering diagram in text. Site locations are shown in figure 20. Abbreviations: ft, feet; LSD, land surface datum; NAVD 88, North American Vertical Datum of 1988; USGS ID, U.S. Geological Survey identification number: the unique number for each site in USGS National Water Information System (NWIS) database]

\begin{tabular}{lccccc}
\hline State well number & USGS ID & $\begin{array}{c}\text { Altitude of } \\
\text { land surface } \\
\text { (ft above } \\
\text { NAVD 88) }\end{array}$ & $\begin{array}{c}\text { Depth of well } \\
\text { (ft below LSD) }\end{array}$ & $\begin{array}{c}\text { Depth to top of } \\
\text { screen interval } \\
\text { (ft below LSD) }\end{array}$ & $\begin{array}{c}\text { Depth to bottom } \\
\text { of screen interval } \\
\text { (ft below LSD) }\end{array}$ \\
\hline 001N007E08H002M & 375701121132101 & 32 & 527 & 275 & 507 \\
001N007E20N001M & 375452121141401 & 26 & 410 & 158 & 390 \\
001N007E28F001M & 375429121124501 & 33 & 645 & 255 & 620 \\
001N007E31C001M & 375339121150301 & 21 & 425 & 199 & 415 \\
002N006E01Q001M & 380244121154901 & 34 & 380 & 157 & 362 \\
002N006E04Q001M & 380239121192401 & 18 & 408 & 192 & 398 \\
002N006E05F001M & 380302121203201 & 12 & 364 & 156 & 354 \\
002N006E11H003M & 380212121164601 & 27 & 500 & 260 & 495 \\
002N006E12J001M & 380201121153301 & 35 & 465 & 240 & 445 \\
002N006E24P004M & 380003121160701 & 25 & 540 & 200 & 520 \\
002N006E27L001M & 375919121182401 & 15 & 519 & 195 & 495 \\
\hline
\end{tabular}


Table 22. Selected dissolved ions and isotopes in pore water extracted by pressure from core material from selected multiple-well monitoring sites, Eastern San Joaquin Groundwater Subbasin, California.

[Site locations are shown in figure 2. State well number, see well-numbering diagram in text. The five-digit number in parentheses below the constituent name is the U.S. Geological Survey parameter code used to uniquely identify a specific constituent or property. Data analyzed by U.S. Geological Survey (USGS) National Water Quality Laboratory (NWQL) in Arvada, Colorado, Deuterium/protium and oxygen-18/16 analyzed at USGS National Research Program, Stable Isotope Laboratory, Reston, Virginia, and Specific conductance done at the U.S. Geological Survey Laboratory in San Diego, California. Sample depth in feet below land surface. Abbreviations: E, estimated value; ft, feet; hh:mm, hour:minute; LSD, land surface datum; mg/L, milligrams per liter; mm/dd/yyyy, month/ day/year; NAVD 88, North American Vertical Datum of 1988; $\mu \mathrm{S} / \mathrm{cm}$, microsiemens per centimeter at 25 degrees Celsius; $\mu \mathrm{g} / \mathrm{L}$, micrograms per liter; -, no data; $<$, less than value shown]

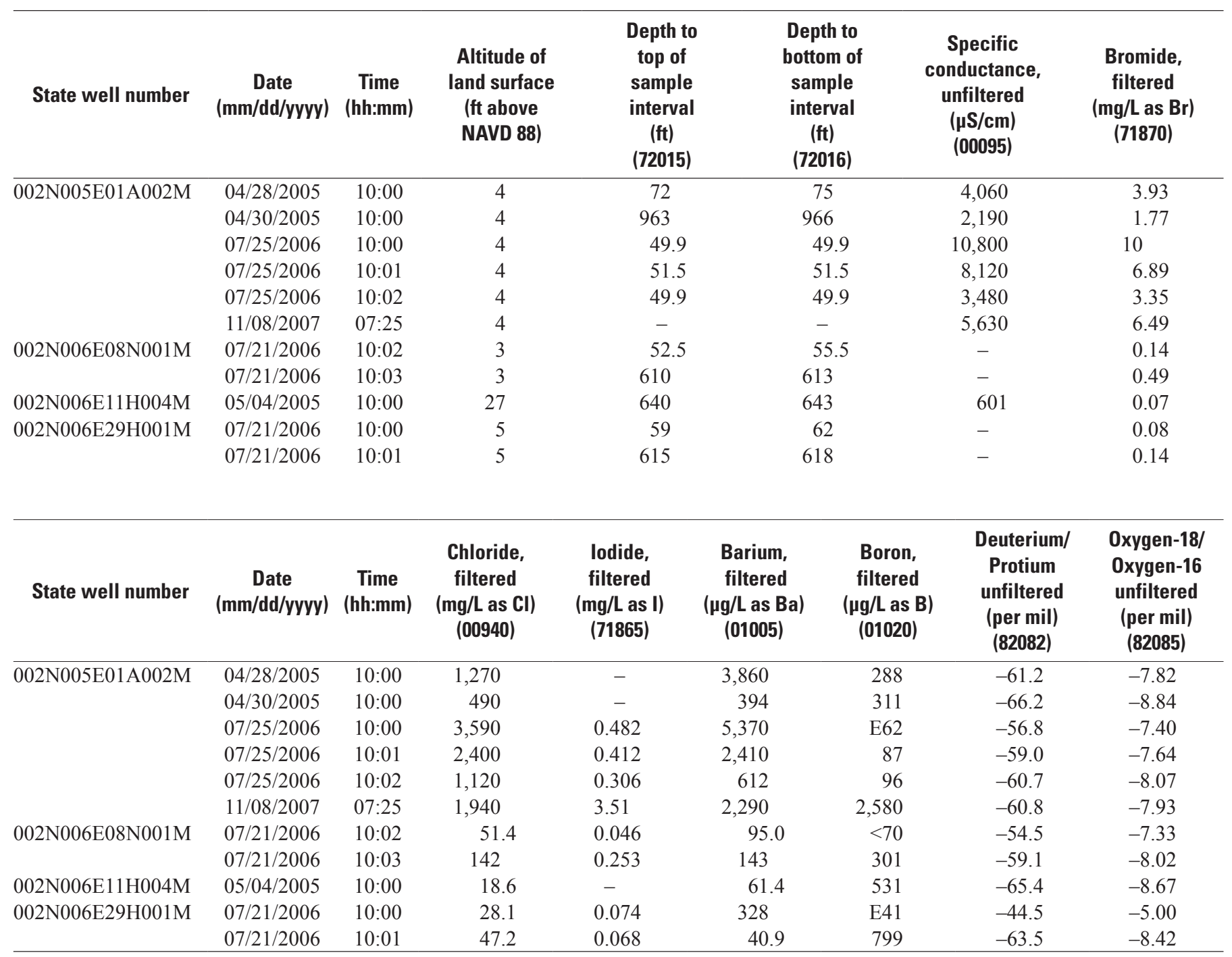




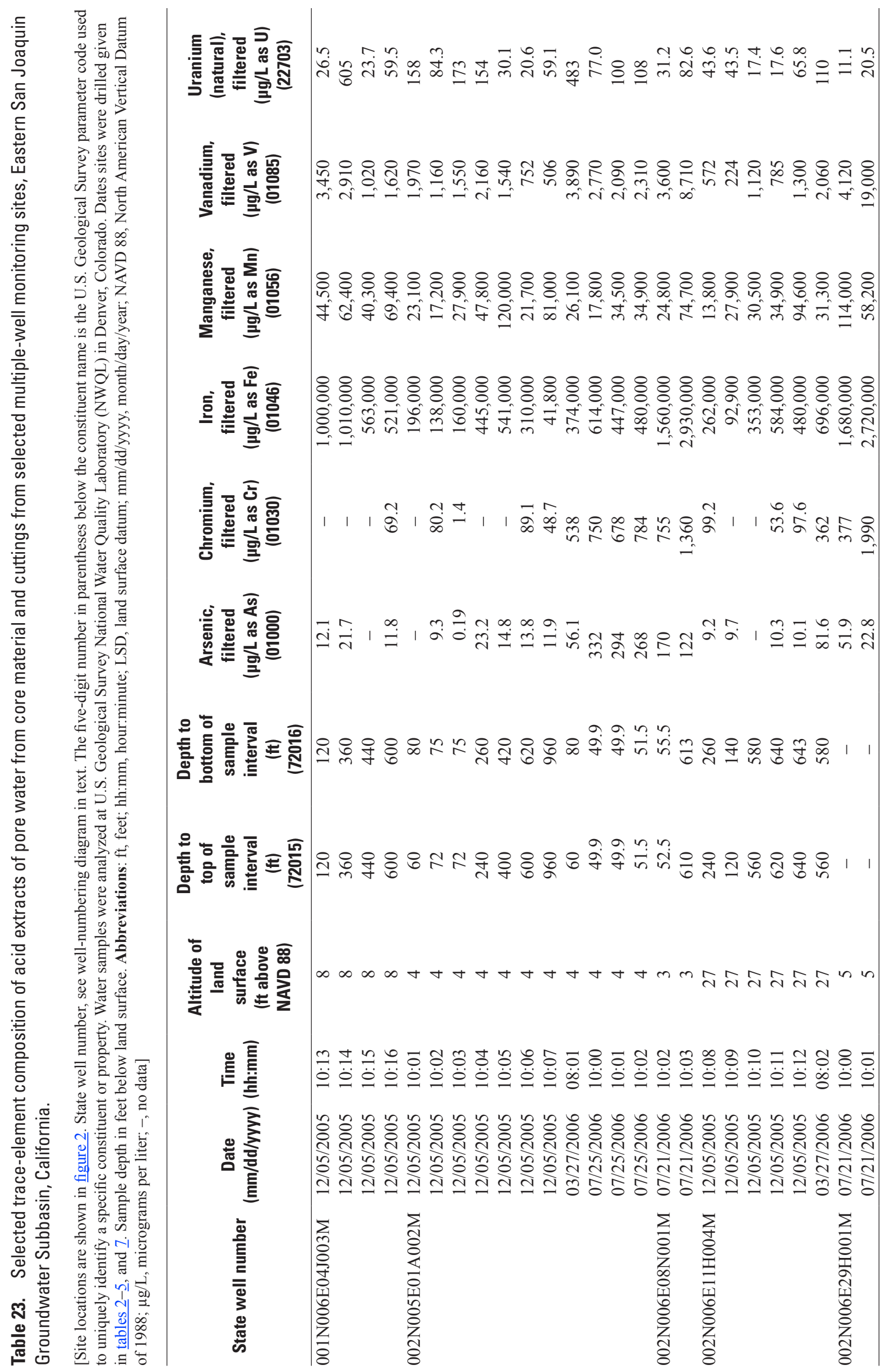




\section{References Cited}

Bennett, G.L., Belitz, Kenneth, and Milby-Dawson, B.J., 2006, California GAMA program: groundwater quality data in the Northern San Joaquin Basin study unit, 2005: U.S. Geological Survey Data Series 196, 122 p., available at http://pubs.er.usgs.gov/usgspubs/ds/ds196.

Beukens, R.P., 1992, Radiocarbon accelerator mass spectrometry, in Taylor, R.E., Long, A., and Kra, R.S., eds., Background, precision, and accuracy, radiocarbon after four decades: an Interdisciplinary perspective: New York, Springer-Verlag, p. 230-239.

Burow, K.R., Weissmann, G.S., Miller, R.D., and Placzek, Gary, 1997, Hydrogeologic facies characterization of an alluvial fan near Fresno, California, using geophysical techniques: U.S. Geological Survey Open-File Report 97-46, 15 p., available at http://pubs.er.usgs.gov/ usgspubs/ofr/ofr9746.

California Department of Water Resources, 1967, San Joaquin County investigation: Bulletin-146: Sacramento, California Department of Water Resources variously paged.

California Department of Water Resources, 2003, Hydrogeologic investigation in Stockton, California, May 2002: Sacramento, California Department of Water Resources, Central District, Division of Planning and Local Assistance, variously paged.

California Department of Water Resources, 2006, California's groundwater, San Joaquin Valley groundwater basin, Eastern San Joaquin subbasin-Bulletin 118: Sacramento, California Department of Water Resources, 6 p., accessed April 2012 at http://www.water.ca.gov/pubs/groundwater/ bulletin_118/basindescriptions/5-22.01.pdf.

CDM, Inc., 2001, San Joaquin County water management plan: phase 1-planning analysis and strategy: Sacramento, Calif., Camp, Dresser, and McKee, Inc., variously paged.

Century Geophysical Corp., 2008, User guide, slim hole induction tool model numbers 9510, 9511, and 9512: Tulsa, Okla., accessed February 15, 2008, at http://www.century-geo.info/dnn/EquipmentSales/ LoggingTools/9512LoggingTool.aspx.

Chao, T.T., and Sanzolone, R.F., 1989, Fractionation of soil selenium by sequential partial dissolution: Soil Science of America Journal, v. 53, no. 2, p. 385-392.

Coplen, T.B., 1994, Reporting of the stable hydrogen, carbon, and oxygen isotopic abundances: Pure and Applied Chemistry, v. 66, no. 2, p. 273-276.
Coplen, T.B., Wildman, J.D., and Chem, J., 1991, Improvements in the gaseous hydrogen-water equilibration technique for hydrogen isotope ratio analysis: Analytical Chemistry, v. 63, no. 9, p. 910-912.

Curtis, G.H., 1954, Mode of origin of pyroclastic debris in the Mehrten formation of the Sierra Nevada: University of California Publications in Geological Science, v. 29, no. 9, p. $453-502$.

Driscoll, F.G., 1986, Groundwater and wells (2nd ed.): Saint Paul, Minn., Johnson Filtration Systems, Inc., 1,089 p.

Epstein, S., and Mayeda, T., 1953, Variations of ${ }^{18} \mathrm{O}$ content of waters from natural sources: Geochimica et Cosmochimica Acta, v. 4, p. 213-224.

Faires, L.M., 1993, Methods of analysis by the U.S. Geological Survey National Water Quality Laboratorydetermination of metals in water by inductively coupled plasma-mass spectrometry: U.S. Geological Survey OpenFile Report 92-634, 28 p.

Fishman, M.J., 1993, Methods of analysis by the U.S. Geological Survey National Water Quality Laboratorydetermination of inorganic and organic constituents in water and fluvial sediments: U.S. Geological Survey Open-File Report 93-125, 217 p., available at http://pubs.er.usgs.gov/ usgspubs/ofr/ofr93125.

Fishman, M.J., and Friedman, L.C., 1989, Methods for determination of inorganic substances in water and fluvial sediments: U.S. Geological Survey Techniques of WaterResources Investigations, book 5, chap. A1, 545 p.

Folk, R.L., 1954, The distinction between grain size and mineral composition in sedimentary rock nomenclature: Journal of Geology, v. 62, no. 4, p. 344-359.

Gleason, J.D., Friedman, I., and Hanshaw, B.B., 1969, Extraction of dissolved carbonate species from natural water for carbon isotope analysis: U.S. Geological Survey Professional Paper 650-D, p. 248-250.

Gonfiantini, R., 1978, Standards for stable isotope measurements in natural compounds: Nature, v. 271, p. 534-536.

Hammermeister, D.P., Blout, D.O., and McDaniel, J.C., 1986, Drilling and coring methods that minimize the disturbance of cuttings, core, and rock formations in the unsaturated zone, Yucca Mountain, Nevada, in Proceedings of the NWWA Conference on Characterization and Monitoring of the Vadose (Unsaturated) Zone: Worthington, Ohio, National Water Well Association, p. 507-541.

Hill, A.D., 1990, Production logging - theoretical and interpretive elements, in Society of Petroleum Engineers Monograph: Richardson, Tex., Society of Petroleum Engineers, v. 14, 145 p. 
Izbicki, J.A., 2004, A small-diameter sample pump for collection of depth-dependent samples from production wells under pumping conditions: U.S. Geological Survey Fact Sheet 2004-3096, 2 p., available at http://pubs.er.usgs. gov/usgspubs/fs/fs20043096.

Izbicki, J.A., Ball, J.W., Bullen, T.D., and Sutley, S.J., 2008, Chromium, chromium isotopes and selected trace elements, western Mojave Desert, USA: Applied Geochemistry, v. 23, no. 5, p. 1325-1352.

Izbicki, J.A., Christensen, A.H., Hanson, R.T., Martin, Peter, Crawford, S.M., and Smith, G.A., 1999, U.S. Geological Survey combined well-bore flow and depth-dependent water sampler: U.S. Geological Survey Fact Sheet 196-99, 2 p., available at http://pubs.er.usgs.gov/usgspubs/fs/fs19699.

Izbicki, J.A., Christensen, A.H., Newhouse, M.W., and Aiken, G.R., 2005, Inorganic, isotopic, and organic composition of high-chloride water from wells in a coastal southern California aquifer: Applied Geochemistry, v. 20, no. 8, p. 1496-1517.

Izbicki, J.A., Metzger, L.F., McPherson, K.R., Everett, R.R., and Bennett, G.L., 2006, Sources of high-chloride water to wells, Eastern San Joaquin Groundwater Subbasin, California: U.S. Geological Survey Open-File Report 20061309,8 p., available at http://pubs.er.usgs.gov/usgspubs/ofr/ ofr20061309.

Izbicki, J.A., Stamos, C.L., Metzger, L.F., Halford, K.J., Kulp, T.R., and Bennett, G.L., 2008, Source, distribution, and management of arsenic in water from wells, Eastern San Joaquin Groundwater Subbasin, California: U.S. Geological Survey Open-File Report 2008-1272, 8 p., available at http://pubs.er.usgs.gov/usgspubs/ofr/ofr20081272.

Jones, S.R., and Garbarino, J.R., 1999, Methods of analysis by the U.S. Geological Survey National Water Quality Laboratory - determination of arsenic and selenium in water and sediment by graphite furnace-atomic absorption spectrometry: U.S. Geological Survey Open-File Report 98-639, 39 p.

Jurgens, B.C., Burow, K.R., Dalgish, B.A., and Shelton, J.L., 2008, Hydrogeology, water chemistry, and factors affecting the transport of contaminants in the zone of contribution of a public-supply well in Modesto, Eastern San Joaquin Valley, California: U.S. Geological Survey Scientific Investigations Report 2008-5156, 78 p., available at http:// pubs.er.usgs.gov/usgspubs/sir/sir20085156.

Keys, W.S., 1990, Borehole geophysics applied to groundwater investigations: U.S. Geological Survey Techniques of Water-Resources Investigations, book 2, chap. E2, 150 p.
Keys, W.S., and MacCary, L.M., 1983, Application of borehole geophysics to water-resources investigations:. U.S. Geological Survey Techniques of Water Resources Investigations, book 2, chap. E1, $126 \mathrm{p}$.

Manheim, F.T., Brooks, E.G., and William, J.W., 1994, Description of a hydraulic sediment squeezer: U.S. Geological Survey Open-File Report 94-584, 39 p.

McNeil, J.D., Bosnar, M., and Snelgrove, F.B., 1990, Resolution of an electromagnetic borehole conductivity logger for geotechnical and ground water applications: Mississauga, Ontario, Geonics Ltd., Technical Note 25, p. $25-28$.

Mendenhall, W.C., 1908, Ground waters of the San Joaquin Valley, California: U.S. Geological Survey Water-Supply Paper 222, $52 \mathrm{p}$.

Montgomery Watson, Inc., 2000, Salinity assessment and monitoring well network evaluation: Sacramento, Calif., San Joaquin County Flood Control and Water Conservation District, file no. 1510285.1, variously paged.

Munsell Color, 1975, Munsell soil color charts: Baltimore, Md., Munsell Color, Inc.

Munsell Color, 1994, Munsell soil color charts: Baltimore, Md., Munsell Color, Inc.

National Research Council, 1947, Report of the subcommittee on sediment terminology: American Geophysical Union Transactions, v. 28, no. 6, p. 936-938.

Newhouse, M.W., Izbicki, J.A., and Smith, G.A., 2005, Comparison of velocity-log data collected using impeller and electromagnetic flowmeters: Ground Water, v. 43, no. 3, p. 434-438.

Northeastern San Joaquin County Groundwater Banking Authority, 2004, Eastern San Joaquin Basin groundwater management plan: Stockton, Calif., Northeastern San Joaquin Groundwater Banking Authority, variously paged.

Ostlund, H.G., and Warner, E., 1962, Electrolytic enrichment of tritium and deuterium for natural tritium measurements, in Tritium in the physical and biological sciences: Vienna, International Atomic Energy Agency, v. 1, p. 96-104.

Paillet, F.L., 2000, Flow logging in difficult boreholesmaking the best of a bad deal, in International Symposium on Borehole Geophysics for Minerals, Geotechnical, and Groundwater Applications, 7th, Denver, Colo., 2000, Proceedings: Houston, The Minerals and Geotechnical Logging Society, a Chapter at Large of the Society of Professional Well Log Analysts, p. 125-135. 
Patton, C.J., and Truitt, E.P., 1992, Methods of analysis by the U.S. Geological Survey National Water Quality Laboratory - determination of total phosphorus by a Kjeldahl digestion method and an automated colorimetric finish that includes dialysis: U.S. Geological Survey Open-File Report 92-146, 39 p.

Piper, A.M., Gale, H.S., Thomas, H.E., and Robinson, T.W., 1939, Geology and groundwater hydrology of the Mokelumne area, California: U.S. Geological Survey Water-Supply Paper 780, 270 p.

Schlumberger, 1972, Log interpretation, volume I-principles: New York, Schlumberger Limited, 112 p.

Soil Conservation Service, 1992, Soil survey of San Joaquin County, California: U.S. Department of Agriculture, 480 p.

Struzeski, T.M., DeGiacomo, W.J., and Zayhowski, E.J., 1996, Methods of analysis by the U.S. Geological Survey National Water Quality Laboratory-determination of total phosphorous by a Kjeldahl digestion method and an automated colorimetric finish that includes dialysis: U.S. Geological Survey Open-File Report 96-149, 17 p.

Stuiver, M., and Polach, H.A., 1977, Discussion: reporting of ${ }^{14} \mathrm{C}$ data: Radiocarbon, v. 19 , no. 3, p. 355-363.

Thatcher, L.L., Janzer, V.J., and Edwards, K.W., 1977, Methods for determination of radioactive substances in water and fluvial sediments: U.S. Geological Survey Techniques of Water-Resources, book 5, chap. A5, 95 p.
U.S. Environmental Protection Agency, 2006, Ground water and drinking water-list of drinking water contaminants and MCL's: accessed August 15, 2006, at http://www.epa. gov/safewater/mcl.html\#sec.

U.S. Geological Survey, variously dated, National field manual for the collection of water-quality data: Techniques of Water-Resources Investigations, book 9, chap. A1-A9, variously paged, available at http://pubs.water.usgs.gov/ twri9A.

Wigley, T.M.L., and Muller, A.B., 1981, Fractionation corrections in radiocarbon dating: Radiocarbon, v. 23, p. 173-190.

Wilde, F.D., ed., 2001, Field measurements, in U.S. Geological Survey, National field manual for the collection of water-quality data: Techniques of Water-Resources Investigations book 9, chap. A6, variously paged, available at http://water.usgs.gov/owq/FieldManual/Chapter6/Ch6 contents.html.

Williams, J.H., Lapham, W.W., and Barringer, T.H., 1993, Application of electromagnetic logging to contamination investigations in glacial sand-and-gravel aquifers: Ground Water Monitoring \& Remediation, v. 13, no. 3, p. 129-138.

Young, S.C., and Pearson, H.S., 1995, The electromagnetic borehole flowmeter-description and applications: Ground Water Monitoring and Remediation Review, v. 15, no. 4, p.138-146. 
Publishing support provided by the U.S. Geological Survey Science

Publishing Network, Sacramento and Tacoma Publishing Service Centers

For more information concerning the research in this report, contact the Director, California Water Science Center

U.S. Geological Survey

6000 J Street, Placer Hall

Sacramento, California 95819

http://ca.water.usgs.gov 
